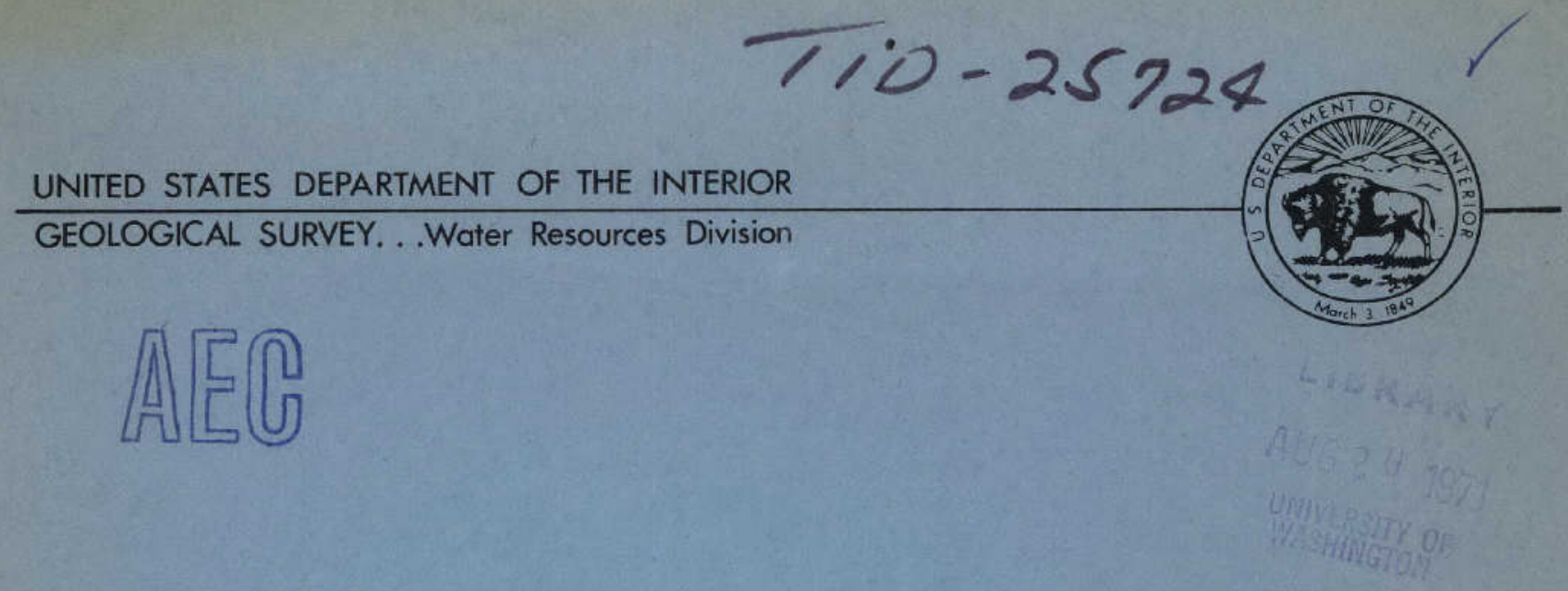

\title{
$\biguplus$ Distribution of Radionuclides in Bottom Sediments of the Columbia River Estuary
}
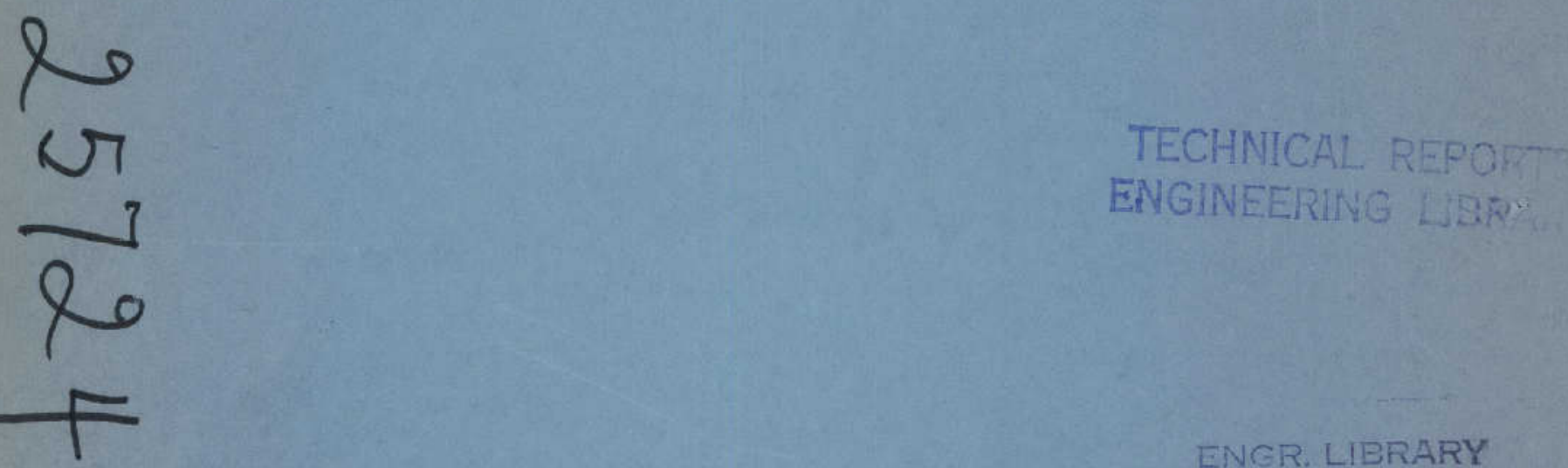

Prepared in Cooperation with the United States Atomic Energy Commission 



\section{UNITED STATES \\ DEPARTMENT OF THE INTERIOR \\ GEOLOGICAL SURVEY \\ Water Resources Division}

DISTRIBUTION OF RADIONUCLIDES IN BOTTOM SEDIMENTS OF THE COLUMBIA RIVER ESTUARY

By D. W. Hubbe 11 and J. L. Glenn

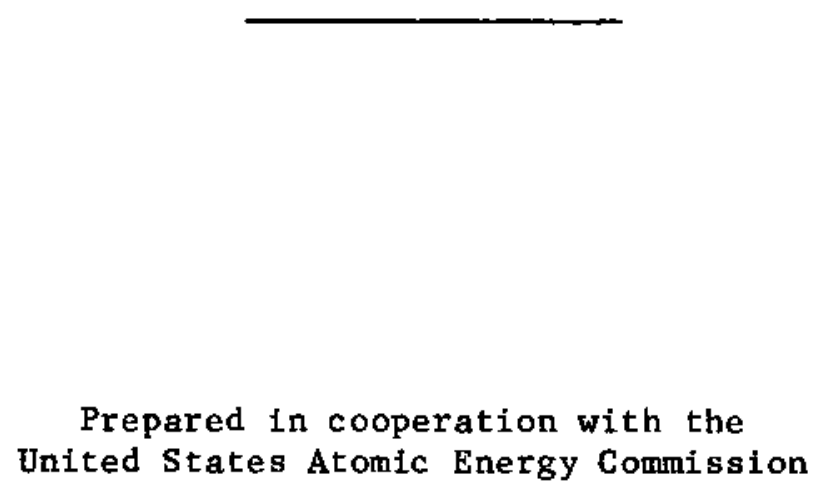

OPEN-FILE REPORT

Portland, Oregon 1971 

Abstract-1- 1

Introduction and acknowledgments-1 5

The Columbia River estuary-- 8

Description of the estuary- 8

Radionuclides in the Columbia River-a 11

Equipment, data collection, and analytical techniques-1....... 14

Textural characteristics of bottom sediments- 23

Surficial sediment-1.. 23

Cores:-1.20 40

Radioactivity in bottom sediments 50

Gross-gamma radioactivity- 50

Radionuclides in surficial sediment-59

Radionuclides in cores- 70

Sediment composition and radionuclide content-- 74

Generalized qualitative description of the distribution of

radionuclides in the estuary- 84

Radionuclide inventory- 87

Aspects of sediment transport in the estuary- 97

Retention of fine sediment in the estuary-- 98

Radionuclide concentrations and sediment transport-- 102

Rates of deposition-106

Conclusions-1

Literature cited-1-0 117

Appendixes-10 122 


\section{ILLUSTRATIONS}

Page

Plate 1. Location of sampling and measuring sites landward

from river mile 31-net

2. Location of sampling and measuring sites seaward

from river mile $31 \ldots$ In pocket

Figure 1. Map of Columbia River estuary-- 6

2-5. Photographs showing:

2-3. Scinti1lation-detector and sled--16

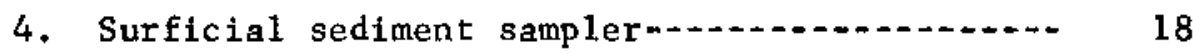

5. Core sampler-19

6. Diagram showing sand:silt:clay relations for

surficial sediment samples-1-0 24

7-13. Bar graphs showing radioactivity and texture

at surficial sediment sample locations:

7. Cross sections at river miles 2 and 6-------- 26

8. Cross sections at river miles 14 and 18-a..- 27

9. Cross section at river mile $23-28$

10. Cross section at river mile 27-- 29

11. Cross sections at river miles 31 and $38 \ldots \ldots \ldots$

12. Cross sections at river miles 42,47 ,

and $50-\ldots$

13. Cross sections at river miles 54,59 , and $64-\ldots$

14. Graph of average textural characteristics of surficial samples in geomorphic classes at cross sections along the estuary-no 35 


\section{ILLUSTRATIONS}

Page

Figure 15. Photograph of longitudinal sections of cores---1-- 44

16. Diagram of textural characteristics of cores------- 46

17. Graph showing vertical distribution of

textural characteristics in cores-an 49

18. Graphs comparing laboratory and in situ

gross gamma count rates and radionuclide

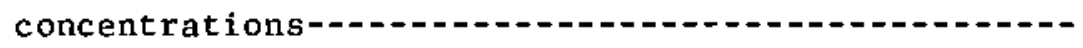

19. Graph of variation of in situ count rate with

total concentration of measured radionuclides

in surficial sediment--n-to-

20. Graph of relation between in situ gross gamma

count rate and total amount of measured

radionuclides in upper 8 inches of streambed------

21. Graph of relations between in situ gross gamma

count rates and amounts of ${ }^{65} \mathrm{Zn}$ and ${ }^{51} \mathrm{Cr}$ in

upper 8 inches of streambed-c-

22. Histogram of frequency distribution of in situ

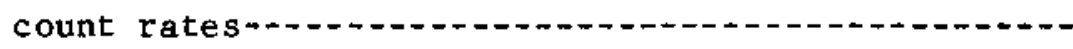

23. Graph of relations between ${ }^{51} \mathrm{Cr}$ and ${ }^{65} \mathrm{Zn}$ concentrations and specific surface of surficial sediment samples obtained in October 1964 and June I965

24. Bar graph showing stratigraphic distribution of radionuclide concentrations and texture in cores 


\section{ILLUSTRATIONS}

Page

Figure 25. Graph of variation of total concentration of measured radionuclides in surficial sediment with textural statistics-o-n

26. Graph showing variation of ${ }^{65} \mathrm{Zn}$ concentration in surficial sediment with specific surface------ 78

27. Graph of variation of ${ }^{65} \mathrm{Zn}$ concentration in surficial sediment with mean particle size-------

28. Graph showing longitudinal attenuation of

$65 \mathrm{Zn}$ concentration associated with

individual size separates-0.-

29. Graph of cumulative distribution of amounts

of total measured radionuclides, ${ }^{65} \mathrm{Zn}$, and

${ }^{51} \mathrm{Cr}$ in bed of estuary

30. Graph of vertical distribution of ${ }^{65} \mathrm{Zn} /{ }^{60} \mathrm{Co}$ ratio in core c373

Va. Graph of specific weight of sediment versus median particle sizem-n-c-

TABLES

Page

Table 1. Average values of $M_{\Phi}, \sigma_{\Phi}$, and $\alpha_{1 \Phi}$ for various geomorphic classes at cross sections in the

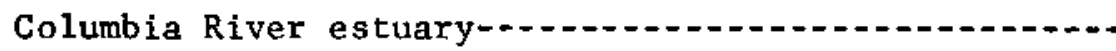


Table 2. Summary of textura1 statistics of surficial sediment samples grouped according to geo-

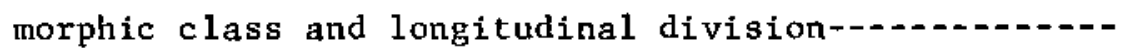

3. Qualitative aspects of Columbia River estuary

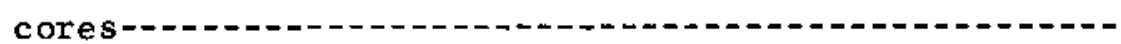

4. Sumary of average textural characteristics of cores from the Columbia River estuary--.-- 48

5. Average in situ gross gamma radioactivity at sample sites within each geomorphic class in each cross section-1.t.-

6. Comparison of average values of several size statistics and in situ gross gamma count rates for different sample groups at each estuary cross section-1...

7. Summary of measured radionuclides in surficial

sediment samples from estuary cross sections-.-.-.--

8. Variation of measured radionuclides in surficial

sediment samples with geomorphic class and

longitudinal division-1...

9. Summary of the stratigraphic distribution of measured radionuclides (excluding $40_{K}$ ) in cores from the Columbia River estuary--.-

10. Inventory of measured radionuclides in the Columbia River estuary--...

11. Computation of fraction of fine sediment (P) retained in the Columbia River estuary--..- 


\section{APPENDIXES}

Page

Appendix I. Particle-size statistics of surficial sediment

from the Columbia River estuary-a. 122

II. Particle-size statistics of selected segments

of cores from the Columbia River estuary---.-.-. 124

III. Measured radionuclide concentrations and

computed totals and ratios of radionuclides

in surficial sediment from the Columbia River

estuary-m-non 126

IV. Measured radionuclide concentrations and

computed totals and ratios of radionuclides

in selected segments of cores from the

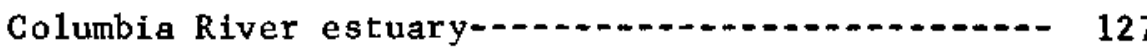

v. Determination of the amount of radionuclides

per unit area below the bed surface-131

VI. Explanation of variables used in the computation

of the fraction of fine sediment retained in

the estuary-ne- 134 


\title{
DISTRIBUTION OF RADIONUCLIDES IN BOTTOM SEDIMENTS OF THE
}

COLUMBIA RIVER ESTUARY

By D. W. Hubbe 11 and J. L. Glenn

\begin{abstract}
Radionuclides produced primarily by neutron activation of naturally occurring stable elements and chemical additives in nuclear-reactor coolant water are discharged into the Columbia River at the Hanford Reservation of the United States Atomic Energy Commission. In the river, the radionuclides associate with sediment and biota or remain in solution and subsequently are distributed downstream throughout the river system and the Columbia River estuary to the Pacific Ocean. To provide information on the distribution of radioactivity in the estuary, the physical and radiological character of the streambed was investigated in 1965 . Gross-gamma radiation was measured in situ and surficial samples and cores were obtained with specially designed equipment at 14 cross sections between Longview, Wash., near Columbia River mile 65.8, and the estuary mouth.

To facilitate data interpretation, the estuary is divided into geomorphic classes termed "channels," "slopes," and "flats" and into longitudinal divisions called "fluvial," "transitional," and "marine."
\end{abstract}


Grouping data obtained within the same class and division improves correlations significantly but additional classes are necessary.

In situ gross+gamma radiation varies over a seventyfold range and generally correlates with the total concentration of individually measured radionuclides in surficial samples. The most abundant radionuclides

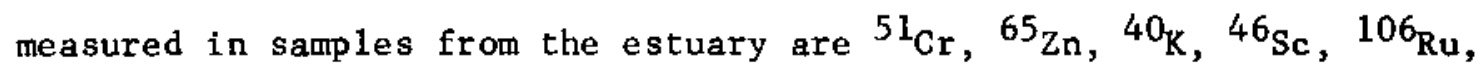
${ }^{54} \mathrm{Mn},{ }^{60} \mathrm{Co}$, and ${ }^{95} \mathrm{Zr}-{ }^{95} \mathrm{Nb}$. Concentrations of ${ }^{51} \mathrm{Cr}$ and ${ }^{65} \mathrm{Zn}$ in surficial sediment are approximately 6.2 and 2.2 times, respectively, greater than the concentration of naturally occurring ${ }^{40} \mathrm{k}$, which averages about 14 picocuries per gram of sediment; the other measured radionuclides are substantially less abundant. Radionuclide concentrations vary greatly from place to place, and even when samples in common geomorphic classes and longitudinal divisions are grouped, standard deviations generally are so large that positive conclusions relative to changes in individual radionuclide concentrations along the estuary cannot be made with confidence. Chromium-51, however, appears to increase relative to ${ }^{65} \mathrm{Zn}$ toward the mouth of the estuary, and radionuclide concentrations are generally higher on slopes and flats than in channels.

The stratigraphic distribution of radionuclides also varies considerably. Radionuclides tend to be distributed to the greatest depths in channels and on slopes and may extend more than 60 Inches below the bed surface. However, on the average, 66 percent of the total amount of measured radionuclides (excluding ${ }^{40} \mathrm{~K}$ ) is contained in the upper 8 inches of the streambed. Ordinarily, highest concentrations are at the surface or a few inches below. The total amount of measured radioactivity (excluding $40_{K}$ ) in the sediment column beneath the bed surface ranges from about 0.05 to 15 microcuries per square foot. 
In the estuary as a whole, sediments in the channels are coarsest, sediments on the flats are finest and have the most positively skewed distributions, and sediments on slopes are intermediate in size and have the least skewed textural distributions. Within each longitudinal division these same trends exist; however, channel sediments are finest in the transition division and coarsest in the fluvial division. Sediments on slopes tend to have the same textural characteristics throughout the estuary but on flats they are finest in the fluvial and marine divisions. Cores indicate that estuary sediments are stratified, a thin fine-grained layer caps many cores that otherwise are essentially sand, and variations in sediment texture with depth are large at some locations. Sediment composition influences the level of radioactivity to a high degree. The total concentration of measured radionuclides (excludIng $40 \mathrm{~K}$ ) Increases as sediment decreases in size and becomes less well sorted, and as the textural distribution of the sediment becomes more skewed toward fine materia1. Computations based on relations between mean particle size and radioactivity in surficial sediment samples indicate that ${ }^{65} \mathrm{Zn}$ concentrations associated with individual size separates decrease in a downstream direction.

An inventory of the amounts of radionuclides in the bed was computed using maps that divide the estuary into nine areas in which the level of radioactivity near the surface and the stratigraphic distribution of radionuclides are similar. In situ radioactivity and general relations among radionuclide content, geomorphic expression, and sediment composition were used in preparing the maps. The inventory shows that at the time of the survey (June 1965) the amount of measured radionuclides (excluding ${ }^{40} \mathrm{~K}$ ) was 8,700 curies and consisted of 5,300 curies of ${ }^{51} \mathrm{Cr}$, 
2,100 curies of ${ }^{65} \mathrm{Zn}$, and 1,300 curies of other activation products and fallout. The estuary appears to contain about one quarter of all the radionuclides in the reservoir (river, estuary, and ocean) below Vancouver, Wash. Approximately 15, 48, and 37 percent of the total amount of measured radionuclides is in the marine, transition, and fluvial divisions, respectively, and channels, slopes, and flats con$\operatorname{tain} 23,36$, and 41 percent of the total amount, respectively. The distributions of ${ }^{65} \mathrm{Zn}$ and ${ }^{51} \mathrm{Cr}$ are about the same as the distribution of total measured radionuclides except that, proportionately, slightly more ${ }^{65} \mathrm{Zn}$ is in the transition division.

Within the context of simplifying assumptions, the amount of ${ }^{65} \mathrm{Zn}$ in the estuary and ${ }^{65} \mathrm{Zn}$ transport rates at Vancouver were used in a mass-balance equation to estimate the percent of fine sediment (finer than 62 microns) retained in the estuary. The calculations indicate that on an annual basis, about 30 percent of the fine sediment that enters the estuary may be retained there. Mean particle velocities, computed from the longitudinal attenuation of ${ }^{65} \mathrm{Zn}$ concentrations and ${ }^{65} \mathrm{Zn} /{ }^{60} \mathrm{Co}$ ratios, appear to be several times too high. This suggests that factors other than decay influence the concentration of radionuclides in surficial sediment. Alternating erosion and deposition, presumed to occur at most core sampling sites, precluded computations of meaningful deposition rates from changes in radionuclide ratios with depth; however, the rate determined for one core collected in an area where fine sediment may have been depositing more or less continuously was 3.4 inches per year.

This study indicates that geomorphic expression and sediment composition can be combined with a knowledge of the character of actual or 
contemplated radioactive wastes to predict the probable spatial distributions of radioactivity in estuaries.

\section{INTRODUCTION AND ACKNOWLEDGMENTS}

The Columbia River estuary serves as a repository for radionuclides derived partly from nuclear fallout throughout the Columbia River drainage basin and partly from low-leve1 radioactive wastes discharged into the river at the U.S. Atomic Energy Commission's Hanford Reservation near Richland, Wash. (fig. 1). The low-level wastes, which are by far the most important source, are produced primarily by neutron activation of chemical constituents in treated Columbia River water that is used to cool the nuclear reactors at the Reservation. Much of the waste decays within a relatively short time (Foster, 1964); however, there are detectable amounts of longer-lived radionuclides. Once radionuclides are discharged into the river they may remain in solution or become associated with sediment or biota. Regardless of their immediate fate, the radionuclides subsequently are dispersed and transported downstream. Mainly as a result of uptake and transport by sediment, radionuclides become distributed throughout the streambed to the Pacific Ocean. General levels of radionuclide content within the body of the flow have been monitored at various locations along the river by Hanford radiological health groups and by Washington and Oregon State agencies since the outset of reactor operations in 1944. However, investigations dealing with phenomenological aspects of radioactivity in the environment initially were confined mainly to reaches of the river in the vicinity of the Hanford Reservation.

In 1962, the Water Resources Division of the U.S. Geological Survey, in cooperation with the U.S. Atomic Energy Commission, undertook a detailed 


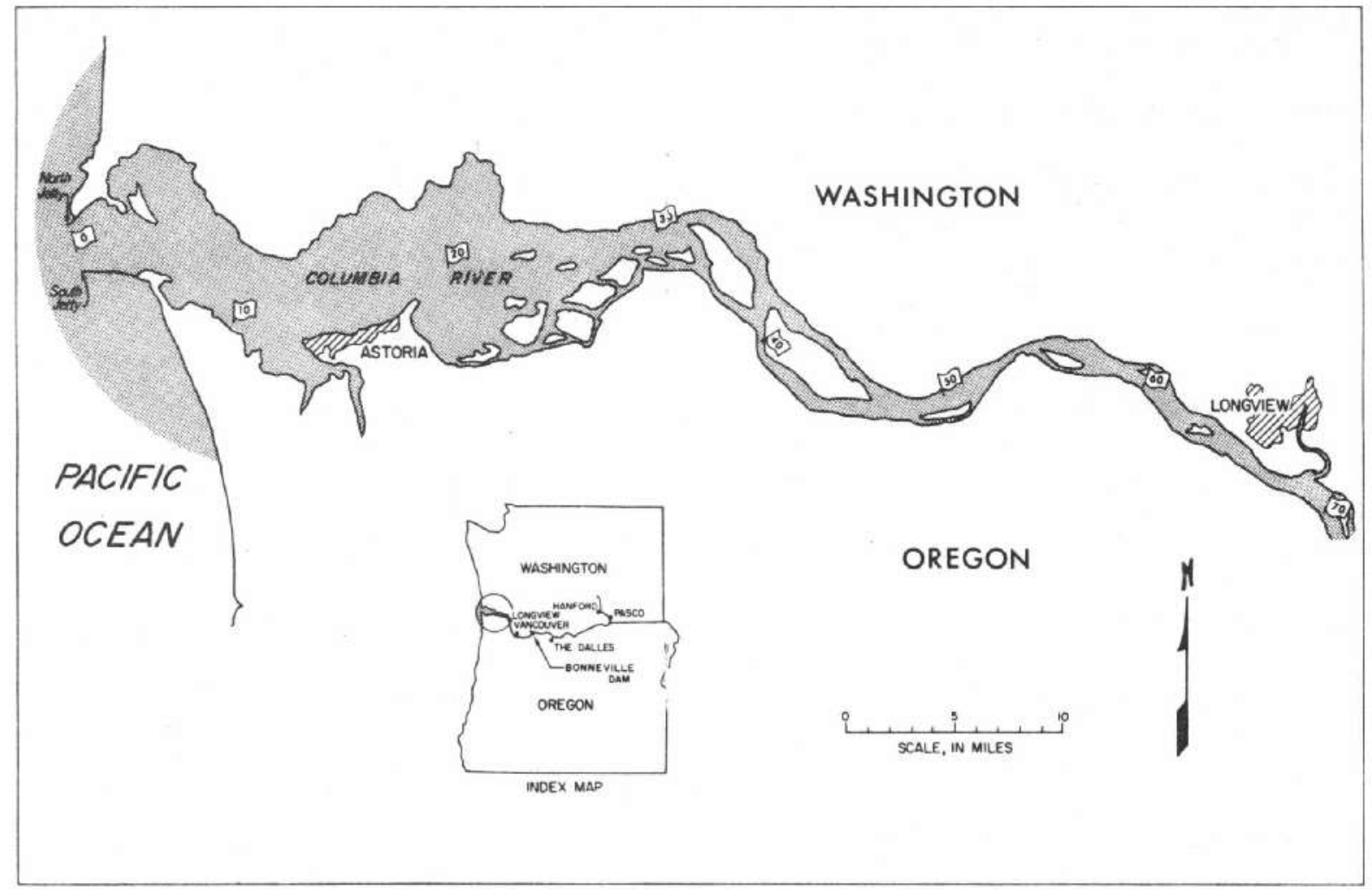

Figure 1.--Columbla River estuary. Flags show Columbia River mile. River mile 0 is on line with ends of north and south jetties. 
investigation of the uptake, transport, and release of radionuclides in the reach of the Columbia River between Pasco, Wash., and Longview, Wash. (fig. 1). The Richland Operations Office of the Atomic Energy Commission and one of its prime contractors, General Electric, cooperated in the investigation by arranging for and performing radiochemical analyses and by providing scientific expertise. The services originally provided by General Electric later were furnished by Battelle Memorial Institute when operation of the Hanford laboratories was transferred.

Iate in 1963, the Geological Survey, also in cooperation with the Atomic Energy Commission, began a separate, but related, investigation of radioactivity in the Columbia River estuary. The purpose of the investigation was to study the disposition and movement of radionuclides in estuarine environments. In particular, information was desired on (1) the spatial and temporal distribution of radionuclides; (2) the influences that complex circulation and sedimentation patterns created by salinity intrusion, tidal action, channel geometry, and variable freshwater flow have on the transport of radionuclides; and (3) the important processes involved during the movement of radionuclides from the fluvial environment to the ocean.

As a part of the estuary investigation, a survey was made in June 1965 of radionuclides in the streambed between the mouth and Longview. This report presents the results from the survey. At the outset it was apparent that the concentration of radionuclides was related to the composition of the sediment and that a knowledge of the distribution of one would aid in inferring the distribution of the other. For this reason, data on both radioactivity and sediment composition were obtained during the survey. In this report, data have been used to define 
the areal and stratigraphic distribution of radionuclides and sediment and to determine relationships among radioactivity, geomorphic expression, and physical characteristics of the sediment. This information provides the basis for a generalized qualitative description of the distribution of radionuclides in the estuary. The distributions and relations also have been utilized to inventory the amounts and species of radionuclides in the estuary bed at the time of the survey. The amounts, in turn, provide a basis for some generalizations about sediment transport.

Al1 radiochemical analyses presented in this report were performed by the Battelle-Northwest Radiological Chemistry and Technical Analysis Sections under the direction of Dr. Julian M. Nielsen. Dr. Jack L. Nelson, as well as others at Battelle-Northwest, performed the difficult task of devising sample-handling and analysis techniques for counting the extremely low-level, brackish-water samples. In addition, Drs. Nielsen and Nelson, and Mr. R. W. Perkins contributed valuable advice concerning the design of an in situ counting system. The investigation was carried on in 1963 and 1964 under the general supervision of L. B. Laird, district chemist, Geological Survey, and in 1965 under the general supervision of G. L. Bodhaine, district engineer, Geological Survey. The work was performed on behalf of the Division of Reactor Development and Technology, U.S. Atomic Energy Commission.

THE COLUMBIA RIVER ESTUARY

Description of the Estuary

The Columbia River estuary (fig. 1), for purposes of this investigation, is defined as beginning near Longview, Wash., which is about Columbia River mile (CRM) 65.8, and extending to a line between the outer 
ends of the north and south jetties (CRM 0) at the mouth. The upper end of the estuary approximately coincides with the farthest upstream point of flow reversal during periods of low upland river flow.

Based on long-term records (1878-1967) for the Columbia River at The Dalles, Oreg. (CRM 189; U.S. Geol. Survey, 1968), the average discharge of the Columbia River at Vancouver, Wash. (CRM 107; fig. 1), is about $200,000 \mathrm{cfs}$ (cubic feet per second). For the period 1963-67, the daily flow at Vancouver ranged from 78,900 to 675,000 cfs (U.S. Geol. Survey, 1968). Low flows occur from October through March and high flows from April through July. During this survey (June 14-28, 1965), the discharge at Vancouver averaged about 500,000 cfs (U.S. Geol. Survey, no date).

Tides in the Columbia River are of the mixed type characteristic of the Pacific Coast (two high waters and two low waters, all of different heights, during each lunar day). At the mouth, the mean tida1 range (U.S. Coast and Geodetic Survey, no date, p. 172-173) is 5.6 feet and the mean diurnal range is 7.5 feet. At Longview, the mean tidal range and the diurnal range are 3.3 and 4.0 feet, respectively. Tides affect Columbia River stages as far upstream as Bonnevi1le Dam (CRM 140) during periods of low upland river flow.

Cold saline water from the ocean intrudes into the lower part of the estuary. The nature of the saline-fresh water circulation in the estuary is such that Neal (1965, p. 25-26), using the system of Pritchard (1952), classified the estuary as a Type B (partially mixed) estuary with a tendency to be well mixed during some flow and tidal conditions. A partially mixed estuary is one in which exchange between the relatively saline water near the bottom and the relatively fresh water near the top 
produces a vertical-salinity gradient that varies more or less gradually with depth and a longitudinal salinity gradient that increases in the seaward direction. During low upland river flow the presence of saline water near the estuary bottom can be detected as far upstream as Harrington Point (Wash.; CRM 23); however, as the upland river flow increases, the length of the saline-water intrusion is proportionately reduced (Lockett, 1967). During the time of the survey reported herein, bottom water with significant salinity probably intruded no farther up the estuary than about Astoria, Orag. (CRM 14).

The spatial and temporal distribution of saline water, circulation and sedimentation patterns, and the influence of waves and tides tend to divide the estuary into areas where physical, chemical, and biological processes are significantly different. Seaward from about CRM 7-8 the environment is basically marinie in character and Iandward from about CRM 23 the environment is fluvial; the environment in the intervening area is transitional in nature.

The Columbia River estuary may be divided into two geomorphically distinct parts. In the upper part (p1.1), between Longview and Aldrich Point (Oreg.; CRM 31), the estuary lies between steep valley walls that are about 1.7 to 3.4 miles apart. The Columbia River occupies a main channel that ranges from about 0.4 to 1 mile in width at mean lower low water during low upland river flows. In addition, small channels, the largest of which are Cathlamet and clifton Channels, and smaller sloughs, such as Wallace, Bradbury, and Fisher Island Sloughs, range from about 0.1 to 0.6 mile in width and carry river flow around six large permanent islands. Puget Island, the largest, is about 1.7 miles wide and 5.1 miles long and is used extensively for agricultural purposes. The 
remaining permanent islands are used chiefly for grazing during lowwater periods as are extensive flood plains adjacent to the river.

Below Aldrich Point (p1. 2), the estuary broadens to a maximum width of about 9.4 miles in the vicinity of Harrington Point. The minimum width in the lower part of the estuary is about 3.8 miles near Astoria. The valley walls are less steep than in the upper part, and four major embayments (p1. 2), Youngs Bay, Baker Bay, Cath1amet Bay, and Grays Bay, extend from the estuary proper into stream valleys draining the adjacent highlands. Flow in the lower part spreads over the entire estuary at high tide but is mainly confined to a channel along the north side and to the south or main navigation channel (shown by dashed lines in $\left.\mathbf{p}^{1}, 2\right)$. Extensive areas of the estuary near the upper end of the lower part and where the estuary is widest, are occupied by semipermanent, diurnally inundated, vegetated islands. Equally large areas of nonvegetated islands appear throughout the lower part of the estuary during periods of low tides.

\section{Radionuclides in the Columbia River}

At Vancouver (CRM 107), approximately 96.5 percent of the total radionuclide discharge is ${ }^{5 I_{C r}}$ (chromium-51); 2.3 percent is ${ }^{65} \mathrm{Zn}$ (zinc-65); and the remaining 1.2 percent includes a variety of other radionuclides (Foster, 1964, p. 13). Measurable amounts of ${ }^{32} \mathrm{P}$ (phosphorus-32); ${ }^{46} \mathrm{Sc}$ (scandium-46); ${ }^{54} \mathrm{Mn}$ (manganese-54); ${ }^{58} \mathrm{Co}$ (cobalt-58);

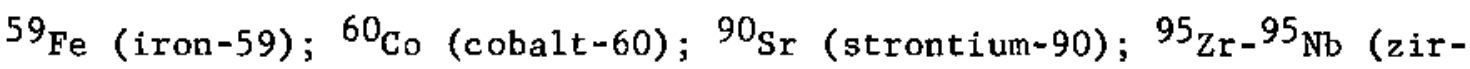
conium-95-niobium-95); ${ }^{106} \mathrm{Ru}$ (ruthenium-106); ${ }^{124} \mathrm{Sb}$ (antimony-124); ${ }^{131} \mathrm{I}$ (iodine-131); ${ }^{137} \mathrm{Cs}$ (cesium-137); $140_{\mathrm{Ba}}$ (barium-140); ${ }^{141_{\mathrm{Ce}}}$ (cerium-141); and ${ }^{239} \mathrm{~Np}$ (neptunium-239) have been reported at Vancouver (Foster, 1964; Haushild and others, 1966; and W. L. Haushild, written 
commun., 1968). Radionuclide discharges depend on the operations at Hanford and on river discharge. Foster (1964) reported that in calendar years 1961, 1962, and 1963, the annual mean daily discharges of ${ }^{51} \mathrm{Cr}$ and ${ }^{65} \mathrm{Zn}$ at Vancouver were 840,$44 ; 650,29$; and 860,28 curies, respectively, and Haushild (written commun., 1968) computed comparable rates for 1964 as 1,100 and 18 curies per day. Nelson, Perkins, Nielsen, and Haushild (1966) studied short-term variations and found that at Vancouver in 1964 daily discharges of ${ }^{65} \mathrm{Zn}$ and several other radionuclides were more than 10 times greater in June than they were in September. They attributed the high discharges in June to the resuspension and transport of sediment by the spring freshet. During June, the ${ }^{65} \mathrm{Zn}$ transported by particulate matter (matter $\geq 0.45$ micron) was about 97 percent of the total ${ }^{65} \mathrm{Zn}$ discharge; at other times of the year the percentage was less and was as $10 \mathrm{w}$ as 48 percent in December. Other radionuclides that tend to associate with particulate matter $\left({ }^{46} \mathrm{Sc}\right.$, ${ }^{54} \mathrm{Mn},{ }^{59} \mathrm{Fe},{ }^{58} \mathrm{Co}$, and ${ }^{60} \mathrm{Co}$ ) exhibited similar behavior and at times the discharges of these nuclides were greater at Vancouver than they were at Pasco, which is about 223 miles upstream. In contrast, the daily discharge of ${ }^{5 l} \mathrm{Cr}$, which is transported mainly (92 percent) in solution, did not vary greatly during the year.

Other factors that affect the magnitude of daily radionuclide discharges include stable element concentrations and uptake and release reactions. Silker (1964) observed that the concentrations of $\mathrm{Zn}$, Co, $\mathrm{Mn}, \mathrm{Fe}$, and Sc in solution in the Columbia River upstream from the reactors vary throughout the year and are higher in the spring than in the winter. It seems likely that as the concentrations of stable elements increase, the concentrations of activated radioisotopes of some of these 
elements also increase. The sorption and desorption of radionuclides by sediment and biota also influence radionuclide discharges; however, the magnitude of such reactions is not well documented.

Seymour and Lewis (1964) estimated the amount of radionuclides in the entire reservoir below Vancouver (river, estuary, and ocean) during calendar years 1961, 1962, and 1963 from mean daily radionuclide discharges at Vancouver. For the estimates, they assumed that the reservoir was essentially in equilibrium and computed the amount of radionuclides that would decay at a rate just sufficient to offset (equal) the continuous inflow of radionuclides. The average of the three yearly estimates was 40,000 curies of which 29,000 curies was ${ }^{51} \mathrm{Cr}$ and 11,000 curies was ${ }^{65} \mathrm{Zn}$.

Data on radionuclides in Columbia River bed sediments generally are more limited than data on radionuclides in water and suspended sediments. Nielsen (1963, p. 91-112) and Nelson (1965, p. 3.80-3.88; 1967, p. 88-93) reported on the concentration and distribution of radionuclides in Columbia River and reservoir sediments in the vicinity of Hanford. W. L. Haushild (written commun, 1968) surveyed radionuclides in Columbia River bed sedlments between Pasco and the head of the estuary at Longview and computed an amount of about 38,000 curies in that reach.

Some data on the general radiation levels and kinds of radionuclides in Columbia River estuary bed sediments have been obtained in conjunction with studies on the distribution of the Columbia River plume in the Pacific Ocean (Barnes and Gross, 1966). Jennings (1966) used an immersible scintillation detector for in situ measurements of radioactivity at about 35 locations in the estuary and in Youngs River. He readily detected ${ }^{51} \mathrm{Cr},{ }^{65} \mathrm{Zn},{ }^{54} \mathrm{Mn}$, and naturally occurring ${ }^{40} \mathrm{~K}$ (potassium-40) at 
most measurement sites. Highest levels were observed along the eastern side of Tongue Point (Oreg.; CRM 18). His data also indicated that the ratio of ${ }^{51} \mathrm{Cr}$ to ${ }^{65} \mathrm{Zn}$ decreased substantially in December 1964 shortly after a Columbia River flood: the change was attributed to scour of the streambed.

Johnson, Cutsha11, and Osterberg (1967) studied the retention of ${ }^{65} \mathrm{Zn}$ by Columbia River estuary sediment. In laboratory experiments, they found that when sediment from the lower estuary was leached with sea water, only about 3 percent of the ${ }^{65} \mathrm{Zn}$ was displaced. When the sediment was leached with dilute $\mathrm{CuSO}_{4}$ (copper sulfate), however, approximately 40 percent of the ${ }^{65} \mathrm{Zn}$ was displaced. They concluded that most of the ${ }^{65} \mathrm{Zn}$ was held by a mechanism termed "specific sorption" wherein a sorbed metal cannot be displaced by alkali or alkaline earth ions but can be displaced by other transition metals.

\section{EQUIPMENT, DATA COLLECTION, AND ANALYTICAL TECHNIQUES}

During the early phase of this investigation, special equipment was developed to measure radioactivity and collect samples of the bed material. In order to monitor directly levels of radioactivity in the streambed, a single-channel radiation-detection system was adapted for in situ measurements (Prych, Hubbell, and Glenn, 1967). The scintillation detector (fig. 2), which consists of a 5-inch by 2-inch plastic phosphor coupled to a 3-inch photomultiplier tube, is encased in a waterproof aluminum housing having a 3/8-inch-thick bottom. A plastic phosphor was selected because of its sensitivity and resistance to damage from mechanical and thermal shocks, rather than its resolution, which is relatively low. Both a preamplifier and an annular-battery pack of forty-two 30-volt batteries are housed with the detector. Radiation emanating from the 
sides and above the detector is attenuated by a conical lead shield inside the housing and an annular lead ring at the base of the housing. The detector housing mounts into and forms the bottom of a towing sled (fig. 3). A 3/16-inch OD, single-conductor, armored cable serves as both the signal and the tow line.

In early experimental work, several towing tracks were made with the sled-detector unit. Although the equipment operated satisfactorily, the sled appeared to skip along the bed whenever the towing speed exceeded about 4 fps (feet per second) with the result that the counting geometry varied sufficiently to affect the count rates. In addition, obstructions on the bottom snagged the sled on numerous occasions. Because of these difficulties, towing was discontinued and in situ measurements were made by lowering the detector-sled unit to the bed while the boat hovered or was anchored in essentially a fixed position.

The radiation-detection system was used to measure only gross-gamma radiation and no effort was made to identify, in situ, individual radionuclides in the bed. In order to maintain a standard reference-energy level, the instrumentation was adjusted, on the basis of energy-voltage calibrations with a ${ }^{137} \mathrm{Cs}$ source, to exclude all absorbed radiation having an energy less than $100 \mathrm{Kev}$ (thousand electron volts). During normal operation the battery-pack voltage decreased gradual1y, with the result that the reference-energy level shifted between calibrations. Count rates were adjusted by applying a proportionality factor determined from the magnitude of the energy shift and the rate of change of count with energy as determined from integral spectrutas of the activity in the bed at many locations throughout the estuary. On the average, adjustments increased count rates about 13 percent. 


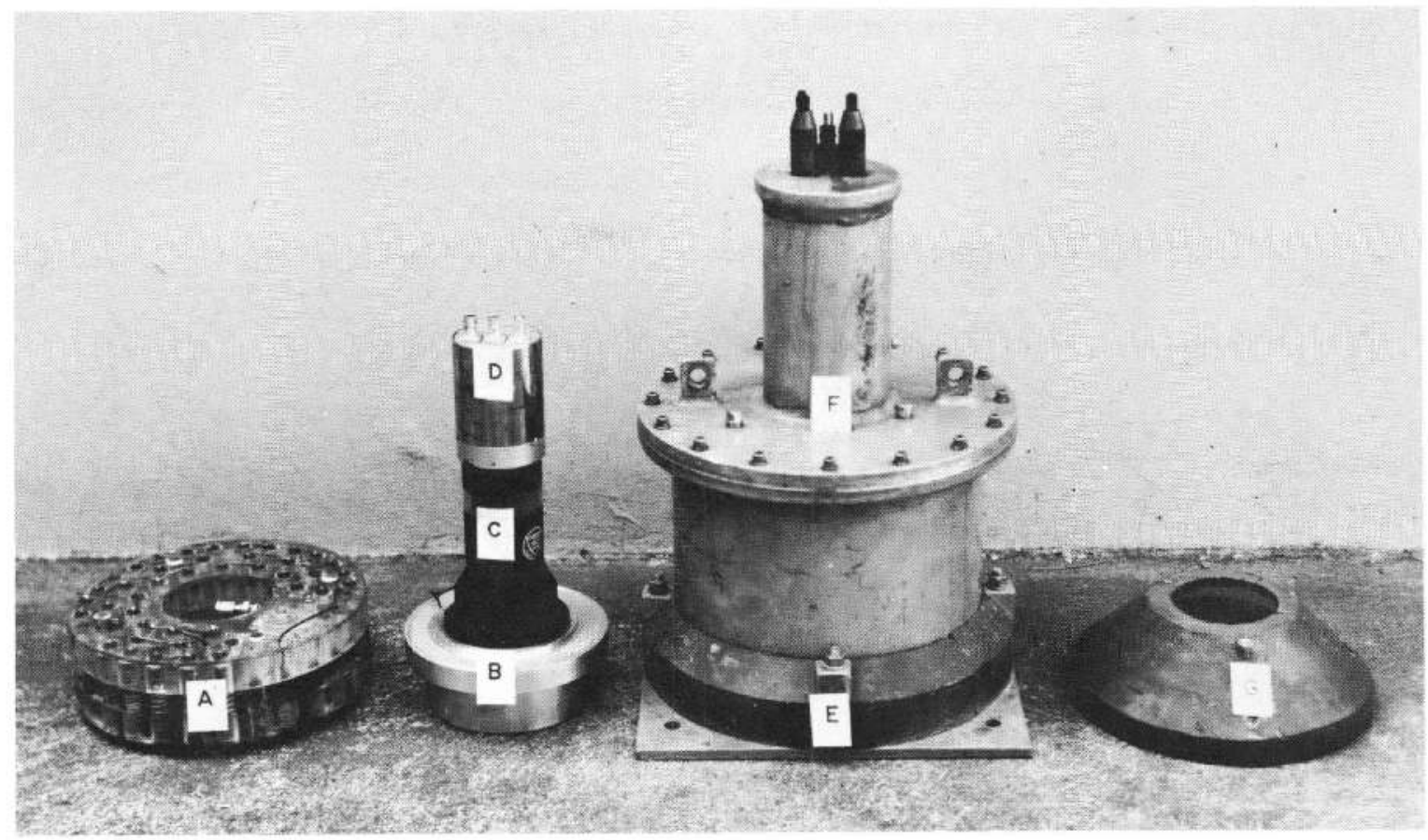

Figure 2.--Scíntillation detector housing and components: (a) battery pack, (b) phosphor, (c) photomultiplier tubes, (d) preamplifier, (e) annular shield, (f) housing, (g) conical shield. (From Prych, Hubbell, and Glenn, 1967.)

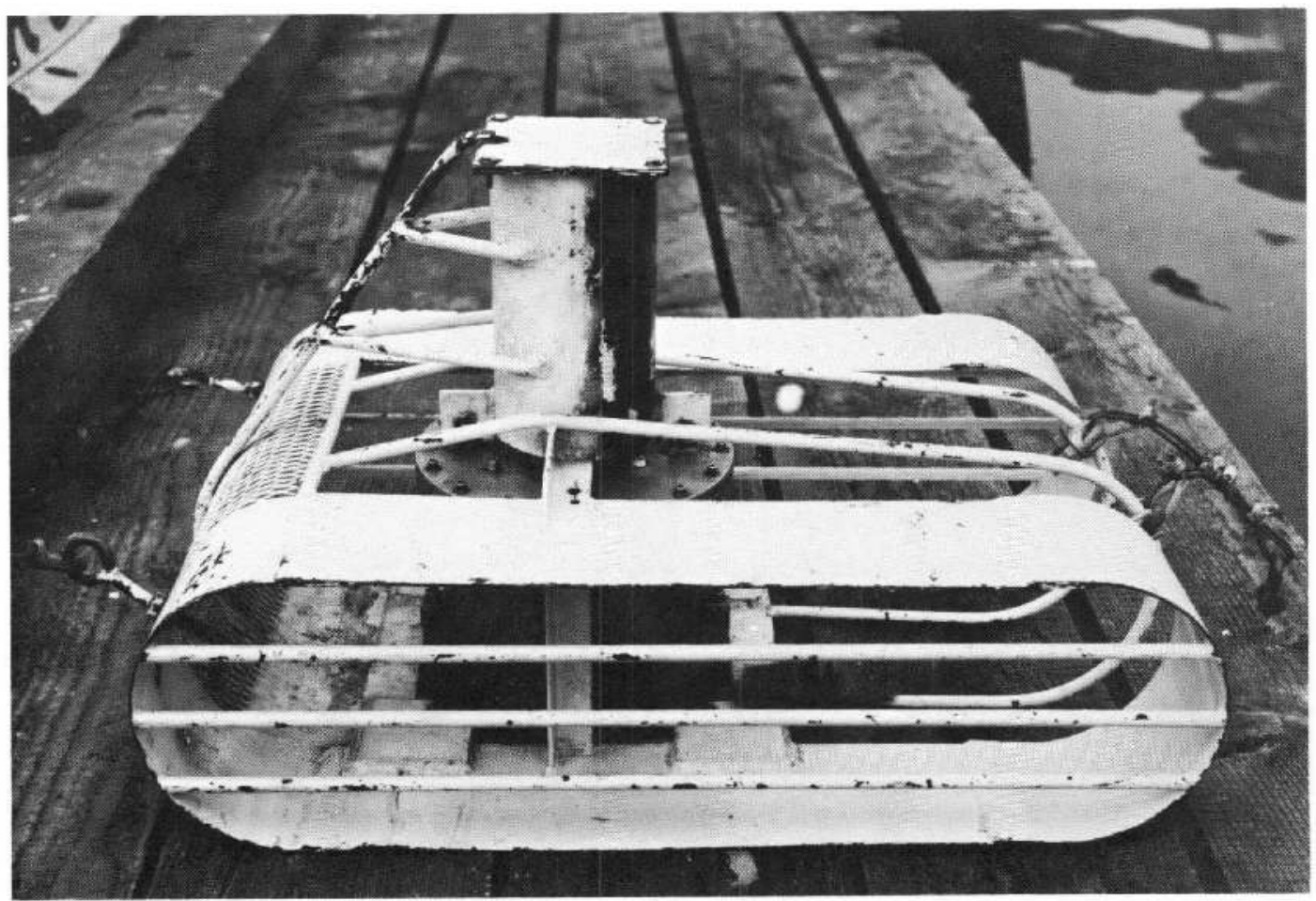

Figure 3.--Radiation detector and sled. (From Prych, Hubbel1, and Glenn, 1967.) 
Samples of the sediment at the surface of the streambed were obtained with a standard US BM-54 bed-material sampler (U.S. Inter-Agency Water Resources Council, 1966). This sampler (fig. 4) collects a 300-400 gram semicylindrical slice from the bed and retains both fine sediment and interstitial water collected with the sample.

Cores were obtained throughout the estuary with a portable vibro corer (Prych and Hubbel1, 1966) that was designed specifically for use in the Columbia River and in the estuary, where the bed material is coarse grained and flow velocities may exceed 5 fps. The corer (fig. 5) penetrates about 6 feet into the bed as a result of the combined effects of an electro-mechanical vibrator mounted at the top of the core barrel, a piston that slides inside the core barrel liner but remains stationary with respect to the bed, and a suspension system that converts an upward force on the main suspension cable to a downward axial force on the barrel. The cores, which were collected and retained in a plastic liner, were relatively undisturbed although some smearing occurred at the sediment-liner interface, some slight interior warping may have occurred, and small quantities of water may have percolated upward in cores of coarse sand.

Data for this survey were collected in $14 \operatorname{cross}$ sections ${ }^{1 /}$ (pls. 1-2) spaced approximately 5 miles apart, between Longview and the estuary mouth, and at other selected locations; data for 10 surficial-sediment samples collected in the Astoria area in 1964 and two cores (C3 and C6) collected in January 1965 also are included in this report for comparative purposes. At each cross section, in situ measurements were made of

1/ In this report the term "cross section" designates a location where samples were collected along an irregular line that crosses the estuary approximately normal to the flow. 


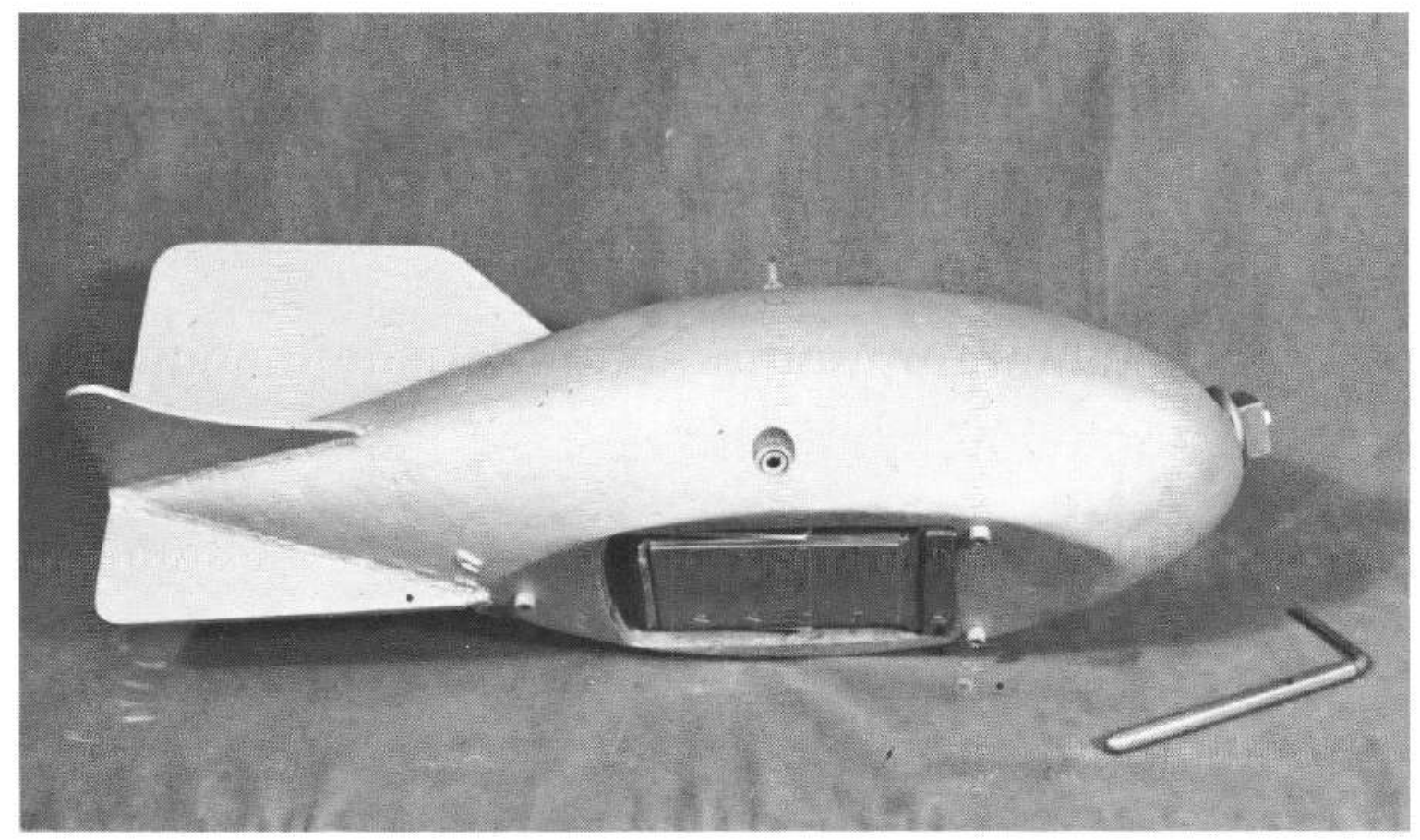

Bucket retracted

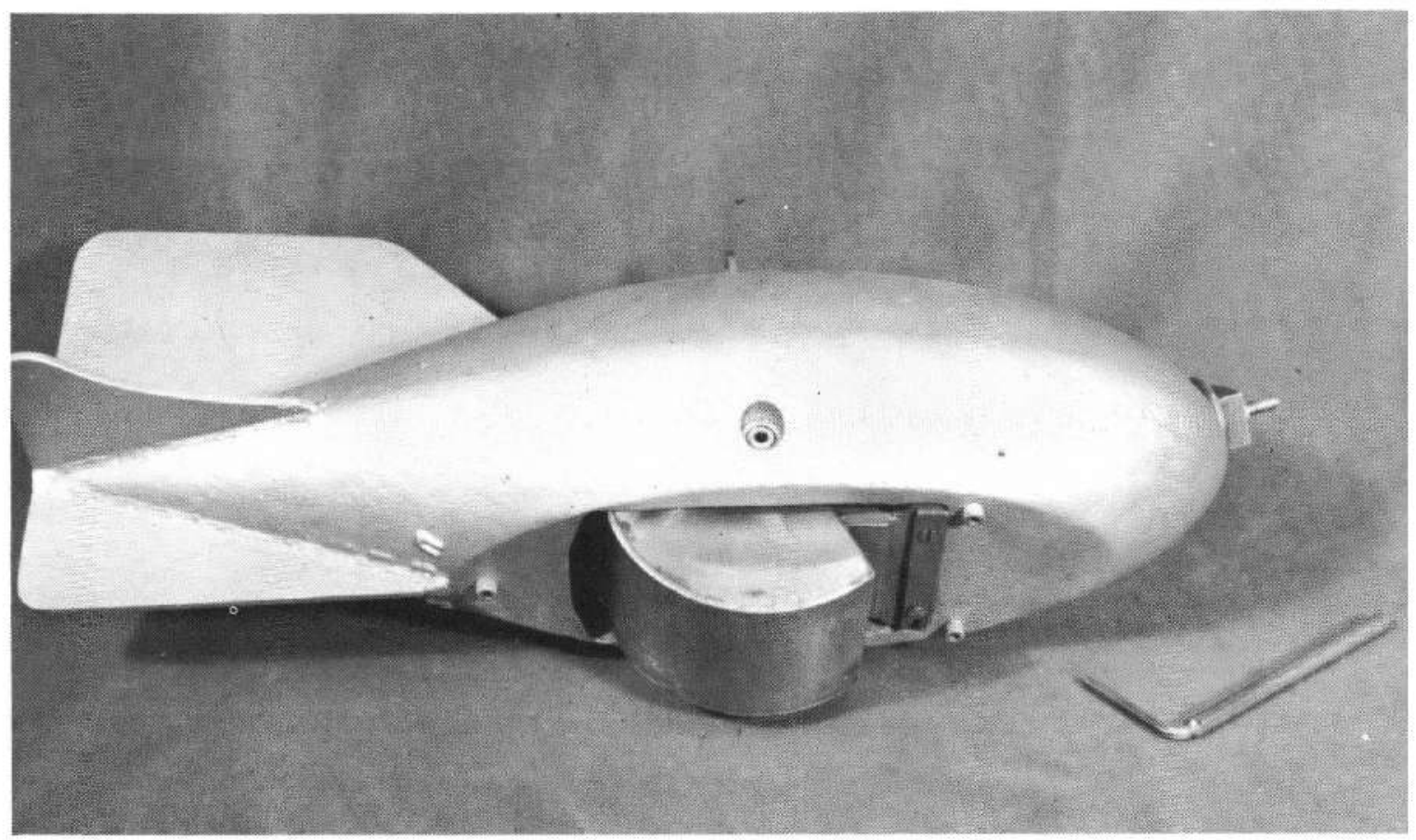

Bucket exposed

Figure 4.--Bed-material sampler, US BM-54.

(From U.S. Inter-Agency Water Resources Council, 1966.) 


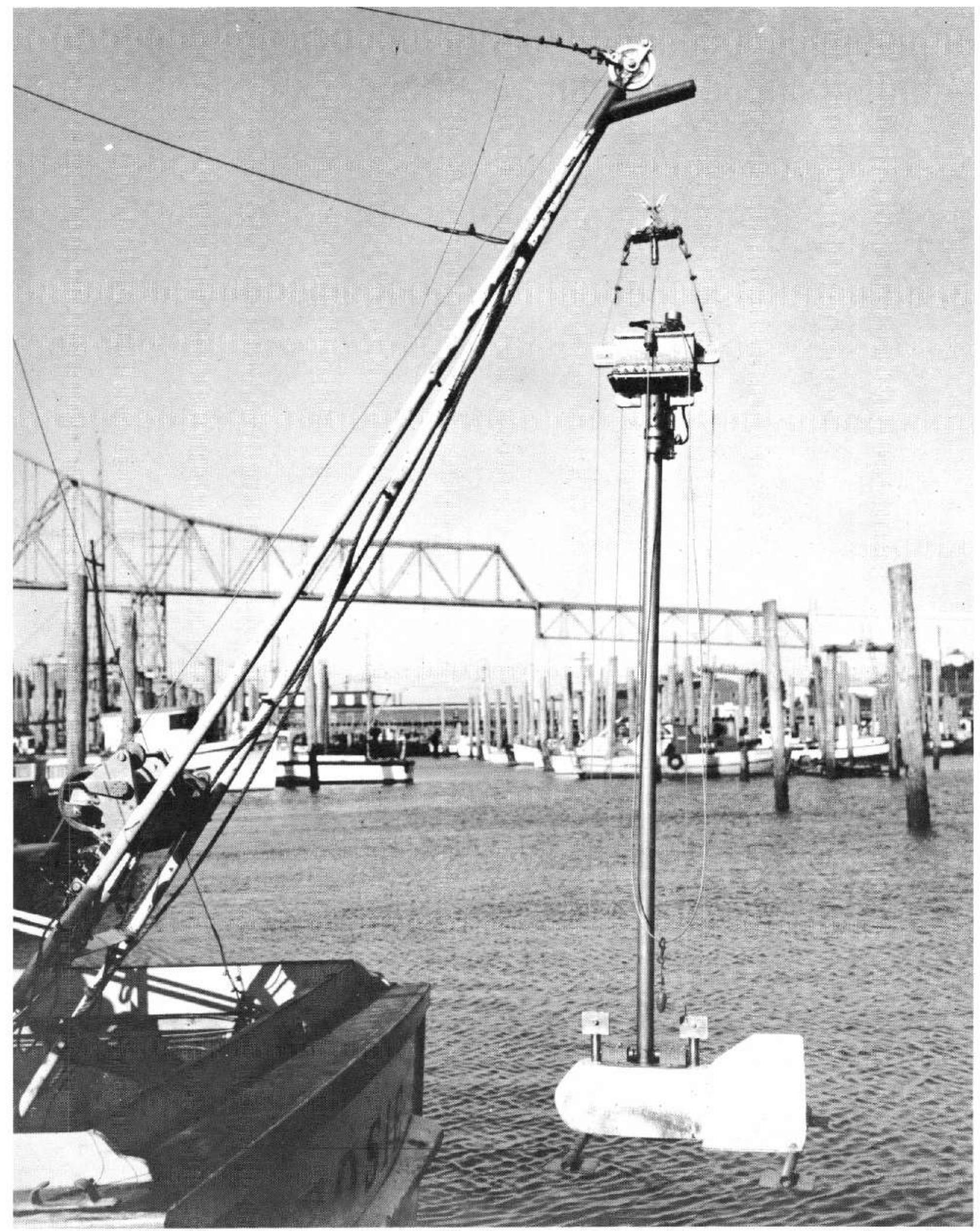

Figure 5.--Core sampler prepared for coring.

(From Prych and Hubbel1, 1966, p1. 1.) 
radioactivity in the streambed and samples of the surficial bed sediment were collected. At most points, the in situ measurement and the surficial sample were collected simultaneously while the boat hovered in a nearly fixed position. Due to the positioning of equipment on the boat and some boat movement, the in situ measurement and the sample were obtained at slightly different spots on the bed. In or near most cross sections one or more cores were obtained. The data-collection points were spaced in an attempt to define variations in levels of radioactivity and in textures of the bottom sediments. In a11, 177 surficial sediment samples and 27 cores were collected, and 187 measurements of in situ radioactivity were made.

Portions of 71 surficial sediment samples and 287 selected 1 - or 2-inch-thick segments from the cores were analyzed in the Battelle-Northwest Laboratory by multidimensiona1, gamma-spectrometry counting techniques (Perkins, 1965) to provide information on the concentrations of specific radionuclides. In addition, particle-size distributions of 172 surficial sediment samples and 147 segments of cores were determined. Many, but not all, surficial samples and core segments were analyzed to determine both radionuclide content and size distribution.

In subsequent tables and graphs, individual surficial sediment samples are designated by a number preceded by a "G." The first three digits of the number indicate the sampling location (pls, 1-2), and the last two digits indicate the year in which the sample was collected (such as G344---65). Replicate samples or analyses are indicated by a number between the location number and the year number (G344-1-65). Special samples, which normally were a separate from the bulk sample, are designated with a letter between the location number and the year number (G254-A-65). 
Cores are designated by a location number (pls. 1-2) preceded by a " $\mathrm{C}$ "; replicate cores have a Roman numeral following the location number. Individual segments of each core are designated by the core location number followed by two or three additional digits; the last digit is the length of the segment, in inches, and the preceding digit(s) is the distance, in inches, from the bed surface to the top of the segment. For example, c367-23-2 represents a segment of the core collected at location 367 ; the segment extends from 23 to 25 inches below the bed surface.

Surficial sediment samples were split and one part retained in a wet condition for size analysis; the second part was sent to BattelleNorthwest for radionuclide analysis. Core samples, however, were so small that the same material had to be used for both radionuclide and size analyses. Because the sediment was dried for the radionuclide analyses, it was retained in that condition during preparation for size analyses. The distribution of particles coarser than $0.062 \mathrm{~mm}$ and finer than $2 \mathrm{~mm}$ was defined by the visual-accumulation tube method (U.S. InterAgency River Basin Comm., 1957), and the distribution of particles finer than $0.062 \mathrm{~mm}$ was determined by the pipette method (U.S. Inter-Agency River Basin Comm., 1941). Standard sieving techniques were used to define the distribution of particles coarser than $2 \mathrm{~mm}$. Samples collected in the part of the estuary that is continuously or periodically exposed to salt water were rinsed with distilled water prior to analysis to remove excess salt and reduce the possibility of flocculation. Rinsing was repeated as necessary until the supernatant liquid contained a chloride content of less than that of Columbia River water. Before pipette analysis, each sample was treated with a deflocculating agent (sodium hexametaphosphate) and agitated in a laboratory mixer for 10 minutes. 
Results of the size analyses are presented in appendixes I and II in terms of the size-distribution statistics of Inman (1952), which are based on the phi system $2 /$, and by the statistics of Trask (1932). The various statistics in the appendixes were determined by a computer program according to a technique that defines critical values (millimeter or phi values at $5,10,16,25$ percent finer, and so forth) from the size distribution in a manner exactly equivalent to 11near interpolation between defined points on a graph of probability (percent-finer scale) versus logarithm of size (phi scale). In some analyses the distribution at one or both extremes was not defined adequately. For these distributions, critical values were obtained by linear extrapolation from the two closest defined points on the distribution. Whenever the extrapolations indicated that 5 percent or more of a sample was finer than $6.2 \times 10^{-5}$ am, the 5-percent-finer value was arbitrarily set at a phi value of 14.00 . All analyses characterized by values determined by extrapolation may be somewhat in error; these analyses accordingly are footnoted in the appendixes.

The statistics computed with the formulas of Inman (1952) are derived from analogies to central-moment measures. In accordance with Inman (1952) and McManus (1963), the following nomenclature is used in appendixes I and II and throughout the text: MEAN, mean size, mean grain size, or mean grain diameter characterizes central tendency; SORT, or deviation measure characterizes dispersion; ALPHA 1 or skewness measure characterizes skewness based on the central 68 percent of the distribution; ALPHA 2 characterizes skewness based on the central 90 percent of the distribution; and BETA characterizes kurtosis. Values of SORT (or $\underline{2} / \Phi=-\log _{2} \mathrm{D}\left(\right.$ Krumbe1n, 1934) or $\Phi=-\log _{2} \frac{\mathrm{D}}{1.0 \mathrm{~mm}}$ (McManus, 1963), where $\mathrm{D}$ is the particle diameter in millimeters. 
deviation measure) represent the number of size classes on the Wentworth (1922) scale spanned by the central 68 percent of the distribution and ALPHA 1 (or skewness measure) represents the relative number of size classes on the Wentworth scale between the median and a mean computed for the central 68 percent of the distribution. A positive value of ALPHA 1 indicates the distribution is skewed toward the fine sizes (the "tail" of the distribution extends toward the fine sizes) and a negative value indicates the distribution is skewed toward the coarse sizes.

The statistics of Trask (1932) are computed from actual size values expressed in millimeters rather than millimeter values converted to phi values. Trask's SORT and SKEW (app. I and II) represent measures of dispersion and skewness, respectively, determined from the ratios of sizes at quartiles on the distribution curve.

TEXTURAL CHARACTERISTICS OF BOTTOM SEDIMENTS

\section{Surficial Sediment}

Textural data for 172 surficial sediment samples from the estuary are shown in appendix I and are summarized in figure 6 . These data indicate that sand $(-1.0<$ phi $\leq 4.0)$ is the dominant sediment size in the estuary. Whereas many samples contain small but significant quantities of silt $(4.0<p h i<8.0)$, clay-size material (phi $\geq 8.0)$ generally is represented only sparsely. Although not shown in the triangle diagram of figure 6 , about 24 percent of all samples from the estuary contained some gravelsize material (phi<-1.0); the proportion of gravel in these samples ranged from 1 to 51 percent and averaged about 6 percent. The available data indicate that an "average" sediment sample from the estuary would consist of about 1 percent grave1, 84 percent sand, 13 percent silt, and 2 percent clay. 


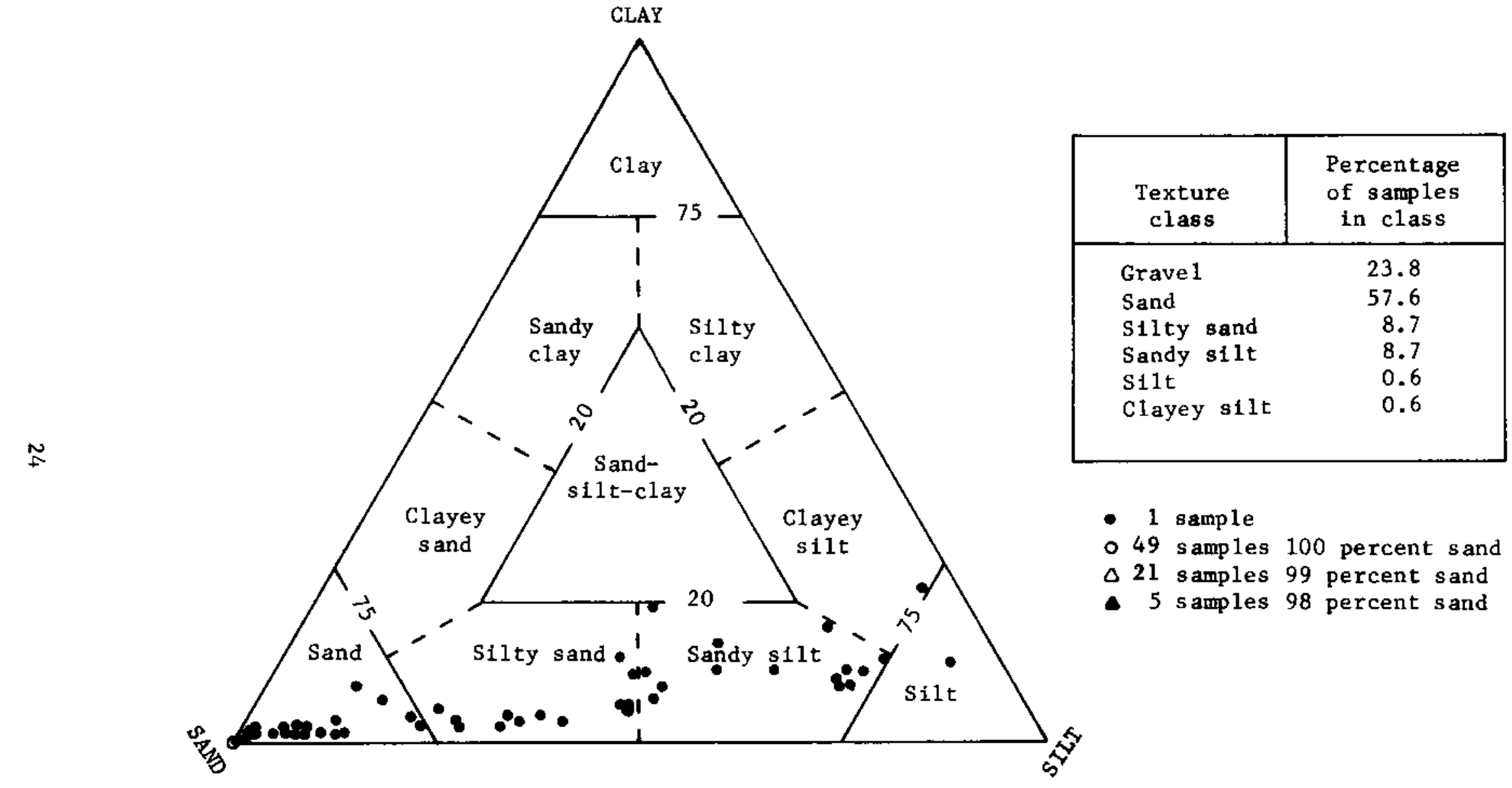

Figure 6.--Sand:silt:clay relations for surficlal sediment samples from the Columbla River estuary. Texture classes are those of Shepard (1954). All samples with any gravel-size material axe excluded from the triangle diagram and are considered to be in the gravel-texture class. 
The textural characteristics of the samples vary widely both within any given cross section and among cross sections. As a result, individual samples cannot be compared directly to discern spatia1 trends in texture. These trends can be identified only by grouping the samples into various classes that can be treated statistically. The number of meaningful classes and the criteria for assigning samples to a class, of course, depend on the objectives of the comparison, on a rational basis for recognizing and delineating the classes, and on the number of samples and amount of classification data that are available. As an example, it is of interest to determine whether sediment texture changes along the estuary in response to the changing hydrologic regime. This might be done by comparing among cross sections averages of selected textural statistics of all samples from a cross section. However, because the texture is variable and the sampling density is low, cross-section averages are not highly meaningful in terms of the stated objective. The assignment of samples into classes within each cross section and the grouping of cross sections seems to be a reasonable alternative.

Selected particle-size distribution statistics for each sample are plotted in figures 7 to 13 with each sample shown in its correct position in the cross section relative to adjacent samples. Inspection of these data indicates that part of the within-cross-section textural variance can be eliminated if cross-section samples are divided into three classes. These classes are called "channels," "slopes," and "flats." With data from subsequent studies, it is anticipated that additional classes (or divisions of the above classes) will be recognized.

As indicated by class names, geomorphic criteria are used to identify and delineate classes. Channels are areas where flow usually is conveyed 


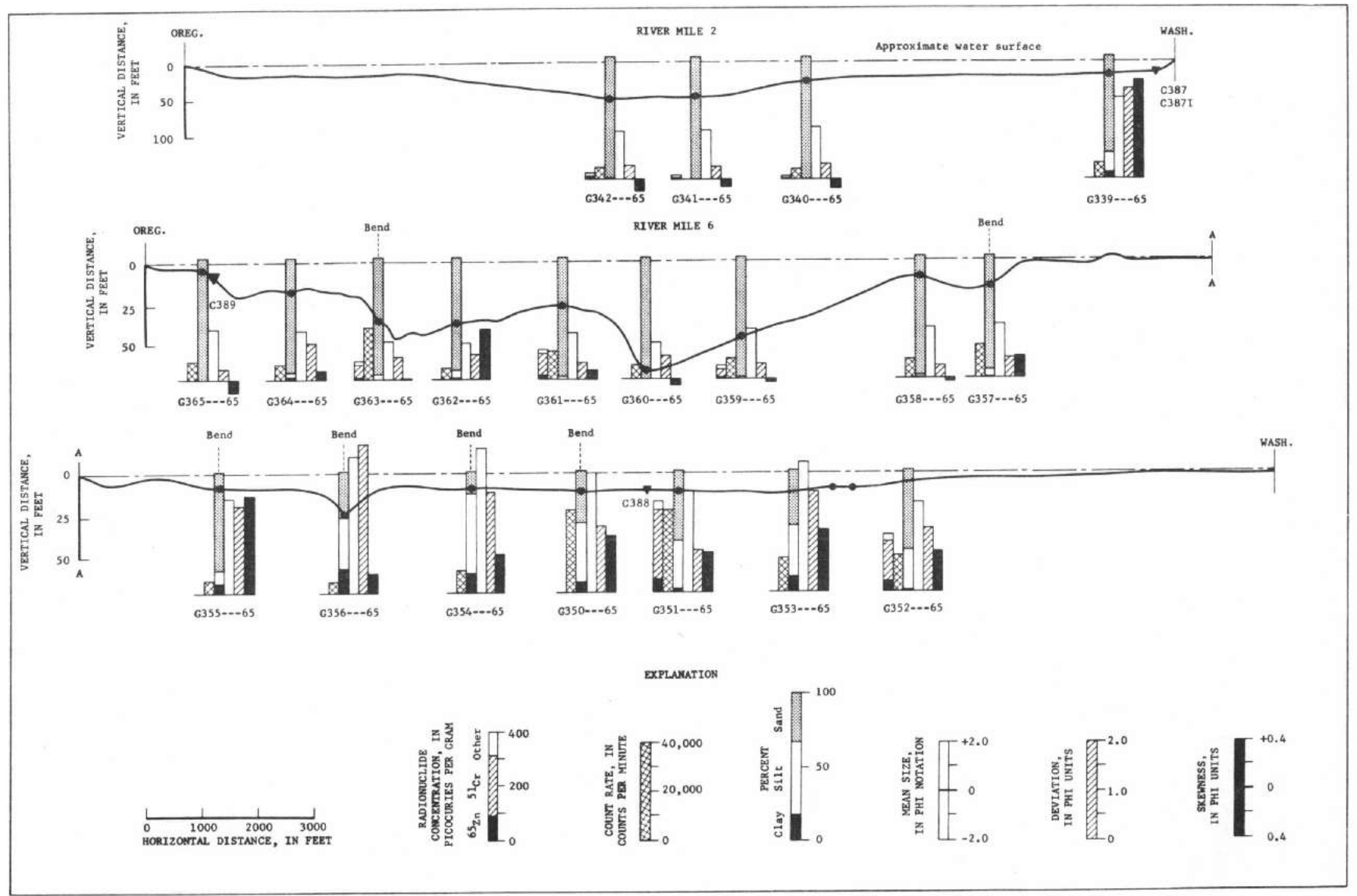

Figure 7.--Radioactivity and texture at surficial sediment sample locations in cross sections at river miles 2 and 6 . Dots and triangles on the bed proffle locate positions of surficial sediment and core samples, respectively. Baseline for bar graphs is zero. Alignment of cross sections corresponds with that shown on plate 2 , and significant bends are indicated accordingly. 


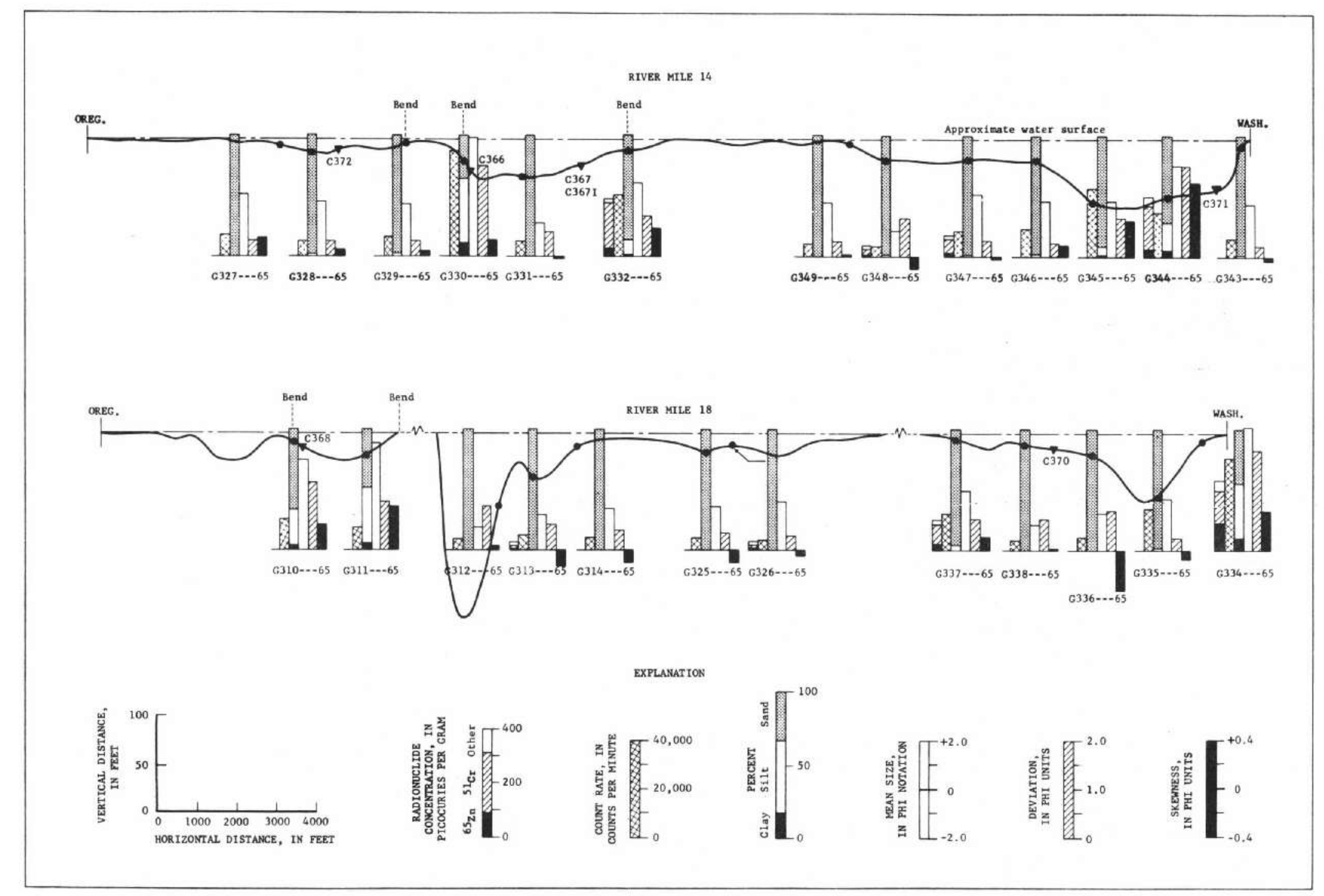

Figure 8.--Radioactivity and texture at surficial sediment sample locations in cross sections at river miles 14 and 18. Dots and triangles on the bed profile locate positions of surficial sediment and core samples, respectively. Baseline for bar graphs is zero. Alignment of cross sections corresponds with that shown on plate 2, and significant bends are indicated accordingly. 

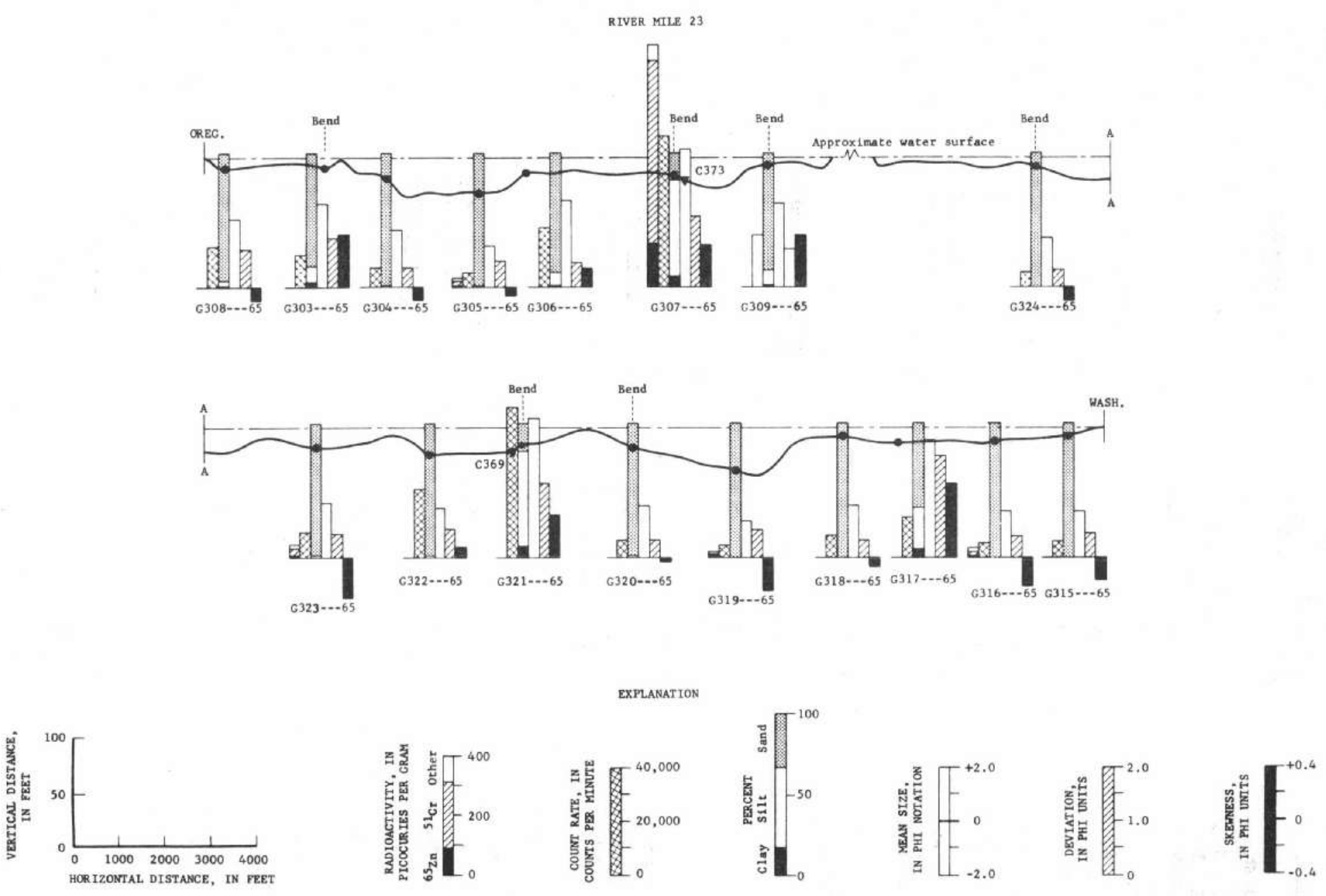

Figure 9.--Radioactivity and texture at surficial sediment sample locations in cross section at river mile 23. Dots and triangles on the bed profile locate positions of surficial sediment and core samples, respectively. Baseline for bar graphs is zero. Alignment of cross section corresponds with that shown on plate 2, and significant bends are indicated accordingly. 
RIVER MLLE 27
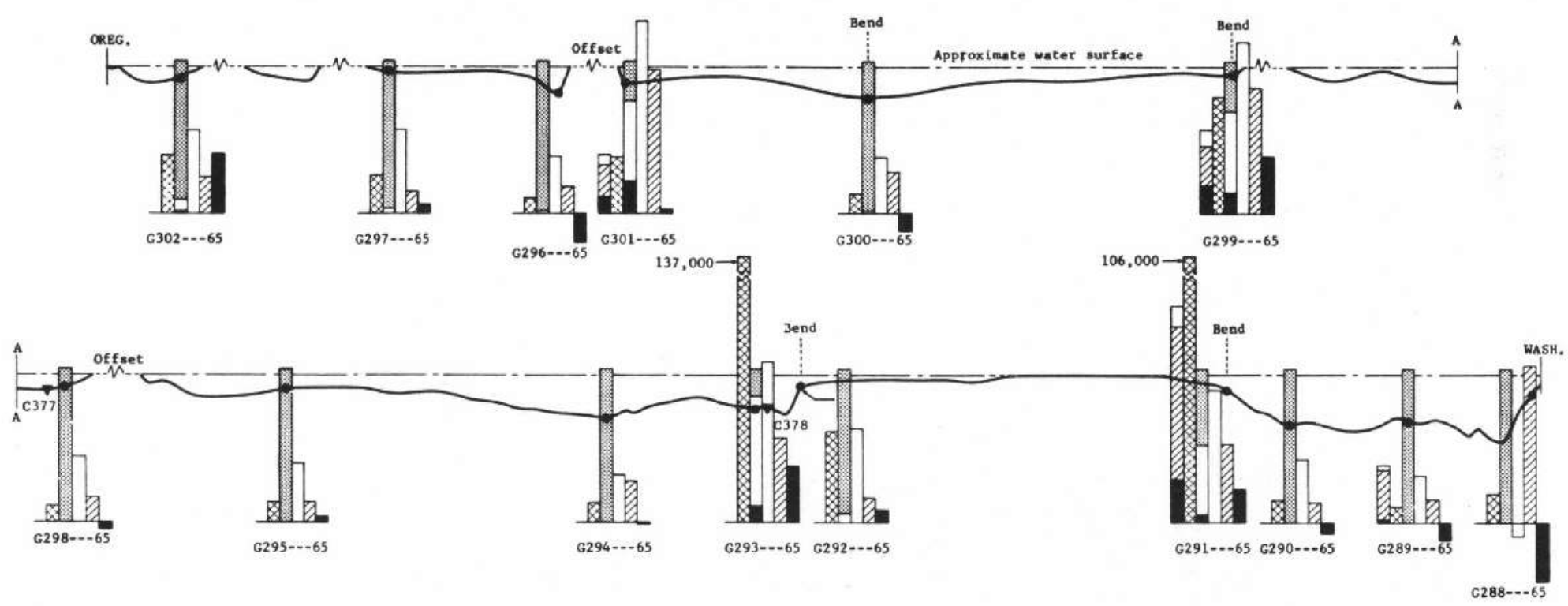

Expunution
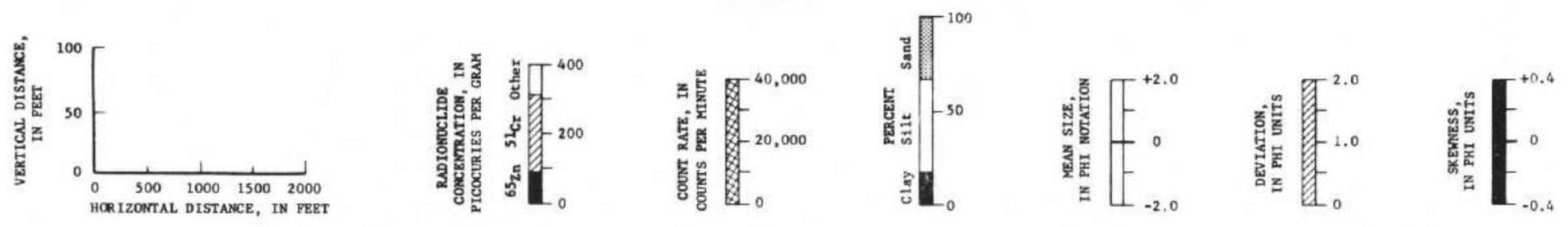

Figure 10.--Radioactivity and texture at surficial sediment sample locations in cross section at river mile 27. Dots and triangles on the bed profile locate positions of surficial sediment and core samples, respectively. Baseline for bar graphs is zero. Alignment of cross section corresponds with that shown on plate 2 , and significant bends and offsets are indicated accordingly. 

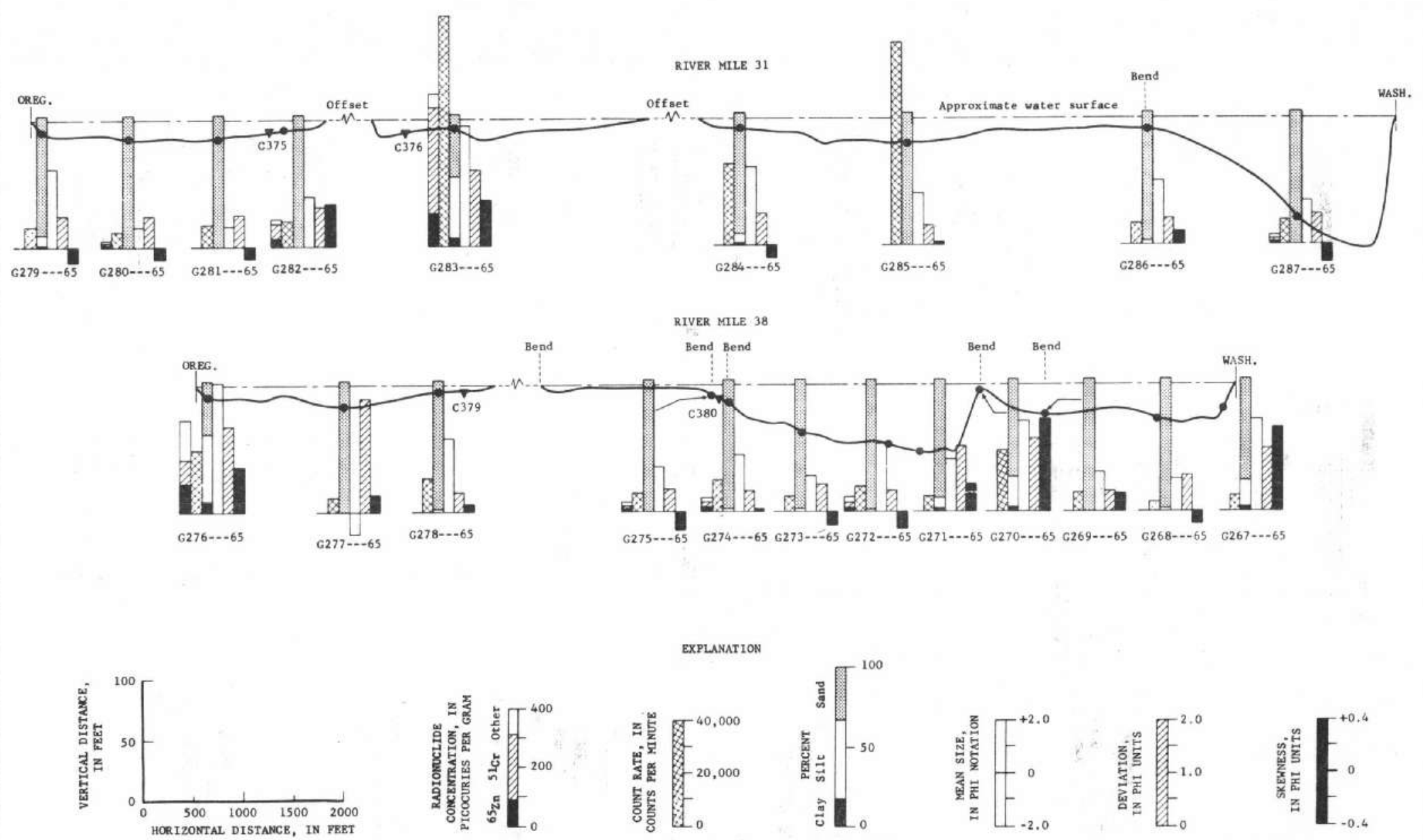

Figure 11.--Radioactivity and texture at surficial sediment sample locations in cross sections at river miles 31 and 38 . Dots and triangles on the bed profile locate positions of surficial sediment and core samples, respectively. Baseline for bar graphs is zero. Alignment of cross sections corresponds with that shown on plates 1 and 2 , and significant bends and offsets are indicated accordingly. 


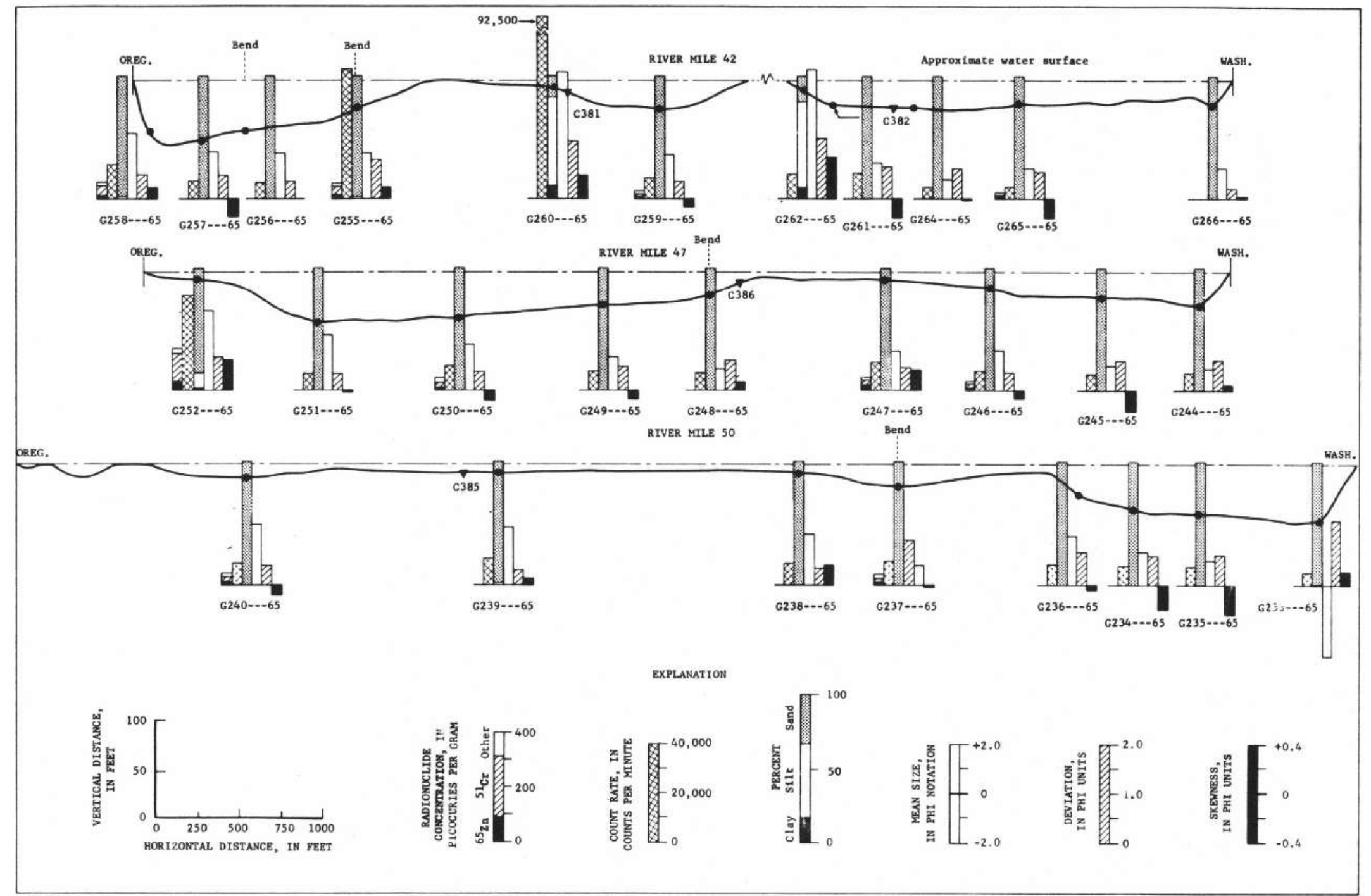

Figure 12.--Radiaactivity and texture at surficial sediment sample locations in cross sections at river miles 42,47 , and 50. Dots and triangles on the bed profile locate positions of surficial sediment and core samples, respectively. Baseline for bar graphs is zero. Alignment of cross sections corresponds with that shown on plate 1 , and significant bends are indicated accordingly. 

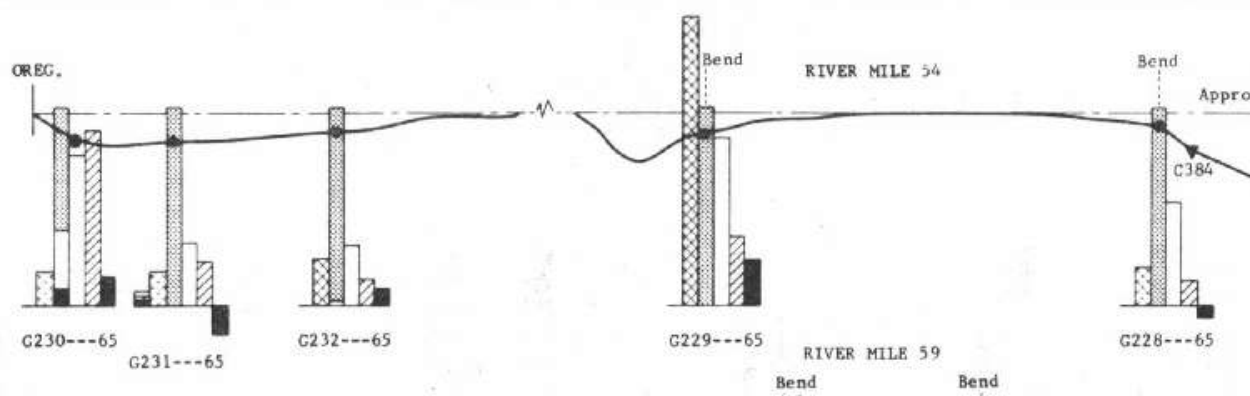

Ben

WASH.

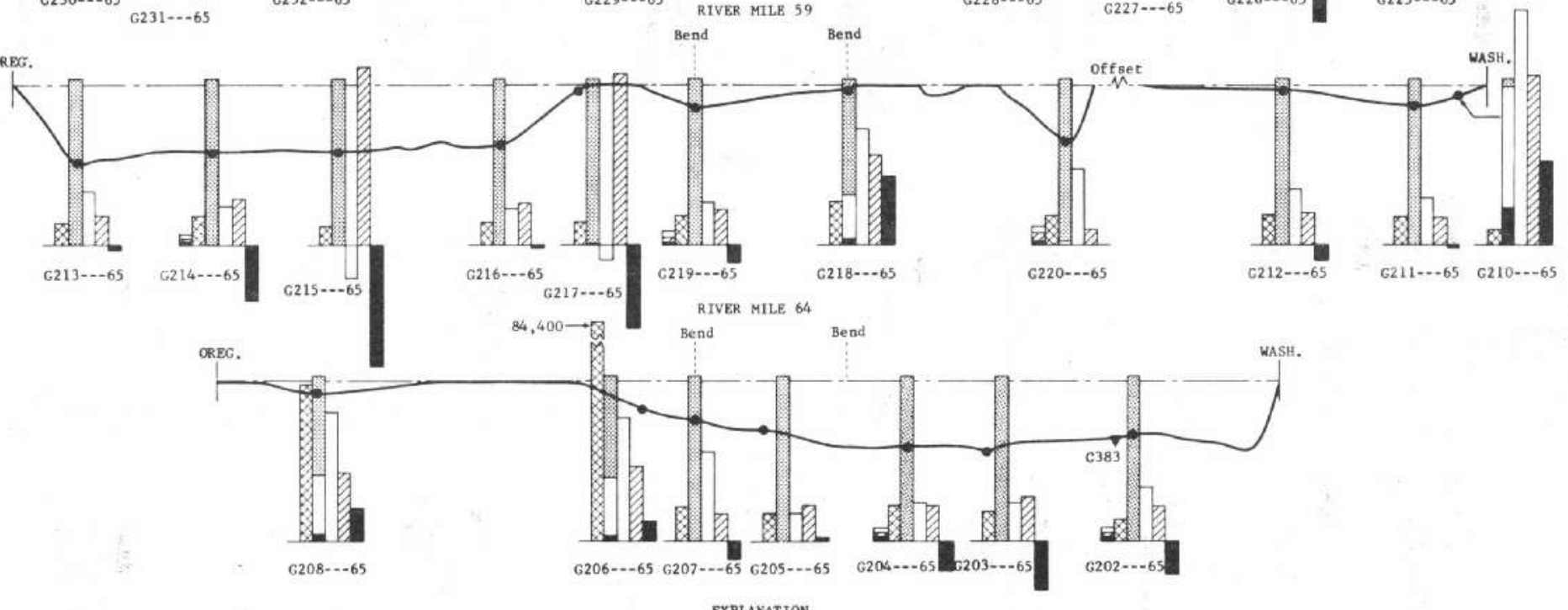

EXPLANATION
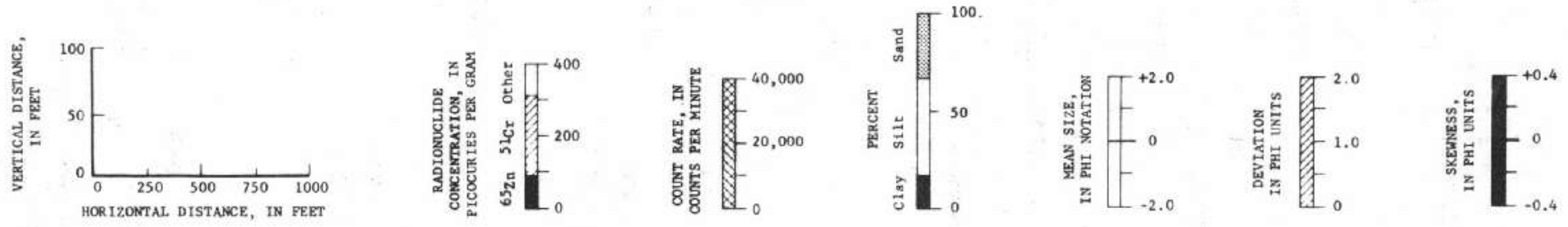

Figure 13.--Radioactivity and texture at surficial sediment sample lacations in cross sections at river miles 54, 59, and 64. Dots and triangles on the bed profile locate positions of surficial sediment and core samples, respectively. Baseline for bar graphs is zero. Alignment of cross sections corresponds with that shown on plate $I$, and significant bends and offset are indicated according $1 \mathrm{y}$. 
continually, alternately upstream and downstream. They form a continuous interwoven network throughout the estuary and are bound laterally by slope areas. Usually channels are the deepest parts of a cross section and have flat or gently sloping transverse bed profiles. Slopes are areas that are adjacent to the channels on one side and are usually bound by either the shore or a flat on the other side. They are characterized by a relatively steep transverse bed slope. Flats are areas that are perpetually shallow or periodically inundated and where flow velocities and bed slopes usually are low. Many flats are bound completely by slope areas; however, others lie between slope areas and the shore.

Average values of $\mathrm{M}_{\Phi}$ (mean grain diameter, in phi notation), $\sigma_{\Phi}$ (deviation measure, in phi units), and $\alpha_{1 \Phi}$ (skewness measure, in phi units) for samples from channels, slopes, and flats in each cross section and throughout the estuary are shown in table 1 and plotted in figure 14. These data serve not only to indicate the textural characteristics of the geomorphic classes but also to suggest changes that occur longitudinally in the estuary. The data show that channels-class samples, as a group, are coarse, moderately we11 sorted (relatively low values of $\sigma_{\Phi}$ ) and tend to have negatively skewed distributions (skewed toward coarse particles). Samples from the flats class represent the other extreme; that is, they are fine, more poorly sorted (higher values of $\sigma_{\Phi}$ ), and have positively skewed distributions (skewed toward fine particles). Samples from the slopes class are intermediate in all respects.

The plot of the variation of particle-size statistics with sample location (fig. 14) suggests several trends, some of which may be more apparent than real. For the geomorphic class, channels, $M_{\Phi}$ increases (samples become finer), $\sigma_{\Phi}$ remains relatively unchanged, and $\alpha_{1 \Phi}$ becomes 
Table 1.--Average values of $K_{\Phi}, \sigma_{\phi}$, and $\alpha_{1 \Phi}$ for various geomorphic classes at cross sections in the Columbia River estuary

\begin{tabular}{|c|c|c|c|c|c|c|c|c|c|c|c|c|c|c|c|c|}
\hline \multirow{3}{*}{$\begin{array}{l}\text { Crose } \\
\text { section } \\
\text { river } \\
\text { mile }\end{array}$} & \multicolumn{16}{|c|}{ Geomorphic class } \\
\hline & \multicolumn{4}{|c|}{ Channels } & \multicolumn{4}{|c|}{ Slopes } & \multicolumn{4}{|c|}{ Flats } & \multicolumn{4}{|c|}{ Al1 } \\
\hline & $\begin{array}{l}\text { Number } \\
\text { of } \\
\text { samples }\end{array}$ & $M_{\Phi}$ & $\sigma_{\Phi}$ & $\alpha_{1 \Phi}$ & $\begin{array}{l}\text { Number } \\
\text { of } \\
\text { samples }\end{array}$ & $M_{\Phi}$ & $\sigma_{\Phi}$ & $\alpha_{1 \Phi}$ & $\begin{array}{l}\text { Number } \\
\text { of } \\
\text { sauples }\end{array}$ & $\mathbf{M}_{\boldsymbol{\phi}}$ & $\sigma_{\Phi}$ & $\alpha_{1 \Phi}$ & $\begin{array}{l}\text { Number } \\
\text { of } \\
\text { samples }\end{array}$ & $\mathbf{M}_{\Psi}$ & $\sigma_{\Phi}$ & $\alpha_{1 \emptyset}$ \\
\hline 2 & 2 & 2.00 & 0.26 & -0.10 & 2 & 2.99 & 1.08 & +0.37 & 0 & $\cdots$ & ---- & ----- & 4 & 2.46 & 0.67 & +0.14 \\
\hline 6 & 5 & 2.47 & .98 & +.12 & 3 & 2.09 & .34 & +.08 & 8 & 3.99 & 1.31 & +0.34 & 16 & 3.16 & 1.03 & +.22 \\
\hline 14 & 4 & 2.76 & .94 & +.10 & 6 & 2.68 & .72 & +.05 & 3 & 2.31 & .32 & +.06 & 13 & 2.62 & .70 & +.07 \\
\hline 18 & 5 & 2.81 & .96 & +.11 & 4 & 2.25 & .74 & -.06 & 3 & 1.78 & .56 & +.01 & 12 & 2.36 & .79 & +.03 \\
\hline 23 & 5 & 2.23 & .77 & .00 & 8 & 2.70 & .62 & +.04 & 4 & 3.03 & .68 & +.17 & 17 & 2.64 & .68 & +.06 \\
\hline 27 & 3 & 1.77 & .49 & -.14 & 9 & 3.29 & 1.29 & +.10 & 3 & 2.55 & .37 & +.06 & 15 & 2.84 & .95 & +.04 \\
\hline 31 & 5 & 2.16 & .74 & +.10 & 2 & 2.24 & .68 & -.11 & 2 & 2.66 & .52 & -.01 & 9 & 2.29 & .68 & +.03 \\
\hline 38 & 4 & 1.18 & 1.04 & +.08 & 5 & 2.72 & .91 & +.17 & 3 & 2.41 & .73 & +.19 & 12 & 2.13 & .91 & +.14 \\
\hline 42 & 6 & 2.14 & .61 & +.02 & 4 & 1.79 & .62 & -.03 & 4 & 4.47 & 1.52 & +.14 & 14 & 2.71 & .87 & +.04 \\
\hline 47 & 4 & 1.48 & .45 & -.08 & 4 & 1.48 & .43 & -.04 & 2 & 2.38 & .56 & +.14 & 10 & 1.66 & .46 & -.02 \\
\hline 50 & 4 & .68 & .62 & -.06 & 5 & 2.14 & .50 & -.01 & 1 & 2.07 & .33 & +.16 & 10 & 1.55 & .53 & 2.01 \\
\hline 54 & 3 & 1.59 & .65 & -.22 & 4 & 3.47 & 1.14 & +.17 & 1 & 2.50 & .31 & +.08 & 8 & 2.64 & .85 & +.02 \\
\hline 59 & 6 & 1.05 & .87 & -.22 & 2 & .36 & 1.38 & -.46 & 6 & 3.92 & 1.34 & +.23 & 14 & 2.18 & 1.15 & -.06 \\
\hline 64 & 2 & 1.20 & .62 & -.25 & 5 & 2.45 & .74 & +.02 & 0 & -.-- & $\cdots$ & $-\cdots$ & 7 & 2.09 & .70 & -.05 \\
\hline Average & $\underline{1} / 58$ & 1.87 & .75 & -.02 & $\underline{1} / 63$ & 2.49 & .81 & +.04 & $\underline{1} / 40$ & 3.18 & .90 & +.17 & & & & \\
\hline
\end{tabular}




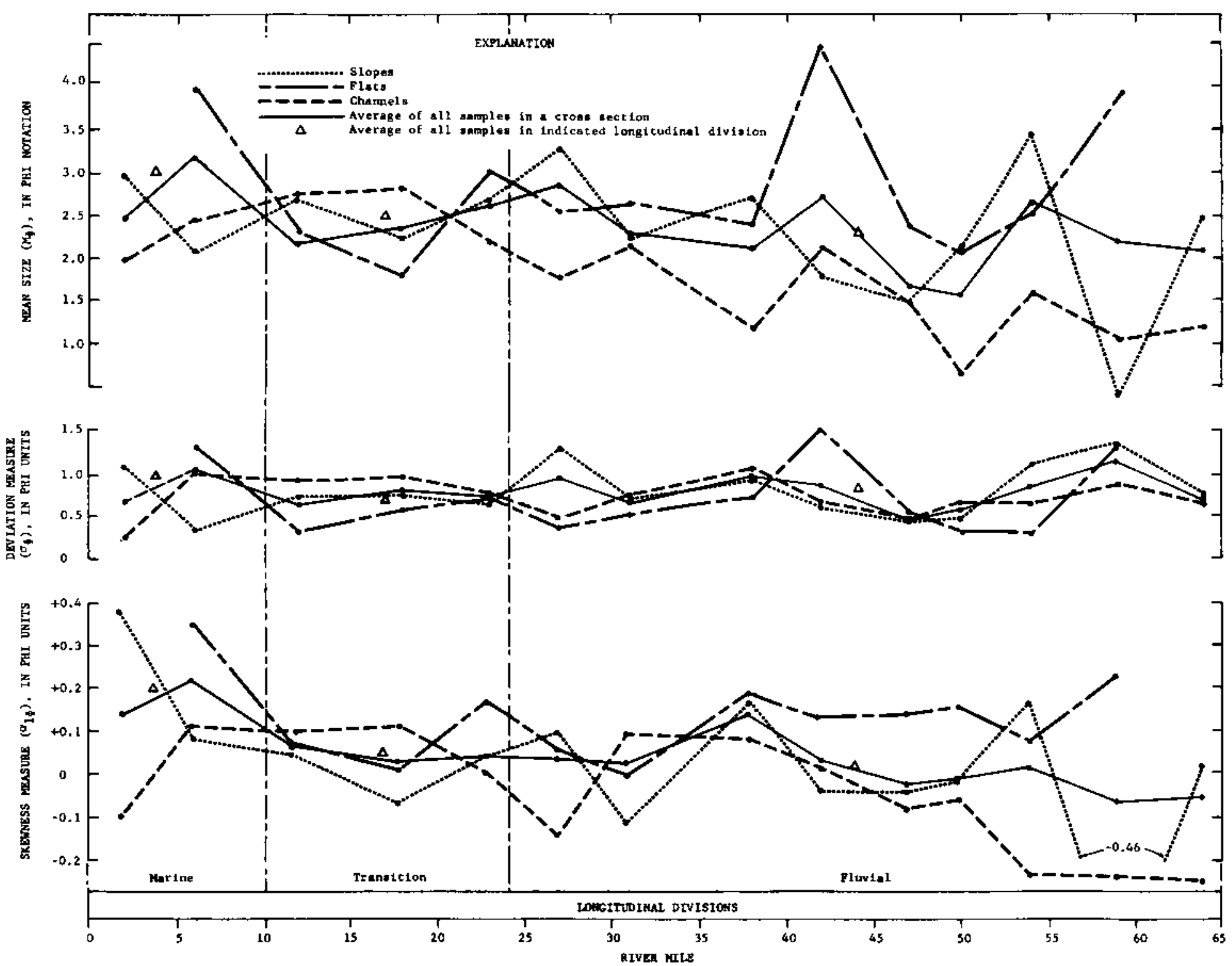

Figure 14.--Variation in average textural characteristics of surficial samples in geomorphic classes at cross sections along the Columbia River estuary. 
positive or less negative (distributions become less skewed toward coarse particles) from the head to the mouth of the estuary. The textural characteristics of the slopes and flats classes show no readily apparent significant trends along the estuary.

Some rather large among-cross-section variations in textural statistics of samples from the same geomorphic class are evident from the plots in figure 14. Because of the limited number of samples available from each cross section, it was not possible to develop a more elaborate and meaningful environmental classification. As a result, at one cross section, using data from the channels class as an example, most samples may have been obtained in a large, main channel; whereas, at another cross section, most samples may have come from one of the smaller channels. With more data, it seems likely that additional significant and mappable geomorphic classes can be delineated.

Because it was evident that too few samples (table 1) from some cross sections were analyzed, data from adjacent cross sections were combined to obtain more statistcally significant results. The results from one combination are shown in table 2. For this combination, the three cross-section classes previously discussed (channels, slopes, flats) were retained and three longitudinal divisions were established. The longitudinal divisions are termed "marine," "transition," and "fluvial" after the presumed dominant processes in each division. Although the locations of the boundaries between the divisions are somewhat subjective and vary during the year as upland flow and tides vary, for purposes of this report samples from cross sections near CRM 2 and 6 are considered as coning from the marine division; samples from cross sections near CRM 14, 18, and 23 are from the transition division; and 
Table 2.--Sumary of textural statistics of surficial sediment samples grouped according to geomorphic class and longitudinal division

\begin{tabular}{|c|c|c|c|c|c|c|c|c|c|c|c|}
\hline \multirow{3}{*}{$\begin{array}{l}\text { Longitudinal } \\
\text { dfvision }\end{array}$} & \multirow{3}{*}{$\begin{array}{l}\text { Geomorphic } \\
\text { class }\end{array}$} & \multirow{3}{*}{$\begin{array}{l}\text { Number } \\
\text { of } \\
\text { samples }\end{array}$} & \multicolumn{9}{|c|}{ Particle size statistic } \\
\hline & & & \multicolumn{3}{|c|}{$\begin{array}{c}\text { Mean grain diamater }\left(M_{\Phi}\right) \text {, in } \\
\text { phi notation }\end{array}$} & \multicolumn{3}{|c|}{$\begin{array}{c}\text { Deviation measure }\left(\sigma_{\Phi}\right) \text {, in } \\
\text { phi units }\end{array}$} & \multicolumn{3}{|c|}{$\begin{array}{c}\text { Skewness measure }\left(\alpha_{1 \Phi}\right) \text {, in } \\
\text { phi units }\end{array}$} \\
\hline & & & Range & $\begin{array}{l}\text { Aver- } \\
\text { age }\end{array}$ & $\begin{array}{l}\text { Stan- } \\
\text { dard } \\
\text { devi- } \\
\text { aţion }\end{array}$ & Range & $\begin{array}{l}\text { Aver- } \\
\text { age }\end{array}$ & $\begin{array}{l}\text { Stan- } \\
\text { dard } \\
\text { devi- } \\
\text { ation }\end{array}$ & Range & $\begin{array}{c}\text { Aver- } \\
\text { age }\end{array}$ & $\begin{array}{l}\text { Stan- } \\
\text { dard } \\
\text { devi- } \\
\text { ation }\end{array}$ \\
\hline \multicolumn{12}{|c|}{ All samples } \\
\hline Fluvial & $\begin{array}{l}\text { Channels } \\
\text { Slopes } \\
\text { Flats } \\
\text { All }\end{array}$ & $\begin{array}{l}37 \\
40 \\
22 \\
99\end{array}$ & $\begin{array}{r}-2.97 \text { to }+5.30 \\
-.47 \text { to }+6.35 \\
+1.36 \text { to }+7.08 \\
-2.97 \text { to }+7.08\end{array}$ & $\begin{array}{l}+1.51 \\
+2.46 \\
+3.22 \\
+2.27\end{array}$ & $\begin{array}{l}1.34 \\
1.52 \\
1.56 \\
1.59\end{array}$ & $\begin{array}{r}0.22 \text { to } 2.72 \\
.30 \text { to } 2.56 \\
.31 \text { to } 2.67 \\
.22 \text { to } 2.72\end{array}$ & $\begin{array}{r}0.69 \\
.88 \\
.92 \\
.82\end{array}$ & $\begin{array}{r}0.53 \\
.62 \\
.74 \\
.62\end{array}$ & $\begin{array}{r}-0.77 \text { to }+0.35 \\
-.52 \text { to }+.63 \\
-.14 \text { to }+.70 \\
-.77 \text { to }+.70\end{array}$ & $\begin{array}{r}-0.07 \\
+.03 \\
+.14 \\
+.02\end{array}$ & $\begin{array}{r}0.21 \\
.23 \\
.21 \\
.23\end{array}$ \\
\hline Trangition & $\begin{array}{l}\text { Channels } \\
\text { Slopes } \\
\text { Flats } \\
\text { All }\end{array}$ & $\begin{array}{l}14 \\
18 \\
10 \\
42\end{array}$ & $\begin{array}{r}+.97 \text { to }+5.03 \\
+1.04 \text { to }+5.17 \\
+1.07 \text { to }+5.23 \\
+.97 \text { to }+5.23\end{array}$ & $\begin{array}{l}+2.58 \\
+2.59 \\
+2.44 \\
+2.55\end{array}$ & $\begin{array}{l}1.45 \\
1.12 \\
1.11 \\
1.31\end{array}$ & $\begin{array}{l}.25 \text { to } 2.13 \\
.22 \text { to } 1.87 \\
.30 \text { to } 1.41 \\
.22 \text { to } 2.13\end{array}$ & $\begin{array}{l}.89 \\
.68 \\
.54 \\
.72\end{array}$ & $\begin{array}{l}.66 \\
.46 \\
.34 \\
.52\end{array}$ & $\begin{array}{l}-.30 \text { to }+.55 \\
-.33 \text { to }+.40 \\
-.10 \text { to }+.39 \\
-.33 \text { to }+.55\end{array}$ & $\begin{array}{l}+.07 \\
+.02 \\
+.09 \\
+.05\end{array}$ & $\begin{array}{l}.24 \\
.19 \\
.16 \\
.20\end{array}$ \\
\hline Marlne & $\begin{array}{l}\text { Channelo } \\
\text { Slopes } \\
\text { Flats } \\
\text { All }\end{array}$ & $\begin{array}{r}7 \\
5 \\
8 \\
20\end{array}$ & $\begin{array}{l}+1.55 \text { to }+5.60 \\
+1.90 \text { to }+3.81 \\
+2.03 \text { to }+5.95 \\
+1.55 \text { to }+5.95\end{array}$ & $\begin{array}{l}+2.33 \\
+2.42 \\
+3.99 \\
+3.02\end{array}$ & $\begin{array}{r}1.46 \\
.78 \\
1.41 \\
1.48\end{array}$ & $\begin{array}{l}.26 \text { to } 3.06 \\
.26 \text { to } 1.85 \\
.21 \text { to } 2.10 \\
.21 \text { to } 3.06\end{array}$ & $\begin{array}{r}.77 \\
.64 \\
1.31 \\
.96\end{array}$ & $\begin{array}{r}1.02 \\
.68 \\
.68 \\
.83\end{array}$ & $\begin{array}{l}-.13 \text { to }+.42 \\
-.07 \text { to }+.81 \\
-.10 \text { to }+.80 \\
-.13 \text { to }+.81\end{array}$ & $\begin{array}{l}+.06 \\
+.19 \\
+.34 \\
+.20\end{array}$ & $\begin{array}{l}.18 \\
.36 \\
.27 \\
.28\end{array}$ \\
\hline \multicolumn{12}{|c|}{ Excluding outliers } \\
\hline Fluvial & $\begin{array}{l}\text { Channels } \\
\text { Slopes } \\
\text { Flats }\end{array}$ & $\begin{array}{l}33 \\
36 \\
20\end{array}$ & $\begin{array}{l}-0.83 \text { to }+2.49 \\
+.84 \text { to }+5.27 \\
--- \text { No out } 1 \text { ying }\end{array}$ & $\begin{array}{l}+1.51 \\
+2.42 \\
\text { values }\end{array}$ & $\begin{array}{l}0.66 \\
1.18 \\
-.--\end{array}$ & $\begin{array}{r}0.32 \text { to } 1.48 \\
.33 \text { to } 2.36 \\
.31 \text { to } 1.67\end{array}$ & $\begin{array}{r}0.62 \\
.88 \\
.75\end{array}$ & $\begin{array}{r}0.32 \\
.58 \\
.52\end{array}$ & $\begin{array}{l}-0.32 \text { to }+0.32 \\
-.40 \text { to }+.38 \\
--- \text { No out lying }\end{array}$ & $\begin{array}{l}-0.06 \\
+.03 \\
\text { g values }\end{array}$ & $\begin{array}{r}0.14 \\
.18 \\
. .-.\end{array}$ \\
\hline Trangition & $\begin{array}{l}\text { Channels } \\
\text { slopes } \\
\text { Flats }\end{array}$ & $\begin{array}{r}11 \\
16 \\
8\end{array}$ & $\begin{array}{l}--- \text { No outlying } \\
+1.04 \text { to }+3.74 \\
+1.07 \text { to }+2.54\end{array}$ & $\begin{array}{l}\text { values } \\
+2.29 \\
+2.01\end{array}$ & $\begin{array}{l}.72 \\
.76\end{array}$ & $\begin{array}{l}.25 \text { to } 2.11 \\
.22 \text { to } 1.31 \\
.30 \text { to } .65\end{array}$ & $\begin{array}{l}.70 \\
.57 \\
.41\end{array}$ & $\begin{array}{l}.50 \\
.30 \\
.15\end{array}$ & $\begin{array}{l}-- \text { No outlying } \\
--- \text { No out lying } \\
--- \text { No out lying }\end{array}$ & $\begin{array}{l}g \text { values } \\
g \text { values } \\
8 \text { values }\end{array}$ & 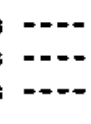 \\
\hline Marine & $\begin{array}{l}\text { Channels } \\
\text { slopes } \\
\text { Flats }\end{array}$ & $\begin{array}{r}5 \\
4 \\
--\end{array}$ & $\begin{array}{l}+1.55 \text { to }+2.02 \\
+1.90 \text { to }+2.23 \\
--- \text { No out } 1 y \text { ing }\end{array}$ & $\begin{array}{l}+1.74 \\
+2.08 \\
\text { values }\end{array}$ & $\begin{array}{r}.24 \\
.14 \\
.---\end{array}$ & $\begin{array}{c}.26 \text { to } .49 \\
.26 \text { to } .43 \\
--- \text { No out } 1 y \text { in }\end{array}$ & $\begin{array}{l}.36 \\
.34 \\
\text { values }\end{array}$ & $\begin{array}{l}.11 \\
.07 \\
---\end{array}$ & $\begin{array}{l}-.0 \text { No out lying } \\
-.07 \text { to } t .18 \\
-.- \text { No outlying }\end{array}$ & $\begin{array}{l}g \text { values } \\
+.04 \\
g \text { values }\end{array}$ & .11 \\
\hline
\end{tabular}


samples from the remaining cross sections are from the fluvial division. Whereas the actual boundaries between longitudinal divisions during the time of the survey may have been located differently, the boundaries selected above are probably more realistic in terms of the processes dominating through the year.

Severa1 observations relative to textural characteristics of channels, slopes, and flats in marine, transition, and fluvial divisions can be made from the data in table 2. Within each division: (1) Channels generally contain the coarsest sediment (lowest $M_{\Phi}$ ); (2) flats have sediment that generally is the finest (highest $M_{\Phi}$ ) and has the most positively skewed (highest $\alpha_{1 \Phi}$ ) size distribution; (3) slopes generally have sediments with particle sizes that are intermediate with respect to $M_{\Phi}$ and have the least skewed $\left(\alpha_{1 \Phi}\right.$ nearest 0$)$ size distribution; and (4) sediments in all three classes are moderately well sorted. Relative to trends in textural characteristics of geomorphic classes between the fluvial and marine divisions, data in table 2 indicate that: (1) Channel sediments in the marine division are finer and have size distributions that are more positively skewed than channel sediments in the fluvial diviston; (2) channel sediments in the transition division tend to be finer than channel sediments in either the marine or fluvial divisions; (3) slope sediments tend to have the same textural characteristics throughout the estuary but they may become slightly better sorted (more uniform) toward the estuary mouth; and (4) on flats, sediments are finer in the fluvial and marine divisions than in the transition division where extensive sand flats occur. When data for all samples in each of the three major divisions are averaged (table 2), it appears that in going from the fluvial into the marine division estuary sediments become finer 
and probably more poorly sorted, and their size distributions become more positively skewed.

Inspection of the ranges and standard deviations for the textural statistics given in table 2 shows that textures are quite variable within each geomorphic class and indicates the need for additional environmental classes.

The effect on averages and standard deviations of eliminating extreme values $1 \mathrm{~s}$ shown in the lower part of table 2. For the channels and slopes classes in the fluvial division, the two highest and the two lowest values of each size statistic were arbitrarily eliminated and new averages and standard deviations were computed. For all other geomorphic classes in each division, a statistical test (Li, 1964, p. 548-552) was employed to detect outlying values. If outliers were present, they were eliminated and the averages and standard deviations were computed from data for the remaining samples.

The statistical test, although applied to both high and low extreme values (inapplicable to both simultaneously), usually indicated that low values of each size statistic were not outliers; thus, the overall effect of eliminating outlying values was to decrease, a1though genera1ly only slightly, average values (table 2). However, the effect on standard deviations of eliminating extreme or outlying values was quite pronounced and, in some instances, standard deviations were reduced more than 50 percent (table 2). Although fairly large ranges and deviations still remain and suggest that additional environmental classes could be delineated, the above data would seem to indicate that geomorphic expression can be useful in mapping environments which have sediments that differ in texture. 
The removal of outlying values generally had little effect on relative textural trends previously described among classes and among divisions. In some instances, the trends of the sediments on the flats and slopes were interchanged as a result of removing extreme values; in no case, however, were complete reversals of trends noted.

\section{Cores}

Textural characterization of sediments in cores is both qualitative and quantitative. Immediately after the cores were collected, qualitative appraisals of gross physical characteristics were made. After the field appraisals, the cores (stili in plastic liners) were frozen in a styrofoam-1ined box that contained dry ice. The cores were then transported to the laboratory where they were kept frozen until they could be processed. As soon after collection as possible, each core was removed from cold storage and the core and 1 iner were cut into 1- or 2-inch segments. After thawing, each segment was extruded from the liner, trimmed around the margins to remove sediment that possibly was stratigraphically displaced, and visually inspected to note composition and other physical characteristics.

General qualitative field and laboratory observations for each core are sumarized in table 3. Data on geomorphic position and water depth at the time of coring indicate that core sites (figs. 7-13; p1s. 1-2) may have been overly concentrated in areas peripheral to channels and flats; thus, data for this set of cores may present a somewhat biased picture of the stratigraphic distribution of sediments and radionuclides. The following conclusions can be drawn from table 3: (1) Sediments almost invariably show easily visible evidences of stratification that is generally in the laminated to very thin-bedded categories (Ingram, 1954); 
Table 3.- Qualitative aspects of Columbia River estuary cores

\begin{tabular}{|c|c|c|c|c|c|}
\hline $\begin{array}{l}\text { Core } \\
\text { number }\end{array}$ & $\begin{array}{l}\text { Approx- } \\
\text { Imate } \\
\text { water } \\
\text { depth } \\
\text { (Eeet) }\end{array}$ & $\begin{array}{c}\text { Tatal } \\
\text { core } \\
\text { length } \\
\text { (1nches) } \\
\end{array}$ & Geoworphic position & Sedithents & Remarks \\
\hline c3 & -- & 65 & $\begin{array}{l}\text { On slope near entrance of Youngs } \\
\text { River into Columbia River. Pos- } \\
\text { a ible area of active deposition } \\
\text { of Youngo River sediment. }\end{array}$ & $\begin{array}{l}\text { Well stratified fine sand that } \\
\text { become finer with depth, Lower } \\
\text { one-third of core congigta of } \\
\text { layers of gray-black, often car- } \\
\text { bounceous, oilt with fine-sand } \\
\text { interbeds. }\end{array}$ & $\begin{array}{l}\text { Organic material is abundant } \\
\text { in vell-defingd loyers. }\end{array}$ \\
\hline$c 6$ & -- & 62 & $\begin{array}{l}\text { Exact pooition unknown. Ponafble } \\
\text { slope or flat in embayment below } \\
\text { Grays Point. }\end{array}$ & $\begin{array}{l}\text { Weli stratified brown to gray- } \\
\text { black fine gands and sandy silts } \\
\text { that grade dowmard to bandy and } \\
\text { clayey ofltg. }\end{array}$ & $\begin{array}{l}\text { Abundant brown and black } \\
\text { fibrous organic material in } \\
\text { distinct layergas well as } \\
\text { isolated fragments. }\end{array}$ \\
\hline c366 & 35 & 11 & $\begin{array}{l}\text { Gentle slope or flat margitial to } \\
\text { maln Columbia River channe } 1 \text { and } \\
\text { in genersi slack-water area oear } \\
\text { confluence of Columbia and Younga } \\
\text { Rivers. }\end{array}$ & $\begin{array}{l}\text { Well stratified blue-black silta } \\
\text { and sandy silto. }\end{array}$ & $\begin{array}{l}\text { Abundent thin layers of brom } \\
\text { co black organic material } \\
\text { acotcered throughout the core. } \\
\text { Sediments are very moigt and } \\
\text { "soupy" in behavior. }\end{array}$ \\
\hline $\begin{array}{l}\text { c367 } \\
\text { and } \\
\text { c367t }\end{array}$ & 15 & $\begin{array}{l}41 \\
41\end{array}$ & $\begin{array}{l}\text { Irregular olape murgina to maln } \\
\text { Columbia River channel. Possible } \\
\text { area of dredge-apoil accumplation. }\end{array}$ & $\begin{array}{l}\text { Irregularly atratified brown to } \\
\text { gray sands and ailts. Strata } \\
\text { not evident in upper part with } \\
\text { the exception of a fine-grained } \\
\text { top leyer. }\end{array}$ & $\begin{array}{l}\text { layers of brown organic mat- } \\
\text { ter, often agaciated with } \\
\text { gravel-gize pumice, occur in } \\
\text { lower part of core. Some } \\
\text { evidence of burrowing orga" } \\
\text { nism activity in lower part. }\end{array}$ \\
\hline c368 & 18 & 59 & $\begin{array}{l}\text { On or near boundary between smali } \\
\text { channel and steep glope. General } \\
\text { slack-water area near confluence } \\
\text { of South Channel and Prairle-Horth } \\
\text { Channeis in Cathlamet Bay. }\end{array}$ & $\begin{array}{l}\text { Well otratified green-to-gray } \\
\text { sands and gilts. Fine grained } \\
\text { gray-green top Layer. }\end{array}$ & $\begin{array}{l}\text { Layers of organic matter are } \\
\text { comiton. }\end{array}$ \\
\hline c369 & 17 & 47 & $\begin{array}{l}\text { On steep olope leading from ans } 11 \\
\text { chamel to adjacent flat near } \\
\text { Harrington Point. }\end{array}$ & $\begin{array}{l}\text { Well otratifled gray to gray- } \\
\text { black sandy silts and silty gands } \\
\text { near the surface and at depth } \\
\text { separated by middle zone of and } \\
\text { with small amounts of olit. }\end{array}$ & $\begin{array}{l}\text { Organic matter coumon in bed- } \\
\text { ding planes. Broken and } \\
\text { whole clan shell fragments } \\
\text { Bcactered throughout the core. } \\
\text { Sandy part of core shows evi- } \\
\text { dence of metivity of burrow- } \\
\text { ing organiome. }\end{array}$ \\
\hline $\mathrm{cs} 30$ & 17 & 40 & $\begin{array}{l}\text { On irregular gentle slope leading } \\
\text { from a flat to a deep channel near } \\
\text { Graye Point. Posoibly in gmall } \\
\text { chennel running parallel to the } \\
\text { slope. }\end{array}$ & $\begin{array}{l}\text { Thin, brown fine-grained top } \\
\text { layer over stratified brown sands, }\end{array}$ & $\begin{array}{l}\text { Organic fragments are scatter- } \\
\text { ed through core. Layers of } \\
\text { purdce fragments are found. }\end{array}$ \\
\hline c371 & 40 & 50 & $\begin{array}{l}\text { On olope leading frod ohallow to } \\
\text { deep portion of the North Changel } \\
\text { fuot abova Autorta Bridge. }\end{array}$ & $\begin{array}{l}\text { Fine-grained gray-black top layer } \\
\text { overlies 2-foot-thick zone of gray- } \\
\text { green sands that overlie well- } \\
\text { otratifled silts and sands. }\end{array}$ & $\begin{array}{l}\text { Organic matter layers and } \\
\text { ocattered flakes are abundant. }\end{array}$ \\
\hline c 372 & 7 & 54 & $\begin{array}{l}\text { On flat In Youngs Bay adjacent } \\
\text { to Youngs River channel. }\end{array}$ & $\begin{array}{l}\text { Fine-grained brown top layer over } \\
\text { reddish brown gtratified aande } \\
\text { that become moteled and gray be- } \\
\text { low about the } 12 \text {-1neh depth. }\end{array}$ & 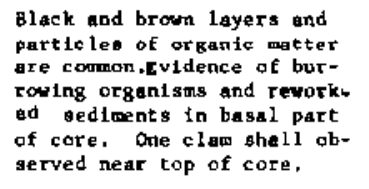 \\
\hline $\cos 73$ & 14 & 47 & $\begin{array}{l}\text { In sagll chamel with sandbar } \\
\text { across the head end and with } \\
\text { easentially iopounded flow. }\end{array}$ & $\begin{array}{l}\text { Well-stratified gray-green sands } \\
\text { and all fy sands. }\end{array}$ & $\begin{array}{l}\text { Most gtrata related to lay- } \\
\text { ered accumulation of organic } \\
\text { anter. }\end{array}$ \\
\hline 6375 & $1 / 7$ & 52 & $\begin{array}{l}\text { On margin of Clifton Channel and } \\
\text { possibly in area of gmall dunes } \\
\text { near Aldrich Point. }\end{array}$ & $\begin{array}{l}\text { Brown medium sand with silty top } \\
\text { layer. }\end{array}$ & $\begin{array}{l}\text { Strata in sand is not dis- } \\
\text { tinct except where caused } \\
\text { by rate organic layers. }\end{array}$ \\
\hline c376 & 8 & 55 & $\begin{array}{l}\text { In small slough along north gide } \\
\text { of Tenasillahe Island. Possible } \\
\text { gmall dune area. }\end{array}$ & $\begin{array}{l}\text { Gray-green fine sand with silty } \\
\text { sand top layer. Strata are pres- } \\
\text { ent but not sharply defined. }\end{array}$ & $\begin{array}{l}\text { Organic matter ccurs as } \\
\text { scattered Eragnenta. }\end{array}$ \\
\hline c377 & $\pm / 10$ & 63 & $\begin{array}{l}\text { On gentle point-bar slope and } \\
\text { possibly fn an area of sonell } \\
\text { dunes. }\end{array}$ & $\begin{array}{l}\text { Gray green to gray black fine to } \\
\text { very fine sands with interlayer } \\
\text { silt beds. Strata } 11 \text { defined. }\end{array}$ & $\begin{array}{l}\text { Organic-matter layers com- } \\
\text { mon. }\end{array}$ \\
\hline
\end{tabular}


Table 3.--Qualitative aspects of columbla River estwary cores+-Continued

\begin{tabular}{|c|c|c|c|c|c|}
\hline $\begin{array}{l}\text { Core } \\
\text { number }\end{array}$ & $\begin{array}{l}\text { Approx- } \\
\text { Imate } \\
\text { vater } \\
\text { depth } \\
\text { (feet) }\end{array}$ & $\begin{array}{c}\text { Total } \\
\text { core } \\
\text { length } \\
\text { (1nches) }\end{array}$ & Geomorphic position & Sedimentg & Remarka \\
\hline c378 & 31 & 63 & $\begin{array}{l}\text { In omall channel with sandbar } \\
\text { across lower end, Essentially } \\
\text { a "dead" channel. }\end{array}$ & $\begin{array}{l}\text { Well otratified gray-black gandy } \\
\text { silto overlying unifort fine } \\
\text { sands that coarsen with depth. }\end{array}$ & $\begin{array}{l}\text { Organic-matter layer con- } \\
\text { mon in upper part of core. } \\
\text { Scattered organic particles } \\
\text { occur ta lower port. }\end{array}$ \\
\hline 0379 & $1 / 4$ & $\mathrm{SB}$ & $\begin{array}{l}\text { On gentle slope or flat near } \\
\text { margin of Clifton Channel. }\end{array}$ & $\begin{array}{l}\text { Well gtratified gray-black silts } \\
\text { and brown ganda. }\end{array}$ & $\begin{array}{l}\text { Organic-nutter layers wide- } \\
\text { spreas. }\end{array}$ \\
\hline c380 & 18 & 47 & $\begin{array}{l}\text { Exact position unknown. Prob- } \\
\text { ably tn area of recent deposi- } \\
\text { tion downtream from new groin. }\end{array}$ & $\begin{array}{l}\text { Fine, brown sands with scattered } \\
\text { silt layers and a Bilty cap layer. }\end{array}$ & Organic matter rare. \\
\hline c381 & $1 / 6$ & 64 & $\begin{array}{l}\text { On flat adjacent to small slough } \\
\text { in which flow has been restricted } \\
\text { by relatively new river-control } \\
\text { atructures. }\end{array}$ & $\begin{array}{l}\text { Will-gtratifled brom sands and } \\
\text { gray-black silti. }\end{array}$ & $\begin{array}{l}\text { Hany layers of brown organic } \\
\text { fragments throughout core. } \\
\text { Some lndication of sediment } \\
\text { diaruption by burrowing } \\
\text { organisme. }\end{array}$ \\
\hline $\mathrm{C} 382$ & 23 & 23 & $\begin{array}{l}\text { On crest of } 7 \text {-foot dune in Cath- } \\
\text { lamet Channel. }\end{array}$ & $\begin{array}{l}\text { Clean, brown, mediun sand, Strata } \\
\text { not evident. }\end{array}$ & Organic matter absent. \\
\hline c383 & 41 & 11 & $\begin{array}{l}\text { Probably in poorly consolidated } \\
\text { gedimentary bedrock in main } \\
\text { channel near Longutew. }\end{array}$ & $\begin{array}{l}\text { Compacted, gray, clayey silts } \\
\text { with soue thin sand layers. }\end{array}$ & $\begin{array}{l}\text { Black fragments of organic } \\
\text { matter and ganll branches } \\
\text { pretent. }\end{array}$ \\
\hline $\mathrm{C} 384$ & -- & 48 & $\begin{array}{l}\text { Exact position unknown, but } \\
\text { probably near boundary between } \\
\text { slope and flat, }\end{array}$ & $\begin{array}{l}\text { clean, fine, brown sand below a } \\
\text { thin, gilty cap layer. Grades } \\
\text { downmard into medium sands with } \\
\text { gome interbeds of ailt. }\end{array}$ & $\begin{array}{l}\text { Organic anterial is rare } \\
\text { and occurs as thin layers. }\end{array}$ \\
\hline C385 & $1 / 10$ & 42 & $\begin{array}{l}\text { Small channel in an area of } 2 \text { - } \\
\text { foot dunes. Possible area of } \\
\text { recent accretion due to maln- } \\
\text { channel control btructures. }\end{array}$ & $\begin{array}{l}\text { Clean, brow, fine sand that } \\
\text { coarsens slightly with depth, } \\
\text { with silty top layer. Faint } \\
\text { textural stratificetion. }\end{array}$ & $\begin{array}{l}\text { Only a few acattered frag- } \\
\text { ments of brown organic } \\
\text { material. }\end{array}$ \\
\hline c386 & -- & 58 & $\begin{array}{l}\text { Exact position unkgown; probably } \\
\text { on slope near boundary with ad } \\
\text { Jacent flat. May be in recent } \\
\text { dredge-apoil area. }\end{array}$ & $\begin{array}{l}\text { clean, greenish brown to gray } \\
\text { medium ands that coarsen with } \\
\text { depth. Strate, due to thin } \\
\text { layers of pumice fragments, con- } \\
\text { mon in lower part of core. }\end{array}$ & $\begin{array}{l}\text { Organic material as brown } \\
\text { scattered feggents. }\end{array}$ \\
\hline $\begin{array}{l}\text { c387 } \\
\text { and } \\
\text { c387 I }\end{array}$ & $\begin{array}{l}25 \\
25\end{array}$ & $\begin{array}{l}46 \\
30\end{array}$ & $\begin{array}{l}\text { On gentle olope, almost a flat, } \\
\text { in sheltered area between the } \\
\text { not th jetty and Cape Disappoint- } \\
\text { ment. }\end{array}$ & $\begin{array}{l}\text { Doninantly clean, green, fine } \\
\text { send with gray-biack oilty top } \\
\text { layer and a few ailty layerg at } \\
\text { depth. Strata faint but preg- } \\
\text { ent. }\end{array}$ & $\begin{array}{l}\text { Organic matter layerg and } \\
\text { scettered fragnents are } \\
\text { predent but not abundant. }\end{array}$ \\
\hline c388 & 16 & 66 & $\begin{array}{l}\text { In soull charnel with srooth bot- } \\
\text { ton. }\end{array}$ & $\begin{array}{l}\text { Well stratifled sandy and clayey } \\
\text { black afles. }\end{array}$ & $\begin{array}{l}\text { Organic mater layers are } \\
\text { common. Shell fragonts } \\
\text { and tome evidence of ac- } \\
\text { tivity of burrowing organ- } \\
\text { lam. }\end{array}$ \\
\hline $\mathrm{c} 389$ & 8 & 52 & T1dal flat. & $\begin{array}{l}\text { Stratified clean gray-green fine } \\
\text { gands vith a top allty layer and } \\
\text { occagional gilty layer at depth. }\end{array}$ & $\begin{array}{l}\text { Soull, Bcattered, brown } \\
\text { organic-matter fragments } \\
\text { occur in the lower part of } \\
\text { the core, A living clam } \\
\text { wa found in the upper } \\
\text { part of the core. }\end{array}$ \\
\hline
\end{tabular}

lif Botimated. 
(2) sediment color varies with texture, with geographic location and, predictably, with depth, from brown to green to gray and black; (3) sediments are chiefly sands with varying but moderate amounts of interbedded silts; (4) a fine-grained, generally thin, top layer caps many cores, even those that contain little fine sediment at depth; and (5) organic matter, either as layers or as isolated fragments, occurs in most cores.

Genera1 aspects of the stratigraphy in Columbia River estuary cores are illustrated in figure 15. Although the cores shown (fig. 15) were collected at an earlier date than those described herein, their geomorphic positions and stratigraphic sequences are nearly identical to those for cores $\mathrm{C} 368$ and $\mathrm{C} 369$ (p1. 2). Alternating layers of sand (1ight color) and silt, mostly horizontal but, in part, inclined and resembling cross bedding, are obvious as is disruption of strata due to burrowing organisms. Some warping caused by the corer is also apparent and is particularly noticeable where sediments are fine grained.

Quantitative textural data for selected segments from each core.were obtained after the segments had been analyzed for radionuclides. Because segments were dried prior to radionuclide analyses, the textural data may not be exactly comparable with data from surficial sediments, which were analyzed without prior drying. Also, for those segments analyzed by the pipette method, only two sizes (16 micron and 4 micron) were determined. In general, textural data for core segments are less reliable than similar data for surficial sediments.

The selection of segments to be analyzed for size was based on two considerations; results from radionuclide analyses, and visual observation of the overall stratigraphic characteristics of the core. To 


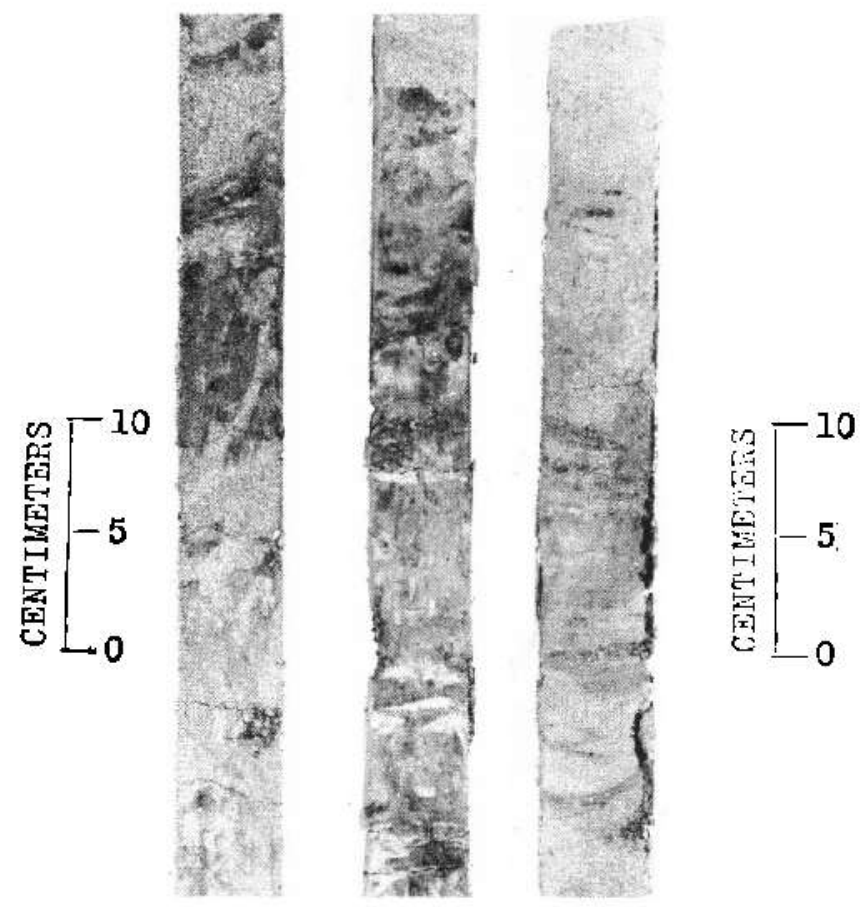

A. Parts of the bottom, middle, and top (left to right) of a core obtained near C368.

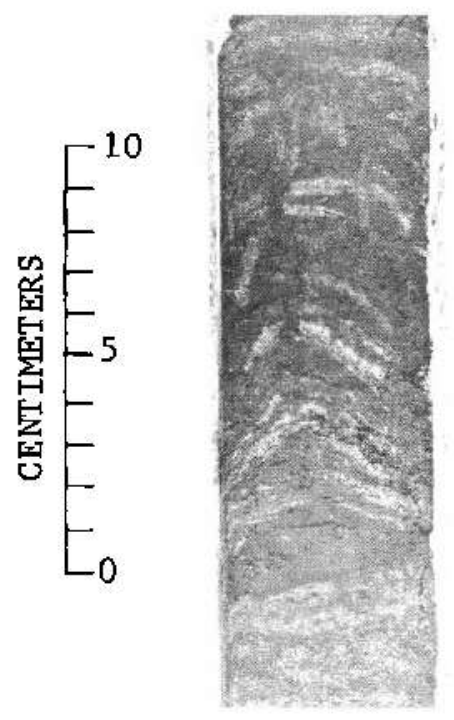

B. Section showing alternating coarseand fine-grained strata in a core obtained near $\mathrm{C} 369$.

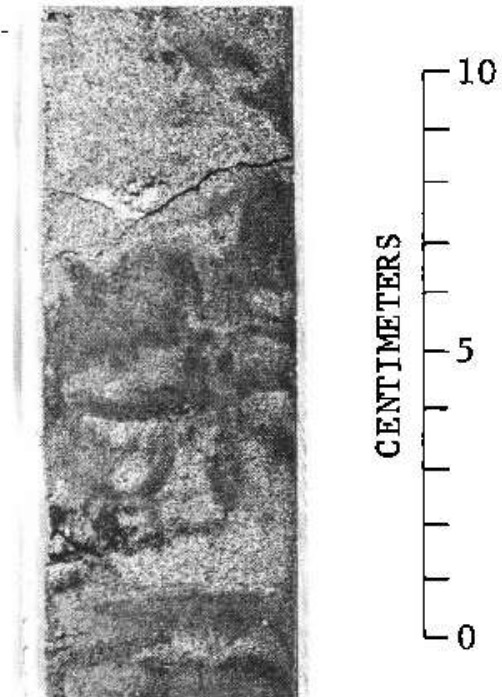

C. Section of sandy core showing effects of burrowing organisus. Core obtained near. C369.

Figure 15.--Longitudinal sections of cores collected in the Columbia River estuary, east of Tongue Point, Oreg. (From Prych and Hubbell, 1966, pl. 2.) 
characterize the stratigraphy of the core, it was generally possible to select for size analyses segments that had been used in delineating the distribution of radionuclides in the core. However, for some cores, particularly those in which only 2 or 3 segments were analyzed for either radionuclides or size, the results may be somewhat misleading.

Particle-size distribution statistics for 147 segments from cores are shown in appendix II and selected statistics are sumarized in figure 16. In this figure if percentages of silt and clay had not actualiy been determined (app. II), they were estimated from the average ratio of silt to clay determined for other segments in the core, or if no other segments in a core had been analyzed, they were estimated from the average ratio of silt and clay in surficial sediments (p. 23). The results from either technique genera11y were only slightly different.

Comparison of sand-silt-clay ratios (fig. 16A) for core segments with similar ratios for surficial sediments (fig. 6) generally reveals a similarity in their distributions. As with surficial sediments, core segments are chiefly sand with some silt and clay. Sand is by far the dominant texture class; the next most frequent class is silty sand (fig. 16B). Although sandy silt is a prevalent class in surficial sediments, finer classes tend to be more important in the core segments. In genera1, it appears that sediments in core segments are somewhat finer than surficial sediments. Whether this reflects a biased selection of segments, a biased distribution of cores, different analytical techniques, or truly indicates that sediments are finer with depth, is unknown. A possible bias in the areal distribution of cores already has been suggested and, because the textures of segments at the tops of the cores are usually finer than the texture at depth (app. II), it seems 


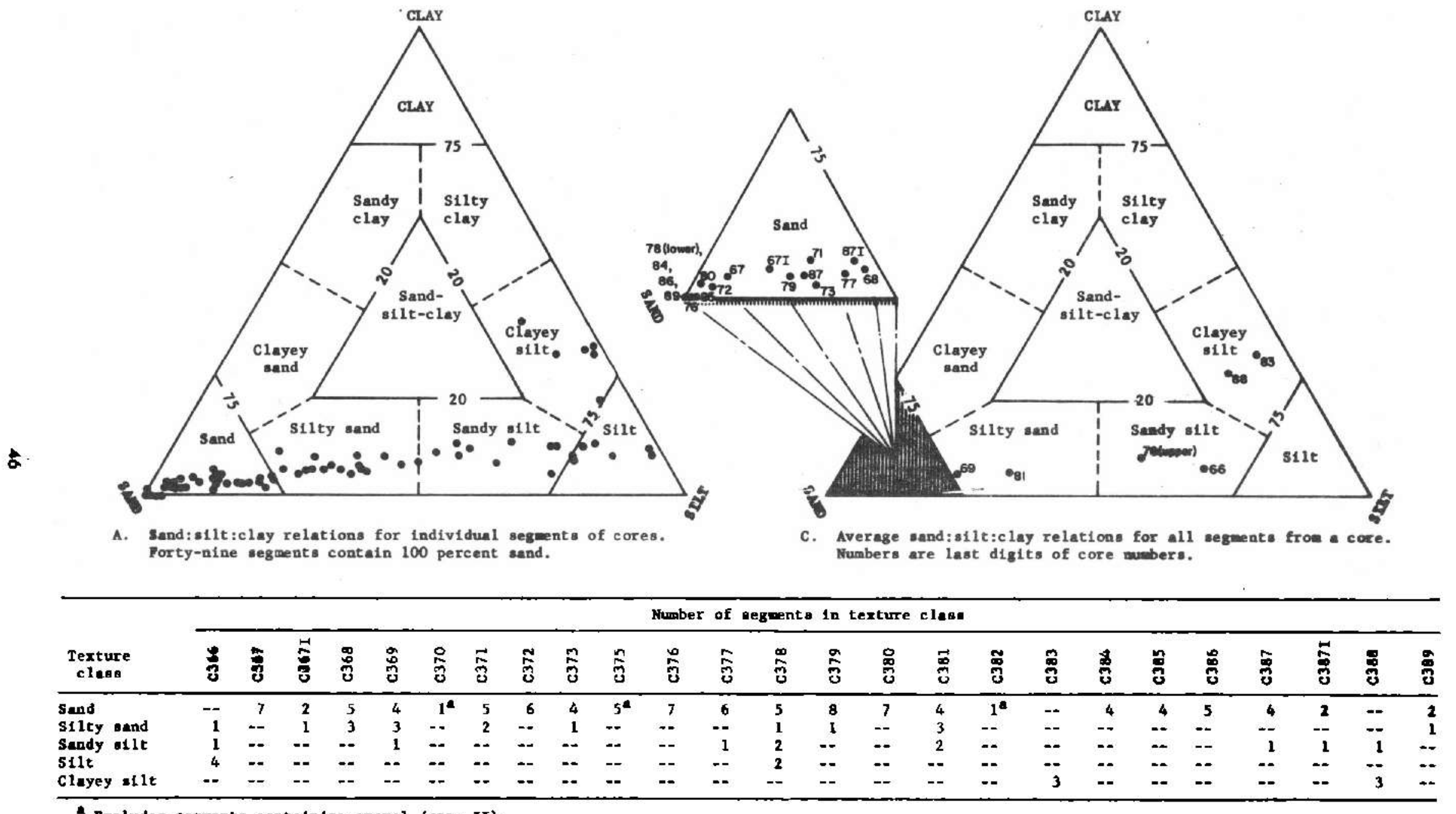

axcludes aegmenta contalning gravel (app. II).

B. Clasafication of segments from cores into texture clases (Shepard, 1954).

Figure 16.--Textural characteristics of Columbia River eatuary cores. 
most 1 ikely that the cores are generally representative of environments having finer-grained sediments than the environments represented by the surficial sediment samples.

Average size statistics for sediments of each core are shown in table 4 and figure 16C. The relatively large standard deviations reveal the wide range of texture that exists within a core and comparison of average size statistics reveals large differences anong cores. The average of the mean grain size among cores varied from a phi value of 7.00 (about $0.008 \mathrm{~mm}$ ) to 1.24 (about $0.423 \mathrm{~mm}$ ), and, in one core (C378), the average for segments from the upper 10 inches is more than twice the average from segments lower in the core. Even larger within-core textural differences exist in sand cores that had a single, fine-grained top layer--a not infrequent occurrence. Overall, sediments from core segments have an average mean grain size in the fine-sand range (Wentworth, 1922), are moderately well sorted and have size distributions that tend to be slightly positively skewed. In only 5 cores are the sediments sufficiently fine grained throughout to fall in other than the sand-texture class (fig. 16C).

Stratigraphic variations in mean grain size and deviation measure are shown in figure 17. Although it is difficult to generalize at this point about the variations, when quantitative data are combined with qualitative data pertaining to locations of cores and physical characteristics of al1 core segments, some general patterns emerge relative to sedimentation characteristics and environments. In terms of channels, flats, and slopes, the three geomorphic divisions utilized to sumnarize surficial sediment data, the core data tend to indicate a stratigraphic homogeneity (at least in the upper few feet) in channels, but stratigraphic 
Table 4.--Sumary of average cextural characteristac of care fron the Columbla River eatuny

\begin{tabular}{|c|c|c|c|c|c|c|c|c|c|c|c|c|c|c|c|}
\hline \multirow[b]{4}{*}{$\begin{array}{l}\text { Core } \\
\text { number }\end{array}$} & \multirow[b]{4}{*}{$\begin{array}{l}\text { Number of } \\
\text { segments } \\
\text { analyzed }\end{array}$} & \multicolumn{6}{|c|}{ Particle-oize otatiotic } & \multirow{2}{*}{\multicolumn{8}{|c|}{ Textural dietribution, in percent }} \\
\hline & & \multirow{2}{*}{\multicolumn{2}{|c|}{$\begin{array}{c}\text { Mesn gratn } \\
\text { diameter }\left(M_{4}\right) \text {, } \\
\text { in } \\
\text { ghi notation }\end{array}$}} & \multirow{2}{*}{\multicolumn{2}{|c|}{$\begin{array}{l}\text { Devietion } \\
\text { mosure } \\
\left(\sigma_{1}\right) \text {, in } \\
\text { phi unita }\end{array}$}} & \multirow{2}{*}{\multicolumn{2}{|c|}{$\begin{array}{l}\text { Skewneso } \\
\text { measure } \\
\left(\alpha_{21}\right)_{3} \text { in } \\
\text { phi uniks }\end{array}$}} & & & & & & & & \\
\hline & & & & & & & & \multicolumn{2}{|c|}{ Grevel } & \multicolumn{2}{|c|}{ Sand } & \multicolumn{2}{|c|}{ S11t } & \multicolumn{2}{|c|}{ clay } \\
\hline & & $\begin{array}{l}\text { Aver- } \\
\text { age }\end{array}$ & $\begin{array}{l}\text { Sean- } \\
\text { dard } \\
\text { devi- } \\
\text { ation }\end{array}$ & $\begin{array}{c}\text { Aver- } \\
\text { age }\end{array}$ & $\begin{array}{l}\text { Stan- } \\
\text { dard } \\
\text { devi- } \\
\text { arion }\end{array}$ & $\begin{array}{l}\text { Aver - } \\
\text { age }\end{array}$ & $\begin{array}{l}\text { Stan- } \\
\text { derd } \\
\text { devi- } \\
\text { ation }\end{array}$ & $\begin{array}{l}\text { Aver- } \\
\text { age }\end{array}$ & $\begin{array}{l}\text { Stan- } \\
\text { derd } \\
\text { devi- } \\
\text { ation }\end{array}$ & $\begin{array}{l}\text { Aver- } \\
\text { age }\end{array}$ & $\begin{array}{l}\text { Stan- } \\
\text { dard } \\
\text { devi- } \\
\text { ation }\end{array}$ & $\begin{array}{c}\text { Aver: } \\
\text { age }\end{array}$ & $\begin{array}{l}\text { Stan- } \\
\text { derd } \\
\text { devi- } \\
\text { ation }\end{array}$ & $\begin{array}{c}\text { Aver- } \\
\text { age }\end{array}$ & $\begin{array}{l}\text { Stan- } \\
\text { dard } \\
\text { devi- } \\
\text { ation }\end{array}$ \\
\hline$c 366$ & $1 / 4$ & 4.85 & 0.46 & 1.30 & 0,36 & 0.09 & 0.02 & $-\cdots$ & $\cdots+$ & 27 & 15.7 & 67 & 15.4 & 6 & 17.1 \\
\hline c367 & 7 & 2.02 & .33 & ss & .17 & .01 & .25 & $\cdots+$ & $\cdots \cdots$ & $\$ 4$ & 6.0 & 4 & 3.9 & 2 & 1.9 \\
\hline 63671 & 3 & 2.60 & 1.30 & 1.00 & .30 & .06 & .51 & ---- & $\cdots$ & 88 & 20.2 & 9 & 15.6 & 3 & 14.6 \\
\hline C368 & a & $3.5 \mathrm{a}$ & .52 & .79 & .41 & .23 & .23 & ---- & ---- & 79 & 16.6 & 18 & 24.1 & 3 & 2.5 \\
\hline$c 369$ & 8 & 3.56 & 1.05 & 1.00 & .56 & .16 & .14 & $\cdots$ & $\ldots$ & 74 & 25.5 & 22 & 21.6 & 4 & 3.9 \\
\hline $\mathrm{c} 370$ & 5 & 1.31 & .45 & .83 & .30 & -.24 & .27 & 5 & 6.2 & 95 & 6.2 & $--n$ & $-=-$ & --1 & $\cdots$ \\
\hline $\cos 1$ & 7 & 3.12 & 1.38 & 1.44 & 1.41 & .29 & .42 & $\ldots$ & $-\cdots$ & 83 & 15.9 & 13 & 12.6 & 4 & 3.5 \\
\hline $\mathrm{c} 372$ & 6 & 2.69 & .22 & .42 & .17 & .15 & .19 & ---- & 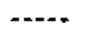 & 96 & 6.0 & 3 & 12.6 & 1 & 2.1 \\
\hline c373 & 5 & 3.54 & .43 & .57 & .34 & .21 & .19 & $\ldots$ & $\ldots$ & 84 & 15.7 & 15 & 14.1 & 1 & 1.7 \\
\hline c375 & 7 & 1.84 & .38 & .74 & .19 & .11 & .14 & 1 & 1 & 99 & 1.6 & $=--$ & --. & ----- & $\cdots$ \\
\hline 0376 & 7 & 2.68 & .10 & .38 & .07 & .12 & .12 & $-\cdots$ & $\cdots$ & 99 & .9 & 1 & .9 & ---- & ---- \\
\hline 0377 & 7 & 3.50 & .83 & .82 & .55 & .24 & .16 & $\cdots$ & $\ldots$ & 81 & 20.8 & 16 & 17.1 & 3 & 3.8 \\
\hline C 378 & $\frac{2}{3} / 6$ & $\begin{array}{l}4.78 \\
2.29\end{array}$ & $\begin{array}{r}1.06 \\
.64\end{array}$ & $\begin{array}{r}1.29 \\
.51\end{array}$ & $\begin{array}{r}.41 \\
.19\end{array}$ & .02 & $\begin{array}{l}.16 \\
.08\end{array}$ & 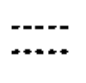 & ----- & $\begin{array}{r}38 \\
100\end{array}$ & $\begin{array}{c}31.4 \\
0\end{array}$ & 54 & 28,0 & B & 3.5 \\
\hline c379 & 9 & 3.24 & .57 & .73 & .41 & .24 & .25 & $\cdots$ & 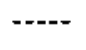 & 88 & 11.4 & 10 & 9.4 & 2 & 2.0 \\
\hline $\mathrm{c} 380$ & 7 & 2.54 & .25 & .44 & .12 & .09 & .11 & --- & $=---$ & 97 & 4.5 & 2 & 3.8 & 1 & .8 \\
\hline c381 & 9 & 3.96 & .72 & .89 & .43 & .22 & .21 & --- & --- & 64 & 27.9 & 32 & 24.6 & 4 & 3.3 \\
\hline$c 382$ & 5 & 1.24 & .11 & $: 58$ & .07 & -.06 & .01 & 1 & .8 & $9 B$ & 2.0 & 1 & 1.8 & ---- & $-\cdots$ \\
\hline $\mathrm{C} 3 \mathrm{B3}$ & 12 & 7.00 & .20 & 2.03 & .17 & .04 & .07 & $-\cdots$ & - - & 6 & 4.2 & 64 & 3.6 & 30 & 1.0 \\
\hline c384 & 4 & 1.82 & 39 & .49 & .11 & -.06 & .07 & $=--$ & ---- & 100 & 0 & $\cdots-$ & w. & $\ldots$ & $\ldots$ \\
\hline c38s & 4 & 2.30 & .19 & .91 & .06 & .02 & .12 & -+- & --- & 98 & 4.0 & 2 & 4.0 & $-\cdots$ & $\cdots$ \\
\hline C.386 & 5 & 1.76 & .17 & .45 & .09 & -.05 & .08 & $\ldots+$ & -a+. & 100 & 0 & $\ldots+$ & $+\infty$ & $\cdots$ & $\cdots$ \\
\hline c387 & 5 & 2.82 & .95 & .71 & .78 & .70 & .15 & $-\cdots$ & --- & 87 & 25.4 & 11 & 21.5 & 2 & 3.9 \\
\hline C387I & 3 & 3.10 & 1.53 & .80 & .91 & .02 & .09 & $-+-=$ & $-\cdots$ & 78 & 37.5 & 18 & 31.6 & 4 & 5.8 \\
\hline $\mathrm{C} 3 \mathrm{BB}$ & 13 & 6.39 & .87 & 2.57 & .53 & .13 & .28 & ---- & ---- & 13 & 7.5 & 61 & 11.7 & 26 & 9.8 \\
\hline c389 & $1 / 2$ & 2.13 & 0 & .22 & 0 & -.06 & 0 & --- & --- & 100 & 0 & $-n$ & $\cdots$ & $\ldots$ & $\cdots$ \\
\hline
\end{tabular}

Lexcludes vegment, with poorly defined or miesing size atatistics (app. II),

2 Segment from 0 - 10 inches below surfece.

3 Segment 8 from 11 - 58 inches below aurface. 


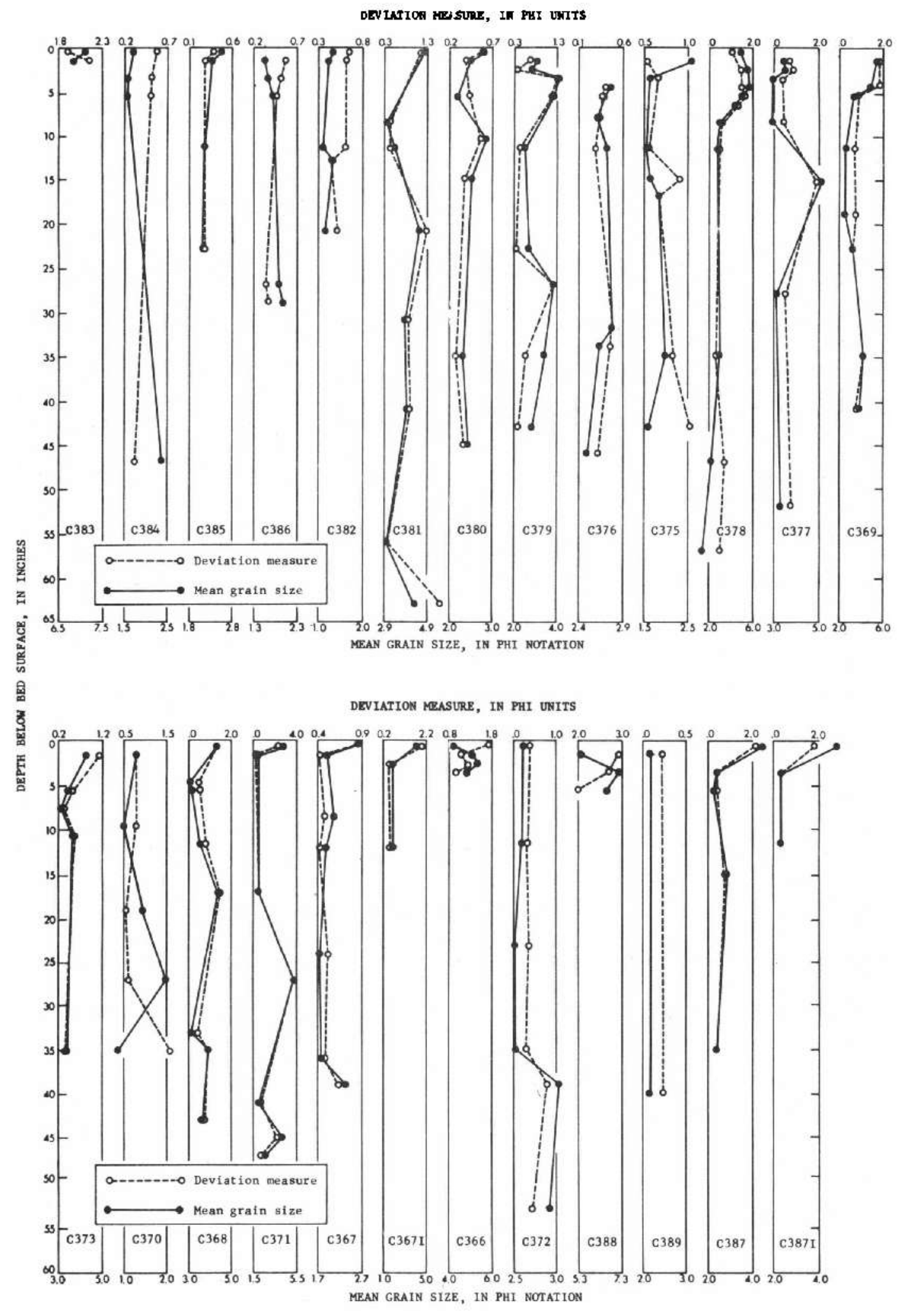

Figure 17.--Vertical distribution of mean particle size and deviation measure in cores from the Columbia River estuary. 
complexities on slopes and flats. It is anticipated that additional core data will allow classification of stratigraphic environments that quite possibly can be recognized by geomorphic criteria in most fluvialestwarine systems.

\section{RADIOACTIVITY IN BOTTOM SEDIMENTS}

Radioactivity data include gross-gamma count rates from in situ measurements of the streambed, gross-gamma count rates from laboratory measurements of surficial sediment samples, and concentrations of 5 to 8 individual gamma-emitting radionuclides from spectrometry measurements of sediment samples by the Battelle-Northwest Radiochemical Laboratory. A total of 187 in situ gross-gamma measurements were made, and 59 samples, which were collected in conjunction with the in situ measurements, were counted later in the project laboratory. The concentrations of individual radionuclides were determined from 71 selected surficial samples and from selected segments of 27 cores. These concentrations, together with concentration totals, radionuclide ratios, and in situ count rates at the sampling locations are presented for the surficial sediment samples in appendix III and for the core segments in appendix IV. An explanation of the content of these appendixes is given on page 61 . On the average, in every 10 square miles of the estuary, in situ gross-gamma measurements were made at about nine locations, radionuclide concentra* tions were determined at three locations from surficial sediment samples, and radionuclide concentrations were measured in segments from one core.

\section{Gross-Gamma Radioactivity}

In order to utilize effectively the relatively large number of in situ gross-gamma measurements and to optimize the usefulness of a11 radioactivity data, relations between gross-gamma count rates and 
radionuclide concentrations were developed. To supplement this effort, gross-gamma radioactivity in some surficial sediment samples was determined in the project laboratory prior to sending the samples to the Battelle-Northwest Radiochemical Laboratory for detailed radionuclide analyses. In the project laboratory, it was possible to calibrate and to maintain the detection system under more uniform conditions of electronic stability and of sample geometry than were experienced in field operations.

Comparisons among field (in situ) count rates, laboratory count rates, and radionuclide concentrations in surficial samples are shown in figure 18. As expected, the plot of field versus laboratory count rate (fig. 18A) shows considerable scatter although a definite relation is evident. Only about 5-10 percent of the data points are so far removed from the trend of the points as to indicate possible errors. Plots of laboratory count rates versus both $65 \mathrm{Zn}$ concentrations (fig. 18B) and the total of measured radionuclide concentrations, including ${ }^{40} \mathrm{~K}$ (fig. 18C), generally indicate better relations than the relation between field and laboratory count rates. However, even in these graphs, 2 to 5 percent of the data points are removed somewhat from lines that could be drawn to depict general relations.

The variation of in situ count rates with the total of measured radionuclide concentrations (including ${ }^{40} \mathrm{~K}$ ) in surficial samples is shown in figure 19--the relation is fairly well defined. Scatter in this data and that shown in figure $18 \mathrm{~A}$ resulted in part from counting differences that occurred because of (1) variations in counting geometry due to different vertical distributions of radionuclides in the bed and to positioning of the sled, and (2) differential adsorption of radiation 


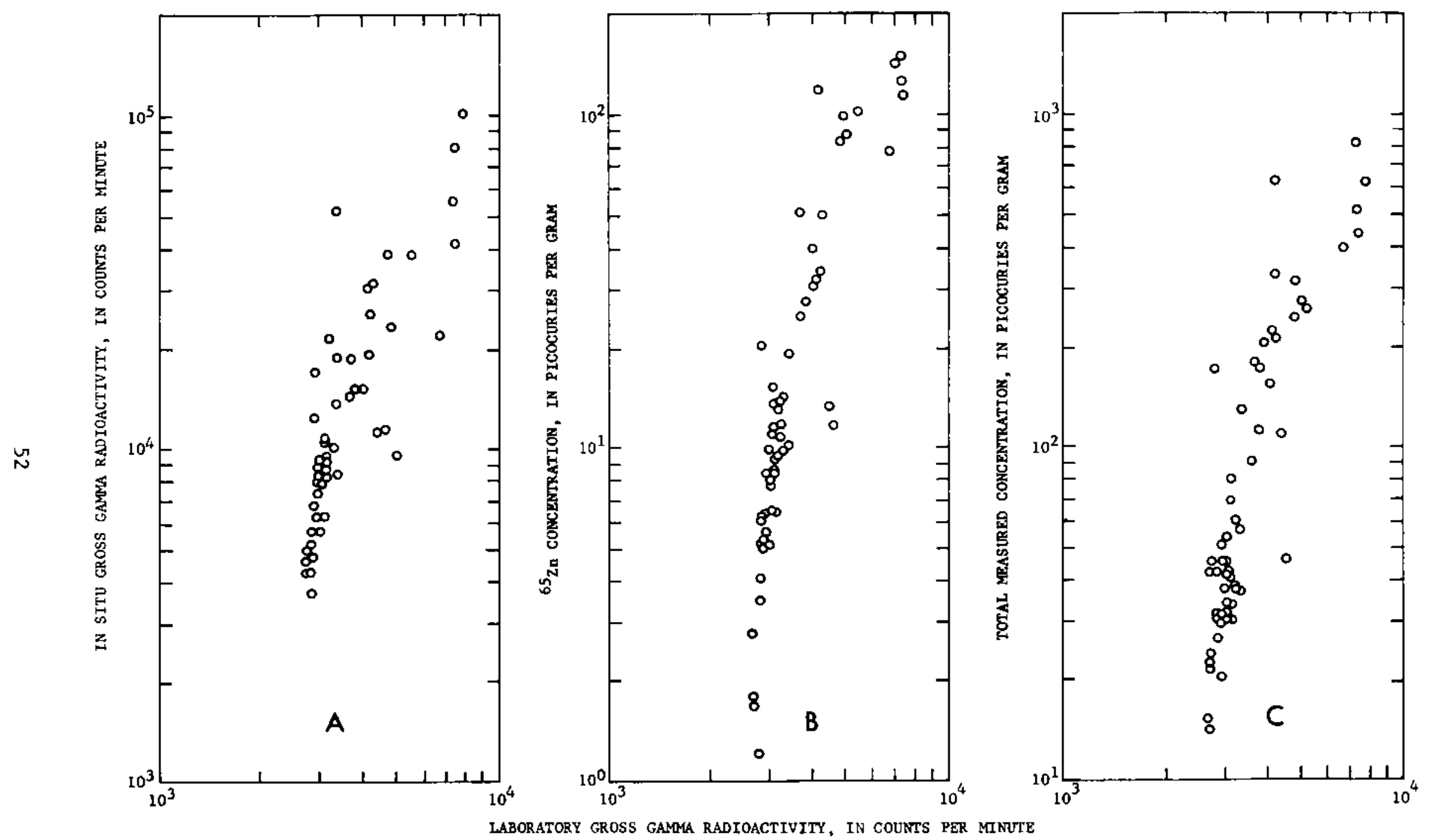

Figure 18.--Comparison of laboratory gross gamma count rates with in situ count rates and radionuclide concentrations. 


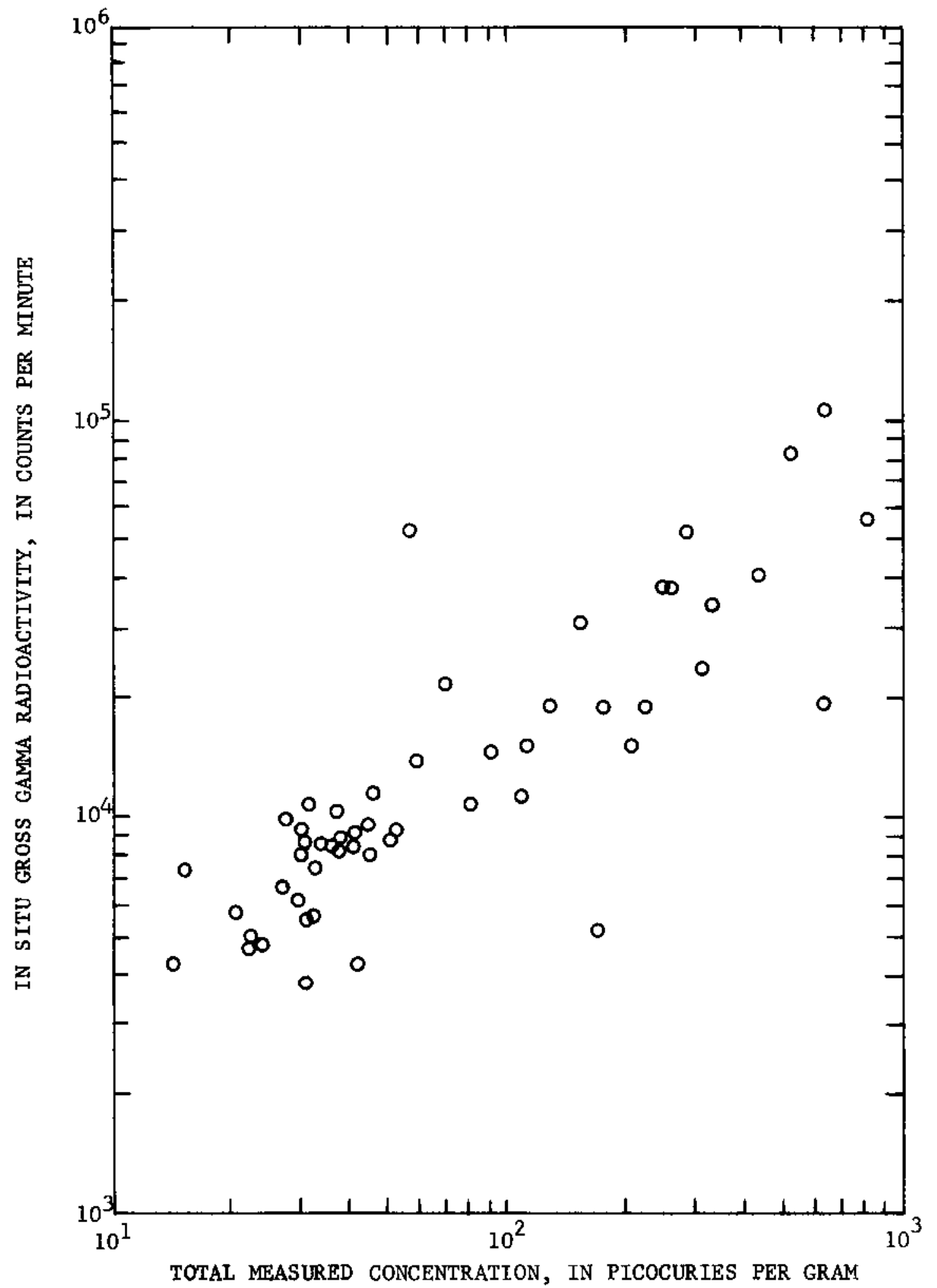

Figure 19.--Variation of in situ count rate with the total concerntraction of measured radionuclide in surficial sediment.

53 
due to variations in the composition of the radioactivity at various locations. However, the large deviations may be the result of collecting the sample in sediment of one activity level and counting, in situ, on sediment of a different activity level; experience has shown that in some locations large differences in radioactivity occur within short distances. Overall, it is apparent that in situ measurements can be used to estimate the concentration of an individual radionuclide, such as ${ }^{65} \mathrm{Zn}$, as well as the total concentration of radionuclides in surficial sediments.

In situ count rates are influenced most by radiation emanating from close to the detector; thus, although they indicate the concentration of radionuclides near the surface, they cannot be used directly to obtain the amount of radionuclides in the whole sediment column beneath the bed surface. This must be done by using average relationships.

In order to relate in situ count rates to an actual amount of radionuclides, count rates at core sites have been correlated with the amounts of radionuclides per unit area $1 /$ in the upper 8 inches of the bed (figs. 20 and 21). This particular correlation was used because calibrations in sand with several radionuclides (Sayre and Hubbell, 1965) indicated that with a uniformly distributed source of infinite depth, well over half of the counts result from radiation emanating from within about 8 inches of the surface. Also, in most cores the radionuclides extended at least 8 inches in depth and the radionuclide content often was defined by 1 -inch increments down to about the 8 -inch leve1.

Most scatter of the data in figures 20 and 21 appears to have resulted from measuring the in situ count rate at a location slightly offset

1/ The computation procedure used to determine the amount of radionuclides per unit area is described in appendix $V$. 


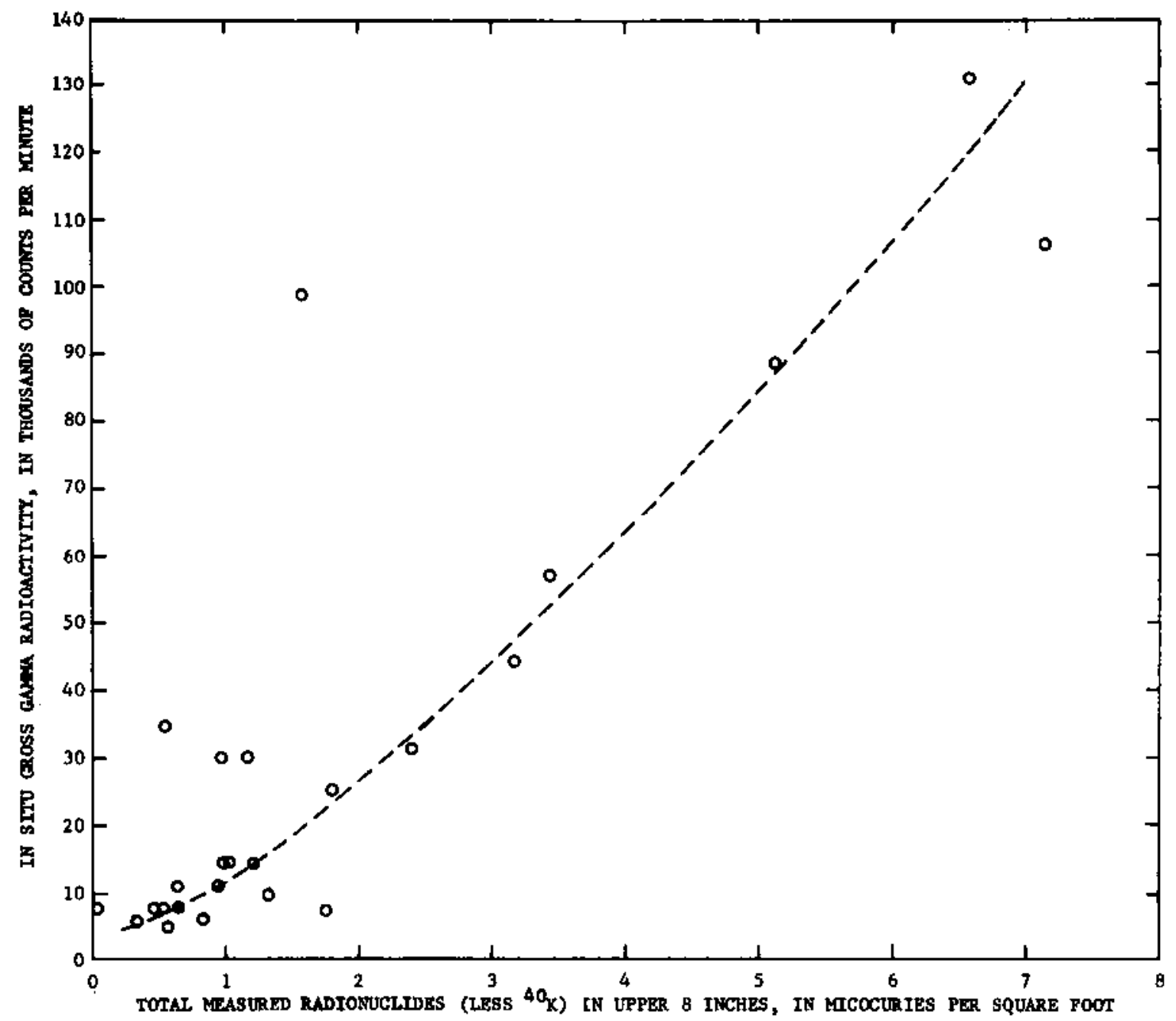

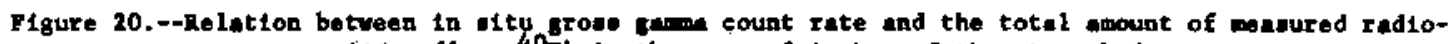
nucitdes (1eas $40 \mathrm{k}$ ) In the upper $B$ inches of the otrenabed. 


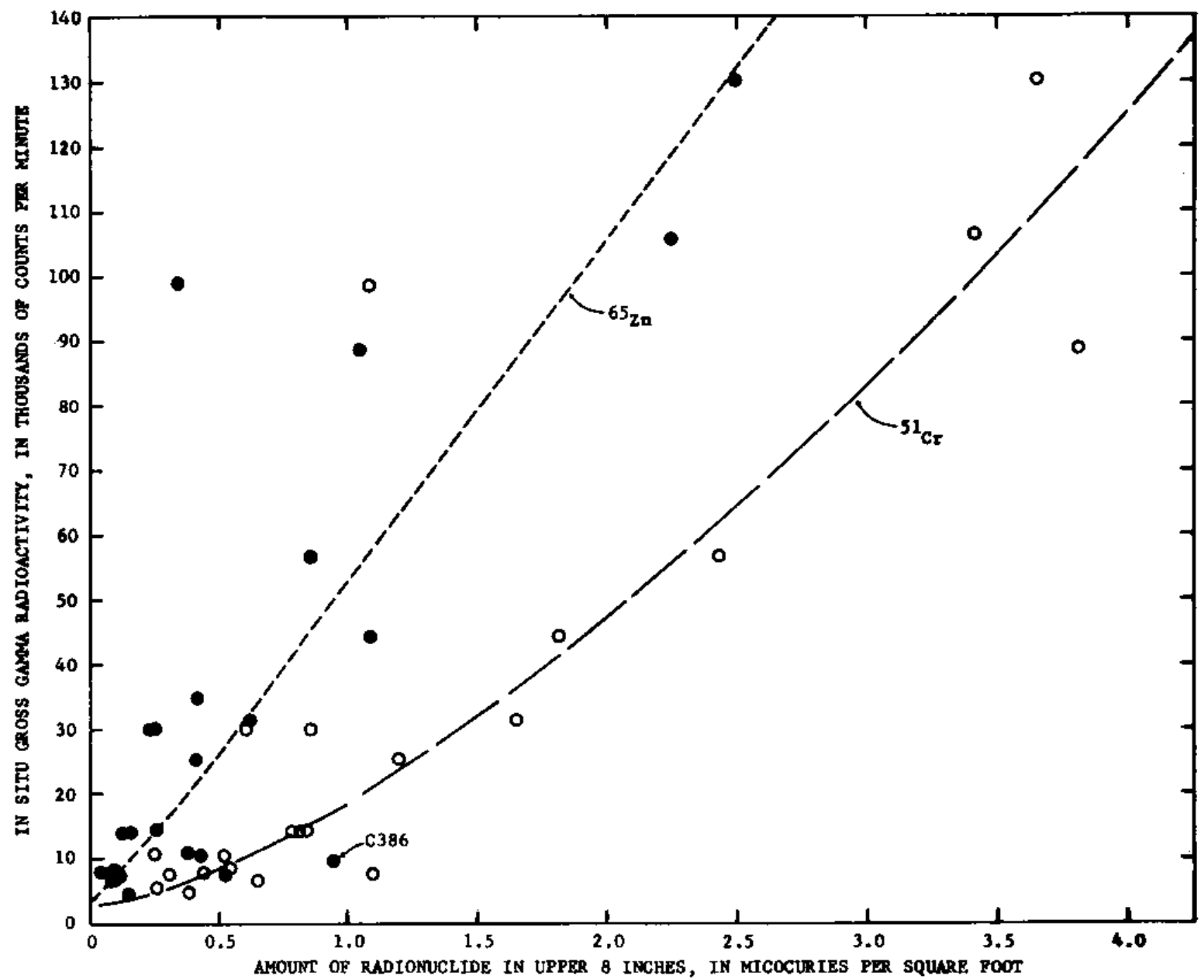

Figure 21.--Relations between in situ grass gaman count rateg and the anounts of 6520 (solid circles) and $5 \mathbf{l}_{\mathrm{Cr}}$ (open circles) in the upper 8 inches of the streambed. 
from the core site--the booms for handing the corer and the sleddetector unit were located at different positions on the boat so that identical positioning rarely was accomplished. This type of problem could have been particularly serious for the data from two cores that are farthest removed from the general trend of the points. For one other core (C386; fig. 21), which deviates substantially from other points with similar count rates, radionuclide concentrations (app. IV) for one segment (c386-3-1) appear to be in error by an order of magnitude. The dashed curves in these figures were defined from average values for selected ranges of in situ count rates (data that deviated greatly from the majority of points were excluded from the averages).

A histogram that depicts the distribution of all in situ count rates obtained during the survey is shown in figure 22 . The distribution is markedly asymmetrical with a predominance of count rates at 2 or 3 times the general background leve1, which is estimated to be 2,500 cpm (counts per minute), and with a scattering of count rates up to 70 times greater than the background level. Assuming that the distribution of data points in the estuary is reasonably representative, in situ count rates indicate that about 60 percent of the estuary bed has gross-gamma levels less than $10,000 \mathrm{cpm}$, about 19 percent has leve1s ranging from 10,000 to $20,000 \mathrm{cpm}$, and the remaining 21 percent has levels between 20,000 and $142,000 \mathrm{cpm}$.

Measurement locations and measured levels of gross-gamma radioactivity in each of the 14 cross sections are shown in figures 7 to 13 . Inspection of these data indicates that the level of activity varies markedly within cross sections. The general impression obtained from studying these figures is that low levels are associated with the channels; 


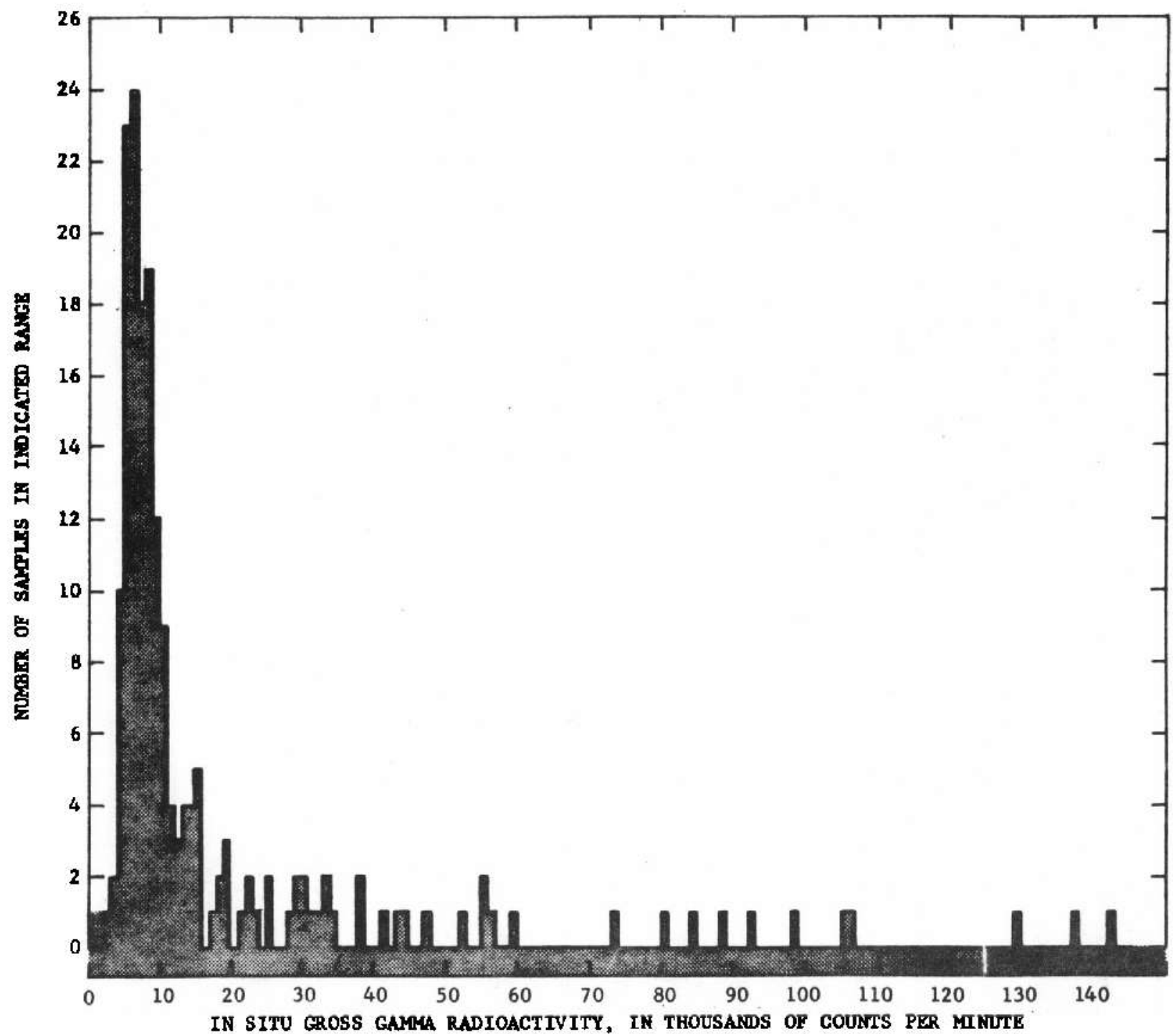

Figure 22.--Hiatogram of frequeacy distribution of in oitu count rates at eatuary crose cection. 
whereas, the activity level varies over a fairly wide range on the slopes and on the flats.

A summary of cross-sectional and longitudinal variations in grossgamma radioactivity is shown in table 5. The within-cross-section groups for this summary are the channe1s, slopes, and flats used to group surficial sediment texture data (table 2); cross sections and fluvial-transition-marine divisions are the longitudinal groups. The sumary (table 5) tends to substantiate the impressions mentioned above as well as to indicate possible longitudinal trends. In 8 out of 12 cross sections where a comparison can be made, average gross-gamma levels in channels are lower than or equal to levels on slopes and flats; in the latter two classes, the data suggest that flats tend to have higher levels than do slopes. In analyzing the data for longitudinal trends, comparisons among individual cross sections are probably not highly informative, chiefly because of insufficient data. When cross sections are combined into fluvial, marine, and transition divisions, it appears that gross-gamma radioactivity levels generally decrease toward the estuary mouth, although not uniformly for all geomorphic classes.

\section{Radionuclides in Surficial Sediment}

Information on individual gamma-emitting radionuclides associated with surficial sediments was obtained by analyzing selected samples from each cross section. In general, the selection of samples was based on the variation in "uncorrected" in situ count rates in a cross section and on rough qualitative appraisals of the physical characteristics of all cross-section samples. The attempt was to provide samples that would define the range in radioactivity and that as a composite would be representative of the sediment and radioactivity of a11 the samples in 
Table 5.--Average in situ gross gamma radioactivity at sample sites within each geomorphic class in each cross section

[Number of samples in average is shown in parenthesis]

\begin{tabular}{|c|c|c|c|c|c|}
\hline \multirow{2}{*}{$\begin{array}{l}\text { Longitudinal } \\
\text { division }\end{array}$} & \multirow{2}{*}{$\begin{array}{l}\text { Cross section } \\
\text { river mile } \\
\end{array}$} & In situ & gross gamms & \multicolumn{2}{|c|}{ radioactivity, in cpm } \\
\hline & & Channe 1s & Slopes & Flats & All classes \\
\hline \multirow{10}{*}{ Fluvial } & 64 & $9,600(2)$ & $31,000(5)$ & $-----(0)$ & $25,000(7)$ \\
\hline & 59 & $7,200(6)$ & $6,400 \quad(2)$ & $22,000(6)$ & $14,000(14)$ \\
\hline & 54 & $7,600(3)$ & $28,000(4)$ & $12,000 \quad(1)$ & $18,000(8)$ \\
\hline & 50 & $6,500(4)$ & $12,000(5)$ & $8,600(1)$ & $9,200(10)$ \\
\hline & 47 & $7,200(4)$ & $7,200(4)$ & $20,000(2)$ & $10,000(10)$ \\
\hline & 42 & $7,300(5)$ & $20,000(4)$ & $85,000 \quad(3)$ & $31,000(12)$ \\
\hline & 38 & $7,000(4)$ & $10,000(5)$ & 14,000 & $10,000(12)$ \\
\hline & 31 & $22,000(5)$ & $11,000(2)$ & $19,000(2)$ & $19,000(9)$ \\
\hline & 27 & $5,800(3)$ & $39,000(9)$ & $16,000 \quad(3)$ & $28,000(15)$ \\
\hline & $27-64$ & $9,100(36)$ & $22,000(40)$ & $26,000(21)$ & $18,000(97)$ \\
\hline \multirow{4}{*}{ Transition } & 23 & $10,000(5)$ & $17,000(8)$ & $23,000(4)$ & $16,000(17)$ \\
\hline & 18 & $15,000(5)$ & $7,000(4)$ & 8,400 (3) & $11,000(12)$ \\
\hline & 14 & $15,000(4)$ & $17,000(6)$ & $7,600 \quad(3)$ & $14,000(13)$ \\
\hline & $14-23$ & $13,000(14)$ & $15,000(18)$ & $14,000(10)$ & $14,000(42)$ \\
\hline \multirow{3}{*}{ Marine } & 6 & $9,300(5)$ & $11,000 \quad(3)$ & $16,000(8)$ & $13,000(16)$ \\
\hline & 2 & $5,000(1)$ & $5,500 \quad(2)$ & $\cdots(0)$ & $5,300(3)$ \\
\hline & $2-6$ & $7,800(6)$ & $8,900(5)$ & $16,000(8)$ & $12,000(19)$ \\
\hline A11 & $2-64$ & $9,800(56)$ & $19,000(63)$ & $21,000(39)$ & $16,000(158)$ \\
\hline
\end{tabular}


the cross section. That such early and empirical assessments were only moderately successful, is indicated by comparing the averages of selected size statistics and of in situ count rates for all samples in the cross section with the averages for the samples selected for radionuclide analysis (table 6). Overall, the samples selected for radionuclide analysis (table 6) were finer grained and had higher in situ count rates than the whole group of samples from the cross section. As a result, radionuclide data suffer not only because the overall sampling density was low, but also because the average of individual concentrations may not be directly representative of the concentration in the entire cross section.

In the radionuclide analyses, which were performed by the BattelleNorthwest Radiochemical Laboratory, the concentrations of eight gammaemitting nuclides were determined. The radionuclides include the five major activation products from the Hanford facilities, ${ }^{46} \mathrm{Sc},{ }^{51} \mathrm{Cr},{ }^{54} \mathrm{Mn}$, ${ }^{60} \mathrm{Co}$, and ${ }^{65} \mathrm{Zn}$; two abundant fallout radionuclides, ${ }^{95} \mathrm{Zr}-{ }^{95} \mathrm{Nb}$ and ${ }^{106} \mathrm{Ru}$; and the naturally occurring radionuclide, ${ }^{40} \mathrm{~K}$. These radionuclides make up the bulk of the radioactivity in the estuary; however, inasmuch as minor amounts of other radionuclides are present, henceforth in this report the term "measured radionuclides" is used to designate the eight gamma-emitting radionuclides quantified by the analyses.

The concentrations of individual radionuclides and selected computed totals and ratios for surficial sediment samples are shown in appendix III. The concentrations of the individual radionuclides are conversions to picocuries $2 /$ per gram (pc/g) of data originally presented in disintegrations per minute per gram $(\mathrm{d} / \mathrm{m} / \mathrm{g})$. The original data were reported to, and are believed to be accurate to $0.1 \mathrm{~d} / \mathrm{m} / \mathrm{g}$ for all concentrations

2/ 1 picocurie is equivalent to $10^{-12}$ curie. 
Table 6.--Comparioon of average vatues of aeveral size statiotica and in eitu grose gaman count raten for different sumple groups at each ewtury cross eection

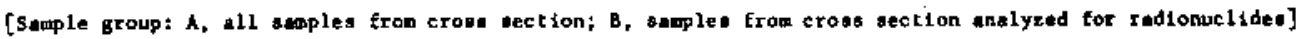

\begin{tabular}{|c|c|c|c|c|c|c|c|}
\hline \multirow{2}{*}{$\begin{array}{l}\text { Longi tudinal } \\
\text { diviaion }\end{array}$} & \multirow{2}{*}{$\begin{array}{l}\text { Croat aection } \\
\text { river mile }\end{array}$} & \multirow{2}{*}{$\begin{array}{l}\text { Sample } \\
\text { group }\end{array}$} & \multirow{2}{*}{$\begin{array}{l}\text { Number of } \\
\text { aquples in } \\
\text { group }\end{array}$} & \multicolumn{3}{|c|}{ Size otat1stics } & \multirow{2}{*}{ 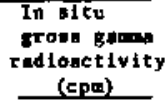 } \\
\hline & & & & $\mathrm{M}_{4}$ & $\sigma_{1}$ & $\alpha_{14}$ & \\
\hline \multirow{10}{*}{ Fluvigl } & 64 & A & $\begin{array}{l}7 \\
2\end{array}$ & $\begin{array}{l}2.09 \\
1.38\end{array}$ & $\begin{array}{r}0.70 \\
.55\end{array}$ & $\begin{array}{r}-0.05 \\
-.19\end{array}$ & $\begin{array}{r}25,000 \\
B, 300\end{array}$ \\
\hline & 59 & A & $\begin{array}{r}14 \\
4\end{array}$ & $\begin{array}{l}2.18 \\
2.33\end{array}$ & $\begin{array}{r}1.15 \\
.78\end{array}$ & $\begin{array}{l}-.06 \\
=.05\end{array}$ & $\begin{array}{l}24,000 \\
17,000\end{array}$ \\
\hline & 54 & $\begin{array}{l}\mathbf{A} \\
\mathbf{B}\end{array}$ & $\begin{array}{l}8 \\
3\end{array}$ & $\begin{array}{l}2.64 \\
2.46\end{array}$ & $\begin{array}{l}.85 \\
.71\end{array}$ & $\begin{array}{l}.02 \\
.01\end{array}$ & $\begin{array}{l}18,000 \\
13,000\end{array}$ \\
\hline & 50 & A & $\begin{array}{r}10 \\
2\end{array}$ & $\begin{array}{l}1.55 \\
2.13\end{array}$ & $\begin{array}{l}.53 \\
.39\end{array}$ & $\begin{array}{l}-.01 \\
=.06\end{array}$ & $\begin{array}{l}9,200 \\
8,800\end{array}$ \\
\hline & 47 & $\begin{array}{l}\text { A } \\
\text { B }\end{array}$ & $\begin{array}{r}10 \\
4\end{array}$ & $\begin{array}{l}1.66 \\
2.05\end{array}$ & $\begin{array}{l}.46 \\
.45\end{array}$ & $\begin{array}{r}-.02 \\
.03\end{array}$ & $\begin{array}{l}10,000 \\
14,000\end{array}$ \\
\hline & 42 & $\hat{\text { B }}$ & $\begin{array}{r}14 \\
5\end{array}$ & $\begin{array}{l}2.71 \\
2.39\end{array}$ & $\begin{array}{r}.87 \\
.97\end{array}$ & $\begin{array}{r}.04 \\
-.01\end{array}$ & $\begin{array}{l}31,000 \\
20,000\end{array}$ \\
\hline & 38 & $\hat{\mathbf{A}}$ & $\begin{array}{r}12 \\
4\end{array}$ & $\begin{array}{l}2.13 \\
2.69\end{array}$ & $\begin{array}{l}.91 \\
.70\end{array}$ & .14 & $\begin{array}{l}10,000 \\
13,000\end{array}$ \\
\hline & 31 & $\begin{array}{l}\text { A } \\
\text { B }\end{array}$ & 9 & $\begin{array}{l}2.29 \\
2.12\end{array}$ & $\begin{array}{l}.68 \\
.84\end{array}$ & $\begin{array}{l}.03 \\
.01\end{array}$ & $\begin{array}{l}19,000 \\
28,000\end{array}$ \\
\hline & 27 & $\begin{array}{l}\text { A } \\
B\end{array}$ & $\begin{array}{r}15 \\
4\end{array}$ & $\begin{array}{l}2.84 \\
4.45\end{array}$ & $\begin{array}{r}.95 \\
1.53\end{array}$ & .04 & $\begin{array}{l}28,000 \\
42,000\end{array}$ \\
\hline & $27-64$ & A & $\begin{array}{l}99 \\
32\end{array}$ & $\begin{array}{l}2.27 \\
2.53\end{array}$ & $\begin{array}{l}.82 \\
.81\end{array}$ & $\begin{array}{l}.02 \\
.00\end{array}$ & $\begin{array}{l}18,000 \\
20,000\end{array}$ \\
\hline \multirow{4}{*}{ Trabeftion } & 23 & $\begin{array}{l}\text { A } \\
\text { B }\end{array}$ & $\begin{array}{r}17 \\
5\end{array}$ & $\begin{array}{l}2.64 \\
2.36\end{array}$ & $\begin{array}{l}.68 \\
.64\end{array}$ & $\begin{array}{r}.06 \\
-.10\end{array}$ & $\begin{array}{l}16,000 \\
16,000\end{array}$ \\
\hline & 18 & $\begin{array}{l}\text { A } \\
\mathrm{B}\end{array}$ & $\begin{array}{r}12 \\
4\end{array}$ & $\begin{array}{l}2.36 \\
2.74\end{array}$ & $\begin{array}{l}.79 \\
.90\end{array}$ & $\begin{array}{l}.03 \\
.07\end{array}$ & $\begin{array}{l}11,000 \\
16,000\end{array}$ \\
\hline & 14 & $\begin{array}{l}\text { A } \\
\text { B }\end{array}$ & $\begin{array}{r}13 \\
4\end{array}$ & $\begin{array}{l}2.62 \\
2.92\end{array}$ & $\begin{array}{r}.70 \\
1.02\end{array}$ & $\begin{array}{l}.07 \\
.04\end{array}$ & $\begin{array}{l}14,000 \\
15,000\end{array}$ \\
\hline & $14-23$ & A & $\begin{array}{l}42 \\
13\end{array}$ & $\begin{array}{l}2.55 \\
2.65\end{array}$ & $\begin{array}{l}.72 \\
.84\end{array}$ & $\begin{array}{r}.05 \\
-.01\end{array}$ & $\begin{array}{l}14,000 \\
16,000\end{array}$ \\
\hline \multirow{3}{*}{ Merine } & 6 & $\begin{array}{l}\hat{A} \\
\mathbf{B}\end{array}$ & $\begin{array}{r}16 \\
5\end{array}$ & $\begin{array}{l}3.16 \\
2.67\end{array}$ & $\begin{array}{r}1.03 \\
.66\end{array}$ & $\begin{array}{l}.22 \\
.14\end{array}$ & $\begin{array}{l}13,000 \\
18,000\end{array}$ \\
\hline & 2 & A & $\begin{array}{l}4 \\
3\end{array}$ & $\begin{array}{l}2.46 \\
2.01\end{array}$ & $\begin{array}{l}.67 \\
.28\end{array}$ & $\begin{array}{r}.14 \\
-.09\end{array}$ & $\begin{array}{l}5,300 \\
4,600\end{array}$ \\
\hline & $2-6$ & $\mathbf{A}$ & $\begin{array}{r}20 \\
8\end{array}$ & $\begin{array}{l}3.02 \\
2.42\end{array}$ & $\begin{array}{l}.96 \\
.52\end{array}$ & $\begin{array}{l}.20 \\
.06\end{array}$ & $\begin{array}{l}12,000 \\
14,000\end{array}$ \\
\hline A11 & $2-64$ & B & $\begin{array}{r}16 \overline{1} \\
53\end{array}$ & $\begin{array}{l}2.44 \\
2.54\end{array}$ & $\begin{array}{l}.81 \\
.78\end{array}$ & $\begin{array}{l}.05 \\
.01\end{array}$ & $\begin{array}{l}16,000 \\
16,000\end{array}$ \\
\hline
\end{tabular}


greater than $0.5 \mathrm{~d} / \mathrm{m} / \mathrm{g}$, except for ${ }^{5 l_{\mathrm{Cr}}}$ concentrations, which were reported to the nearest whole disintegration per minute per gram for concentrations greater than $5 \mathrm{~d} / \mathrm{m} / \mathrm{g}$. The computed picocurie values reflect the number of significant figures in the original disintegration-perminute-per-gram data except for ${ }^{51} \mathrm{Cr}$ which usually has one additional significant figure. Certain values have been denoted as "questionable" (app. III). In general, the assignment of these values to a questionable category was done by the analyst if anomalous concentration(s) of a radionuclide(s) appeared to be present. As a general and arbitrary rule, less-than values have been added into computed totals as if they were real values under the general assumption that their small magnitude would not affect seriously the results. Totals and ratios have not been computed if questionable or missing values were involved, nor have ratios been computed with questionable or less-than values.

Data on radionuclides in 10 surficial sediment samples that were collected on preliminary cruises during October 1964 are also shown in appendix III. Results from these samples (as wel1 as from some early cores) have not been utilized in this report except in figure 23 . (See equation 1, p. 77 , for definition of specific surface.) Data in this figure suggest that different correlations exist between variables from the 1964 data and similar variables from the 1965 survey. Information obtained since 1965 has indicated that the amount of radionuclides associated with surficial sediment varies seasonally, apparently in response to the changing hydrologic regime, and that it is diminishing with the reduction in the number of reactors in operation at Hanford. Very likely the generally lower levels of ${ }^{65} \mathrm{Zn}$ and ${ }^{51} \mathrm{Cr}$ in 1965 (fig. 23) reflect both the decrease in reactor operations between 1964 and 1965 and 


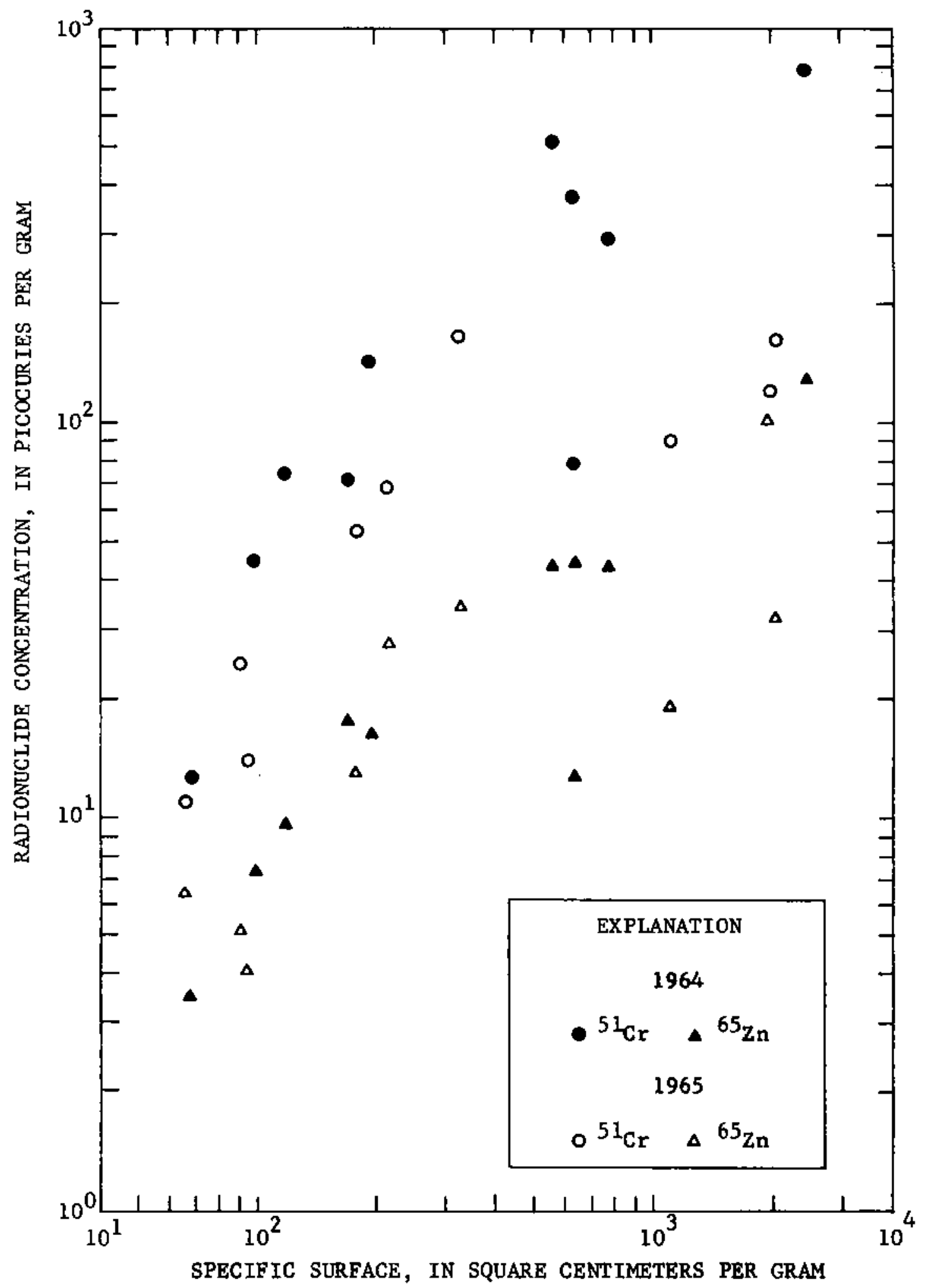

Figure 23.--Relations between $5 \mathrm{C} \mathrm{Cr}$ and $65 \mathrm{Zn}$ concentrations and specific surface of surficial sediment samples obtained between Columbia River miles 14 and 18 in October 1964 and June 1965. 
the tendency (ill defined) for levels in June to be somewhat lower than levels at other times throughout the year. As a result of these influences, the levels of radioactivity and the amounts of radionuclides reported herein can be presumed to vary somewhat and probably are higher than have existed after 1965.

Total concentrations of measured radionuclides and the proportions of the totals that are ${ }^{65} \mathrm{Zn}$ and ${ }^{51} \mathrm{Cr}$ are shown in figures 7 to 13 along with in situ count rates and particle-size statistics. As would be antlcipated from the discussion on the distribution of gross-gamna radioactivity, individual radionuclide concentrations appear to attain highest levels in samples from sites on slopes and flats adjacent to channels.

Individual radionuclide data are sumarized by cross section, geomorphic class, and fluvial-transition-marine longitudinal divisions in tables 7 and 8 . Inspection of these data indicates the following:

1. Average amounts of ${ }^{51} \mathrm{Cr},{ }^{65} \mathrm{Zr},{ }^{46} \mathrm{Sc}, 106 \mathrm{Ru},{ }^{54} \mathrm{Mn},{ }^{60} \mathrm{Co}$, and $95_{\mathrm{Zr}-}{ }^{95} \mathrm{Nb}$ are about $6.2,2.2,0.2,0.1,0.07,0.06$, and 0.05 times as abundant, respectively, in Columbia River estuary surficial sediments as ${ }^{40} \mathrm{~K}$, which is fairly constant and averages about $14 \mathrm{pc} / \mathrm{g}$ in inorganic estuary sediments.

2. Mean radionuclide ratios appear to indicate significant changes in relative amounts of some radionuclides along the estuary; for example, ${ }^{5 \mathrm{I}} \mathrm{Cr}$ appears to increase relative to ${ }^{65} \mathrm{Zn}$ toward the estuary mouth.

3. Large differences, reflecting the selection of samples for analysis as well as probable extreme natural differences, exist between the average radionuclide concentrations of the various cross sections. 


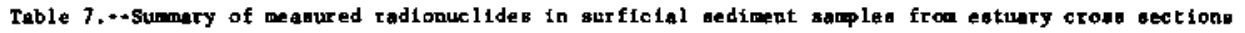

[Statiotic: $\bar{x}$ and a ere nean and atandard deviation of anplea, reapectively; ratio volued coaputed by ualng only individual ration listed in Appendix III]

\begin{tabular}{|c|c|c|c|c|c|c|c|c|c|c|c|c|c|c|}
\hline \multirow{2}{*}{$\begin{array}{l}\text { Langit tudinal } \\
\text { divioion }\end{array}$} & \multirow[b]{2}{*}{$\begin{array}{l}\text { Crons aection } \\
\text { river mile }\end{array}$} & \multirow{2}{*}{$\begin{array}{l}\text { Number } \\
\text { of } \\
\text { gamples }\end{array}$} & \multirow[b]{2}{*}{ statiotic } & \multicolumn{8}{|c|}{ Radionuclide copcentration, fo picocuries per gram } & \multicolumn{3}{|c|}{ Retion } \\
\hline & & & & Co-60 & $2 n-65$ & Mn-54 & $\mathrm{Se}-46$ & $c_{r}-51$ & $84-106$ & $2 \mathrm{rkb}-95$ & $\overline{k=40}$ & $\frac{2 \pi-65}{60-60}$ & $\frac{5 s-46}{2 n-65}$ & $\frac{\mathrm{Cr}+51}{2 \mathrm{n}-65}$ \\
\hline \multirow{10}{*}{ Fluvial } & 64 & 4 & $\overline{\mathbf{x}}$ & 0.7 & 28.0 & 0.7 & 2,1 & $1 / 59.2$ & 1.7 & 0.3 & 12.2 & 50 & 0.05 & 1.338 \\
\hline & 59 & 5 & $\bar{x}$ & 1.5 & 36.0 & .8 & 3.1 & 61.0 & .9 & .7 & 12.8 & 30 & .073 & 1.77 \\
\hline & 54 & $\mathbf{3}$ & $\overline{\mathbf{x}}$ & .6 & 32.3 & 1.0 & $1 / 2$ & 101.0 & 1.2 & 1.0 & 12.8 & 50 & .03 & 1.97 \\
\hline & 50 & 3 & $\overline{\mathbf{x}}$ & .3 & 11.2 & .3 & .2 & 11.4 & .3 & .2 & 13,3 & 40 & $3 / .02$ & 1.58 \\
\hline & 47 & 5 & $\overline{\mathbf{x}}$ & .3 & 15.0 & .5 & .8 & $1 / 33,9$ & .4 & .3 & 12.0 & 40 & .05 & 2.11 \\
\hline & 42 & 5 & $\overline{\mathbf{x}}$ & .8 & 30.9 & 1.2 & 3.4 & 110.5 & 1.4 & .7 & 12.3 & 40 & .06 & 2.7 \\
\hline & 38 & 4 & $\hat{\mathbf{x}}$ & 1.1 & 32.5 & .9 & 1.9 & 56,9 & 1.2 & .8 & 14.9 & $2 / 26$ & .05 & 1.79 \\
\hline & 31 & 4 & $\overline{\mathbf{x}}$ & .9 & 37.8 & 1.3 & 3.8 & 106.9 & 1.7 & .7 & 12.9 & 50 & .07 & 1.84 \\
\hline & 27 & 4 & $\overline{\mathbf{x}}$ & 2.1 & 66.0 & 2.2 & 6.5 & 170.7 & 4.2 & 1.6 & 18.6 & 34 & .11 & 2.37 \\
\hline & $27-64$ & 37 & {$\left[\begin{array}{l}\tilde{\mathbf{x}} \\
\dot{\theta}\end{array}\right]$} & $\begin{array}{r}.9 \\
1.4\end{array}$ & $\begin{array}{l}32.3 \\
41.1\end{array}$ & $\begin{array}{l}1.0 \\
1.3\end{array}$ & $\begin{array}{r}1 / 2.8 \\
5.6\end{array}$ & $\begin{array}{l}1 / 61.9 \\
125.5\end{array}$ & $\begin{array}{l}1.4 \\
1.9\end{array}$ & .7 & $\begin{array}{r}13.5 \\
4.4\end{array}$ & $\begin{array}{l}40 \\
14\end{array}$ & .06 & $\begin{array}{c}2.01 \\
.9\end{array}$ \\
\hline \multirow{4}{*}{$\begin{array}{l}\text { Transition } \\
\text {. }\end{array}$} & 23 & 5 & 8 & .8 & 33.9 & 1.3 & 4.0 & 133.9 & 1.6 & .8 & 13.4 & 30 & $2 / .129$ & 2.98 \\
\hline & 18 & 4 & $\pi$ & 1.0 & 35.0 & 1.3 & . 2.9 & 53.4 & 1.3 & .8 & 13.2 & 30 & .07 & 2.2 \\
\hline & 14 & 5 & $\star$ & .9 & 20.7 & .8 & $1 / 2.2$ & 97.0 & 1.4 & .5 & 14.8 & 27 & .12 & 4.62 \\
\hline & $14-23$ & 14 & {$\left[\begin{array}{l}\overline{\mathbf{x}} \\
\mathrm{B}\end{array}\right.$} & $\begin{array}{l}.9 \\
.9\end{array}$ & $\begin{array}{l}29.5 \\
42.7\end{array}$ & $\begin{array}{l}1.1 \\
1.6\end{array}$ & $\begin{array}{r}1 / 3.1 \\
5.3\end{array}$ & $\begin{array}{r}97.7 \\
156.5\end{array}$ & $\begin{array}{l}1,4 \\
1,6\end{array}$ & .7 & $\begin{array}{r}13.9 \\
4.1\end{array}$ & $\begin{array}{l}30 \\
14\end{array}$ & $\begin{array}{l}.10 \\
.05\end{array}$ & $\begin{array}{l}3.3 \\
1.3\end{array}$ \\
\hline \multirow{3}{*}{ Marine } & 6 & 5 & $*$ & .8 & 22.9 & .6 & 2.3 & 111.2 & 2.0 & .5 & 14.2 & 30 & .12 & 5.61 \\
\hline & 2 & 3 & $\pi$ & .2 & 1.6 & .2 & .2 & 3.8 & .2 & .2 & 12.1 & $-\ldots$ & \multicolumn{2}{|c|}{$\ldots \ldots / 3.8$} \\
\hline & $2-6$ & 8 & {$\left[\begin{array}{l}\dot{x} \\
1\end{array}\right.$} & .6 & $\begin{array}{l}14.9 \\
19.1\end{array}$ & $\begin{array}{l}.5 \\
.4\end{array}$ & $\begin{array}{l}1.5 \\
1.7\end{array}$ & $\begin{array}{l}71.0 \\
88.5\end{array}$ & $\begin{array}{l}1.3 \\
1.6\end{array}$ & $\begin{array}{l}.4 \\
.3\end{array}$ & $\begin{array}{r}13.4 \\
2.4\end{array}$ & $\begin{array}{r}30 \\
6\end{array}$ & $\begin{array}{l}.12 \\
.03\end{array}$ & $\begin{array}{l}5.3 \\
1.4\end{array}$ \\
\hline All & $2-64$ & 59 & {$\left[\begin{array}{l}\bar{x} \\
0\end{array}\right.$} & $\begin{array}{r}.8 \\
1.2\end{array}$ & $\begin{array}{l}29.3 \\
39.2\end{array}$ & $\begin{array}{l}1.0 \\
1.3\end{array}$ & $\begin{array}{r}1 / 2.7 \\
5.1\end{array}$ & $\begin{array}{l}1_{64.3} \\
127.7\end{array}$ & $\begin{array}{l}1.4 \\
1.8\end{array}$ & .7 & $\begin{array}{r}13.6 \\
4.0\end{array}$ & $\begin{array}{l}34 \\
15.4\end{array}$ & $\begin{array}{r}.076 \\
+.044\end{array}$ & $\begin{array}{l}2.78 \\
1.59\end{array}$ \\
\hline
\end{tabular}

J Include: leve-then value but excludes questionable values.

2 0 ne anmile only. 
Table 8.--Variation of measured radionuclides in surficial sediment samples with geomorphic class and longitudinal division

[Statistic: $\bar{x}$ and $s$ are mean and standard deviation of samples, respectively]

\begin{tabular}{|c|c|c|c|c|c|c|c|c|c|c|c|}
\hline \multirow{2}{*}{$\begin{array}{l}\text { Longitudinal } \\
\text { division }\end{array}$} & \multirow{2}{*}{$\begin{array}{l}\text { Geomorphic } \\
\text { class }\end{array}$} & \multirow{2}{*}{$\begin{array}{l}\text { Number } \\
\text { of } \\
\text { samples }\end{array}$} & \multirow[b]{2}{*}{ Statistic } & \multicolumn{8}{|c|}{ Radionuclide concentration, in picocuries per gram } \\
\hline & & & & $\mathrm{Co}-60$ & $\mathrm{Zn}-65$ & $\mathrm{Mn}-54$ & Sc-46 & $\mathrm{Cr}-5 \mathrm{I}$ & Ru-106 & $\mathrm{ZrNb}-95$ & $K-40$ \\
\hline \multirow{3}{*}{ Fluvial } & Channels & 17 & $\begin{array}{c}\ddot{x} \\
s\end{array}$ & $\begin{array}{r}0.4 \\
.6\end{array}$ & $\begin{array}{l}15.2 \\
25.4\end{array}$ & $\begin{array}{r}0.5 \\
.9\end{array}$ & $\begin{array}{l}1.1 \\
3.2\end{array}$ & $\begin{array}{l}32.9 \\
84.5\end{array}$ & $\begin{array}{l}0.7 \\
1.3\end{array}$ & $\begin{array}{r}0.3 \\
.5\end{array}$ & $\begin{array}{r}12.1 \\
2.7\end{array}$ \\
\hline & Slopes & 13 & $\begin{array}{l}\bar{x} \\
s\end{array}$ & $\begin{array}{l}1.2 \\
1.4\end{array}$ & $\begin{array}{l}40.6 \\
41.2\end{array}$ & $\begin{array}{l}1.3 \\
1.4\end{array}$ & $\begin{array}{l}3.5 \\
6.8\end{array}$ & $\begin{array}{l}106.4 \\
133.6\end{array}$ & $\begin{array}{l}1.9 \\
2.1\end{array}$ & $\begin{array}{l}1.0 \\
1.1\end{array}$ & $\begin{array}{r}14.7 \\
5.8\end{array}$ \\
\hline & Flats & 7 & $\begin{array}{c}\bar{x} \\
s\end{array}$ & $\begin{array}{l}1.8 \\
2.2\end{array}$ & $\begin{array}{l}58.6 \\
56.9\end{array}$ & $\begin{array}{l}1.7 \\
1.7\end{array}$ & $\begin{array}{l}5.9 \\
6.7\end{array}$ & $\begin{array}{l}168.5 \\
165.6\end{array}$ & $\begin{array}{l}2.3 \\
2.7\end{array}$ & $\begin{array}{l}1.1 \\
1.1\end{array}$ & $\begin{array}{r}14.4 \\
4.5\end{array}$ \\
\hline \multirow{3}{*}{ Transition } & Channels & 7 & $\begin{array}{c}\bar{x} \\
s\end{array}$ & $\begin{array}{l}1.0 \\
1.0\end{array}$ & $\begin{array}{l}25.4 \\
35.7\end{array}$ & $\begin{array}{r}.9 \\
1.3\end{array}$ & $\begin{array}{l}2.7 \\
3.7\end{array}$ & $\begin{array}{l}61.5 \\
61.9\end{array}$ & $\begin{array}{l}1.6 \\
1.2\end{array}$ & $\begin{array}{l}.7 \\
.9\end{array}$ & $\begin{array}{r}13.3 \\
4.1\end{array}$ \\
\hline & Slopes & 6 & $\begin{array}{c}\bar{x} \\
s\end{array}$ & $\begin{array}{l}.8 \\
.9\end{array}$ & $\begin{array}{l}34.8 \\
56.1\end{array}$ & $\begin{array}{l}1.4 \\
2.2\end{array}$ & $\begin{array}{l}4.1 \\
7.5\end{array}$ & $\begin{array}{l}144.8 \\
233.3\end{array}$ & $\begin{array}{l}1.4 \\
2.2\end{array}$ & $\begin{array}{r}.7 \\
1.1\end{array}$ & $\begin{array}{r}14.6 \\
4.9\end{array}$ \\
\hline & Flats & 1 & - & .6 & 27.1 & 1.0 & 1.4 & 68.5 & .6 & .2 & 13.6 \\
\hline \multirow{3}{*}{ Marine } & Channels & 4 & $\begin{array}{c}\overline{\mathrm{x}} \\
\mathrm{s}\end{array}$ & $\begin{array}{r}.2 \\
.1\end{array}$ & $\begin{array}{l}3.8 \\
2.4\end{array}$ & $\begin{array}{l}.4 \\
.1\end{array}$ & $\begin{array}{l}.5 \\
.4\end{array}$ & $\begin{array}{l}21.8 \\
21.3\end{array}$ & $\begin{array}{l}.3 \\
.2\end{array}$ & $0^{.2}$ & $\begin{array}{r}12.7 \\
.6\end{array}$ \\
\hline & Slopes & 2 & $\begin{array}{c}\bar{x} \\
s\end{array}$ & $\begin{array}{r}.4 \\
.3\end{array}$ & $\begin{array}{l}7.4 \\
8.7\end{array}$ & $\begin{array}{l}.8 \\
.8\end{array}$ & $\begin{array}{l}1.0 \\
1.1\end{array}$ & $\begin{array}{l}41.3 \\
55.1\end{array}$ & $\begin{array}{l}.8 \\
.8\end{array}$ & $0^{.2}$ & $\begin{array}{r}11.1 \\
.8\end{array}$ \\
\hline & Flats & 2 & $\begin{array}{c}\bar{x} \\
s\end{array}$ & $\begin{array}{r}1.4 \\
.3\end{array}$ & $\begin{array}{r}44.8 \\
7.4\end{array}$ & $\begin{array}{r}.4 \\
.1\end{array}$ & $\begin{array}{r}4.1 \\
.7\end{array}$ & $\begin{array}{r}199.0 \\
79.2\end{array}$ & $\begin{array}{r}3.8 \\
.4\end{array}$ & $\begin{array}{l}.9 \\
.1\end{array}$ & $\begin{array}{r}17.0 \\
.3\end{array}$ \\
\hline
\end{tabular}


4. Even when samples from cross sections are combined and only fluvial, transition, and marine divisions are recognized, the standard deviations of radionuclide concentrations typically are greater than the means and generally are so large as to preclude positive conclusions relative to changes in individual radionuclide concentrations along the estuary. The apparent decrease in average concentrations of some radionuclides along the estuary, although such a decrease would not be unexpected, may be entirely fortuitous.

5. When samples from the fluvial, transition, and marine divisions are divided and assigned to previously described geomorphic classes (table 8), standard deviations of radionuclide concentrations appear to be reduced somewhat although differences among classes within a division and among classes between divisions are still not highly significant.

Data in appendix III indicate that some sample localities exhibit extreme local variations in radionuclide content whereas other localities are fairly homogeneous. Samples at location G344 (p1. 1) 111ustrate the one extreme; that is, over a twofold difference in radionuclide concentrations between duplicate samples. Samples from location G214 show the other extreme. Unpublished data from 5 to 20 replicate samples (collected after the 1965 data reported herein) from four locations in the Astoria area have indicated that with some radionuclides standard deviations are as large as 50 percent of mean concentrations. On the basis of this data it appears that rather large deviations in radionuclide concentrations may be the rule rather than the exception. 
Several possible reasons exist for the rather large observed variances in radionuclide concentrations in duplicate samples, and three possible reasons $c$ an be illustrated with the available data. Probably the major influence, which is discussed in more detail in a subsequent section, is the physical composition of the sample. If particle size is used as in indicator of composition, size data (app. I) for the duplicate samples from location G344 indicate a pronounced difference in composition between the two samples with the coarser sample containing generally less radionuclides. In addition, at the G344 sample site, as well as at other sample sites in the marine and transition divisions of the estuary, variable amounts of pebble-to-cobble-size, blue-black, rounded, clay balls occur. Radionuclide analysis (G344-B-65) of the clay balls from the 6344 sample site shows that they contain less radionuclides than their fine texture suggests should be present. Although the exact origin of the clay balls can only be inferred at the present time, their characteristics and known distribution suggest that they represent erosion products from an ephemeral clay cap found principally in areas influenced by intrusion of saline waters.

Organic-matter content is another factor that may be important in influencing radionuclide concentrations. Sample G254-A-65 (app. IIr) consists exclusively of wood fibers and chips from a sample site near where these materials are loaded on barges for transport to markets. The radionuclide data for this sample and for sample G254--65, which is both inorganic and organic material from the same sample location as G254-A-65, indicate that the organic fraction can be an important radionuclide-bearing component. Relatively low concentrations (app. III) of naturally occurring $40_{\mathrm{K}}$ generally are an indication that large amounts of organic material are present. 


\section{Radionuclides in Cores}

Limitations on the number of core segments that could be analyzed for individual radionuclides necessitated the selection of segments for analysis. The selection procedure began with an empirical judgment on the possible depth to which significant radioactivity might extend in each core. Then, segments that illustrated the stratigraphy and stratigraphic changes within each core were designated for possible radionuclide analysis. The final selection of segments, however, was necessarily in the hands of the analyst who attempted to portray as completely as possible the stratigraphic distribution of radionuclides in each core. For most cores, this resulted in an analysis of an initial set of core segments followed by an analysis of a second set when preliminary results from the initial set indicated stratigraphic gaps in radionuc lide data. Concentrations of ${ }^{5 l_{\mathrm{Cr}}}$ often were not determined in the segments from the second set due to its decay (half life equals 27.8 days).

Results from radionuclide analyses of 258 segments from the 25 cores collected during the survey and 29 segments from 2 cores (C3 and C6) collected earlier in the year are shown in appendix IV. As with data for the surficial sediment samples, less-than values have been added into the totals but not used in ratio computations, and no totals were computed for segments with missing or questionable data. Additional data pertaining to the geomorphic position, texture, and stratigraphy at each core site are included in table 3 and figure 17.

Stratigraphic distributions of ${ }^{65} \mathrm{Zn}$ and ${ }^{51_{\mathrm{Cr}}} \mathrm{Concentrations}$ and of the total concentration of measured radionuclides (excluding $40_{\mathrm{K}}$ ) are shown in figure 24 for five cores, and summary data for all cores are 


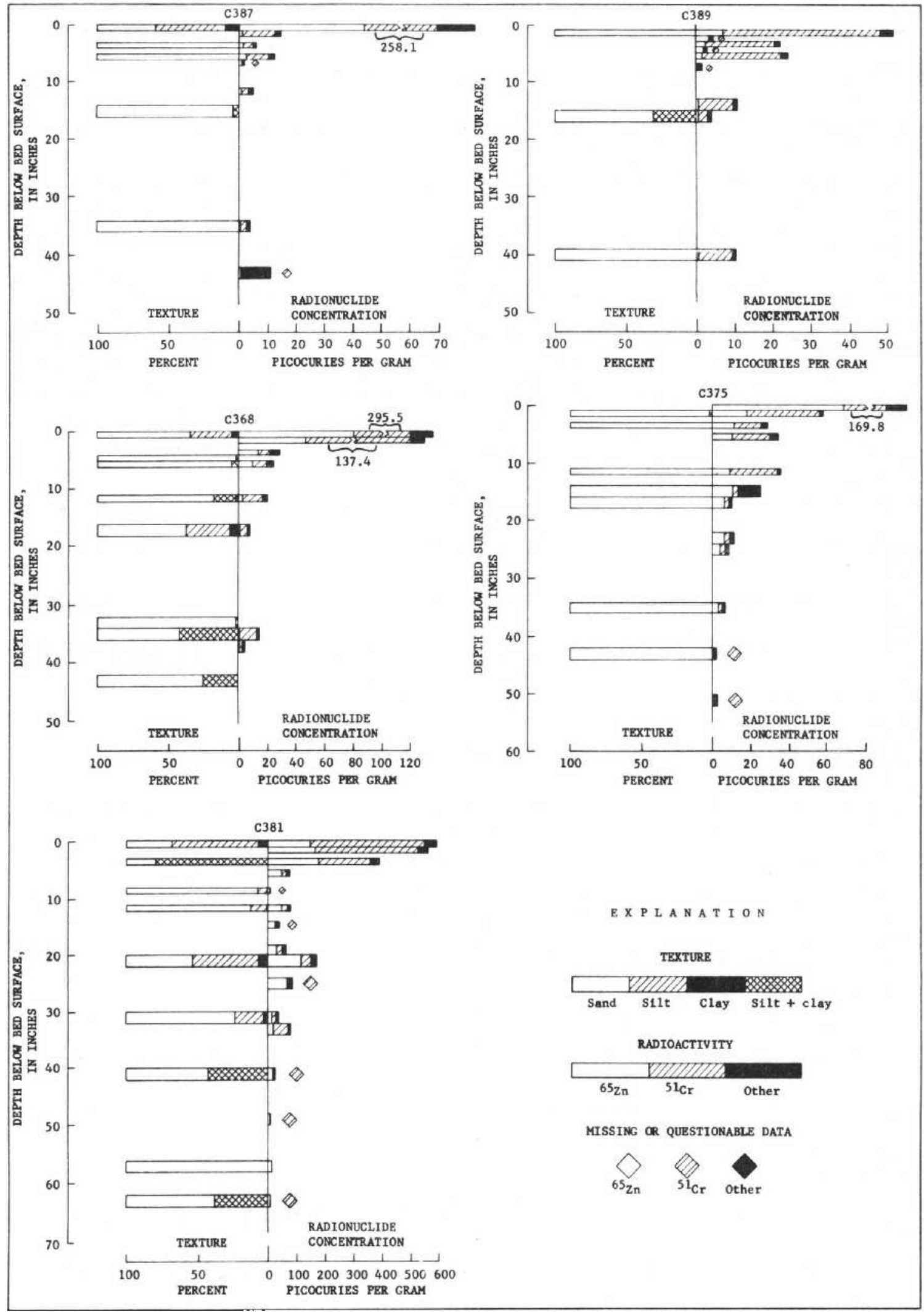

Figure 24.--Stratigraphic distribution of radionuclide concentrations and sediment texture in cores from the Columbia River estuary. The length of the concentration bars denote the total concentration of measured radionuclides less $40_{K}$. 
contained in table 9 . (See p. 54 and app. V for details on computation of amounts of radionuclides in the streambed.) Inspection of the data in figure 24 and tables 3 and 9 indicates the following:

1. The amount of radionuclides in the streambed as wel1 as the stratigraphic distribution of radionuclides varies considerably among core sites.

2. Estimated total amounts of measured radionuclides (excluding $40_{\mathrm{K}}$ ) at the core sites range from about $0.05 \mu \mathrm{c} / \mathrm{ft}^{2}$ (microcuries per square foot) to $15 \mu \mathrm{c} / \mathrm{ft}^{2}$, and average about $3.6 \mu \mathrm{c} / \mathrm{ft}^{2}$ $\left(\sigma= \pm 3.9 \mu c / \mathrm{ft}^{2}\right)$.

3. On the average, nearly 66 percent of the estimated total amount of measured radionuclides at core sites occurs in the upper 8 inches of the streambed. However, at some sites radionuclides extend we11 below 60 inches in depth.

4. Radionuclides usually are distributed so that highest concentrations are at the streambed surface or a few inches below the surface. Below the elevation of highest concentrations, the levels of radionuclides decrease with depth either fairly uniformly or very irregularly.

5. Radionuclides tend to be distributed to greater depths in cores located in channels and on slopes than in cores from the flats. 6. As would be expected from the differences in half-life between ${ }^{51} \mathrm{Cr}\left(27.8\right.$ days) and ${ }^{65} \mathrm{Zn}$ (245 days), ${ }^{51_{\mathrm{Cr}}}$ is relatively less abundant in the total sediment column than it is in surficial sediments. However, ${ }^{51} \mathrm{Cr}$ in cores still averages about twice as abundant as the next most abundant radionuclide, ${ }^{65} \mathrm{Zn}$. 
Table 9.--Sumary of the atratigraphic digtribution of measured radionuclides (excluding $40 \mathrm{~K}$ ) In cores from the Columbia River eatuary

[Types of radionaclide distributions: 1, decreasing; 2, increaging then decteasing; 3, inadequately defined; A, regularly; $B$, Irregularly]

\begin{tabular}{|c|c|c|c|c|c|c|c|c|c|}
\hline \multirow{2}{*}{$\begin{array}{l}\text { Core } \\
\text { number }\end{array}$} & \multirow{2}{*}{$\begin{array}{c}\text { Core } \\
\text { lesgth } \\
\text { (lnches) }\end{array}$} & \multirow{2}{*}{$\begin{array}{l}\text { In situ } \\
\text { gross gammo } \\
\text { gedianctivity } \\
\text { (cpw) }\end{array}$} & \multirow{2}{*}{$\begin{array}{l}\text { Number of } \\
\text { segrients } \\
\text { apalyzed }\end{array}$} & \multirow{2}{*}{$\begin{array}{l}\text { Estimated depth } \\
\text { to which } \\
\text { radionuclides } \\
\text { extend } \\
\text { (1nches) }\end{array}$} & \multirow{2}{*}{$\begin{array}{c}\text { Type of } \\
\text { etratigraphif } \\
\text { distribution } \\
\text { of } \\
\text { radionuclides }\end{array}$} & \multirow{2}{*}{$\begin{array}{l}\text { Computed } \\
\text { cotal anount of } \\
\text { meanured radio- } \\
\text { nuclidas at } \\
\text { core site } \\
\left(\mu \mathrm{ft} \mathrm{ft}^{2}\right)\end{array}$} & \multirow{2}{*}{$\begin{array}{l}\text { Percent of total } \\
\text { mesured radio- } \\
\text { muclideg in } \\
\text { upper inches }\end{array}$} & \multicolumn{2}{|c|}{$\begin{array}{l}\text { Percent } \\
\text { of tatal mensured } \\
\text { radionuclsdeo }\end{array}$} \\
\hline & & & & & & & & $2 n-65$ & $c r-51$ \\
\hline c366 & 11 & 44,200 & 10 & 37 & 3 & 7.40 & 42.8 & 28.5 & 58.1 \\
\hline c367 & 41 & 29,900 & 15 & 39 & $2 B$ & 2.68 & 44.0 & 21.3 & 70.8 \\
\hline$C 3671$ & 42 & 29,900 & 8 & 39 & 18 & 2.48 & 39.6 & 21.0 & 66.3 \\
\hline C368 & 59 & 31,200 & 8 & 24 & $\mathbf{1 A}$ & 2.97 & 81.1 & 23.6 & 69.7 \\
\hline c369 & 47 & 56,700 & 10 & 24 & $2 \mathrm{~A}$ & 3,78 & 91.0 & 23.5 & 70.1 \\
\hline C370 & 40 & 4,900 & 8 & 26 & $\mathbf{1 A}_{\mathbf{A}}$ & 1.10 & 51.8 & 33.6 & 52.7 \\
\hline c371 & 50 & 14,400 & 10 & 76 & 1B & 12.97 & 9.2 & 31.9 & 61.7 \\
\hline c372 & 54 & 7,600 & 10 & 6 & $2 \lambda$ & .46 & 98.9 & 21.3 & 68.1 \\
\hline $\mathrm{c} 373$ & 47 & 88,600 & 11 & 46 & 18 & 7.82 & 65.7 & 17.4 & 64.9 \\
\hline c375 & 52 & 7,400 & 12 & 41 & $1 B$ & 3.48 & 50.3 & 36.5 & 47.7 \\
\hline $\mathrm{c} 376$ & 55 & 25,400 & 13 & 11 & $\mathbf{l n}$ & 1.95 & 92.8 & 21.5 & 64.6 \\
\hline c337 & 63 & 98,900 & 16 & 10 & $1 \mathrm{~B}$ & 1.61 & 98.8 & 21.1 & 67.7 \\
\hline c378 & 63 & 130,000 & 15 & 23 & $2 \AA$ & 6.84 & 96.6 & 38.9 & 53.4 \\
\hline $\mathrm{C} 37 \mathrm{~s}$ & 58 & 34,900 & 13 & 14 & 1B & .80 & 69.2 & 62.5 & $\cdots$ \\
\hline c380 & 47 & 10,500 & 9 & 52 & 18 & 4.51 & 20.8 & 40.4 & 44.3 \\
\hline c38I & 64 & 106,000 & 16 & 64 & 2B & 15.30 & 46.7 & 37.7 & 42.8 \\
\hline C382 & 23 & 5,500 & 11 & 24 & 18 & .60 & 54.2 & 35.0 & 42.8 \\
\hline C383 & 11 & 7,500 & 6 & 6 & 3 & .045 & 100.0 & 22.2 & $-\cdots$ \\
\hline c3B4 & 48 & 7,900 & 7 & 72 & 18 & 6.28 & 8.6 & 3.5 & 84.7 \\
\hline c385 & 42 & 10,900 & 10 & 54 & LA & 2.02 & 31.2 & 49.5 & 13.4 \\
\hline C3B6 & 58 & 9,800 & 10 & 42 & $2 A$ & 1.75 & 75.4 & 58.8 & $\cdots$ \\
\hline C387 & 46 & 14,100 & 8 & 26 & $1 B$ & 1.20 & 85.0 & 14.2 & 70.3 \\
\hline c387I & 46 & 14,100 & 5 & 24 & 18 & 1.36 & 75.7 & 14.7 & 83.8 \\
\hline c388 & 66 & 8,500 & g & 6 & $2 \mathrm{~A}$ & .65 & 100.0 & 13.2 & 83.1 \\
\hline c389 & $\$ 2$ & 6,200 & 9 & 9 & $1 \mathbf{A}$ & .84 & 97.6 & 11.0 & 85.0 \\
\hline
\end{tabular}




\section{SEDIMENT COMPOSITION AND RADIONUCLIDE CONTENT}

In a previous section, possible relations between sediment composition and radionuclide content have been mentioned. The composition of the bed material is characterized by the particle-size distribution, mineralogy, and organic content of the sediment. These characteristics largely fix other variables, such as surface area, cation-exchange capacity, and state of aggregation, and can influence the chemical character of surrounding media. Many studies have shown that certain changes in composition usually are accompanied by specific changes in other characteristics of the sediment. For exauple, it is well known that a decrease in particle size is generally accompanied by increases in surface area and cation-exchange capacity, and also quite likely by a change in mineralogy. Differences in almost any aspect of sediment composition will almost certainly result in differences in the quantity of radionuclides associated with the sediment.

Sufficient data were collected during the 1965 survey to evaluate directly the relations between radioactivity and certain statistics that describe particle-size distributions. Three such statistics are plotted (fig. 25) against the total concentration of measured radionuclides (less $40_{\mathrm{K}}$ ). Figure 25 indicates that radioactivity increases as (1) mean size decreases (phi increases), (2) dispersion increases (deviation measure increases), and (3) skewness of the distribution changes from negative to positive.

Considerable scatter exists between the various general relations shown in figure 25. The scatter can be caused by many things, including (1) differences among samples, in any aspect of sediment composition, that are not reflected in the particle-size statistics either because 
DEVIATION OR SKEWNESS MEASURE, IN PHI UNITS

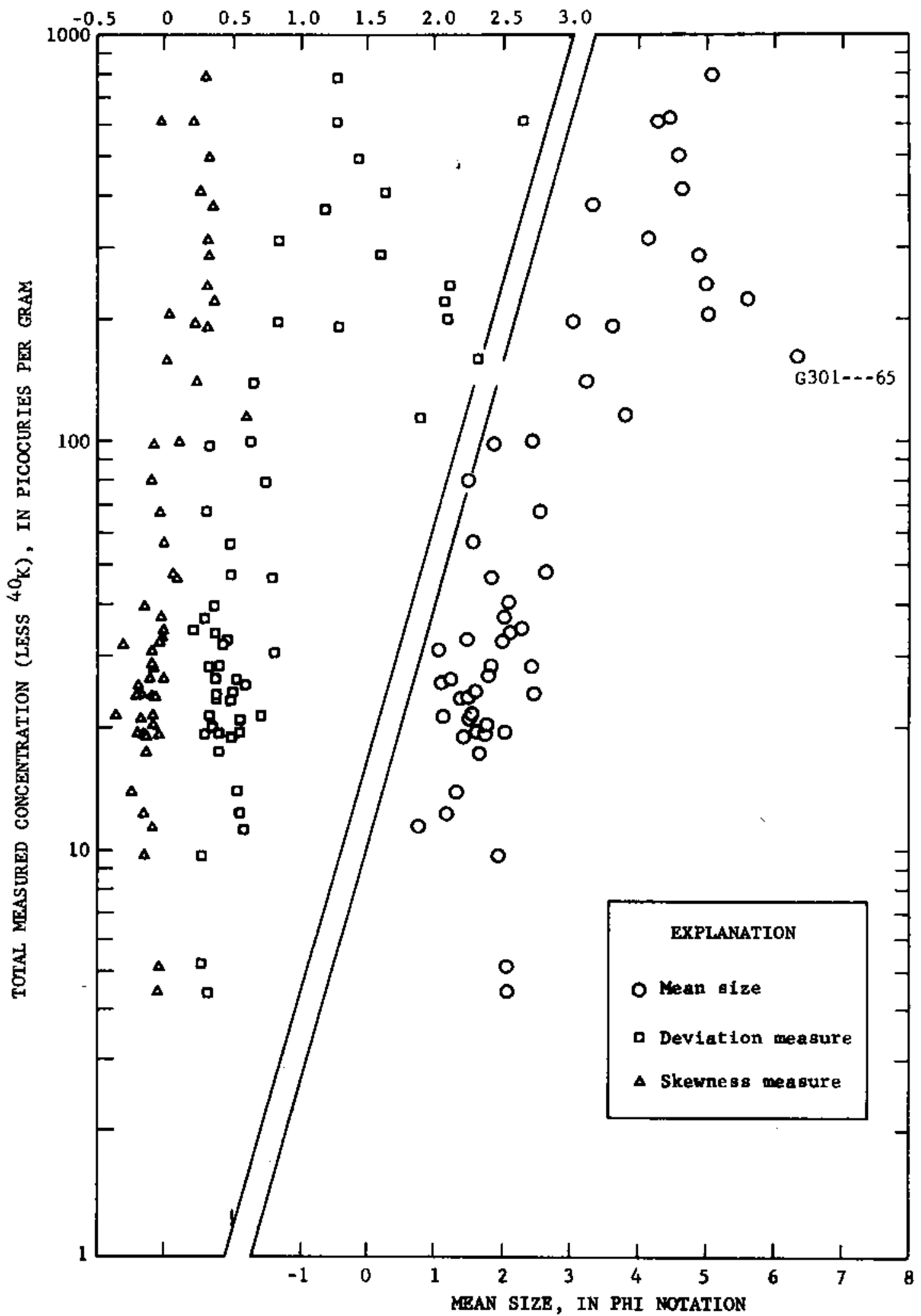

Pigure 25.--Variation of the total concentration of measured radionuclides (1ess $\left.40^{\circ}\right)$ In ourficial sediment with different texture statistics. 
the statistics lack sensitivity or because the variable does not influence the statistics appreciably; (2) errors inherent in both particle size and redionuclide analyses; (3) normal, random variations; and (4) differences in the amount of radionuclides present that are independent of sediment composition. Although none of these possible causes can be evaluated adequately with available data, possible trends in lateral and longitudinal variations in radionuclide concentrations in the estuary, suggested in previous sections, imply that a family of curves would be necessary to describe relations between radioactivity and particle size at different locations. To illustrate, the point that represents sample G301---65 in the right-hand part of figure 25 is among the farthest removed from a line that could be drawn to depict an average relation between mean size and the total concentration of measured radionuclides. This sample apparently contains a much lower radionuclide concentration than other samples with a similar mean size. Sample G301--65 was collected (pl. 2) at a lateral position more than 4 miles from the main Columbia River channel and near the mouth of a tributary that contributes sediments with very low radionuclide concentrations. Its position alone, then, is sufficient reason for the relatively low radionuclide concentration. If samples with a wide range of mean sizes were collected from this location and were analyzed for radionuclides, a curve, offset somewhat to the right but generally parallel to one for all samples, would probably result.

Under comparable conditions, the sorption capacity of sediment for most cations is roughly proportional to the available surface area (Sayre and others, 1963). Surface area, expressed in terms of specific surface, is sometimes approximated from a calculated value (Baver, 1956). 
By assuming that all particles in a given size range have the same diameter and that all particles in a sample are spheres of specific gravity 2.65, an estimate of specific surface can be obtained from

$$
\text { Sp. S. }=\sum_{i=1}^{n} 22.64 \frac{f_{i}}{D_{i}}
$$

where

Sp. S. is the specific surface of a sediment mixture, in square centimeters per gram;

22.64 is a units-conversion constant;

$\mathrm{D}_{i} \quad$ is the geometric mean size, in millimeters, of the ith size range;

$f_{1}$ is the fraction, by weight, that sediment in the ith size range is of the total sample; and

n is the total number of size ranges in the mixture.

Specific surface is plotted against ${ }^{65} \mathrm{Zn}$ concentration in figure 26 to illustrate the relationship for Columbia River sediments. Because both specific surface and size statistics are determined from the same particle-stze data, similar relations with radionuclides should exist-the degree of similarity would depend on how well the particle-size statistics and specific-surface estimates correlate. Despite the grossness of the specific-surface model, specific surface should be more sensitive to radionuclide content than any single size statistic. Comparison of figure 25 with figure 26 , however, suggests that both specific surface and mean size correlate about equally well with radionuclide concentrations. As in figure 25, the largest deviations on the specificsurface plot (fig. 26) appear to reflect principally locational variations in radionuclide content that are not related to physical size of the sediment. 


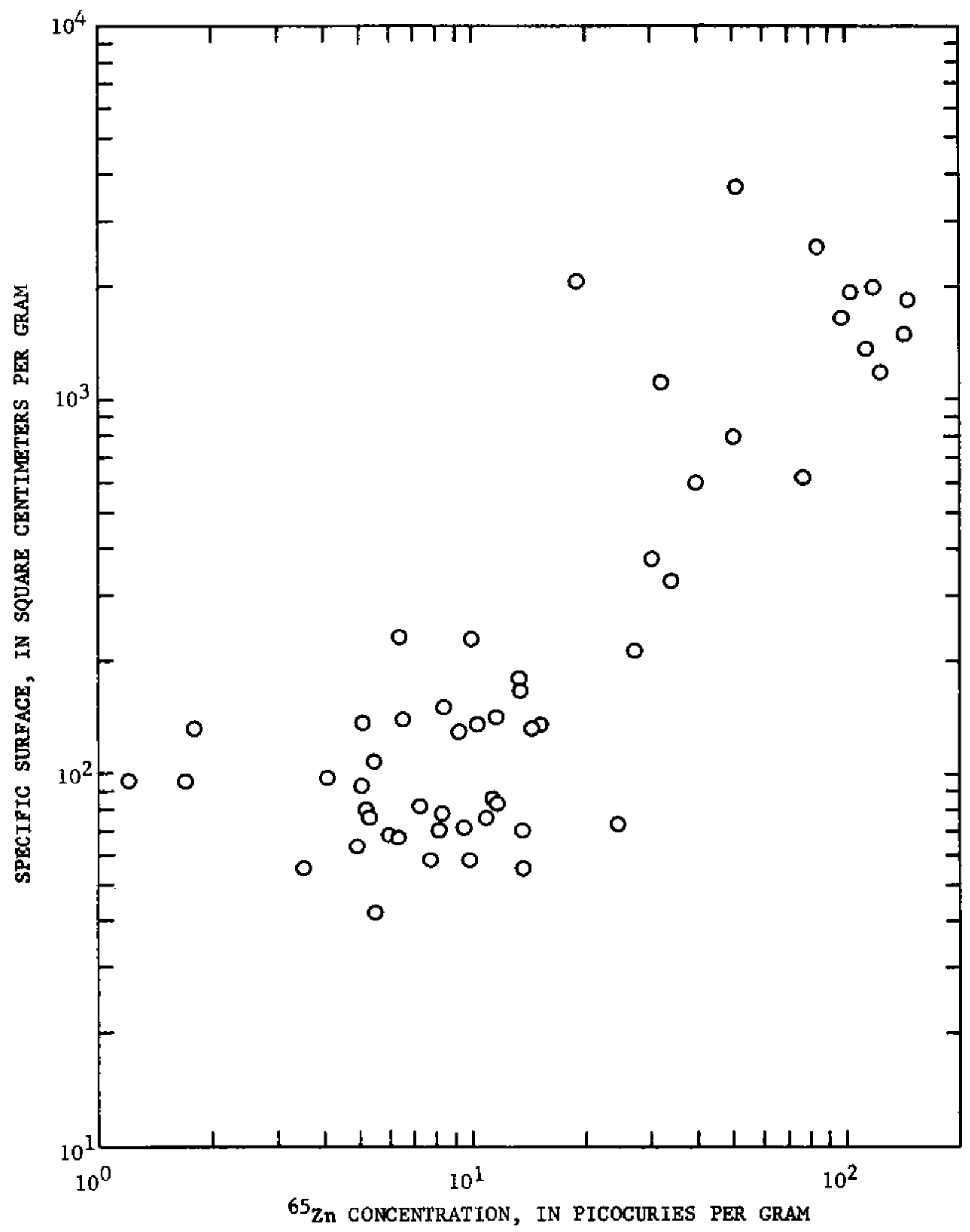

Figure 26.--Variation of ${ }^{65} \mathrm{Zn}$ concentration in surficial sediment with speciflc surface. 
The possibility of locational variations in radionuclide concentrations has been mentioned in previous sections. One of the factors that complicates the delineation of any trends is spatial variations in sediment composition that necessitate, for example, comparing radionuclide concentrations in coarse silt at one location with radionuclide concentrations in sand at another location. This difficulty can be overcome partly by considering the locational variation in radionuclide content associated with only the sediment within an individual size range. Although radionuclide concentrations for individual size separates are not directly available from this survey, they can be approximated from the radionuclide and size analyses of the surficial sediment by utilizing general relations between mean size and radionuclide concentration (figs. 25 and 27). Assume that (1) regardless of location or level of activity, the ratio between the radionuclide concentration of any given narrow size range and the concentration of any other narrow size range in a sediment mixture is constant (the ratio may be different for every different pair of size ranges) and (2) the ratios of concentration between size ranges are defined for total measured radionuclide concentrations (less ${ }^{40} \mathrm{~K}$ ) by an average curve that could be drawn in figure 25 and by the curve in figure 27 for concentrations of ${ }^{65} \mathrm{Zn}$. These assumptions imply that if radionuclide concentrations associated with each narrow size range in the bed sediment were available from a number of different locations in the estuary, the data would plot as a 


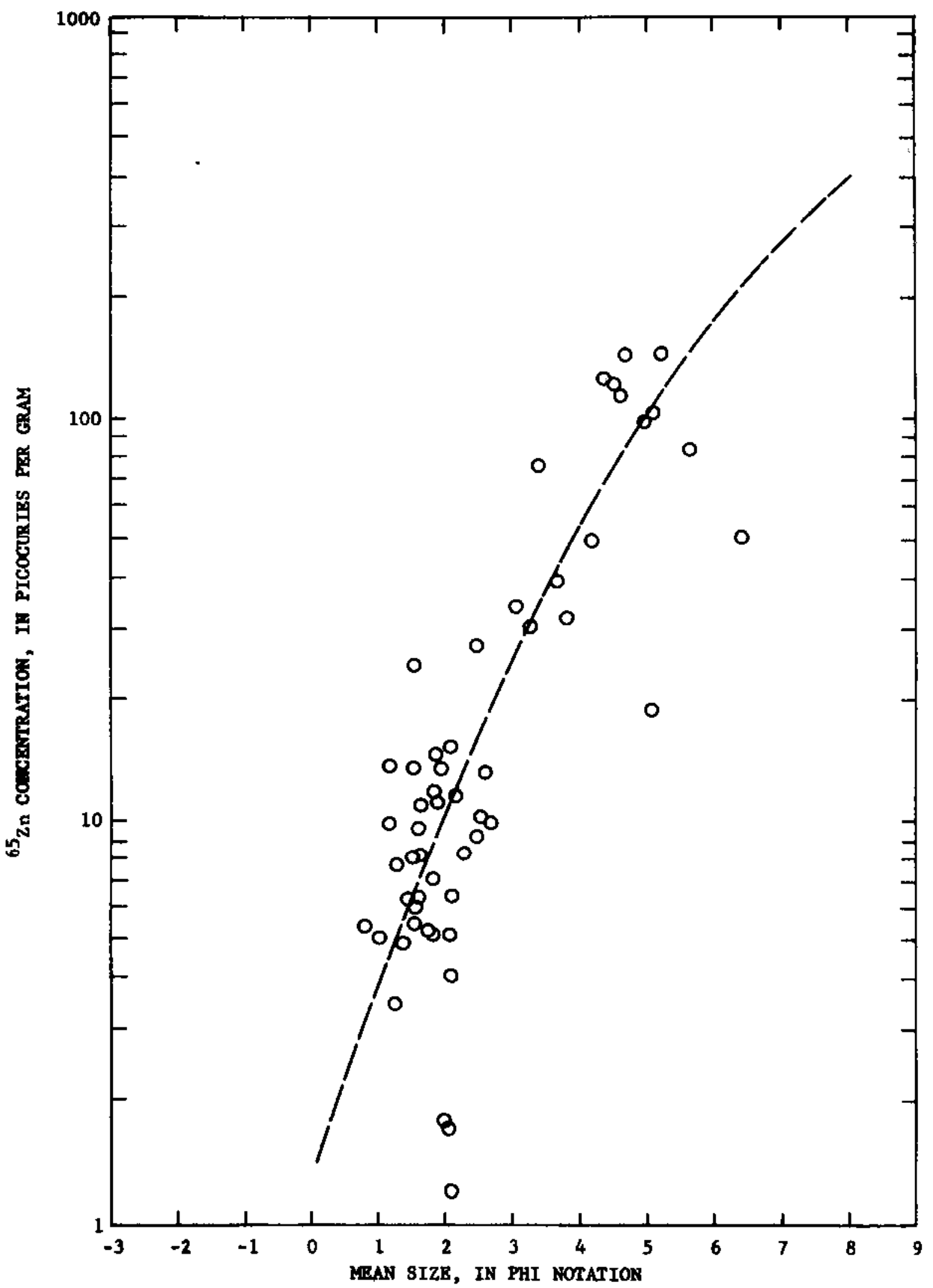

Figure 27.--Variation of ${ }^{65} \mathrm{Zn}$ concentration in surfictal sediment with mean particle size. 
family of curves paralle1 to the curves in figures 25 and 27 . With these assumptions, for any individual sediment sample

$$
\begin{aligned}
c_{t} & =\sum_{i=1}^{n} f_{i} c_{i} \\
& =\sum_{i=1}^{n} f_{i} a_{i} c_{r} \\
& =c_{r} \sum_{i=1}^{n} f_{i} a_{i}
\end{aligned}
$$

where

$c_{t}$ is the concentration of a radionuclide (or radionuclides) in the total sample;

$\mathbf{f}_{i} \quad$ is the fraction, by weight, that the sediment in the ith size range is of the total sample;

$\mathrm{C}_{1}$ is the concentration of a radionuclide (or radionuclides) in the ith size range;

n is the total number of size ranges in the mixture;

$\mathrm{C}_{\mathbf{r}}$ is the concentration of a radionuclide (or radionuclides) in a reference size (which may or may not be actually present in the sample); and

$a_{i}$ is the ratio of the concentration in the ith individual size range to the concentration of the reference size $\left(C_{i} / C_{r}\right)$.

Values for $a_{i}$ can be determined from the curves of figures 25 or 27 by selecting for each size range a single size to represent the entire size range--in this analysis the geometric mean is used to represent the size range. If the reference size is taken as that size for which the radionuclide concentration is $1.0 \mathrm{pc} / \mathrm{g}$, then the value of "a" for each 
size range equals the concentration at the geometric mean of the size range.

By solving equation 2 for $C_{r}$, the concentrations for each size range can be determined from $C_{1}=a_{1} C_{r}, C_{2}=a_{2} c_{r}$, and so forth. Concentrations of ${ }^{65} \mathrm{Zn}$ were obtained in this manner for each standard size range from all samples in each cross section for which both the size distribution and radionuclide content were defined. Whenever concentrations for a size range were available from more than one sample at a cross section, they were combined to give an average concentration for the range. As a result, the concentrations are based on different numbers of values from one size range to the next and from one cross section to the next. At each cross section, the concentration of ${ }^{65} \mathrm{Zn}$ genera1ly decreased progressively as the size increased, although discontinuities exist in this trend as a result of averaging different numbers of values from one range to another. Despite the shortconings and inexactness of the procedure, the data suggest that the concentration of ${ }^{65} \mathrm{Zn}$ associated with the geometric mean of any particular size range decreases progressively between Longview and the estuary mouth. This trend is shown in figure 28 for geometric means of several size ranges. The individual concentrations at a given river mile should not be given undue signiflcance because they often are based on a very limfted amount of data. Some implications that can be inferred from the plots are discussed in a following section of this report. 


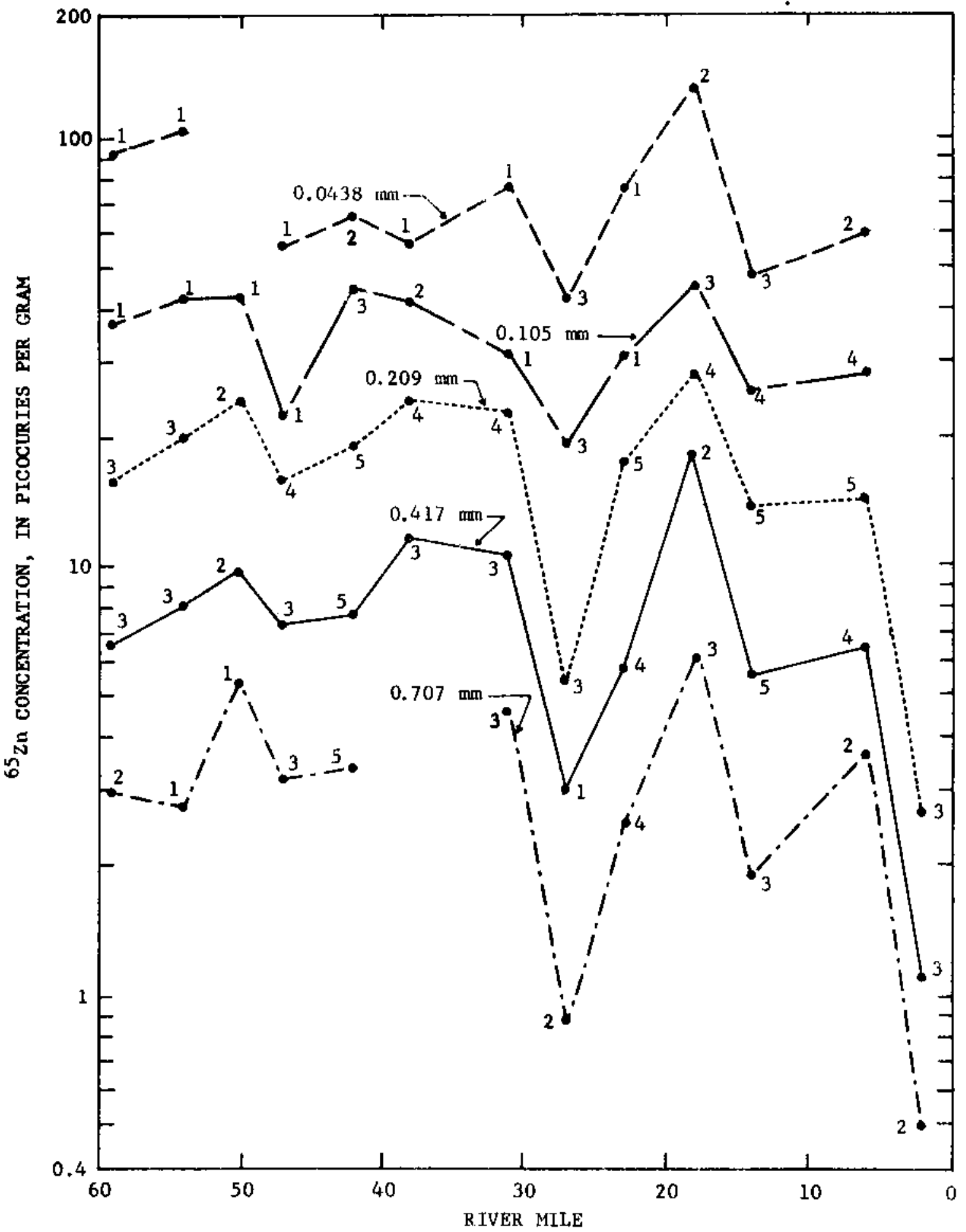

Figure 28.--Attenuation of ${ }^{65} \mathrm{zn}$ concentration associated with individual size separates with distance along the estuary. The individual size separates of surficial sediment are identified by the geometric mean size. The number of samples uaed to determine average value for each point ia adjacent to the point. 
GENERALIZED QUALITATIVE DESCRIPTION OF THE DISTRIBUTION OF

RADIONUCLIDES IN THE ESTUARY

The specific relations and trends presented in the previous sections, together with information on the morphology of the estuary bed during the survey and throughout the year, provide the basis for a generalized qualitative description of the distribution of radionuclides in the estuary.

As a result of the influence of texture on the physico-chemical properties of the sediment, radionuclide concentrations and areal distributions of radionuclides are largely determined by the areal distribution of sediment particles. In channels and on some slopes and flats where the flow velocities are relatively high and active sediment transport occurs at the bed, fine particles are winnowed from the bed so that the sediment is fairly coarse and radionuclide concentrations are low. On most slopes and flats and in some abandoned channels where the flow velocities are generally low, or where circulation patterns promote deposition, the bed sediment is relatively fine and concentrations of radionuclides are highest.

The depth and distribution of radionuclides in estuary environments depend on the previous history of the bed surface; however, percolation of river water in the bed sediments, in situ chemical reactions, and the activities of burrowing organisms and other biota may alter the original depositional patterns. In most areas of the estuary, deposition does not proceed continuously but is intermittent or alternates with scouring periods. The magnitudes and rates at which the depositional and erosional processes occur depend on channel geometry, sediment texture, and local flow characteristics. 
In the upper part of the estuary, flow is contained mainly within one or two we11-defined channels. In these channe1s, sandy botton sediment often is formed into trains of dunes. Depending upon local flow conditions, dunes may have mean heights and lengths as sma11 as 2 and 30 feet or as large as 15 and 600 feet, respectively. The ratios of length to height vary considerably, but average about 50; dune heights rarely exceed 20 percent of the channel depth. During times of high flow, dunes achieve maximum height and progress downstream as a result of the erosion of particles on the foreslope and deposition on the backslope. This process causes the bed surface to alternately rise and fall as dunes move by, and distributes radionuclides throughout the channel bed from the troughs to the crests of the dunes. Usually in a channel dune area, only insignificant amounts of fine sediment remain in the bed sediment and, as a result, the concentrations of radionuclides are low. However, often there is a tendency for fine particles to settle in the dune troughs. This deposition creates, at the elevations of the troughs, bands of fine sediment that are approximately parallel to the water surface. Because migrating dunes, even in the same dune area, often have variable crest and trough elevations, the bands of fine sediment occur at various depths in the streambed thus causing the texture of the sediment and the concentration of the radionuclides to vary stratigraphica1ly. In areas of actively moving dunes, particles are periodically exposed and buried so that the "age" of the sediment at one elevation may be approximately the same as at every other level in the dune. With this condition, decay does not influence the stratigraphic variations in radionuclide content; however, where particles are trapped in a part of the bed that no longer moves or moves only very infrequently, the 
residence time of the particle affects the level of radioactivity. Often, small dunes migrate at relatively rapid rates along the foreslopes of large dunes. With this condition, the distribution of radionuclides might be fairly uniform over the depth of the small dunes and then decrease substantially within the body of the large dune.

When the flow is low, little if any sediment transport occurs along the bed. Dune heights appear to reduce somewhat, probably in response to localized scour and deposition; fine material may accumulate at the bed surface and the radionuclide concentration may increase according $1 \mathrm{y}$.

Around bars, at channel margins, on the insides of bends, and on channel slopes, dunes are relatively small and the bed sediment is somewhat finer than in the channels, probably as a result of the moderate velocities and secondary circulation. In such areas radionuclide concentrations are proportionately high.

Where flow is essentially impounded, rather than conveyed, such as on wide shallow flats and in sloughs, fine sand, stlt, clay, and organic matter tend to accumulate and produce a fine-textured bed. Concentrations of radionuclides in these areas are higher than in areas of coarser sediment. Although deposition is more or less a continuous process on flats and in sloughs, except possibly for an infrequent scouring phase, the net accumulation of sediment with time ordinarily is relatively slow; hence, radionuclides remain fairly close to the surface.

In the estuary below Harrington Point, the flow is less channelized and tends to spread out over vast shallow flats. Because of moderate velocities and wave action over these flats, the bed remains relatively free of silt and clay. Deposition of fine sediment occurs in the 
remnants of former channe1s that are closed at the ends and in large bays. The depth and distribution of the radionuclides follow the same general trends as in the upper estuary. However, the bed forms are less well-defined and their migration patterns probably are different because of the tendency for a net flow of zero or an upstream flow to persist at the bed. Bed relief rarely exceeds 3 feet and the forms tend to be more rounded than dunes formed upstream.

The influence that saline water in the lower part of the estuary has on concentrations of radionuclides in the sediment is not readily apparent from the available data, principally because of a scarcity of data and the overriding variations in the texture of the sadiment. Any effects of flocculation and subsequent settling of sediment that may result from salinity intrusion also are not readily discernible.

\section{RADIONUC LIDE INVENTORY}

Information on the areal and stratigraphic distributions of radionuclides in the streambed has been used to make an "inventory" of radionuclides in the estuary. Two maps were prepared for the inventory: one shows the distribution of different surficial levels of radioactivity, and the other reflects the disposition of different stratigraphic distributions of radionuclides. Because in situ count rates provide radioactivity data with the greatest areal density, they were used to prepare the surficial activity-level map. This map divides the estuary bed into divisions in which count rates are estimated to be $10,000 \mathrm{cpm}$ or less, 10,000 to $20,000 \mathrm{cpm}$, and greater than $20,000 \mathrm{cpm}$. The ranges of count rates that delineate the divisions were selected to allow maximum use of relations among geomorphic class, particle size, and activity levels. Generally, count rates of $10,000 \mathrm{cpm}$ and less came from channels and 
flats where flow velocities may be relatively high; rates of 10,000 to $20,000 \mathrm{cpm}$ came from slopes and flats where velocities are moderate; and counts greater than $20,000 \mathrm{cpm}$ came from flats, "dead" channels, and sheltered slopes where velocities are low. These basic relations were utilized to map count-rate divisions between data points in each cross section and to extend cross-section data to all areas between cross sections.

Although surficial activity-level divisions are indicative of the genera1 amounts of radioactivity in the bed, they are only an index to the total depth and stratigraphic distribution of radionuclides. In order to account for variations in radioactivity that result from different vertical distributions, the estuary was divided into sections in which radionuclides were estimated to have one of three different stratigraphic distributions. The boundaries between sections approximately coincide with those separating geomorphic classes (channels, slopes, and flats) that have been described previously. The radionuclide data from cores generally indicate that stratigraphic distributions differ (p. 73) between geomorphic classes, and the generalized discussion (p. 84-87) of processes active in each class suggests mechanisms whereby different distributions could result.

A final map was produced by combining the areal and stratigraphic maps to form a map with nine kinds of subdivisions, each of which represented areas having a common general level of activity near the surface and a common stratigraphic distribution of radionuclides. The individual areas were measured with a polar planimeter and sumed to give the area of each subdivision. 
In order to relate in situ count rates to an actual amount of radionuclides, the relations given in figures 20 and 21 were used. The influence that different stratigraphic distributions of radionuclides had on the computation was introduced by determining from the core samples in each geomorphic class the mean percentage of the total amount of radionuclides in the bed that resided in the upper 8 inches. Percentages were determined on a unit-area basis.

To compute the amount of radionuclides in the bed, the mean amount of radionuclides per unit area in the upper 8 inches in each of the three count-rate divisions was obtained from either figure 20 or 21 by determining the amount that corresponded with the average in situ count rate of all data points included in all the areas encompassed by each count-rate division. Then, for each of the nine combined areal-stratigraphic subdivisions, the mean amount of radionuclides in the upper 8 inches was divided by the mean percentage of radionuclides in the upper 8 inches for the stratigraphic class of the subdivision so as to yield the mean amount of radionuclides per unit of surface area in the subdivision. This value was then multiplied by the total area to give the amount of radionuclides in the subdivision, and the amounts from all subdivisions were accumulated to give an overall total. In order to reflect possible longitudinal changes in the amounts of radionuclides, the estuary was divided lengthwise into eight reaches and the computations were carried out to provide the amount of radionuclides in each reach.

Three different computations were made. One is of the total amount of measured radionuclides (exclusive of $40 \mathrm{~K}$ ) and the other two are of the amounts of ${ }^{65} \mathrm{Zn}$ and $51_{\mathrm{Cr}}$. For each computation, average in situ count 
rates in the three count-rate divisions were determined to be $7,100 \mathrm{cpm}$, $14,000 \mathrm{cpm}$, and $53,400 \mathrm{cpm}$. These average rates represent total amounts of measured radionuclides in the upper 8 inches of $5.2 \times 10^{-7}, 12 \times 10^{-7}$, and $35 \times 10^{-7}$ curies per square foot (fig. 20). Comparable values for ${ }^{65} \mathrm{Zn}$ and ${ }^{51} \mathrm{Cr}$ are $9.3 \times 10^{-8}, 24 \times 10^{-8}$, and $102 \times 10^{-8}$ curies per square foot, and $42 \times 10^{-8}, 80 \times 10^{-8}$, and $220 \times 10^{-8}$ curies per square foot, respectively (fig. 21). Core samples indicated that the percentage of total measured radionuclides in the upper 8 inches in channel areas ranged from 9 to 54 and averaged 36; in slope areas, the percentages ranged from 21 to 99 and averaged 70; and in flat areas, the percentage ranged from 98 to 100 and averaged 99 . Comparable percentages for ${ }^{65} \mathrm{Zn}$ averaged 32, 72, and 99 and ranged from 6 to 43,24 to 100 , and 99 to 100 for the channels, slopes, and flats, respectively. For ${ }^{51} \mathrm{Cr}$, percentages averaged 66,74 , and 96 and varied from 10 to 97,26 to 100 , and 93 to 100, respectively.

Amounts of radionuclides in each reach of the estuary from the three computations are listed in table 10, and cumulative distributions of radionuclides downstream from CRM 65.8 are shown in figure 29. These data indicate that the total amount of measured radionuclides in the estuary (excluding $40 \mathrm{~K}$ ) is about 8,700 curies. Of this amount, about 2,100 curies (24 percent) is ${ }^{65} \mathrm{Zn}$ and 5,300 curies (61 percent) is ${ }^{51} \mathrm{Cr}$. The remaining 1,300 curies (15 percent) is comprised about equally of other activation radionuclides $\left({ }^{46} \mathrm{Sc},{ }^{54} \mathrm{Mn},{ }^{60} \mathrm{Co}\right)$ and fallout $\left({ }^{95} \mathrm{Zr}-{ }^{95} \mathrm{Nb},{ }^{106} \mathrm{Ru}\right)$.

Approximately 15 percent of the total amount of measured radionuclides is between CRM 0 and 7.8 (marine environment), 48 percent is between CRM 7.8 and 23.2 (transition environment), and 37 percent is 
Table 10.--Inventory of measured radionuclidea in the Columbia River entuary

\begin{tabular}{|c|c|c|c|c|c|c|c|c|c|c|c|c|c|c|c|c|}
\hline \multirow{3}{*}{$\begin{array}{l}\text { Long1tudinal } \\
\text { division }\end{array}$} & \multirow{3}{*}{$\begin{array}{l}\text { Reach } \\
\text { I1mits } \\
\text { (river } \\
\text { m1le) }\end{array}$} & \multicolumn{5}{|c|}{ Total mengured radionuc lides } & \multicolumn{5}{|c|}{$21 n c-65$} & \multicolumn{5}{|c|}{ Chrom1um-S1 } \\
\hline & & \multicolumn{3}{|c|}{ In geomorphic class } & \multicolumn{2}{|c|}{$\begin{array}{c}\text { In all } \\
\text { geomorphic classen }\end{array}$} & \multicolumn{3}{|c|}{ In geomorphic class } & \multicolumn{2}{|c|}{$\begin{array}{c}\text { In all } \\
\text { geomorphic clasaes }\end{array}$} & \multicolumn{3}{|c|}{ In geomorphic clasa } & \multicolumn{2}{|c|}{$\begin{array}{c}\text { In all } \\
\text { geomorph1c classes }\end{array}$} \\
\hline & & $\begin{array}{l}\text { Channels } \\
\text { (curies) }\end{array}$ & $\begin{array}{c}\text { Slopes } \\
\text { (curles) }\end{array}$ & $\begin{array}{l}\text { Tlats } \\
\text { (curies) }\end{array}$ & Amount & $\begin{array}{l}\text { Percent of } \\
\text { totel in } \\
\text { eatuary }\end{array}$ & $\begin{array}{l}\text { Channels } \\
\text { (curies) }\end{array}$ & $\begin{array}{l}\text { Slopes } \\
\text { (cur1es) }\end{array}$ & $\begin{array}{l}\text { Plats } \\
\text { (curtes) }\end{array}$ & $\underset{\text { Amount }}{\text { (cur1e } B \text { ) }}$ & $\begin{array}{l}\text { Percent of } \\
\text { totel in } \\
\text { egtuary }\end{array}$ & $\begin{array}{l}\text { Channels } \\
\text { (curles) }\end{array}$ & $\begin{array}{l}\text { Slopes } \\
\text { (curfes) }\end{array}$ & $\begin{array}{l}\text { Flats } \\
\text { (curtes) }\end{array}$ & $\begin{array}{l}\text { Arrount } \\
\text { (cur 1es) }\end{array}$ & $\begin{array}{l}\text { Percent of } \\
\text { total in } \\
\text { estuary }\end{array}$ \\
\hline Fluvial -... & $55.2-65.8$ & 170 & 110 & 180 & 460 & 5.3 & 35 & 24 & 46 & 105 & 5.1 & 76 & 76 & 118 & 270 & 5.1 \\
\hline 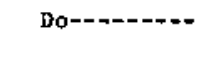 & $46.2-55.2$ & 180 & 82 & 65 & 327 & 3.7 & 39 & 16 & 14 & 69 & 3.4 & 75 & 61 & 47 & 183 & 3.5 \\
\hline 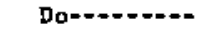 & $34.2-46.2$ & 190 & 180 & 290 & 660 & 7.5 & 39 & 37 & 74 & 150 & 7.3 & 84 & 128 & 191 & 403 & 7.6 \\
\hline Dow.-..... & $27.3-34.2$ & 210 & 190 & 500 & 900 & 10.3 & 47 & 45 & 120 & 212 & 10.3 & 86 & 126 & 328 & 540 & 10.2 \\
\hline Dow......... & $23.2-27.3$ & 160 & 240 & 500 & 900 & 10.3 & 35 & 59 & 120 & 214 & 10.4 & 66 & 155 & 334 & 555 & 10.5 \\
\hline Trane1tion -- & $18.1-23.2$ & 440 & 790 & 860 & 2,090 & 23.9 & 120 & 190 & 210 & 520 & 25.3 & 168 & 499 & 592 & 1,259 & 23.7 \\
\hline 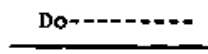 & $7,8-18,1$ & 530 & 1,100 & 500 & 2,130 & 24.4 & 120 & 260 & 120 & 500 & 24.3 & 206 & 688 & 349 & 1,243 & 23.4 \\
\hline Marine & 0.7 .8 & 140 & 470 & 670 & 1,280 & 14.6 & 29 & 90 & 170 & 289 & 14.0 & 61 & 336 & 453 & 850 & 16.0 \\
\hline A11 & $0-65.8$ & 2,020 & 3,162 & 3,565 & 8,747 & 100 & 464 & 721 & 874 & 2,059 & 100 & 822 & 2,069 & 2,412 & 5,303 & 100 \\
\hline
\end{tabular}




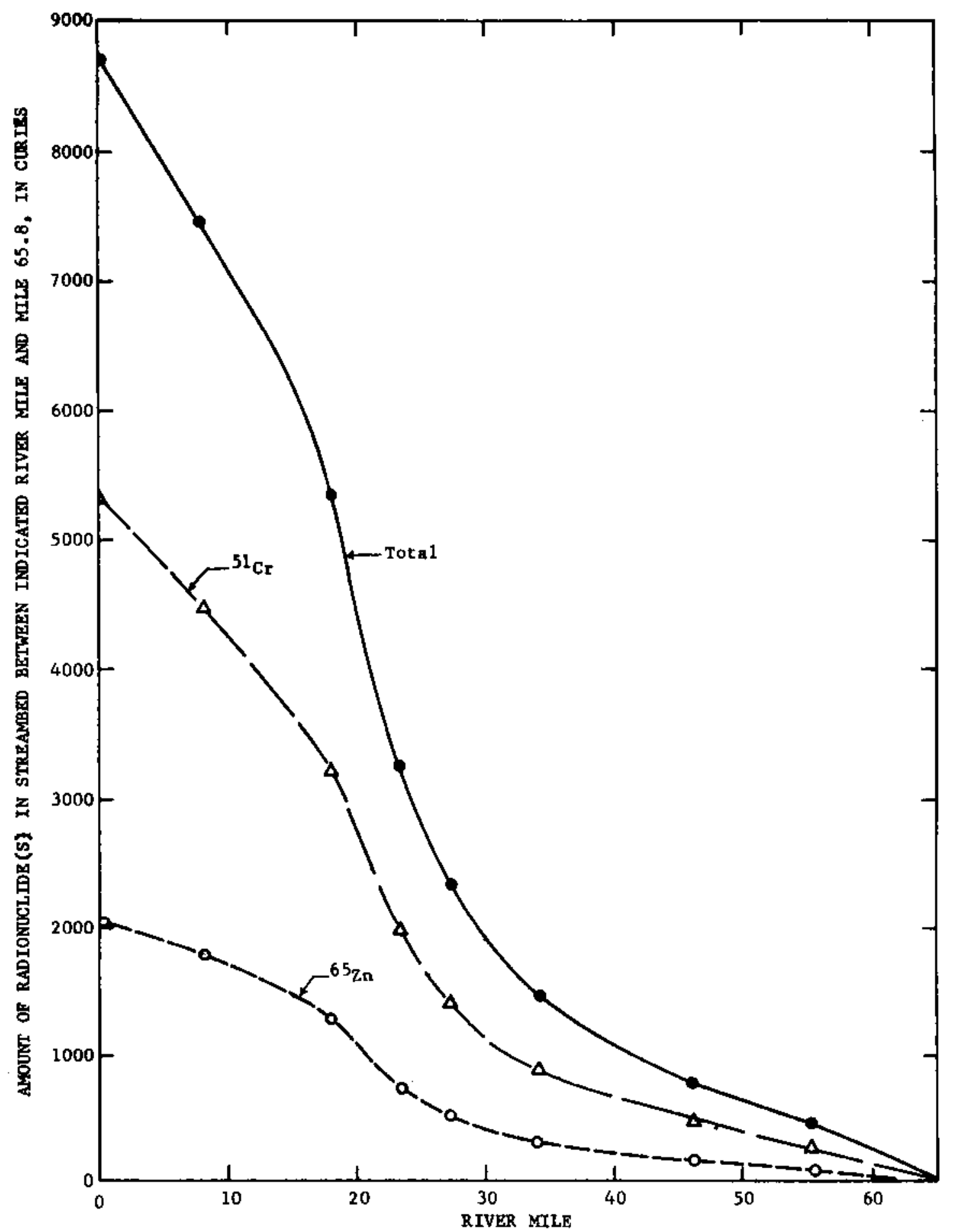

F1gure 29.--Cumblative distribution of the amounts of total mensured radionuclides, $65_{\mathrm{Zn}}$, and $51_{\mathrm{Cr}}$ in the streambed of the Columbia Rtver estuary. 
between CRM 23.2 and 65.8 (fluvial environment). This distribution results primarily from the distribution of surface area, but also reflects differences in mean concentration and in stratigraphic distribution. Approximately 19 percent of the total area of the estuary bed is between CRM 0 and $7.8,43$ percent is between CRM 7.8 and 23.2 , and 38 percent is between CRM 23.2 and 65.8 . The amount of radionuclides per unit area averages nearly 45 curies per square mile for the entire estuary, about 42 curies per square mile for the fluvial environment, 51 curies per square mile for the transition environment, and 36 curies per square mile for the marine environment. The distributions of ${ }^{65} \mathrm{Zn}$ and ${ }^{51} \mathrm{Cr}$ are essentially the same as the distribution of total measured radionuclides; however, proportionately, slightly more $65_{\mathrm{Zn}}$ resides in the transition environment. In the entire estuary, 23 percent of the total amount of measured radionuclides resides in channel areas, 36 percent is in slope areas, and 41 percent is in flat areas.

By weighting the average depth to which radionuclides extend in channels, slopes, and flats with the area of each geomorphic class, it appears that in the fluvial environment radionuclides attain a mean depth of about 2.0 feet; in the transition environment the depth is 1.8 feet, and in the marine environment it is 1.7 feet.

The accuracies of the computed amounts of radionuclides in the estuary cannot be assessed directly because errors assoclated with several steps in the computation procedure cannot be evaluated. Proportionately, the individual amounts are consistent with each other. The ratio of the amount of ${ }^{51} \mathrm{Cr}$ to the amount of ${ }^{65} \mathrm{Zn}$ is 2.5 , and the sum of the two amounts is 85 percent of the total amount of measured radionuclides. Similar ratios of radionuclide concentrations in surficial 
sediments (table 7), adjusted to account for differential decay with depth, show comparable proportions. Additionally, when the mean amount of ${ }^{65} \mathrm{Zn}$ per unit area in the upper 8 inches for each count-rate division is obtained from a relation between the amount of ${ }^{65} \mathrm{Zn}$ per unit area in the upper 8 inches and the amount of total measured radionuclides (less $40_{K}$ ) per unit area in the upper 8 inches (rather than from fig. 21), the computed amount of ${ }^{65} \mathrm{Zn}$ in the estuary is virtually unchanged from that shown in table 10. This consistency suggests that the values selected for the amounts of radionuclides per unit area in the upper 8 inches of the bed within the three count-rate divisions probably are reasonably correct.

The influence of mapping errors that could have been introduced when the estuary was divided into areas of common surficial activities and common stratigraphic distributions is indeterminate. However, because the estuary was divided into approximately 700 units, it seems reasonable, barring any consistent bias, that as a result of combining the units tnto nine subdivisions, mapping errors would not be highly significant.

The mean percentages used to adjust the amount of radionuclides per unit area in the upper 8 inches of the bed to represent the amount of radionuclides per unit area throughout the whole sediment column are another source of error. According to an analysis of the possible error due to these percentages, it can be stated with 90 percent confidence that the computed total amount of radionuclides in the estuary is in error by less than about 25 percent due to the values used in the computations. The computed possible error reflects the limited number of cores from each geomorphic class and the variance in the percentages of 
radlonuclides in the upper 8 inches determined from the cores (hereafter called "adjustment factors").

The analysis is based on the supposition that the percentage error in the amount of radionuclides computed to be in the estuary is the weighted sum of the percentages of error in the amount determined for each geomorphic class; the weighting factor for each class is the fraction that the amount of radionuclides in the class is of the entire amount for al1 classes. Since the amount of radionuclides in each class is the product of the area of the class and the mean amount of radionuclides per unit area in the class, the percentage error for each class (assuming no error in area) is the same as the percentage error, $E$, in the mean amount of radionuclides computed to be in a unit area of the class. By definition

in which

$$
E=100\left[\frac{\frac{A_{8}}{m}-\frac{A_{8}}{\bar{x}}}{\frac{A_{8}}{m}}\right]=100\left(\frac{\bar{x}-m}{\bar{x}}\right)
$$

A $_{8}$ is the mean amount of radionuclides per unit area in the upper 8 inches of the bed;

m is the percentage that gives the true mean of the amount of radionuclides per unit area throughout the whole sediment column in the class. The value of m is unknown, but it is the same as the mean of the means of all possible samples of the adjustment factor of a given size (that is, it is the population mean); and 
$\bar{x}$ is the mean percentage that was used in the inventory computation for a class. The value of $\bar{x}$ is the mean of a sample that includes all available determinations (observations) of adjustment factors in a class.

Although $\mathrm{m}$ is unknown and the actual value of $\mathrm{E}$ cannot be ascertained, the interval wherein m can be expected to lie with a specified confidence coeffictent and sample size is given (Li, 1964) by

$$
\bar{x}-\frac{t s}{\sqrt{N}}<m<\bar{x}+\frac{t s}{\sqrt{N}}
$$

in which

$t \quad$ is "Student's $t$," which varies with percentile points of the t-distribution and the sample size;

$s$ is the standard deviation of the sample; and

$\mathrm{N}$ is the number of observations in the sample (sample size).

Because $\bar{x}-m$ is a maximum at $\pm t s / \sqrt{N}$, the maximum value of $E$ is defined by

$$
E_{\max }=100\left( \pm \frac{t s}{\sqrt{N} \bar{x}}\right) .
$$

When $t$ is taken at the 5 percent point of the $t$-distribution, calculated values of $E_{\max }$ are $66.9,17.1$, and 7.7 percent for the total amount of radionuclides in channels, slopes, and flats classes, respectively. Weighting these percentages in accordance with the proportion of the amount of radionuclides in each class ( p. 93) indicates that the maximum error in the total amount of radionuclides in the estuary which might 
result from the selected adjustment factors is 24.3 percent, or about 25 percent. The comparable computed maximum errors in the amounts of ${ }^{65} \mathrm{Zn}$ and ${ }^{51} \mathrm{Cr}$ in the estuary are about 20 and 30 percent, respectively. Although the maximum probable error in the inventory computations cannot be assessed because several kinds of error cannot be quantified, the error is greater than the maximum error of any single element in the computations. Inasmuch as the adjustment factors alone could contribute up to 25 percent error, the possible error would exceed this value. Also, aside from the statistical errors, the computed amounts of radionuclides may not be representative of the amounts present throughout the whole of 1965 or in subsequent years. As mentioned previously, surficial activity may be somewhat lower in June than at other times of the year and the general level of activity probably has diminished as a result of the decrease in the number of reactors being operated at Hanford since 1964.

\section{ASPECTS OF SEDIMENT TRANSPORT IN THE ESTUARY}

A knowledge of the amounts of radionuclides in the estuary and of the spatial variations in the concentrations of radionuclides can be used to quantify approximately certain sediment-transport phenomena in the estuary. Almost without exception, however, the approximations depend on assumptions about the uptake and (or) release of radionuclides by the particulate matter in the estuary as well as about other considerations. Unfortunately, the validity of most assumptions cannot be verified. Despite this shortcoming, and with the recognition that computations may be grossly in error, the following analyses are presented in the belief that some of the techniques and conclusions will be beneficial in interpreting sediment-related processes that directly influence the disposition of radionuclides in the estuary. 


\section{Retention of Fine Sediment in the Estuary}

In any given reach of the estuary the rate of change in the amount of radionuclides in the reach equals the difference between the net rate of inflow of radionuclides (inflow minus outflow) and the rate of radionuclide decay in the reach. This relation can be expressed for an individual radionuclide as follows

$$
\frac{\mathrm{dA}}{\mathrm{dt}}=\left(\mathrm{c}_{\mathrm{s}} \mathrm{Q}_{\mathrm{W}}\right)_{\mathrm{I}}-\left(\mathrm{c}_{\mathrm{s}} \mathrm{Q}_{\mathrm{W}}\right)_{0}+\left(\mathrm{c}_{\mathrm{f}} \mathrm{Q}_{\mathrm{f}}\right)_{\mathrm{I}}-\left(\mathrm{c}_{\mathrm{f}} \mathrm{Qf}_{\mathrm{f}}\right)_{0}+\left(\mathrm{c}_{\mathrm{c}} \mathrm{Q}_{\mathrm{c}}\right)_{\mathrm{I}}-\left(\mathrm{c}_{\mathrm{c}} \mathrm{Q}_{\mathrm{c}}\right)_{0}-\lambda_{\mathrm{A}}
$$

where

A is the amount of the radionuclide in the reach at any given time, $t$;

$\mathrm{C}_{\mathrm{S}}, \mathrm{C}_{\mathrm{f}}, \mathrm{C}_{\mathrm{c}}$ are the concentrations of the radionuclide in solution and associated with the fine and coarse sediment $\underline{1} /$, respectively;

$Q_{w}, Q_{f}, Q_{c}$ are the discharges of water and of $f$ ine and coarse sediment, respectively;

I, 0 are subscripts denoting a quantity that is coming in or going out of the reach, respectively; and $\lambda$ Is the decay coefficient for the radionuclide.

In equation 3

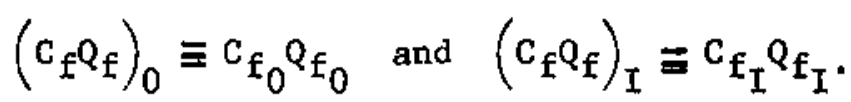

Thus, by setting

$$
\frac{\left(\mathrm{C}_{s} Q_{w}\right)_{0}}{\left(C_{s} Q_{w}\right)_{I}}=k, \quad \frac{{ }^{C_{0}}}{C_{f_{I}}}=c
$$

$\underline{1} /$ Fine sediment is all material, including biota, whose diameter is $\geq \overline{0} .45$ micron and $<62$ microns. Coarse sediment is all material $\geq 62$ microns in diameter. 
and dividing by $\left(C_{F} Q_{F}\right)_{I}$, equation 3 becomes

$$
\left.\left.\frac{d A}{d t}=\left(c_{f} Q_{f}\right)_{I}\left[R_{S}(1-k)+1-c(1-P)+R_{c}-\frac{\left(c_{c} Q_{c}\right.}{\left(C_{f} Q_{f}\right.}\right)_{I} 0-\frac{\lambda_{A}}{\left(C_{f} Q_{f}\right.}\right)_{I}\right]
$$

where

$$
\begin{aligned}
& \left.\frac{\left(\mathrm{C}_{\mathrm{S}} \mathrm{Q}_{\mathrm{W}}\right)_{I}}{\left(\mathrm{C}_{\mathrm{f}} \mathrm{Q}_{\mathrm{f}}\right)_{I}}=\mathrm{R}_{\mathrm{S}}, \quad \frac{\left(\mathrm{C}_{\mathrm{c}} \mathrm{Q}_{\mathrm{C}}\right)_{I}}{\left(\mathrm{C}_{\mathrm{F}} \mathrm{Q}_{\mathrm{f}}\right.}\right)_{I}=R_{\mathrm{C}} \text {, and } \\
& \frac{\mathrm{Q}_{\mathrm{f}_{\mathrm{I}}}-\mathrm{Q}_{\mathrm{f}_{0}}}{\mathrm{Q}_{\mathrm{f}_{I}}}=\mathrm{P} \text { or } \mathrm{Q}_{\mathrm{f}_{0}}=\mathrm{Q}_{\mathrm{f}_{I}}(1-\mathrm{P}) .
\end{aligned}
$$

If equation 4 is applied to the transport and storage of ${ }^{65} \mathrm{Zn}$, it can be reduced with several simplifying assumptions. In the reach between Pasco and Vancouver, the amount of ${ }^{65} \mathrm{Zn}$ in the streambed is essentially constant throughout the year (Nelson and others, 1966; fig. 6). If this condition also exists in the estuary, then $\frac{d A}{d t}=0$. Further, the outflow of ${ }^{65} \mathrm{Zn}$ in association with coarse sediment probably can be considered to be negligible. With these assumptions, equation 4 reduces to

$$
\frac{c+k R_{S}-\left[R_{S}+R_{C}+1-\frac{\lambda_{A}}{\left(C_{f} Q_{f}\right)_{I}}\right]}{c}
$$

in which $P$ is the fraction of the fine sediment inflow that is retained in the estuary.

Based on the following as sumptions, available data on the transport of ${ }^{65} \mathrm{Zn}$ at Vancouver and the computed amount of ${ }^{65} \mathrm{Zn}$ in the estuary can be used to approximate the magnitude of $P$ : (1) The transport rate of ${ }^{65} \mathrm{Zn}$ and the proportion of ${ }^{65} \mathrm{Zn}$ in solution and associated with the particulate matter in transport are not significantly different at Vancouver and Longview (the input station for the estuary); (2) the proportion of 
fine and coarse sediment in transport is essentially the same at Vancouver and Longview; (3) the amount of ${ }^{65} \mathrm{Zn}$ in solution and associated with the suspended-particulate matter in transport in the estuary at any given time is insignfficant relative to the amount of ${ }^{65} \mathrm{Zn}$ in the streambed; (4) the ratio of the discharges of ${ }^{65} \mathrm{Zn}$ in solution coming in and going out of the estuary, $k$, is constant; and (5) the ratio of the concentrations of ${ }^{65} \mathrm{Zn}$ associated with the fine sediment coming in and going out of the estuary, c, is constant.

In order to test the sensitivity of equation 5, values of $P$ were computed by using transport data from several different years together with constant values of $k, c$, and the computed amount of ${ }^{65} \mathrm{Zn}$ in the estuary. Use of equation 5 in this manner implies that the constant amount of $65_{\mathrm{Zn}}$ is maintained wholly by variations in the transport of fine sediment going out of the estuary. This condition probably does not exist, but it may be met sufficiently for practical purposes. A detailed explanation of the variables in equation 5 and their values is given in appendix VI.

Computed values of $\mathrm{P}$ along with pertinent basic data for calendar years 1961-64 and the period January 1965 through June 1965 are listed in table 11. Also included in the table are values of $P$ computed for 1961 and 1964 with hypothetical amounts of ${ }^{65} \mathrm{Zn} 20$ percent higher and 20 percent lower than the actual computed amount. During 1963 and 1964, when the mean dally inflows of $65 \mathrm{Zn}$ associated with the fine sediment and the computed amount of ${ }^{65} \mathrm{Zn}$ would have been most nearly in balance, $P$ averaged about 32 percent. The mean daily inflow for 1965 is somewhat high because it does not reflect inflow during the second half of the year, which typically is substantially lower than the first half. As a 
Table 11.--Computation of fraction of fine sediment (P) retalned in the Columbia River estuary

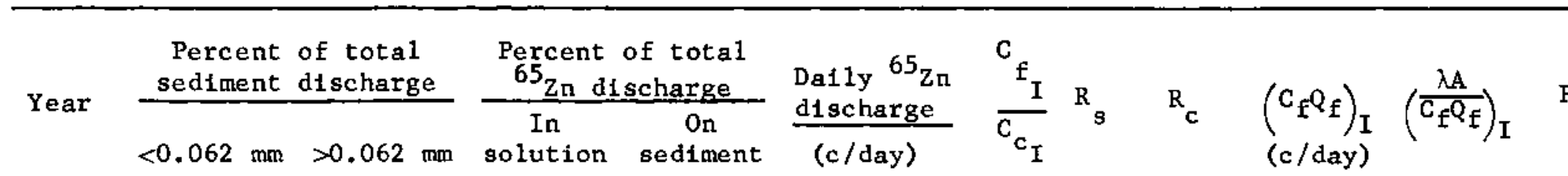

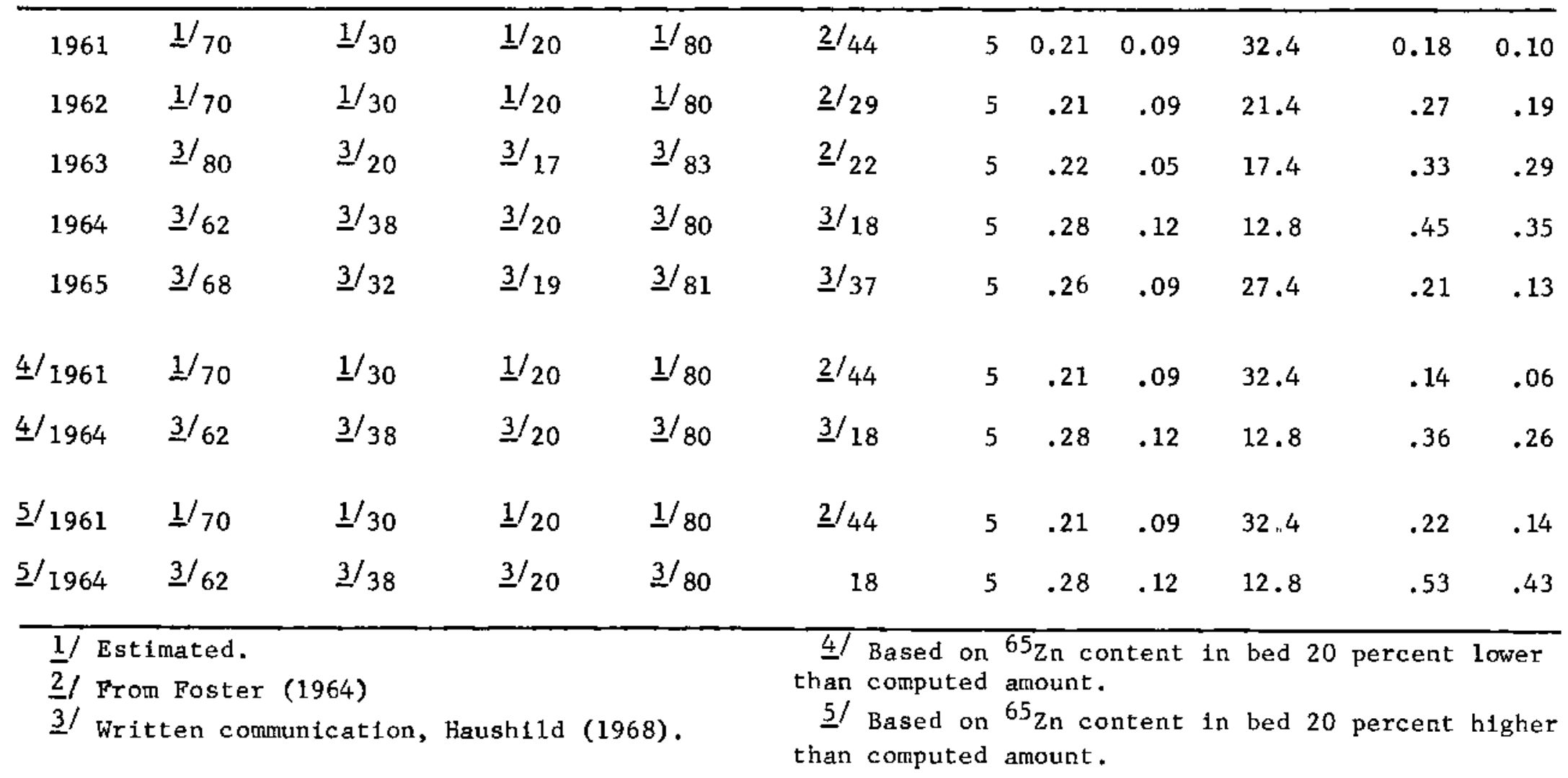


result, the value of $\mathrm{P}$ is lower than would have been computed for the whole year. Values of $P$ computed for 1961 and 1962 also probably are low because the actual amount of $65 \mathrm{Zn}$ at that time very 1ikely was greater than 2,059 curies as a result of the higher inflow of ${ }^{65} \mathrm{Zn}$. Although the computations are not conclusive, they suggest that on an annual basis approximately 30 percent of the fine sediment that enters the estuary is retained there.

The computations show that values of $P$ are relatively insensitive to variations in the transport variables; for a change from 12.8 to 32.4 curies per day ( 153 percent increase) in the inflow of ${ }^{65} \mathrm{Zn}$ associated with fine sediment, the percentage of fine sediment that must be retained in the estuary to maintain 2,059 curies decreases only from 35 percent to 10 percent. Apparently, the amount of the radionuclide in the bed affects the computed values of $\mathrm{P}$ to a much greater degree than do variations in the inflow of ${ }^{65} \mathrm{Zn}$ associated with the fine sediment. Still, the hypothetical 20-percent variations in the amount of $65_{\mathrm{Zn}}$ in the bed caused $\mathbf{P}$ to change on the average only about 7 percent. Given a knowledge of the percent of fine sediment retained in the estuary, equation 5 can be used to estimate the amount in the bed associated with any specified (past or future) ${ }^{65} \mathrm{Zn}$ discharge. For instance, by using values of $b, c, k, R_{c}$, and $R_{s}$ as given in appendix $V I$ and table 5 and assuming $P$ equals 0.30 , the amount of ${ }^{65} \mathrm{Zn}$ in 1961 coincident with the annual mean daily ${ }^{65} \mathrm{Zn}$ discharge of $44 \mathrm{c} /$ day would be computed as 4,345 curies.

$\underline{\text { Radionuclide Concentrations and Sediment Transport }}$

Information on the longitudinal attenuation of radionuclide concentrations associated with sediment particles in a given size range (fig. 28) 
provides the potential for computing the mean rate of transport of the particles in the range. Implicit in the computation are the assumptions that (1) the radionuclide concentration associated with the particles changes only as a result of radioactive decay, (2) the particles present at a downstream location ultimately came from upstream, and (3) the concentration used to portray the level of radioactivity associated with the particles of the size range at any location is representative of the concentration associated with all the particles of the size range that may be transported at that location. If these assumptions hold, the difference in the concentrations between two locations is equal to the decay that occurs during the time the particles are transported from the first to the second location; hence, the mean rate of transport of the size range (mean particle velocity), $v_{p}$, can be computed from

$$
\mathrm{v}_{\mathrm{p}}=\mathrm{LT}^{-1}=\mathrm{L}\left(\frac{2.303}{\lambda} \log \frac{\mathrm{C}_{\mathrm{O}}}{\mathrm{c}}\right)^{-1}
$$

where

L is the distance between the two points,

$T$ is the net time required for the particle to move between the two points,

$\lambda$ is the decay coefficient of the radionuclide, and

$\mathrm{C}_{o}$ and $\mathrm{C}$ are the concentrations of the radionuclide associated with the particles of the size range at the inftial and final locations (or times), respectively.

Computations of $v_{p}$ for several size ranges were made by using the average attenuation of ${ }^{65} \mathrm{Zn}$ in the reach between miles 14 and 59 , as defined by regression lines for the data in figure 28 . In general, $v_{p}$ 
decreased as the geometric-mean particle size of the range increased. The regression of the logarithm of $v_{p}$ on the logarithm of geometricmean particle size was defined to achieve a smooth progression. From this relation, values of $v_{p}$ of $3,210,2,920,2,710,2,520$, and 2,390 feet per day were determined for size ranges having geometric-mean particle sizes of $0.0438,0.105,0.209,0.417$, and $0.707 \mathrm{~mm}$, respectively. Throughout most of the reach between miles 14 and 59 , the sediment in the channels (where most of the sediment transport occurs) has a mean particle size of approximately $0.250 \mathrm{~mm}$ and is formed into dunes of various heights. Of the several size ranges for which velocities were computed, only the finest two ranges are transported at times in significant quantities as suspended sediment. The coarser sediment moves predominantly as bedload. With this condition, the particle velocities computed for most of the sediment seem to be inordinately high. Also, when one considers that because of tidal action the flow in the reach at times is either upstream or essentially stagnant, the computed particle velocities seem even more unreasonable. Reasonable values of $v_{p}$ can only be achieved by substantial increases in $\mathrm{C}_{\mathrm{o}} / \mathrm{C}$. That is, $\mathrm{C}_{\mathrm{o}}$ must be higher relative to $\mathrm{C}$, or, conversely, $\mathrm{C}$ must be lower relative to $c_{o}$. The discrepancies suggest that one or more of the underlying assumptions is violated.

Contrary to the first assumption, the possibility exists that radionuclides are exchanged on the sediment particles so that the longitudinal attenuation of concentration is not intimately related to decay. However, available data for ${ }^{65} \mathrm{Zn}$ (Johnson, Cutshall, and Osterberg, 1967) tend to suggest that only small amounts of this nuclide are released at any time. Also, the general decrease in concentrations of ${ }^{65} \mathrm{Zn}$ in 
solution due to progressive dilution toward the mouth of the estuary minimizes the likelihood of additional uptake. In the lower estuary, the influx of littoral drift may dilute the bed mixture with "uncontaminated" particles and thereby cause radionuclide concentrations to be lower than they would be otherwise. This effect negates the second assumption, but since low values of $\mathrm{C}$ promote the computation of more reasonable values of $v_{p}$, dilution of this type cannot be used to explain the discrepancy. Relative to the third assumption, low values of $\mathrm{C}_{\mathrm{o}}$ could result from sampling surficial sediment that contains significant numbers of particles that have been buried for extended periods of time and have unusually low levels of activity due to decay. This effect could result from the migration of large dunes during the spring freshet, which was occurring during the survey, and is most likely to occur in the highly channelized reaches of the upstream part of the estuary.

The change, with time, in the ratio of the concentrations of two different radionuclides also has been used to estimate particle velocities (Gross and Nelson, 1966). The technique is identical to the one used to estimate deposition rates of sediment (see following section), except that the length dimension refers to distance along the channel rather than depth of deposit. The assumptions (p. 107) in both techniques are the same. Using the attenuation of a ratio rather than the attenuation of a single radionuclide has some advantages as we11 as disadvantages. Perhaps the most obvious advantage of a ratio is that the effects of most types of dilution are minimized, with the result that the ratio attenuation may be more closely related to decay. One disadvantage is that the possible effects of uptake and (or) release must be considered for both radionuclides in the ratio. 
Radionuclide concentration ratios for individual size ranges are not available from the data, but the mean ratios for each cross section (table 7) can be utilized to estimate the mean transport rate for the bed-sediment mixture as a whole. Mean ${ }^{65} \mathrm{Zn} /{ }^{60} \mathrm{Co}$ ratios along the estuary (table 7) attenuate approximately 1.5 times in 54 miles. Accordingly, the mean rate of transport is computed as 1,770 feet per day. Although this mean rate for the whole bed mixture is somewhat lower than the rate for the mean particle size in the estuary $(0.208 \mathrm{~mm})$, as estimated from the regression of the logarithm of $v_{p}$ (from equation 6) on the logarithm of size, it also appears to be high. The general agreement between velocities computed by the two different techniques tends to reinforce the conclusion that the concentrations of radionuclides are influenced by factors in addition to radionuclide decay.

\section{Rates of Deposition}

The relative rates of decay between two abundant radionuclides can be used to estimate rates of aggradation. This technique has been used by various investigators, including Nelson, Perkins, Nielsen, and Haushild (1966), who determined deposition rates for Columbia River sediment in McNary Reservolr.

The fundamental equation characterizing radionuclide decay is

$$
A=A_{0} e^{-\lambda T}
$$

where

$A_{0}$ is the amount (or concentration) of a radionuclide at some initia1 time, $t=0$;

A is the amount (or concentration) of the radionuclide at a later time, $\mathrm{t}=\mathrm{T}$; and

$\lambda$ is the decay coefficient for the radionuclide. 
With two radionuclides

$$
\left(\frac{A_{0}}{A_{0}}\right)_{2} \frac{1}{A_{2} e^{\lambda_{2} T}}=\frac{A_{1} e^{\lambda_{1} T}}{A_{2}} e^{\left(\lambda_{1}-\lambda_{2}\right) T} .
$$

Hence,

$$
T=\left(\frac{2.303}{\lambda_{1}-\lambda_{2}}\right) \log \frac{R_{0}}{R}
$$

in which

$$
R_{0}=\frac{\left(A_{0}\right)_{1}}{\left(A_{0}\right)_{2}} \text { and } R=\frac{A_{1}}{A_{2}}
$$

When equation 7 is used to determine a deposition rate, $R_{0}$ and $R$ pertain to the ratios of concentrations of two radionuclides at an initial bed elevation, $d_{o}$, and at a higher elevation, $d$, respectively, such that $d-d_{0}=h$. Hence, equation 7 states, in effect, that the time, $T$, required to deposit sediment within a depth increment, $h$, located between two different elevations in the bed is proportional to the difference between the logarithms of the ratios of the concentrations of the radionuclides at each depth. The net deposition rate during the time interval, $T$, is equal to $h / T$. Implicit in the use of this technique are the assumptions that (1) the ratios of the concentrations of the radionuclides associated with the sediment at the two elevations were equal at the time of deposit, and (2) the changes in the concentrations of the radionuclides during the time interval are due to decay only.

Data in appendixes $I$ and III show that radionuclide ratios in the surficial sediment may vary greatly, even within given areas where the sediment texture and in situ gross-gamma radioactivity are fairly uniform. The variations probably occur partly because in most places 
aggradation is not continuous but is interrupted by periods of degradation. As a result of these alternating processes, particularly if they are related to dune movement, "older" particles that have been buried for some time may be re-exposed and deposited once again at the bed surface. Thus, the ratio that exists at the bed surface depends on the relative "age" of the particles there at the time of sampling and may be unrelatable in terms of decay to ratios in sediment below the surface. When this is the case, deposition rates computed from equation 7 are invalid. Because alternating deposition and erosion are not as likely to occur with fine sediment as with coarse sediment, except possibly at specific locations in the estuary, the most meaningful deposition rates probably can be obtained from cores collected in areas where fine sediment is depositing more or less continuously. of the available cores, $c 373$ seems most likely to satisfy the requirements for a reasonably accurate long-term deposition rate. The sediment is comparatively fine throughout the length of the core, radionuclide ratios change with depth in a consistent manner, and the core was obtalned from an area where continuous deposition probably has been occurring. Figure 30 shows the attenuation of the ${ }^{65} \mathrm{Zn} /{ }^{60}$ Co ratio with depth for this core. The average deposition rate obtained by weighting the computed rate between each pair of defined points with the length of the depth increment is 5.4 inches per year for the upper 11.5 inches of the bed. The net deposition rate, determined from the length of time necessary for the ratio at the surface to become equal to the ratio at the 11.5-inch depth, is 3.4 inches per year. The computed rates, of course, apply only to a local area and should not be assumed to represent a general deposition rate for the whole estuary. 


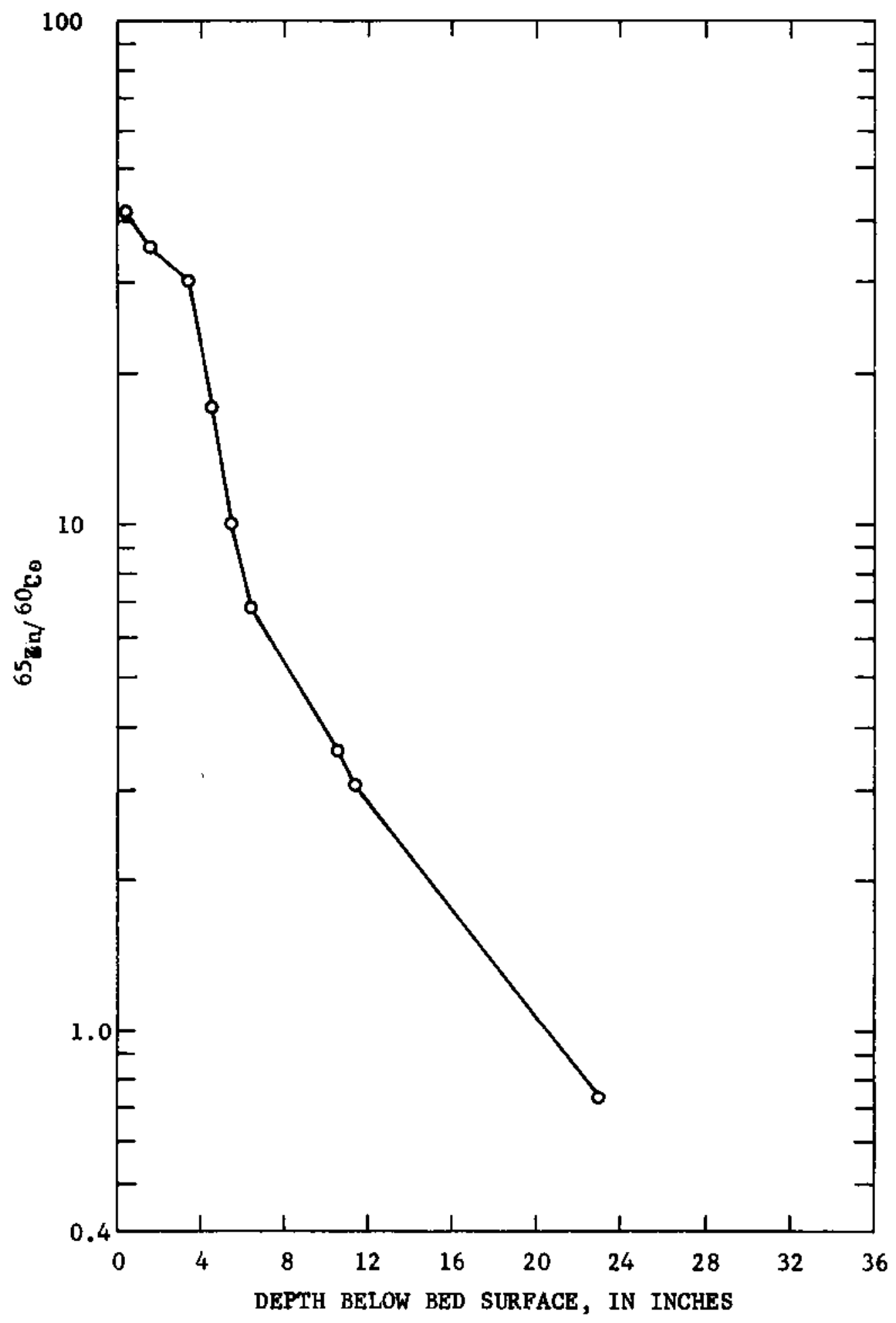

Figure 30.--Variation of ${ }^{65} \mathrm{Zn} /{ }^{60}$ Co ratio with depth in core $\mathrm{C} 373$. 


\section{CONCLUS IONS}

Bed sediment in the Columbia River estuary is predominantly sand $(-1.0<$ phi $\leq 4.0)$; however, textural characteristics vary appreciably throughout the estuary. Clay-size material (phi $\geq 8.0$ ) is sparse, but significant amounts of silt $(4.0<\mathrm{phi}<8,0)$ are present and about 25 per-

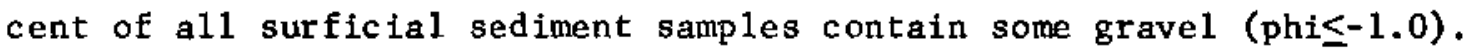
An "average" sediment sample consists of about 1 percent gravel, 84 percent sand, 13 percent silt, and 2 percent clay.

Separating the estuary into geomorphic classes called "channels," "slopes," and "flats" and grouping samples according to class significantly reduces variability of the data and permits comparisons within cross sections and among cross sections. In the estuary as a whole, channel sediments are coarse $\left(M_{\Phi}=1.87\right)$, moderately well sorted $\left(\sigma_{\Phi}=0.75\right)$, and have size distributions that tend to be skewed toward the coarse particles $\left(\alpha_{1 \Phi}=-0.02\right)$; sediments on flats are fine $\left(M_{\Phi}=3.18\right)$, relatively poorly sorted $\left(\sigma_{\Phi}=0.90\right)$, and have distributions skewed toward the fine particles $\left(\alpha_{1 \Phi}=0.17\right)$; and slope sediments are intermediate. From the head to the mouth of the estuary, channe1 sediments appear to become finer and their size distributions become less negatively skewed; sediments on slopes and flats show no significant trends.

A further separation of the estuary into longitudinal divisions in which the dominant processes are fluvial, transitional, and marine in character, facilitates additional comparisons among samples. Within any given division, channels contain sediments with the coarsest particles, flats generally have sediments with the finest particles and the most positively skewed size distributions, slopes generally have the least- 
skewed size distributions, and sediments in all three classes are moderately well sorted. Channel sediments are finest in the transition division and are finer and have more positively skewed size distributions in the marine division than in the fluvial division. Slope sediments have the same textural characteristics throughout the estuary but may be slightly better sorted and have size distributions more positively skewed near the estuary mouth. On flats, sediments are finer in the fluvial and marine divisions than in the transition division, where extensive sand flats occur. In all classes and divisions, the variations in textural characterlstics are large. Elimination of "outlying values" as determined by statistical tests reduces variances but does not affect the previously noted textural trends.

Cores show that sediment texture varies stratigraphically and that strata usually are less than 1 -inch thick. At many locations, sand is overlain with a thin, fine-grained layer. In channels, sediments are fairly homogeneous stratigraphically, but on slopes and flats stratigraphy often is complex. Sediment color varles with depth from brown and green to gray and black. Organic matter occurs either in layers or as individual fragments. In general, sediments in core segments are finer than sediments in surficial samples. Textural differences between core and surficial samples probably reflect a biased selection of core sites rather than a significant textural difference with depth.

About 60 percent of the estuary had in situ gross-gamma count rates of less than $10,000 \mathrm{cpm}$ (background was probably about 2,500 cpm), 19 percent had rates from 10,000 to $20,000 \mathrm{cpm}$, and 21 percent had rates from 20,000 to $142,000 \mathrm{cpm}$. Generally, low count rates occurred in channels whereas count rates varled over a fairly wide range on slopes and flats, 
Both in situ gross-gamma count rates and laboratory gross-gamma count rates of surficial sediment samples correlate well with total measured radionuclide concentrations and with ${ }^{65} \mathrm{Zn}$ concentrations. In situ count rates also correlate fairly well with the amounts of radionuclides per unit area in the upper 8 inches of the bed.

The radionuclides ${ }^{51} \mathrm{Cr},{ }^{65} \mathrm{Zn},{ }^{46} \mathrm{Sc},{ }^{106} \mathrm{Ru},{ }^{54} \mathrm{Mn},{ }^{60} \mathrm{Co}$, and ${ }^{95} \mathrm{Zr}-{ }^{95} \mathrm{Nb}$ are $6.2,2.2,0.2,0.1,0.07,0.06$, and 0.05 times as abundant, respectively, in surficial sediments as naturally occurring $40_{K}$ which averages about $14 \mathrm{pc} / \mathrm{g}$ in estuary sediments that contain little organic material.

Radionuclide concentrations vary greatly throughout the estuary. Genera1ly, concentrations are lowest in channels and highest on slopes and flats. When data from a common division (fluvial, transition, or marine) are combined, standard deviations generally are so large as to preclude positive conclusions about trends in concentration along the estuary. Ratios, however, suggest changes in the relative amounts of some radionuclides; ${ }^{51} \mathrm{Cr}$ appears to increase relative to ${ }^{65} \mathrm{Zn}$ toward the mouth of the estuary.

Sediment texture and organic-matter content combine with sample location to influence the concentration of radionuclides associated with the sediment and to contribute to the variance of concentration within samples from common geomorphic classes or from common longitudinal divisions.

The stratigraphic distributions of radionuclides vary considerably within the estuary. On the average, 66 percent of the total amount of measured radionuclides at core sites is within 8 inches of the bed surface, but at some sites radionuclides extend well below 60 inches. 
Radionuclides tend to be distributed to greater depths in channels and on slopes than on flats. Highest concentrations typically occur at the surface or a few jnches below. Amounts of measured radionuclides (less $40 \mathrm{~K}$ ) in the bed ranged from 0.05 to 15 microcuries per square foot and averaged 3.6 microcuries per square foot. Chromium-51 is relatively less abundant in the sediment column than it is in surficial sediments, but overal1 it averages about twice as abundant as ${ }^{65} \mathrm{Zn}$.

Sediment texture influences the radionuclide content significantly. Radionuclide concentrations increase as the mean size of sediment decreases, as the sediment becomes less well sorted, and as the skewness of the sediment size distribution changes from negative to positive.

Values of specific surface and of mean size computed from particlesize distributions of sediment samples correlate with concentrations of ${ }^{65} \mathrm{Zn}$ about equally well.

Radionuclide concentrations associated with individual size separates were approximated by using radionuclide and size data from surficial samples together with an average relation between mean size and radionuclide concentration. Computations for each cross section suggest that the concentrations of ${ }^{65} \mathrm{Zn}$ associated with different size ranges (represented by the geometric mean) decrease progressively between Longview and the estuary mouth.

Data on the surficial and stratigraphic distributions of radionuclides and sediment texture in association with information on streambed morphology provide a framework for a generalized qualitative description of the distribution of radionuclides in the estuary.

At the time of the 1965 survey, in situ count rates of 7,100 , 14,000 , and $53,400 \mathrm{cpm}$ corresponded to total amounts of measured 
radionuclides in the upper 8 inches of the bed of $5.2 \times 10^{-7}, 12 \times 10^{-7}$, and $35 \times 10^{-7}$ curies per square foot, respectively. The amounts of measured radionuclides in the upper 8 inches averaged 36 percent of the amount of measured radionuclides in the total sediment column in channels, 70 percent in the total column in slopes, and 99 percent in the column on flats.

The total amount of measured radionuclides in the estuary (excluding $40_{K}$ ) in June 1965 was about 8,700 curies of which 61 percent was $51_{\mathrm{Cr}}, 24$ percent was ${ }^{65} \mathrm{Zn}$, and 15 percent was other activation products and fallout. This total amount is about one quarter of the amount that Seymour and Lewis (1964) estimated was in the total reservoir (river, estuary, and ocean) below Vancouver in 1961-63. Approximately 15 percent of the total amount of measured radionuclides was between CRM 0 and 7.8 (marine division), 48 percent was between CRM 7.8 and 23.2 (transition division), and 37 percent was between CRM 23.2 and 65.8 (fluvial division). The amount of measured radionuclides per unit area averaged nearly 45 curies per square mile for the entire estuary, about 42 curies per square mile for the fluvial division, 51 curies per square mile for the transition division, and 36 curies per square mile for the marine division. Channels, slopes, and flats contained 23, 36, and 41 percent, respectively, of the total amount of measured radionuclides. The distributions of ${ }^{65} \mathrm{Zn}$ and ${ }^{51} \mathrm{Cr}$ are essentially the same as the distribution of total measured radionuclides except that, proportlonately, slightly more ${ }^{65} \mathrm{Zn}$ is in the transition division.

The computed inventory may not be representative of the inventory throughout 1965 or in subsequent years because of possible seasonal variations in the amounts of radionuclides stored in the bed and reductions in the number of reactors in operation at Hanford. 
Computations based on transport rates of ${ }^{65} \mathrm{Zn}$ at Vancouver and a mass-balance equation derived from the assumption of a constant amount of ${ }^{65} \mathrm{Zn}$ in the bed, suggest that on an annual basis approximately 30 percent of the fine sediment that enters the estuary is retained there. The computations are relatively insensitive to errors in the transport data and in the quantity of ${ }^{65} \mathrm{Zn}$ in the estuary bed.

Mean particle velocities for individual size separates determined from the attenuation of ${ }^{65} \mathrm{Zn}$ concentration downstream along the estuary are somewhat higher than the mean particle velocity for the whole bed mixture determined from the attenuation of the ${ }^{65} \mathrm{Zn} /{ }^{60} \mathrm{Co}$ ratio. However, overall, the computed velocities seem excessively high. The results reinforce the conclusion that the concentrations of radionuclides in surficial sediments are determined by factors in addition to radioactive decay.

At many core sites, cyclic deposition and erosion precludes accurate computations of deposition rates from the variation of radionuclide ratios with depth. For one core located where conditions appeared to be compatible with the assumptions of the technique, the attenuation of the ${ }^{65} \mathrm{Zn} /{ }^{60} \mathrm{Co}$ ratio with depth gave a net deposition rate of 3.4 inches per year for the upper 11.5 inches of the core.

Relatively low sampling densities, lack of replicate samples and analyses, and incomplete information on the morphology and physicalchemical character of environments throughout the estuary have restricted the extent to which the data could be interpreted. However, despite the deficiencies, available data indicate that information on geomorphic expression and sediment composition can be combined with a knowledge of the types and amounts of radionuclides discharged to provide the basis 
for predicting the probable distribution of radionuclides in rivers and estuaries.

Additional surveys of a similar but more detailed nature should be undertaken to provide data for refining the delineation of significant environmental divisions within the estuary and for 1mproving the definition of seasonal and long-term trends in the radionuclide inventory. 
Barnes, C. A., and Gross, M. G., 1966, Distribution at sea of Columbia River water and its load of radionuclides: Internat. Atomic Energy Agency, Vienna, Symposium on the Disposal of Radioactive Wastes into Seas, Oceans, and Surface Waters, Proc., p. 291-302.

Baver, L. D., 1956, Sol1 Physics [3d ed.]: New York, John Wiley and Sons, Inc., 489 p.

Foster, R. F., 1964, Evaluation of radiological conditions in the vicinity of Hanford for 1963, edited by R. D. Wilson: U.S. Atomic Energy Comm. HW-80991, 198 p.

Gross, M. G., and Nelson, J. L., 1966, Sediment movement on the continental shelf near Washington and Oregon: Sci., v. 154, no. 3750, p. 879-885.

Haushild, W. L., Perkins, R. W., Stevens, H. H. Jr., Dempster, G. R., Jr., and Glenn, J. L., 1966, Progress report: Radionuclide transport of the Columbia River, Pasco to Vancouver, Washington reach, July 1962 to September 1963: U.S. Geo1. Survey open-file rept., $188 \mathrm{p}$. Hembree, C. H., Colby, B. R., Swenson, H. A., and Dav1s, J. R., 1952, Sedimentation and chemical quality of water in the Powder River drainage basin Wyoming and Montana: U.S. Geol. Survey Circ. 170, 92 p.

Ingram, R. L., 1954, Terminology for the thickness of stratification and parting units in sedimentary rocks: Geol. Soc. America Bull., v. 65, p. $937-938$.

Inman, D. I., 1952, Measures for describing the size distribution of sediments: Jour. Sed. Petrology, v. 22, no. 3, p. 125-145. 
Jennings, C. D., 1966, Radioactivity of sediments in the Columbia River estuary: Oregon State Univ. (Corvallis), unpub. M.S. thesis, 62 p. Johnson, Vernon, Cutsha11, Norman, and Osterberg, Charles, 1967, Retention of ${ }^{65} \mathrm{Zn}$ by Columbia River sediment: Water Resources Research, v. 3, no. 1, p. 99-102.

Krumbein, W. C., 1934, Size frequency distributions of sediments: Jour. Sed. Petrology, v. 4, p. 65-77.

Li, J. C. R., 1964, Introduction to statistical inference [2d ed.]: Ann Arbor, Edwards Bros., 553 p.

Lockett, J. B., 1967, Sediment transport and diffusion: Columbia River estuary and entrance: Waterways and Harbors Div. Jour, , ASCE, v. 93, no. WW4, Proc. Paper 5601, p. 167-175.

McManus, D. A., 1963, A criticism of certain usage of the phi-notation: Jour. Sed. Petrology, v. 33, p. 670-674.

Neal, V. T., 1965, A calculation of flushing times and pollution distribution for the Columbia Rlver estuary: Oregon State Univ. (Corvallis) unpub. PHD thesis, $82 \mathrm{p}$.

Nelson, J. L., 1965, Distribution of sediments and associated radionuclides in the Columbia River below Hanford, in AEC research and development report BNWL-36 III: Richland, Washington, Paciflc Northwest Laboratory, p. 3.80-3.88.

1967, Effects of shutdown of the Hanford reactors on radionuclides in bottom sediments of the Columbia River, in $A E C$ research and development report BNWL-481 2: Richland, Washington, Pacific Northwest Laboratory, p. 88-93. 
Nelson, J. L., Perkins, R. W., Nlelsen, J. M., and Haushild, W. L., 1966, Reactions of radionuclides from the Hanford reactors with Columbia River sediments: Internat. Atomic Energy Agency, Vienna, Symposium on the Disposal of Radioactive Wastes into Seas, Oceans, and Surface Waters, Proc., p. 139-161.

Nielsen, J. M., 1963, Behavior of radionuclides in the Columbia River, in Kornegay, B. H., and others, eds., Transport of radionuclides in fresh water systems: U.S. Atomic Energy Comm. Rept. TID-7664, p. 91-112.

Perkins, R. W., 1965, An anticoincidence-shielded multidimensional analyzer: Nuclear Instruments and Methods, v. 33, p. 71-76.

Pritchard, D. W., 1952, Estuarine hydrography: Advances in geophysics, v. 1, p. 243-280.

Prych, E. A., and Hubbe11, D. W., 1966, A sampler for coring sediments in rivers and estuaries: Short Note in Geol. Soc. America Bull., v. 77, P. $549-556$.

Prych, E. A., Hubbe11, D. W., and Glenn, J. L., 1967, New estuarine measurement equipment and techniques: Waterways and Harbors Div. Jour., ASCE, v. 93, no. WW2, Proc. Paper 5219, p. 41-58.

Sayre, W. W., Guy, H. P., and Chamberlain, A. R., 1963, Uptake and transport of radionuclides by stream sediments: U.S. Geol. Survey Prof. Paper $433-\mathrm{A}, 35 \mathrm{p}$.

Sayre, W. W., and Hubbe11, D. W., 1965, Transport and dispersion of labeled bed material, North Loup River, Nebraska: U.S. Geol. Survey Prof. Paper 433-c, 48 p. 
Seymour, A. H., and Lewis, G. B., 1964, Radionuclides of Columbia River origin in marine organisms, sediments, and water collected from coastal and offshore waters of Washington and Oregon, 1961-63: Univ, of Washington, Laboratory of Radiation B1ology, Rept. UWFL-86, $73 \mathrm{p}$.

Shepard, F. P., 1954, Nomenclature based on sand-silt-clay ratios: Jour. Sed. Petrology, v. 24, p. 151-158.

Silker, W. B., 1964, Variations in elemental concentrations in the Columbia River: Limnology and Oceanography, v. 9, no. 4, p. 540-545. Trask, P. D., 1932, Origin and environment of source sediments of petroleum: Houston, Gulf Pub. Co., 323 p.

U.S. Army Corps of Engineers, 1960, Interim report on 1959 current measurement program Columbia River at mouth, Oregon and Washington, volume IV: Portland, Oreg., U.S. Army Engineer Dist., 320 p.

U.S. Coast and Geodetic Survey [no date], Tide tables high and low water predictions, 1965, west coast of North and South America including Hawailan Islands: Washington, U.S. Govt. Printing Office, 224 p. U.S. Geological Survey [no date], Water resources data for Oregon, 1965, part 1. Surface water records: Portland, Oreg., Water Resources Div., U.S. Geol. Survey, 359 p. 1968, Water resources data for Oregon, 1967, part 1. Surface water records: Portland, Oreg., Water Resources Div., U.S. Geol. Survey, 364 p.

U.S. Federal Inter-Agency River Basin Committee, 1941, Methods of analyzing sediment samples, in A study of methods used in measurement and analysis of sediment loads in streams: Rept. 4, 203 p. 
U.S. Inter-Agency Committee on Water Resources, 1957, The development and calibration of the visual-accumulation tube, in A study of methods used in measurement and analysis of sediment loads in streams: Rept. $11,109 \mathrm{p}$.

U.S. Inter-Agency Water Resources Council, 1966, Catalog instruments and reports for fluvial sediment investigations, in A study of methods used in measurement and analysis of sediment loads in streams: Minneapolis Federal Inter-Agency Sedimentation Proj., St. Anthony Falls Hydraulic Lab. Rept. M, 14 p.

Wentworth, C. K., 1922, A scale of grade and class terms for clastic sediments: Jour. Geology, v. 30, p. 377-392. 

Appendix I,--Particle-size atatiotica of aurficial sediment froen the Columbie River eatuary. Statiatica computed according
to Imman (1952) and Trank (1932)

[In situ groses games, in counts per minute]

\begin{tabular}{|c|c|c|c|c|c|c|}
\hline & $\begin{array}{l}\text { PHI VA } \\
\text { OICAIE }\end{array}$ & $\begin{array}{l}\text { LUE AT } \\
0 \text { PC I }\end{array}$ & F IARER & & INMA & N VA \\
\hline SAMPLE MC & $\frac{21}{5}$ & 50 & 95 & NEQN & SOQT A & ALPHI \\
\hline FoL LOW & IING SA & & Fron & & & NEE AR \\
\hline $6202-\cdots-65$ & 2.35 & 1.71 & .00 & 1.61 & .51 & -.20 \\
\hline G203-..ES & 2.15 & 1.43 & -.10 & 1.23 & .66 & -.32 \\
\hline $6226=-650$ & 2.04 & 1.26 & .00 & 1.16 & .59 & -.18 \\
\hline $6205 \cdots-65$ & 1.92 & .81 & -.12 & .87 & .58 & .09 \\
\hline $6207=-65$ & 2.00 & 2.11 & 1.00 & 2.07 & .42 & -.12 \\
\hline $6206-\cdots 65$ & 7.00 & 3.62 & 2.16 & 3.76 & 1.13 & .13 \\
\hline $6208-\ldots 65$ & 7.46 & 3.72 & 2.50 & 3.96 & 1.06 & .22 \\
\hline Fol Low & & MPLES & F EON CI & Ross S & ECTION & NEAR \\
\hline $6220 \cdots+650$ & 2.74 & 2.28 & 1.92 & $2.20^{\circ}$ & .22 & -.00 \\
\hline $6221=-650$ & 2.12 & 1.46 & $\because 42$ & 1.18 & .60 &.,- 40 \\
\hline $6210=--650$ & 16.00 & 5.78 & 4.00 & 7.08 & 2.51 & .52 \\
\hline $6211 \cdots-65^{\circ}$ & 2.00 & 1.36 & .11 & 1.36 & .39 & -.00 \\
\hline $6212--0.550$ & 2.61 & 1.72 & .78 & 1.66 & .49 & -.11 \\
\hline $6218 \ldots-\ldots 5$ & 8.69 & 2.94 & 1.50 & 3.53 & 1.37 & .43 \\
\hline $6219---65$ & 2.10 & 1.30 & .27 & 1.24 & .54 & -.11 \\
\hline $6217---65^{\circ}$ & 2.21 & .61 & -2.54 & -.47 & 2.09 & -.52 \\
\hline $6216-\cdots 65$ & 1.95 & 1.07 & .00 & 1.04 & .62 & -.05 \\
\hline $6215 \ldots-650^{\circ}$ & 2.13 & 1.12 & -6.08 & -.99 & 2.72 & -.77 \\
\hline $6216-1-650$ & 2.10 & 1.38 & -1.00 & 1.14 & .70 & -.35 \\
\hline $6213 \cdots-650$ & 2.31 & 1.58 & .83 & 1.57 & .44 & -.04 \\
\hline $6222 \cdots-650$ & 10.46 & 4.21 & :. 63 & 4.65 & 1.65 & .27 \\
\hline $6223 \cdots-650$ & 9.33 & 4.82 & 3.22 & 5.26 & 1.65 & .27 \\
\hline falion & WING SA & MPLES & FECn Ci & Ross 5 & ECTION & NEAR \\
\hline $6225 \ldots-065$ & 6.66 & 2.89 & 1.76 & 3.36 & 1.20 & .37 \\
\hline $6226=-165^{\circ}$ & 2.04 & 1.03 & -2.18 & .73 & 1.00 & -.31 \\
\hline $6227--655^{\circ}$ & 3.07 & 2.56 & 1.60 & 2,49 & .30 & -.18 \\
\hline $6228--650$ & 3.10 & 2.63 & 2.00 & 2.62 & .30 & -.06 \\
\hline $6229---65$ & 7.64 & 4.06 & 2.05 & 6.26 & .07 & .23 \\
\hline $6232 \cdots-65$ & 3.09 & 2.67 & 2.00 & 2.50 & .31 & .08 \\
\hline $6231 \cdots-65$ & 2.35 & $i, E 6$ & .39 & 1.55 & .56 &. .16 \\
\hline $6230 \ldots-\ldots 50$ & 10.13 & 3.36 & .49 & $3, \in 9$ & 2.21 & .15 \\
\hline FolLOW & ING SA & MPLES & FRCF C & Ross S & ECTION & NEAR \\
\hline $6233 \cdots-65^{\circ}$ &. .54 & -3.12 & $-5.00^{\circ}$ & -2.97 & 1.29 & .11 \\
\hline $6235 \cdots--65$ & 1.84 & 1.13 & -1.00 & .99 & .59 & -24 \\
\hline $6234=\ldots-65$ & 2.19 & 1.46 & .20 & 1.31 & .50 & -.21 \\
\hline $6236 \ldots-\ldots 5$ & 3.10 & 2.02 & .88 & 2.00 &.$\in 6$ & .04 \\
\hline $6237 \cdots-65$ & 2.46 & 1.06 & 1.06 & 1.03 & .38 & -.02 \\
\hline $6238--065^{\circ}$ & 2.64 & 2.02 & 1.56 & 2.07 & .33 & .16 \\
\hline $6239 \ldots-65$ & 2.90 & 2.20 & 1.75 & 2.30 & .32 & .05 \\
\hline $62000=-650$ & 3.06 & 2.47 & 1.17 & 2,43 & .40 & -.09 \\
\hline $6241 \cdots-65$ & 4.66 & 3.16 & 2.40 & 3.24 & .54 & .18 \\
\hline $6262---65$ & 2.72 & 2.25 & 1.70 & 2.25 & .22 & $\therefore 00$ \\
\hline Fol LOW & MING SA & MPLES & Fich C & CROSS S & IECTION & NEAR \\
\hline $6246 \cdots--65$ & 1.77 & .87 & -.42 & .86 & .56 & .06 \\
\hline $6265=--65$ & 1.80 & 1.08 & -.18 & .97 & .57 & .19 \\
\hline $6246=--650$ & 2.14 & 1.60 & .96 & 1.57 & .35 & -.07 \\
\hline $6267 \cdots-650$ & 2.42 & 1.49 & .77 & 1.51 & .45 & .04 \\
\hline $6268--.65$ & 1.86 & .83 & -.20 & .04 & .58 & .03 \\
\hline $6269 \ldots-650$ & 2.07 & 1.36 & .12 & 1.33 & .67 & -.08 \\
\hline $6250--.65$ & 2.38 & 1.89 & 1.16 & 1.86 & .34 & -.09 \\
\hline $6251=--65$ & 2.84 & 2.27 & 1.56 & 2.27 & .32 & $\therefore .0 i$ \\
\hline $6252 \ldots+55^{\circ}$ & 4.84 & 3.00 & 2.50 & 3.25 & .66 & .25 \\
\hline $6243 \cdots-65$ & 2.93 & 2.21 & 1.60 & 2.20 & .33 & .03 \\
\hline Follor & WING SA & MPLES & FSOR C & ROSS S & ECTION & NEAG \\
\hline $626 \epsilon^{\prime} \cdots 65^{\circ}$ & 1.06 & 1.20 & .60 & 1.21 & .37 & .01 \\
\hline $6265 \cdots-\cdots 5$ & 2.00 & 1.29 & .18 & 1.20 & .54 & $\therefore 16$ \\
\hline $6264=--65$ & 1.69 & .76 & $\therefore \Delta 0$ & .75 & .61 & -.01 \\
\hline $6261 \cdots-\cdots 5$ & 2.39 & 1.54 & .31 & 1.45 & .64 & -.15 \\
\hline $6262 \ldots-\cdots 5=$ & 12.70 & 4.80 & 3.22 & 5.30 & $1: 60$ & .36 \\
\hline $6263 \cdots-65$ & 3.15 & 2.41 & 1.81 & 2.06 & .36 & .07 \\
\hline $6259 \cdots-.65$ & 2.37 & 1.02 & .02 & 1.20 & .36 & -.07 \\
\hline $6260-\ldots-65$ & 10.94 & 4.90 & 2.75 & 5.16 & 1.36 & .19 \\
\hline $6255=-65 *$ & 3.25 & 1.70 & .65 & 1.05 & .80 & . \\
\hline $6256---65$ & 2.41 & 1.03 & 1.25 & 1.03 & .35 & .01 \\
\hline $6257-\cdots--65$ & 2.70 & 2.03 & .00 & 1.96 & .47 & $\therefore 15$ \\
\hline $6258 \ldots-65$ & 3.71 & 2.60 & 1.72 & 2.65 & .50 & .09 \\
\hline $6253 \cdots-150$ & 12.40 & 5.33 & 3.50 & 5.81 & 1.67 & .29 \\
\hline $6254=-65 *$ & 10.96 & 4.46 & 1.32 & 6.67 & 2.67 & .00 \\
\hline Falion & WING SA & IMPLES & From $\mathrm{C}$ & Eoss s & EECTION & NEAR \\
\hline $6267 \cdots--65$ & 7.00 & 2.55 & 1.57 & 3.41 & 1.35 & .63 \\
\hline $6268 \ldots . .65$ & 2.20 & 1.20 & a & 1.22 & 6 & $\because 09$ \\
\hline $6269-\cdots 650$ & 2.15 & 1.46 & .92 & 1.49 & .36 & .13 \\
\hline $6270 \ldots-.65$ & 6.62 & 2.46 & 1.78 & 3.43 & 1.30 & .70 \\
\hline $6271 \ldots-\ldots 5$ & 5.69 & 1.72 & .10 & 1.99 & 1.25 & .21 \\
\hline $6272 \cdots-65$ & 2.69 & 2.11 & 1.15 & 2.06 & .37 & -.13 \\
\hline $6273 \ldots-\ldots 5$ & 2.21 & 1.36 & .21 & 1.31 & .53 & -.11 \\
\hline 62760.65 & 2.93 & 2.12 & 1.90 & 2.12 & .30 & .0i \\
\hline $6275 \cdots-\cdots 5$ & 2.29 & 1.74 & .50 & 1.60 & .42 & -.14 \\
\hline $6278 \cdots-65$ & 3.50 & 2.76 & 2.16 & 2.70 & .36 & .06 \\
\hline $6277=\ldots-550$ & 2.21 & -1.12 & -3.00 & -.03 & 2.17 & .13 \\
\hline G276-NES: & 9.60 & 9.36 & 2.50 & 4.90 & 1.62 & .34 \\
\hline FCLLON & WING SA & MPLES & Fsor c & cross & SECIION & NE AR \\
\hline $6287-\ldots 65$ & 2.50 & 1.73 & .17 & 1.05 & .56 & -.14 \\
\hline $6206-\cdots 65$ & 3.15 & 2.31 & 1.60 & 2.35 & .46 & .09 \\
\hline $6205 \cdots-650^{\circ}$ & 2.53 & 1.91 & $i .31$ & 1.93 & .36 & .05 \\
\hline $6204=\cdots-E 5$ & 4.69 & 3.02 & 1.50 & 2.96 & .59 & -.11 \\
\hline$G 2 \theta 2-\cdots E E$ & 2.60 & 1.57 & .10 & 1.50 & .76 & -.09 \\
\hline $6201-\cdots-65$ & 2.95 & 1.63 & .65 & 1.07 & .75 & .32 \\
\hline $6280 \ldots-\ldots 5$ & 1.75 & .83 & $\therefore 47$ & .78 & .60 & -.09 \\
\hline
\end{tabular}

See footnotes at end of table. 
Appendix I.--Particle-size atatiatics of surficial sediment from the Columbis River eotuary. Statiotica computed according

[In oltu gross gamms, in counts per minute]

\begin{tabular}{|c|c|}
\hline & $\begin{array}{l}\text { PHI VA } \\
\text { OICATE }\end{array}$ \\
\hline SAMPLE $M C$ & 5 \\
\hline $\begin{array}{c}6279 \cdots-\cdots 5 \\
6283 \cdots-\cdots 5 \\
\text { FOLLOW }\end{array}$ & $\begin{array}{l}5.00 \\
9.00 \\
\text { OWING } 5 \text { A }\end{array}$ \\
\hline $6200 \cdots-250$ & 2.56 \\
\hline $6289 \cdots-0.65 *$ & $\begin{array}{l}2.12 \\
\end{array}$ \\
\hline $6290-\cdots-65$ & 2.65 \\
\hline $6291 \cdots-65$ & 0.00 \\
\hline $6292 \cdots-65$ & 6.12 \\
\hline $6293 \cdots-65^{\circ}$ & 14.00 \\
\hline $6294=--65$ & 2.56 \\
\hline $6295=--65$ & 2.46 \\
\hline $6296 \cdots-\cdots 5$ & 2.74 \\
\hline $6297-\cdots=65$ & 3.50 \\
\hline $6298---65$ & 2.73 \\
\hline $6299--65^{\circ}$ & 111.87 \\
\hline $6300-\cdots-5$ & 3.00 \\
\hline $6301=-65^{\circ}$ & 11.06 \\
\hline $6302-2-65$ & 5.46 \\
\hline $6315 \cdots-65$ & Wh \\
\hline $6315=-25$ & 2.41 \\
\hline $\begin{array}{l}6316 \cdots-65 \\
6317 \cdots-65\end{array}$ & 2.32 \\
\hline $\begin{array}{l}6317 \ldots-65 \\
6318 \cdots-65\end{array}$ & 8.46 \\
\hline $6318--65$ & $2 \cdot 43$ \\
\hline $6319=-655^{\circ}$ & 2.14 \\
\hline $6320=--65$ & 2.56 \\
\hline $6321--650$ & 9.60 \\
\hline $6322 \cdots-65$ & 2.83 \\
\hline $6323 \cdots=55$ & 2.74 \\
\hline $6326-\cdots-65$ & 2.42 \\
\hline G309...65 & 5.00 \\
\hline $6307-0-65^{\circ}$ & 14.00 \\
\hline $6306 \cdots-65$ & 4.80 \\
\hline $6305--65$ & 2.26 \\
\hline $6304=-65$ & 2.02 \\
\hline $6303---65$ & 7.46 \\
\hline $6308-\cdots 65$ & 4.00 \\
\hline FOLLON & DHING SA \\
\hline $6334-\ldots-65 *$ & 9.87 \\
\hline $6335 \cdots-65$ & 2.65 \\
\hline $6336 \cdots-\cdots 5$ & 2.65 \\
\hline $6338--65$ & 2.13 \\
\hline $6337=-65$ & 3.85 \\
\hline $6325--6-65$ & 2.42 \\
\hline $6326=--65$ & 2.60 \\
\hline $6314=-65$ & 2.35 \\
\hline $6313=-65$ & 2.23 \\
\hline $6312=-65$ & 2.20 \\
\hline$G 311 \cdots-\ldots E$ & 8.00 \\
\hline $6310 \ldots 65$ & 7.66 \\
\hline FOLtOr & DWING SA \\
\hline $6363 \cdots-65$ & 2.60 \\
\hline $6364-1-65^{*}$ & 8.49 \\
\hline $6344-2-65$ & 9.87 \\
\hline $6345-\cdots-85$ & 6.00 \\
\hline $6366=-654$ & 3.00 \\
\hline $6347=-65$ & 3.28 \\
\hline $6368 \ldots-65$ & 2.26 \\
\hline $6349-\cdots-65$ & 2.88 \\
\hline $6332 \cdots-65$ & 5.20 \\
\hline $6331=65$ & 2.17 \\
\hline $6330=-65^{*}$ & 10.94 \\
\hline G329-..-E5 & 2.93 \\
\hline $6328---65$ & 2.94 \\
\hline $6327 \ldots-650$ & 3.12 \\
\hline FOLLON & JING SA \\
\hline $6352--65$ & 6.69 \\
\hline $6353 \cdots-250$ & 12.40 \\
\hline $6351=-65$ & 6.62 \\
\hline $6350---650$ & 11.41 \\
\hline $6354=-65^{\circ}$ & 12.93 \\
\hline $6356-\cdots--65 *$ & 11.37 \\
\hline $6355 \ldots-65^{*}$ & 9.60 \\
\hline $6357=-65$ & 4.62 \\
\hline $6358 \cdots-65$ & 2.19 \\
\hline $6359-\cdots-65$ & 2.60 \\
\hline $6360-\cdots-65$ & 2.38 \\
\hline $6361=-65$ & 2.50 \\
\hline $6362 \cdots-65$ & 5.46 \\
\hline $6363 \cdots-65$ & 3.00 \\
\hline $6364 \ldots-05$ & 5.00 \\
\hline $6365=-65$ & 2.42 \\
\hline FOLLOK & WING SAI \\
\hline G339- - - E5 & 9.00 \\
\hline $6340 \cdots-0.650$ & 2.53 \\
\hline $6341=-65$ & 2.44 \\
\hline $6362 \cdots-65$ & 2.60 \\
\hline MISCEL & LLANEOU: \\
\hline $6 \quad 62 \cdots-t_{4}$ & 3.39 \\
\hline $6 \quad 63-\cdots-64$ & 2.95 \\
\hline $6 \quad 64=--64$ & 6.62 \\
\hline $695=-64$ & 2.35 \\
\hline $696-\cdots 64^{\circ}$ & 9.56 \\
\hline $6101=-64$ & 3.13 \\
\hline $6107=-264$ & 6.00 \\
\hline $6109-\cdots 64$ & 2.50 \\
\hline G135-DEG & 6.64 \\
\hline $6139---64$ & 6.00 \\
\hline
\end{tabular}

- higher order statistics for this sample mat be in error

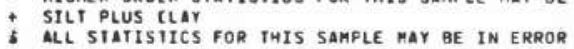


Appendix II, - Particle-size scatistics of selected segmente of cores from the Columb is River eotuary. Statiotica

\begin{tabular}{|c|c|c|c|c|c|c|c|c|c|c|c|c|}
\hline & $\begin{array}{l}\text { PHI VA } \\
\text { DLGAL }\end{array}$ & $\begin{array}{l}\text { LUE AT } \\
\text { id PGI }\end{array}$ & F INAEX & & INMA & IAN VAL & LUES & & $\begin{array}{l}\text { TKAS } \\
\text { YALS }\end{array}$ & $\begin{array}{l}\text { SK } \\
\text { UES }\end{array}$ & & PERGE: \\
\hline JAAPLE NO & 5 & 50 & 15 & MEAN & SORT A & $A L P H I$ & ALPM2 & $\overline{B E T A}$ & SORT & SKEW & GRAVEL & SANO \\
\hline FOLL & a is & $\alpha t$ & Fit & RO & N & AEAR & col Umy & & IER MIL & $E 64$ & & \\
\hline $\cos \theta 3=-0=10$ & $10.5 y$ & 6.91 & 4.30 & 7.16 & 1.91 & .33 & .19 & .60 & 2.522 & . $\rightarrow 14$ & & 3 \\
\hline 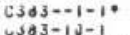 & $10.3 y$ & 6.08 & 1.19 & 6.86 & 2.15 & $=.01$ & -.51 & 1.14 & 2.729 & 1.011 & & i \\
\hline rolcon & $\ln \ln 60$ & KE (S) & FROM C & koss 5 & 5 CIIION & NEAR & COLUME & IA RIV & IER MIL & E 54 & & \\
\hline $\cos \theta 4=-0=11^{\circ}$ & 2.01 & 1.83 & .10 & 1.74 & .58 & -13 & $-.50^{\circ}$ & .64 & 1.311 & 1.060 & & 100 \\
\hline C304--3-10 & 2.30 & $1.3 y$ & .73 & 1.69 & .53 & .00 & .09 & .54 & 1.305 & .967 & & 100 \\
\hline $6386=-5-1$. & c. 30 & 1.59 & .60 & 1.55 & .51 & -.00 & -.12 & .68 & 1.263 & 1.035 & & 100 \\
\hline C $304=+0-2$ & 2.92 & 2.39 & 1.75 & 2.37 & .33 & -.01 & -.19 & .81 & 1.167 & 1.002 & & 100 \\
\hline rocium & WING iv & recisi & FKOM C & Russ? & SECIION & NEAK & COLUNB & IA Riv & IER MIL & E So & & \\
\hline C3OS $=-0-10$ & 5.83 & 2.48 & 1.90 & 2.56 & $\leftrightarrow 0$ & .20 & 3.67 & 3.90 & 1.206 &.+30 & & $\boldsymbol{2}$ \\
\hline C305 - - - - 1 & 2.81 & 2.33 & $1.7 \mathrm{a}$ & 2.33 & .29 & -200 & -.12 & .75 & 1.146 & 1.000 & & 100 \\
\hline $0385-11-10$ & $<.6<$ & 2.20 & 1.60 & 2.14 & .27 & -.05 & -.23 & .79 & 1.125 & 1.000 & & 100 \\
\hline $\operatorname{cis} \theta>-<<-2^{\circ}$ & 2.50 & 2.14 & 1.60 & 2.12 & .20 & -.00 & -.14 & .69 & 1.133 & 1.007 & & 100 \\
\hline rOLLUW & WING LU & $\alpha E(s)$ & FROM C & ross s & SECTION & NEAR & COLUME & IA RIV & IER MIL & $E 47$ & & \\
\hline C3 $8 b=-1-1$ & $(2,4)$ & 1.65 & . 31 & 1.51 & .57 & -.14 & -.34 & .65 & 1.314 & 1.047 & & 100 \\
\hline $\operatorname{cod} d-=3-1$ & 2.40 & 1.66 & .62 & 1.63 & .51 & -.05 & -.29 & .75 & 1.200 & 1.007 & & 100 \\
\hline Casab--5-1* & 2.46 & 1.79 & .95 & 1.75 & .46 & -.08 & -.19 & .64 & 1.261 & 1.018 & & 100 \\
\hline $6300-\angle 0-2$ & 4.50 & 1.85 & 1.21 & 1.80 & .35 & .08 & .11 & .75 & 1.171 & .986 & & 100 \\
\hline $\operatorname{css} \theta-\angle B-2^{\circ}$ & 2.58 & 2.01 & 1.35 & 1.99 & .37 & -.07 &.,- 16 & .68 & 1.190 & 1.025 & & 100 \\
\hline FOCLUN & $1 \mathrm{NG}<0$ & $K \tilde{C}(s)$ & FROM CH & ross s & SECIION & NEAK & COLUNd & IA RIV & IER NIL & $E 42$ & & \\
\hline C382 - - v $=1$ & 4.00 & 1.32 & .18 & 1.32 & .66 & -.00 & 1.17 & 1.91 & 1.340 & .988 & 1 & 96 \\
\hline C $3 B 2=-1-1$ & 2.13 & 1.27 & .26 & 1.23 & .57 & -.06 &.- .13 & .65 & 1.302 & 1.021 & i & 99 \\
\hline $\cos \theta 2-11-1$ & 2.00 & 1.12 & .07 & 1.09 & .61 & -.05 & -.14 & .57 & 1.353 & 1.002 & 2 & 98 \\
\hline $65 a z-12-20$ & 2,13 & 1.62 & .56 & 1.37 & .47 & -.11 & -.26 & .63 & 1.260 & 1.046 & & 100 \\
\hline$c 30<-\angle 0-2$ & 2.10 & 1.22 & .08 & 1.17 & .57 & -.09 & $\because$ is & .85 & 1.258 & 1.040 & 2 & 90 \\
\hline $\cos 81=-0-10^{\circ}$ & 0.75 & 4.64 & 3.00 & 4.79 & 1.23 & .13 & 1.02 & 1.29 & 1.822 & .924 & & 32 \\
\hline Codi $=-3-1$ s & 0.21 & .0 .75 & 3.25 & 4.75 & .89 &. .30 & -.02 & .67 & 1.514 & 1.000 & & 20 \\
\hline C3ai--a-1: & 4.30 & 3.02 & 2.29 & 3.02 & .44 & -.00 & .69 & 1.33 & 1.230 & 1.001 & & 96 \\
\hline C381-11-1 & b.st & 5.36 & 2.68 & 3.64 & .47 & .21 & 1.46 & 1.85 & 1.223 & .943 & & 87 \\
\hline $23 d i=\angle 0-2 *$ & 8.71 & 4.18 & 2.94 & 4.61 & 1.32 & .30 & 1.25 & 1.22 & 1.920 & .712 & & 46 \\
\hline $\operatorname{css} \theta-\sim 0-<$ & $6.8 \mathrm{~s}$ & 3.46 & 2.76 & 3.06 & .85 & .40 & 1.55 & 1.44 & 1.s1s & .872 & & $n$ \\
\hline $23 \alpha 1-4 j-50$ & 3.33 & 3.70 & 2.72 & 3.97 & .90 & .22 & .42 & .59 & 1.568 & .058 & & So \\
\hline$-301->b-2 \theta$ & 2.40 & $2 . \pm 0$ & $<.36$ & 2.91 & .33 & .02 & .04 & .63 & $1.16 \mathrm{~s}$ & .995 & & 100 \\
\hline$c 3 s i=v 2-2^{\circ}$ & 7.72 & 3.09 & $<.4<$ & 4.53 & 1.60 & .59 & 1.03 & .66 & 2.090 & .056 & & 62 \\
\hline rOLLUW & NING & $N E(s)$ & FRon $\mathrm{CH}$ & koss s & SECIION & NEAR & COLUMB & IA RIV & IER RIL & 38 & & 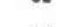 \\
\hline $\cos 300-00=10^{\circ}$ & 3.00 & 2.05 & 1.43 & 2.83 & .63 & .28 & 1.77 & 1.92 & 1.277 & .952 & & 89 \\
\hline C3000--1-1 & 3.23 & 2.53 & 1.85 & 2.54 & .41 & .02 & .00 & .76 & 1.203 & .391 & & 100 \\
\hline $638 v a-b-i$ & 2.90 & 2.19 & 1.50 & 2.20 & .44 & .02 & .03 & .61 & 1.234 & .990 & & 100 \\
\hline$c 3 s u-1 u-1$ & $.05 y$ & 2.76 & 2.09 & 2.09 & .58 & .22 & .99 & 1.17 & 1.302 & .932 & & 93 \\
\hline $\cos \theta 0-14-20^{\circ}$ & 5.10 & 2.36 & 1.07 & 2.54 & .39 & .01 & -.03 & .69 & 1.199 & .996 & & 100 \\
\hline $\cos 80=34-2^{\circ}$ & 2.83 & 2.32 & 1.89 & $2.3 \mathrm{~s}$ & .20 & .00 & .19 & .74 & 1.125 & 1.000 & & 100 \\
\hline $\operatorname{css} 0-44-20$ & 3.09 & 2.46 & 1.87 & 2.47 & .37 & .04 & .07 & .65 & 1.109 & .987 & & 100 \\
\hline $\cos 7 y=-1-1$ & 5.63 & 2.91 & 2.16 & 3.09 & .68 & .27 & 1.46 & 1.57 & 1.360 & .912 & & 88 \\
\hline $\cos 7 y--2-1$. & 6.00 & 2.77 & 2.22 & 2.03 & $.3 y$ & .14 & .05 & 1.20 & 1.171 & 1.000 & & 95 \\
\hline C379--3-10 & 8.00 & 3.30 & 2.42 & 6.06 & 1.35 & .57 & 1.42 & 1.07 & 1.600 & .672 & & 72 \\
\hline $\operatorname{css} y=-5-10$ & 7.50 & 3.27 & 2.30 & 3.09 & 1.19 & .52 & 1.43 & 1.18 & 1.485 & .801 & & 75 \\
\hline $6379-11-1$ & 3.29 & 2.56 & 1.73 & 2.53 & .44 & -.00 & -.11 & .77 & 1.227 & 1.030 & & 100 \\
\hline$c 37 y-22-2$ & 3.33 & 2.72 & 2.15 & 2.72 & .33 & -.00 & .05 & .78 & 1.159 & 1.000 & & 100 \\
\hline $6379-26-26$ & 1.55 & 3.15 & 2.36 & 3.85 & 1.22 & .57 & 1.67 & 1.13 & 1.529 & .720 & & 75 \\
\hline$c 37 y-2=-54$ & 4.46 & 3.34 & 2.50 & 3.60 & .58 & .10 & .21 & .66 & 1.305 & .360 & & 85 \\
\hline $\cos 79-42-2$ & $3.5 y$ & 2.78 & 2.22 & 2.82 & .38 & .10 & .32 & .78 & 1.184 & .992 & & 98 \\
\hline FOLLUW & NING GO & $R E(s)$ & FRU $\mathrm{C}$. & koss s & SECIION & NEAK & COLUAB & IA RIV & IER MIL & E 31 & & \\
\hline $\cos 76=-6-1$ & $3.5 y$ & 2.73 & 2.14 & 2.77 & .41 & .10 & .32 & .76 & 1.202 & .996 & & 98 \\
\hline c $370--5-1$ & 3.50 & 2.66 & 2.12 & 2.70 & .30 & .11 & .40 & .81 & 1.190 & .985 & & 99 \\
\hline $0370=-8-1$ & 3.28 & 2.50 & 2.11 & 2.62 & .33 & .11 & .36 & .76 & 1.171 & .971 & & 100 \\
\hline $1376-11-10$ & 0.25 & 2.72 & 2.25 & 2.73 & .29 & .81 & .09 & .72 & 1.145 & 1.000 & & 100 \\
\hline $6310-31-2$ & 3.50 & 2.79 & 2.00 & 2.79 & .48 & .01 & .07 & .53 & 1.204 & 1.000 & & 99 \\
\hline $3076-03-20$ & 3.59 & 2.46 & $i \neq \rightarrow 1$ & 2.64 & .67 & .3a & .69 & .70 & 1.240 & .055 & & 98 \\
\hline c3/o- $45-2$ & 2.10 & 2.46 & 2.00 & 2.69 & .32 & .16 & .35 & .73 & 1.157 & .459 & & 100 \\
\hline $237>--1-1$ & 3.5 & 2.60 & 1.50 & 2.61 & .52 & -.10 & -.22 & .83 & 1.250 & 1.067 & & 98 \\
\hline * $7>=-3-10$ & 2.83 & 1.40 & .6 & 1.64 & .66 & .25 & .41 & .65 & 1.326 & .706 & & 100 \\
\hline C37b-11-iv & 2.63 & 1.41 & .64 & 1.50 & .55 & $\therefore 6$ & .47 & .84 & 1.283 &.+36 & & 100 \\
\hline $4375-1+-2$ & 3.03 & 1.53 & .10 & 1.65 & .91 & .11 & .00 & .59 & 1.507 & .882 & 3 & 97 \\
\hline CS $/ 2-16-2^{\circ}$ & c. 44 & 1.00 & .87 & 1.89 & .68 & .13 & .15 & .53 & 1.382 & .420 & & 100 \\
\hline $037 b-54-2$ & $3.2+$ & 2.02 & .62 & 1.90 & .83 & -.03 & -.11 & .58 & 1.527 & 1.049 & & 100 \\
\hline istb- +2.20 & 2.06 & 1.31 & .13 & 1.60 & 1.03 & $.2 \mathrm{a}$ & .29 & .41 & 1.687 & .735 & 2 & 98 \\
\hline Foliow & ING GU & रE (S) & $F R C M$ & ROSS S & SELIIUN & NEAK & GOLUNE & IA RIV & VER NIL & E 27 & & \\
\hline $0370--u-10$ & 0.81 & $\rightarrow \rightarrow 0$ & 3.11 & 4.97 & 1.12 & -.01 & .01 & .65 & 1.684 & 1.000 & & 19 \\
\hline$i \$ 10-\cdots<-10$ & $y .14$ & 5.25 & 3.41 & 5.61 & 1.51 & .23 & .67 & .09 & 1.751 & .750 & & 14 \\
\hline $43700-4=10$ & 9.17 & 5.40 & S.bo & 5.81 & $1.5 \mathrm{~s}$ & .26 & .61 & .06 & 1.864 & .037 & & iI \\
\hline ¿ $578=-5-10$ & $0.7 \%$ & 4.57 & 6.94 & 5.06 & 1.60 & .20 & .76 & .73 & 2.154 & .818 & & 38 \\
\hline $6570=-6-1$ & $0.0 j$ & 3.86 & 2.67 & 4.42 & 1.32 & .46 & 1.15 & 1.03 & 1.841 & .615 & & 57 \\
\hline$i 3 / 0=0-1$ & 5.31 & 2.80 & 2.06 & 2.60 & .54 & .13 & 1.65 & 2.12 & $1.26 y$ & .758 & & 92 \\
\hline$i \leq 10-11-i$ & 3.37 & 2.60 & 2.00 & 2.60 & .40 & -.01 & .04 & .73 & 1.199 & 1.506 & & 100 \\
\hline $1370-34=2$ & 30.00 & 2.07 & 2.23 & 2.84 & .33 & .05 & -.07 & .85 & 1.165 & .989 & & 100 \\
\hline$c 37 d-40-20$ & 3.02 & 2,19 & .96 & 2.12 & .77 & -.00 & -.28 & .36 & 1.461 & 1.071 & & 100 \\
\hline $237 b=36-20$ & 2.50 & 1.59 & .59 & 1.46 & .Ss & .12 &.$<9$ & .73 & 1.207 & .969 & & 100 \\
\hline $6371--1-10$ & 6.61 & 3.18 & & 3. & .7 & .3 & 1.45 & 1.51 & 1.307 & .9 & & 83 \\
\hline $6371--2-10$ & 0.01 & 3.08 & 2.31 & 3.53 & .93 & .49 & 1.16 & .98 & 1.411 & .795 & & 79 \\
\hline $2377=-3-1$ & 0.74 & 2.93 & 2.22 & 2.96 & .61 & .67 & .11 & .86 & 1.211 & .317 & & 90 \\
\hline $0377 \cdots-1$ & 3.87 & 2.09 & 2.25 & 2.92 & .44 & .00 & .61 & .07 & 1.226 & .975 & & 96 \\
\hline cost7-15-10 & 4.33 & .0 .73 & 2.94 & 5.32 & 1.98 & .30 & .71 & .61 & 2.554 & .751 & & 37 \\
\hline$\angle 3 / 7-\angle 7-\angle 0$ & 4.14 & 3. vo & 2.31 & 3.11 & .51 & $.0 y$ & .91 & 1.40 & 1.252 &.+83 & & 92 \\
\hline csit-ol-2* & 5.02 & 3.02 & 2.19 & 3.24 & .76 & .30 & .76 & .85 & 1.342 & .924 & & 86 \\
\hline
\end{tabular}

See footnotes at end of table. 

Appendix II.--Particle-sine atatiatica of selected aegments of cores from the Columbia River eatuary. Statiatics
computed according to Inman (1952) and Trank (1932)---Continued

\begin{tabular}{|c|c|c|c|c|c|c|c|c|c|c|c|c|c|c|}
\hline \multirow[b]{2}{*}{ SAMPLE HO } & \multirow{2}{*}{\multicolumn{3}{|c|}{ 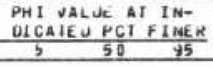 }} & \multicolumn{5}{|c|}{ INMAN VALLES } & \multicolumn{2}{|c|}{$\begin{array}{l}\text { TRASK } \\
\text { YAL UES }\end{array}$} & & PERCE & NI & \\
\hline & & & & MEAN & SORT & ALPHI & ALPH2 & BEIA & SURT & SKEM & GRAVEL & SAND & SILT & GLAY \\
\hline FULA & ING & & . & CROSS & 3ection & we & $\mathrm{COL}$ & & & & & & & \\
\hline $\cos 69--1-10$ & 9.44 &. .98 & 2.29 & 5.32 & 1.94 & .10 & .47 & .00 & 2.141 & .956 & & 27 & 62 & 11 \\
\hline C369--4-1e & 8.85 & 3.94 & 2.10 & 4.69 & 1.07 & .40 & .02 & .01 & 2.274 & .536 & & 52 & 40 & 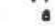 \\
\hline$c 369=-2-1$ & 0.30 & 3.17 & 2.00 & 3.21 & .75 & .00 & 1.40 & 2.04 & 1.373 & 1.002 & & 85 & 12 & 3 \\
\hline $\cos 69-11-1$ & 3.44 & 2.46 & 1.35 & 2.45 & .62 & -.00 & -.10 & .69 & 1.327 & .386 & & 100 & & \\
\hline$-369-18-2$ & 3.64 & 2.30 & 1.10 & 2.34 & .67 & .05 & .10 & .90 & 1.337 & .965 & & 97 & 3. & \\
\hline$i s b y-\angle z-2$ & 4.00 & 2.94 & 2.11 & 2.97 & .56 & .05 & .20 & .60 & 1.303 & .386 & & 95 & 5. & \\
\hline C369-34-20 & 5.00 & 3.43 & 2.41 & 3.75 & .90 & .33 & .59 & .63 & 1.501 & .770 & & 60 & $32+$ & \\
\hline $\csc \theta-40-2 \theta$ & 4.90 & 3.04 & 2.12 & 3.16 & .69 & .17 & .36 & .63 & 1.391 & .906 & & 67 & $33+$ & \\
\hline C3/3--1-1 & 7.40 & 3.14 & 2.73 & $4.2 \mathrm{~J}$ & 1.14 & .44 & 1.20 & 1.00 & 1.600 & .676 & & 60 & 36 & 4 \\
\hline$-5 / 3--5-1$ & 3.60 & 3.31 & 2.66 & 3.42 & .52 & .22 & 1.67 & 1.93 & 1.243 & .946 & & 86 & 12 & 2 \\
\hline C373 $--7-1$ & 0.67 & 3.12 & 2.58 & 3.11 & .31 & -.03 & .03 & .76 & 1.154 & 1.007 & & 99 & $1+$ & \\
\hline $2373-10-10$ & 4.75 & 3.43 & 2.10 & 3.62 & .57 & .33 & .57 & .71 & 1.296 & .056 & & 70 & $22+$ & \\
\hline C.373-24-2 & 5.93 & 3.28 & 2.64 & 3.31 & .31 & .00 & .12 & 1.02 & 1.141 & 1.000 & & 96 & $\omega$ & \\
\hline FOLLOM & NING CO & DKE (s) & FROM & CROSS & SECIION & NEAR & GOL UM & UIA RIV & VEK MIL & LE 18 & & & & \\
\hline $\cos 10=-1-1$ & 2.31 & 1.29 & .08 & 1.30 & .72 & -.13 & -.27 & .53 & 1.410 & 1.085 & 2 & 98 & & \\
\hline $0370--4-10$ & 2.15 & 1.03 & -1.29 & .97 & .78 & -.00 & -.78 & 1.20 & 1.454 & 1.030 & 7 & 93 & & \\
\hline c $370-10-2^{\circ}$ & 2.22 & 1.42 & .60 & 1.43 & .51 & .01 & -.04 & .60 & 1.260 & .997 & & 100 & & \\
\hline $\cos 70-66-2^{\circ}$ & 2.85 & 2.19 & .36 & 2.00 & .59 & -.31 & -.99 & 1.12 & 1.263 & 1.094 & 1 & 99 & & \\
\hline $\mathrm{C} 310-34-2$ & 2.91 & 1.92 & -2.35 & .06 & 1.56 & -.68 & -1.05 & .69 & 1.556 & 1.488 & 15 & 85 & & \\
\hline $6308--3-1$ & 0.00 & 3.53 & 2.61 & 4.23 & 1.32 & .53 & 1.56 & 1.06 & 1.770 & .592 & & 65 & 30 & 5 \\
\hline $\cos 08=-4-1$ & 3.74 & 2.90 & 2.31 & 2.99 & .40 & .02 & .11 & .79 & 1.205 & .994 & & 98 & 2, & \\
\hline $6360--5-10$ & 4.00 & 3.09 & 2.43 & 3.12 & .44 & .07 & .29 & .80 & 1.222 & .982 & & 95 & $5+$ & \\
\hline CSOSO-11-1" & 6.03 & 3.14 & 2.39 & 3.46 & .76 & .41 & 1.37 & 1.32 & 1.250 & .987 & & 82 & 16 & 2 \\
\hline $\cos 0-16-24$ & 0.30 & 3.57 & 2.50 & 6.32 & 1.66 & .52 & 1.28 & 1.01 & 1.911 & .562 & & 63 & 31 & 6 \\
\hline $1300-32-2 *$ & 3.76 & 3.08 & 2.43 & 3.06 & . .31 & .065 & -.03 & .70 & 1.189 & 1.016 & & 99 & 10 & \\
\hline C360-36-20 & 5.35 & 3.81 & 2.70 & 3.89 & .86 & .09 & .25 & .54 & 1.500 & .947 & & 58 & $42+$ & \\
\hline isos $-42-2$. & 4.93 & 3.42 & 2.56 & 3.00 & .71 & .26 & .65 & .68 & 1.381 & .855 & & 75 & 25 . & \\
\hline rOLLOW & $\triangle N A G<0$ & Jex (s) & From & CROSS & SECIION & NEAR & Colume & BIA RIV & VER MIL & LE 14 & & 13 & $28 \mathrm{~V}$ & \\
\hline C $371=-2-14$ & 6.05 & 2.90 & 1.61 & 4.24 & 2.33 & .57 & 1.00 & .56 & 3.253 & .289 & & 37 & 35 & o \\
\hline $23 r i=-1-1$ & 2.44 & 2.01 & 1.26 & 1.94 & .33 & $-.2 i$ & -.68 & .79 & 1.163 & 1.065 & & 100 & & \\
\hline c371-16-2 & Z., $v_{6}$ & 1.49 & 1.24 & 1.98 & .36 & -.03 & 1.83 & 2.81 & 1.181 & 1.010 & & 95 & $5+$ & \\
\hline $0371-26-24$ & 14.03 & 2.20 & .36 & 5.24 & 3.97 & .77 & 1.25 & .72 & 2.276 & .429 & 1 & 76 & $25+$ & \\
\hline $637 i-40-2$ & ..ov & 1.91 & 1.00 & 1.87 & .48 & -.08 & 1.22 & 2,10 & 1.251 & 1.028 & & 95 & 3 & 2 \\
\hline$c 371-46-20^{\circ}$ & y.58 & 2.43 & 1.63 & 6.11 & 2.13 & .79 & 1.49 & .86 & $2.36 \mathrm{~d}$ & .274 & & 31 & 20 & 9 \\
\hline$i 27 i=-4-2$ & 0.55 & 2.36 & 1.63 & 2.47 & .47 & .23 & 3.66 & 4.20 & $1.22 \mathrm{~d}$ & .931 & & 90 & 7 & 3 \\
\hline$c 307=0-1$ & 7.39 & 2.24 & 1.32 & 2.62 & .90 & .43 & 2.35 & 2.36 & 1.313 & .923 & 1 & $\$ 6$ & 9 & 6 \\
\hline c307--1-i & $2.5 j$ & 1.99 & 1.00 & 1.06 & .42 & -.25 & -.57 & .80 & 1.213 & 1.095 & & 100 & & \\
\hline csbl- $=-a-1$. & 5.05 & 2.08 & 1.16 & 2.04 & .47 & -.10 & 3.02 & 3.99 & 1.263 & 1.061 & & 92 & at & \\
\hline c367-11-20 & 2.40 & 1.89 & .93 & 1.06 & .41 & -.12 &.$- .4 a$ & .88 & 1.205 & 1.028 & & 100 & . & \\
\hline C367-23-20 & 2.40 & 1.79 & .66 & 1.70 & .51 & -.1 в &.- .45 & .75 & 1.240 & 1.030 & & 99 & $1+$ & \\
\hline $6367-05-2$ & 4.00 & 1.74 & 1.04 & 1.78 & .49 & .09 & 1.61 & 2.03 & 1.260 & .977 & & 95 & 3 & 2 \\
\hline $636 /-37-2$ & 7.23 & 2.16 & 1.13 & 2.31 & .63 & .23 & 3.19 & 3.02 & 1.245 & 1.012 & & 87 & 9 & 4 \\
\hline C367 $1-0-1)^{*}$ & $y .00$ & 2.73 & 1.69 & 4.10 & 2.10 & .65 & 1.26 & .75 & 2.669 & .298 & & 65 & 27 & - \\
\hline $03671-2-1$ & 2.50 & 1.92 & .00 & 1.80 & .0 .5 & -.21 & -.60 & .07 & 1.227 & 1.063 & & 100 & & \\
\hline c367111-2. & 6.56 & 1.97 & .06 & 1.86 & .66 & -.25 & -.58 & .85 & 1.230 & 1.094 & & 100 & & \\
\hline $6306=-0-1=$ & 8.32 & 4.08 & 2.24 & 4.24 & 1.78 & .09 & .67 & .71 & 2.536 & 1.055 & & so & 64 & 6 \\
\hline $1300=$ & 0.63 & 5.00 & 3.29 & 5.07 & 1.11 & .06 & .07 & 1.41 & 1.632 & 1.0000 & & in & 76 & 7 \\
\hline c $366--2-1$. & 0.00 & 5.00 & 3.00 & 5.30 & 1.35 & .16 & .61 & 1.15 & 1.701 & 1.000 & & in & 75 & : \\
\hline c306 $=-3-i$ & $7.6 \mathrm{~J}$ & 4.75 & 3.41 & 4.00 & .96 & .05 & .70 & 1.17 & 1.609 & 1.000 & & 23 & 73 & 4 \\
\hline c3ou--5-1 & & & & & & & & & & & & 2 & $9 a+$ & \\
\hline C366--9-26 & 6,70 & 5.26 & 3.72 & 5.24 & .92 & -.00 & -.00 & .65 & 1.541 & 1.000 & & 9 & $91+$ & \\
\hline $\cos 22=0-1$ & 4.55 & 2.52 & 2.03 & 2.61 & .39 & .23 & 1.95 & 2.21 & 1.202 & .923 & & 94 & 4 & 2 \\
\hline C372-11-10 & 3.60 & 2.59 & 2.12 & 2.60 & .30 & .02 & .04 & .64 & 1.150 & .495 & & 100 & & \\
\hline CS $7<-\angle 2-2$ & 3.13 & 2.46 & 1.90 & 2.50 & .35 & .06 & .09 & .77 & 1.176 & .902 & & 100 & & \\
\hline C372-j4-2 & 3.00 & 2.46 & 2.00 & 2.52 & .29 & .13 & .27 & .70 & 1.146 &.+66 & & 100 & & \\
\hline $\operatorname{cst} 20-58-\varepsilon^{\circ}$ & $7.6 \Rightarrow$ & 2.66 & 2.04 & 3.02 & .76 & .48 & 2.91 & 2.72 & 1.243 & .959 & & 85 & 15. & \\
\hline$c j 3<-52-2$ & 3.60 & 2.92 & 2.26 & 2.91 & .41 & -.04 & .01 & .66 & 1.212 & 1.015 & & 99 & 10 & \\
\hline FOLLON & WING iv & $\lambda \vec{e}$ (s) & FROH & CKOSS & SECIION & NEAR & COLUnt & BIA KIV & IER MIL & $L E 6$ & & & & \\
\hline csose- $1-10$ & 16.35 & 3.68 & 1.70 & 5.44 & 3.01 & -.08 & .11 & .63 & 3.076 & .766 & & 21 & 5y & 20 \\
\hline $\cos \theta=-3-1$ & 11.60 & 7.07 & 1.74 & 7.15 & 2.71 & .03 & -.13 & .02 & 3.596 & .953 & & 12 & $5 i$ & 37 \\
\hline 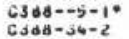 & 10.06 & 5.70 & 3.91 & 6.58 & 1.48 & .45 & .85 & .76 & 2.334 & .509 & & $\begin{array}{l}6 \\
2\end{array}$ & 74. & 20 \\
\hline issog--1-1 & 2.40 & $<.14$ & 1.71 & 2.13 & .22 & -.07 & -.23 & .75 & 1.100 & 1.000 & & 100 & & \\
\hline $6389-13-23$ & 10.00 & 2.35 & 1.66 & 7.96 & 6.04 & .93 & .91 & .02 & 0.936 & .019 & & 70 & $30+$ & \\
\hline $6309-2 y-2$ & 2.50 & 2.15 & 1.71 & 2.13 & .23 & -.00 & -.18 & .73 & 1.106 & 1.000 & & 100 & & \\
\hline Fúluar & NING CO & KE (S) & FROM & cross & StCIIION & NEAR & COLUMO & SIA RIV & EER AIL & $L E 2$ & & & & \\
\hline caso $7-\cdots-1^{\circ}$ & 9.32 & ..37 & 2.06 & 4.66 & 2.07 & .04 & .64 & .76 & 2.759 & 1.547 & & 42 & 69 & 9 \\
\hline $6387=-3-1$ & 2.14 & 2. & 1.06 & 2.34 & .27 & .03 & -.07 & .04 & 1.129 & 1.000 & & 100 & & \\
\hline $6307--5-1^{\circ}$ & 2.67 & 2.21 & 1.66 & 2.20 & .29 & -.04 & -.15 & .72 & 1.141 & 1.000 & & 160 & & \\
\hline $\cos 8=14-2$ & 6.00 & 2.57 & 1.70 & 2.81 & .69 & .34 & .40 & .66 & 1.395 & .003 & 1 & 94 & 5. & \\
\hline C387-04-C. & 2.08 & 2.31 & 1.93 & $2.3 i$ & .23 & .00 & & .66 & 1.113 & 1.000 & & 100 & & \\
\hline cis $\Delta>1+0-1 *$ & 9.63 & 4.63 & $<.35$ & 4.86 & 1.86 & .12 & .74 & .96 & 2.164 & 1.020 & & 35 & 55 & 10 \\
\hline $\operatorname{css} 71-3-10$ & 2.67 & 2.26 & 1.74 & 2.24 & .27 & -.21 &.- .13 & .75 & 1.130 & 1.000 & & 100 & & \\
\hline i387111-i* & 2.63 & 2.21 & 1.66 & 2.20 & .20 & -.05 & -.20 & .77 & 1.136 & 1.000 & & 100 & & \\
\hline
\end{tabular}

- higher onver statisitcs for this sample mat be in ekrur

; SILI PlUis Llar

i all STAIISILCS FOR IHIS SAMPLE maY ge IN ERRor 


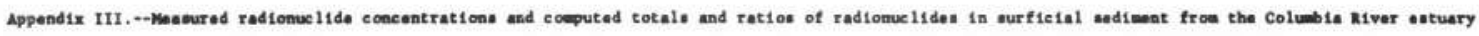
[Lese-then values or totals includine lese-thes values indicated by *, Questionable values indicated by A]

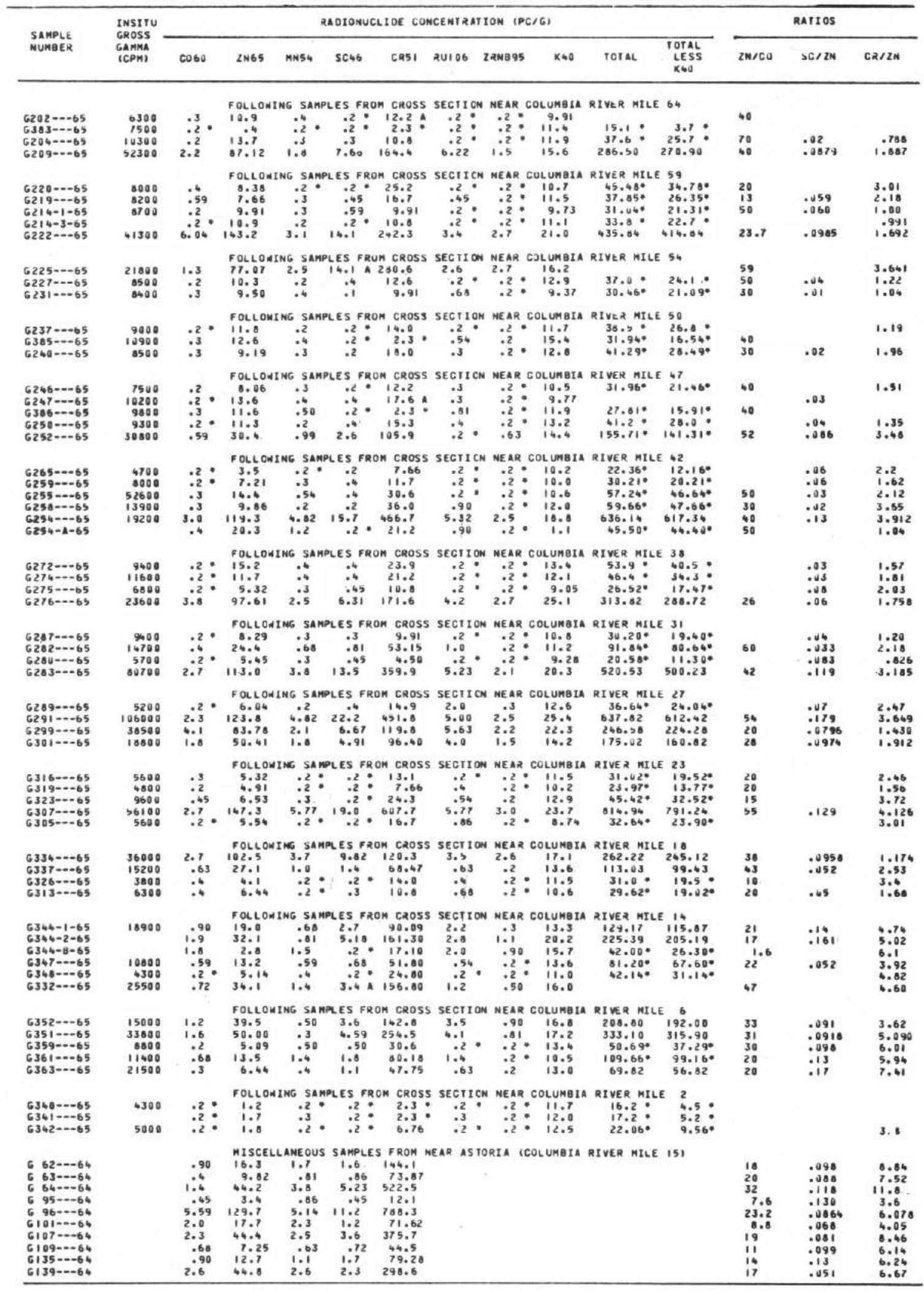


Appendix IV..-Meanured radionuclide concentratione and conputed totels and ratios of radionuclides in selected seguents of cores from the Columbia River

[Lesp-than values or total, Including less-than values indicated by $\star$. Questionable values indieated by A]

\begin{tabular}{|c|c|c|c|c|c|c|c|c|c|c|c|c|c|c|}
\hline \multirow{2}{*}{$\begin{array}{l}\text { SAMPLE } \\
\text { NUMBER }\end{array}$} & \multirow{2}{*}{$\begin{array}{l}\text { INSI TU } \\
\text { GROSS } \\
\text { GAMMA } \\
\text { ICPMI }\end{array}$} & \multicolumn{10}{|c|}{ RADIOAULLLDE CONCENTRAT ION $(P C / G)$} & \multicolumn{3}{|c|}{ RATIOS } \\
\hline & & cosu & $2 N 65$ & MN54 & $5 \mathrm{~S}_{4} 6$ & CR51 & RU106 & ZRNB95 & $k 40$ & TOTAL & $\begin{array}{l}\text { TOIAL } \\
\text { LESS } \\
\text { K } 40\end{array}$ & $2 \mathrm{~N} / \mathrm{CO}$ & $56 / 2 \mathrm{~N}$ & $\mathrm{CR} / \mathrm{Zit}$ \\
\hline
\end{tabular}

FOLLOMING COREISI FROM CROSS SECIICN NEAR COLUMBIA RIVER MILE G4

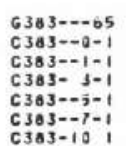

c303-10,

$6304=-65$

C $304=0-1$

C $384=-3-1$

C3 $84--5-1$

C $384-34-2$

C $384-40-2$

$6385-2-65$

C. $3850-1-1$
cos

c $385=-3-1$

C $305=-5-1$

C $385-10-1$

C 385-11-1
C 385-1?

C $385-1$ ? -1

C $305-34-2$

C385-4a-2

$6386---6 b$

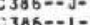

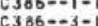

C $386 \ldots-5-1$

C386-2.

c30b-11-1

C386-22-2

C386-34-2

C $386-56-2$

$6382 \cdots 65$

C)

c $382=2-1$

C385-2-3-1

C382-24-

c. $382=-5-1$

C $382=1-1$

C $382=-8-1$

C $382-11-1$
C $382-20-2$

$6381=-65$

C $381=0.1$

c $381=-3-1$

C $381 . .5-5-1$

C $381=-8-1$

C381-11-1

C) $381-14-1$
C $381-18-2$

c $381=20-2$

C $381-24-2$

C $381-30-2$
C $381-32-2$

C $381-32-2$

C $381-60-2$

C $381-63-2$
C381-50-2

C3 $31-62-2$

$6380=-265$

C380-0u-1

C $300=-1-1$

C $3800-25-1$
C $3800-2-1$

C $380-10-1$

C3 $30-11-1$

C380-22-2

$6380-364-2$
$6380-44-2$

$6379 \cdots 65$

C $379=-0-1$

c $3792--2-1$
$6379-1-1$

C $379--3-1$

C $3790-2-1$

c $379=-7=1$

C $379=11=1$

1500

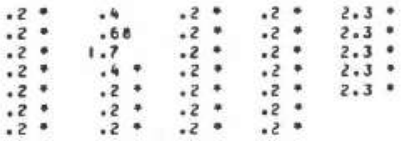

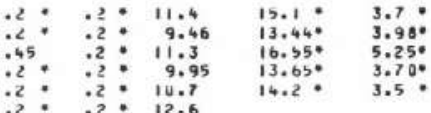

FOLLONING CORE (S) FRUN CROSS SECTICN NEAR COLUMBIA RIVER MILL 54

7900

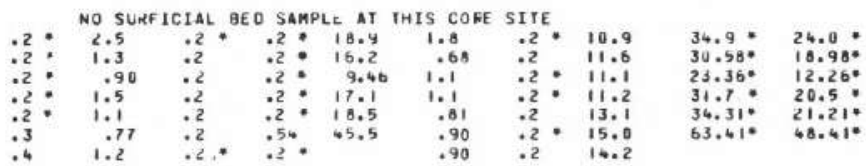

FOLLONING CUREIS) FROM CROSS SECTICN NEAR COLUMBIA RIVEQ MILE SO

14900

$\begin{array}{llll}.3 & 12.6 & .4 & .2 \\ .4 & 25.4 & : 45 & .4 \\ .59 & 12.3 & .2 & .2 \\ .2 & 13.3 & .3 & .2 \\ .2 & 12.8 & .4 & .2 \\ .2 . & 12.9 & .3 & .2 \\ .63 & 12.5 & .4 & .2 \\ .5 & 9.46 & .2 . & .2 \\ .2 . & 2.2 & .2 . & .2 \\ .2 & 2.9 & .2 & .2 \\ .2 . & 1.4 & .2 . & .2\end{array}$

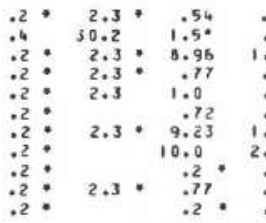

$\begin{array}{ll}.2 & 15.4 \\ .95 & 15.9 \\ 1.3 & 21.8 \\ .3 & 14.9 \\ .2 & 14.8 \\ .59 & 14.2 \\ 1.2 & 20.4 \\ 2.5 & 17.2 \\ .81 & 14.8 \\ .2 & 14.9\end{array}$

$31.96 *$
75.20
$47.65 *$
32.27
31.9 .

$46.86 *$

$16.54^{\circ}$
$59.30^{\circ}$

$25.85 *$
17.370

$21.67 \% \quad 6.770$

FOLLCAING CORE (S) FROM CROSS SECIICN NEAR COLUMAIA RIVER MILE T?

9000
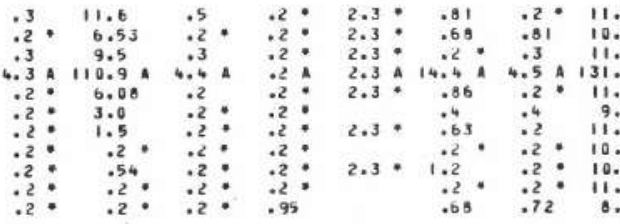

$.81 \quad 10.6$

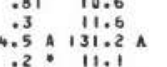

.2 - 11.1

.2 .11 .1

$.2: 10.6$
$.2: 10.5$
$.2: 11.9$

$21.32^{\circ} \quad 10.920$

$21.14 * 10.04 *$

$16.33^{\circ} 5.23^{\circ}$

$15.340 \quad 6.860$

FOLLOAING CORE (S) FROH CROSS SECIICN NEAR COLUMBIA RIVER MILE $\$ 2$

5500

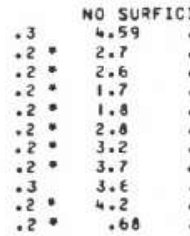

$$
\begin{aligned}
& \begin{array}{l}
.2: 0.2: 25.7: \\
.2: .2: 9.46
\end{array} \\
& \text { CORE SITE }
\end{aligned}
$$

$.77 .2: 8.13$

$.2 \div 2.3 * 90 \quad .2 \div 90.51$

$3.02: 01, .2 \div 10.4$

$.2+.2 \div 8.56$

$\begin{array}{lll}.2 & .2 & 10.9 \\ .4 & .2 & 10.2\end{array}$

$.45: .2 \div 10.2$

$.2: .2: 8.11$

106000

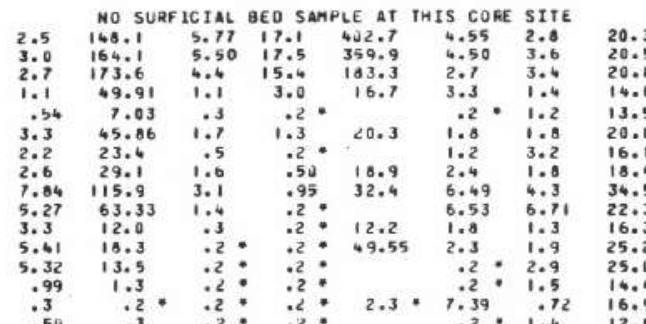

20.3
20.5
20.8
14.0
13.5
20.0
16.1
18.4
34.5
22.3
16.3
25.2
25.8
16.4
16.9
12.8

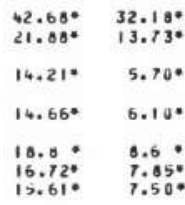

FOLLCNING COREISI FROM CROSS SECIICN NEAR COLUMBIA RIVER MILE 3 BO

10500

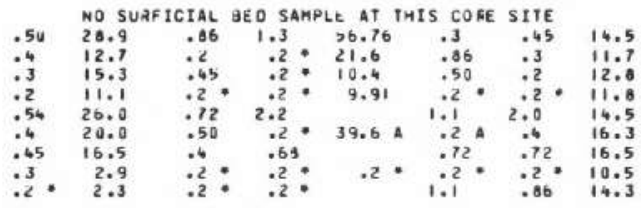

$603.82 \quad 583.52$

$\begin{array}{ll}578.60 & 558.10 \\ 406.3 & 385.5 \\ 90.51 & 76.51\end{array}$

$96.06 \quad 76.46$

$\begin{array}{rr}75.30 & 56.90 \\ 205.48 & 170.98\end{array}$

$103.06=97.860$

$26.21 * 11.31 *$

20

5.60
5.5

40

30

.17
.08
.08 $\quad .97$

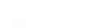

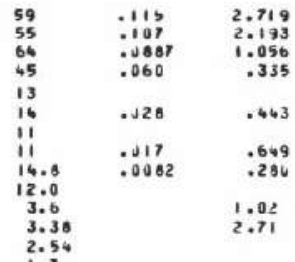

$\begin{array}{ll}103.57 & 89.07 \\ 47.96 & 36.760\end{array}$ $\begin{array}{ll}47.960 & 36.260 \\ 33.15 * & 27.35 *\end{array}$

$14.7 . \quad 4.2 \cdot \begin{array}{ll}50 & .083 \\ 37 & .441 \\ 10 & \end{array}$

$63.1: 47.5 \cdot$

$28.64^{\circ}$
$31.08 *$$\quad 20.54^{\circ}$

$56.43^{*}$

$20.10^{\circ}$

$23.61 *$

$17.51^{\circ}$

$36.28 \% 17.300$

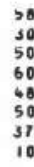

.045

1.90
1.70

.684
.843

34
13
30
45
10
16
15
2

.037

.030 

entuary--Continued

[Lees-than values or total. Including less-than values indicated by *. Queationable values indicated by A]

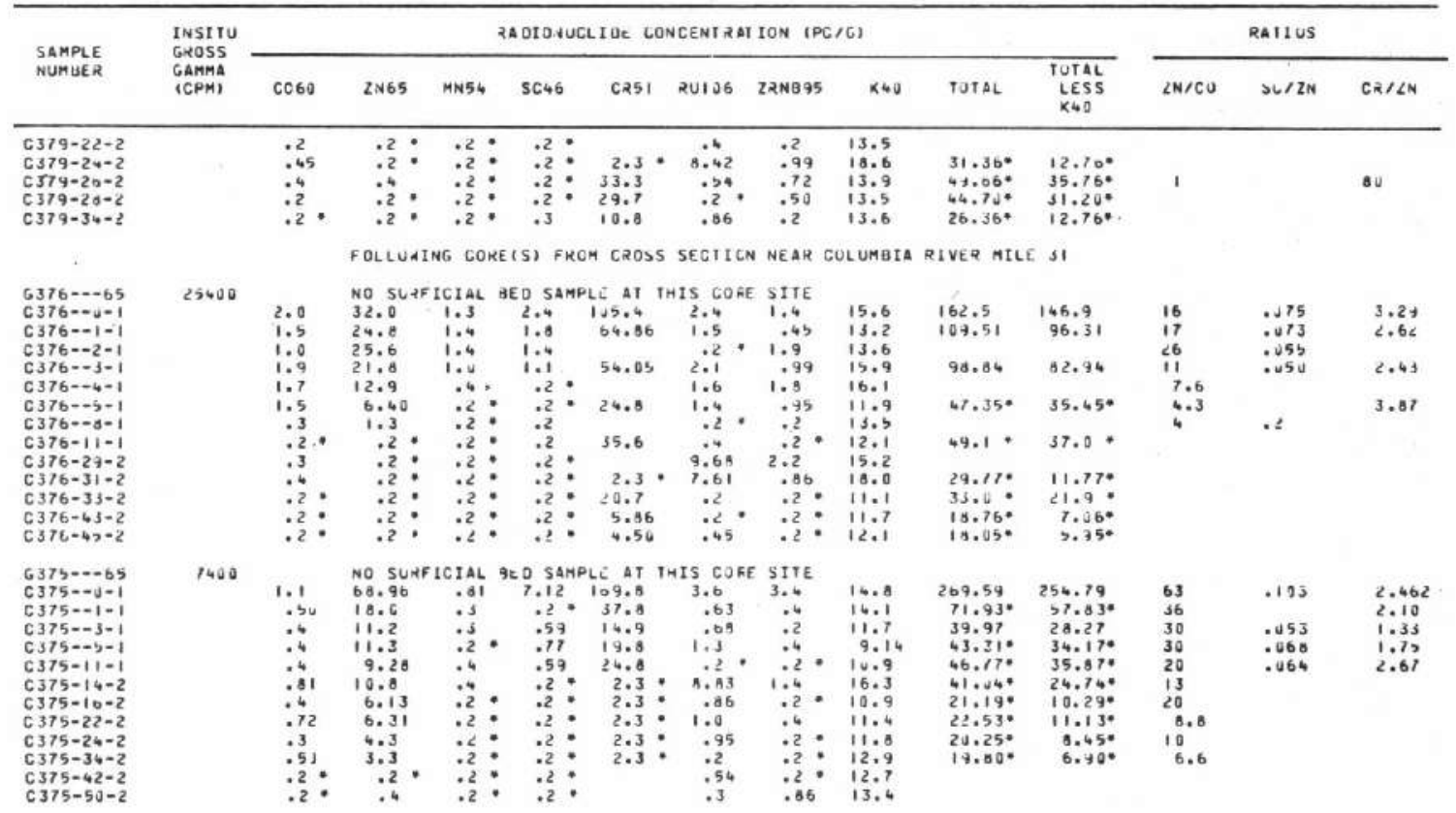

FOLLCAING COREISI FROM CROSS SECIICN NEAR COLUMBIA RIVER MILF ZT

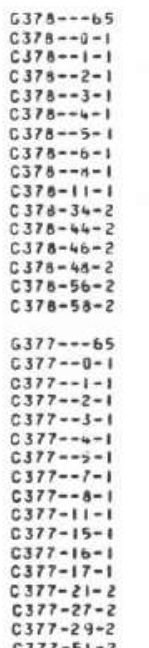

130000
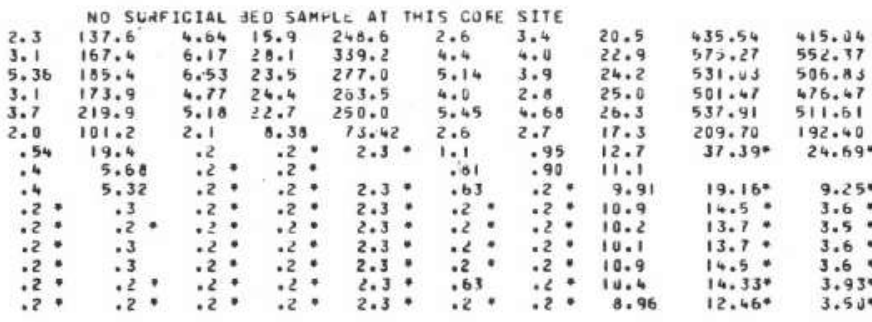

98900
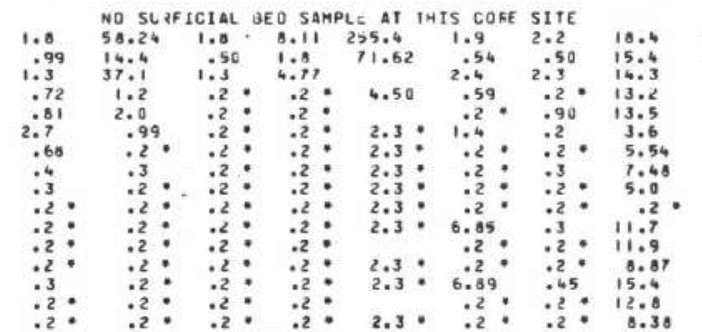

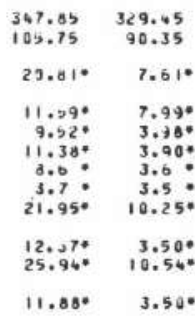

FOLLCNING COAE ISI FROM CROSS SECTICN NEAR COL UMBIA RIVER NILE 23

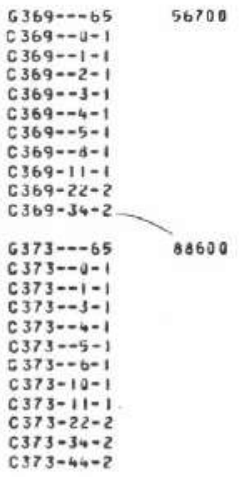

$6 \quad b \cdots b s$

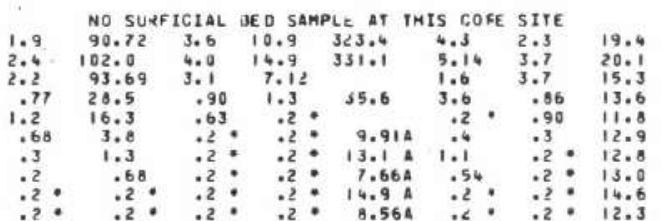

$\begin{array}{ll}456.52 & 437.12 \\ 483.34 & 663.24\end{array}$

$85.13 \quad 71.53$

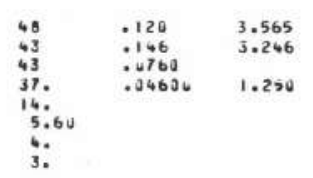

\section{no slzfictal beo samrle at thts cofe stie}

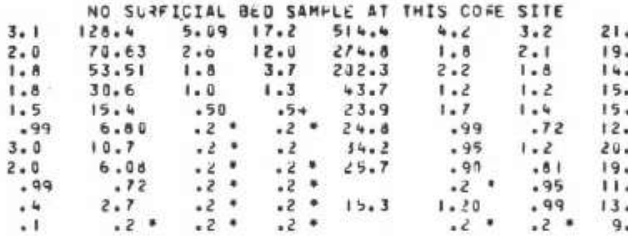

21.9
19.7
14.3
15.5 15.3
15.5
12.7 NO SURFICIAL BEO SAMPLE AT THIS COFE SITE 


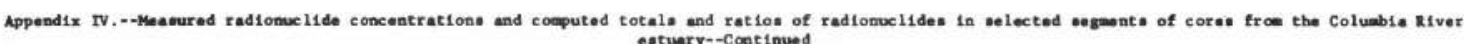

[Lese-then values or totals including less-than values indicated by *, Queationable values indicated by A]

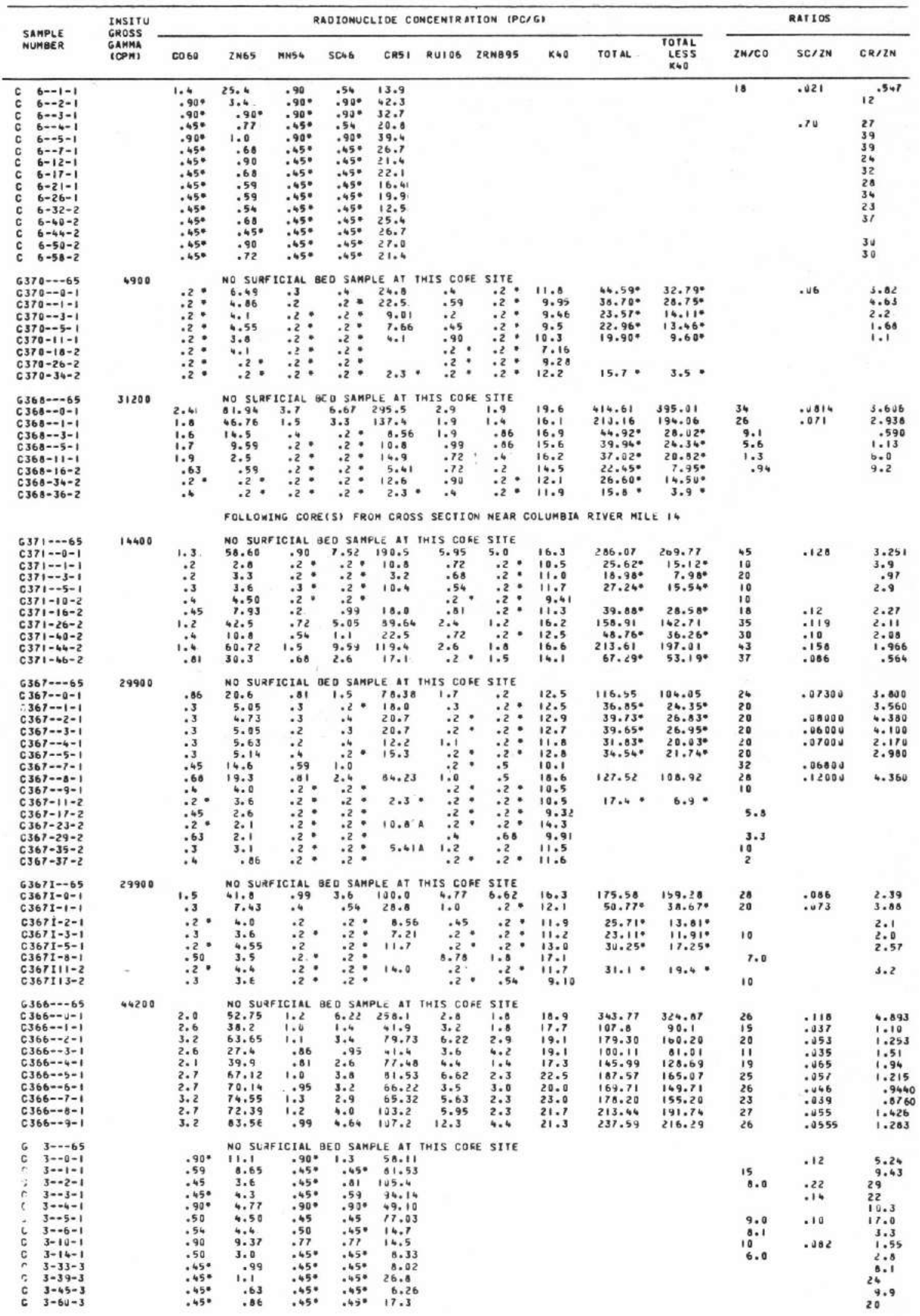




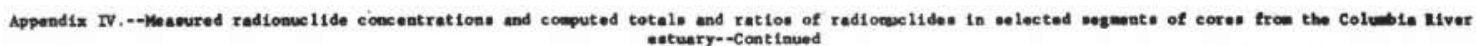

[Lese-then values or totale including lass-than values indicated by *. Questionable valuas indicated by A]

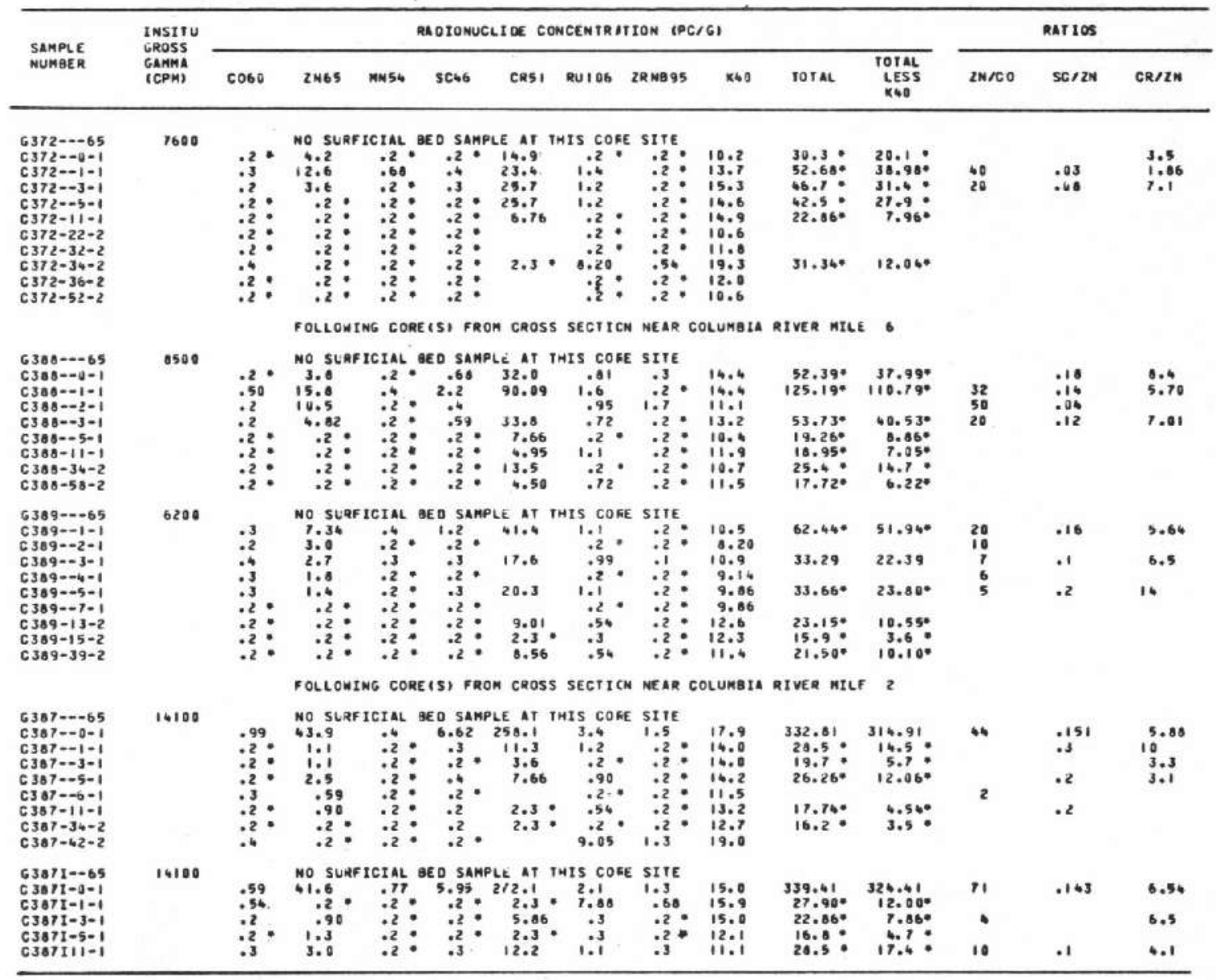




\section{APPEND LX V}

DETERMINATION OF THE AMOUNT OF RADIONUCLIDES PER UNIT AREA

BELOW THE BED SURFACE

Data on the vertical variation of radionuclides and sediment texture can be used to determine the distribution and total amount of a radionuclide or radionuclides throughout the entire column of bed sediment. The computation is carrled out on the basis of a unit area and is made from

$$
A_{d}=K \sum_{i=1}^{n} \gamma_{i} R_{i} h_{i}
$$

where

A is the amount of a radionuclide (or radionuclides) per unit area between the bed surface and any depth, d, below the surface;

$\gamma_{i} \quad$ is the speciflc weight of sediment, in place, in the ith depth increment below the bed surface, expressed in the units of weight per unit volume;

$R_{i}$ is the concentration of the radionuclide (or radionuclides) in the ith depth increment below the bed surface, expressed in the units of amount per unit weight;

$h_{i}$ is the height of the ith depth increment below the surface;

$n$ is the number of depth increments between the bed surface and depth, $d$, and

K is an appropriate units-conversion constant. 
In the computations, values of $R_{i}$ were taken from appendix IV and values of $Y_{i}$ were determined from figure $V a$ by using median values given in appendix II. Figure Va, which is a relation between particle size and specific welght, was defined by Hembree and others (1952) from reservoir deposits. Data obtained by the U.S. Army Corps of Engineers (1960, p1s. 307-308) from estuary samples are plotted in the figure for comparison. Although the points scatter considerably, the curve appears to represent the average relationship reasonably well. For depth increments for which $R_{i}$ and $\gamma_{i}$ were not defined, values were determined by proration between known values.

In most cores, the total depth to which radionuclides extended was not prectsely defined by the radionuclide analyses. In order to estimate the total depth and the amount of radionuclides in the whole sediment column, values of $A_{d}$ and $d$ were plotted by increments to define the attenuation of radionuclide concentrations with depth; the amount and total depth were taken as the values of $A_{d}$ and $d$, respectively, where the slope of the curve, $\mathrm{dA}_{\mathrm{d}} / \mathrm{dd}$, equaled zero. 


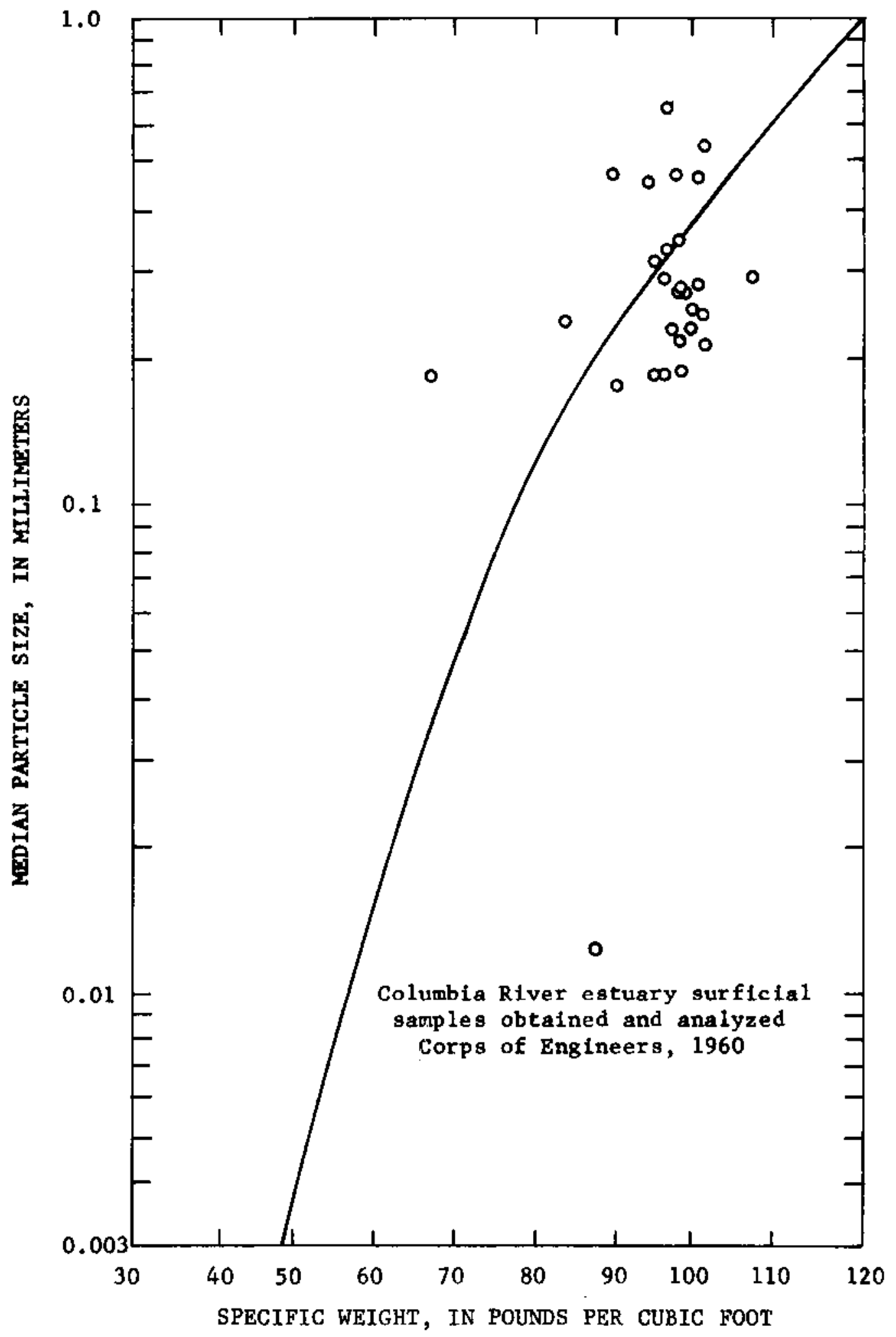

Figure Va.--Relation between specific weight of sediment in place and median particle size (from Hembree and others, 1952). 


\section{APPENDIX VI}

EXPLANATION OF VARIABLES USED IN THE COMPUTATION OF THE FRACTION OF FINE SEDIMENT RETAINED IN THE ESTUARY

Radionuclide and sediment transport data presented by Haushild and others (1966) and Foster (1964) for the Columbia River at Vancouver together with other data can be used to obtain values of the variables and constants required to compute $P$, the fraction of fine sediment retained in the estuary, from equation 5. Transport-related variables are evaluated as follows: Equating the total discharge of ${ }^{65} \mathrm{Zn}$ associated with sediment to its component parts gives

$$
\begin{array}{r}
\text { If } \frac{\mathrm{C}_{\mathrm{f}} \mathrm{r}_{\mathrm{p}}=\mathrm{p}_{\mathrm{f}} \mathrm{Q}_{\mathrm{s}} \mathrm{C}_{\mathrm{f}}+\mathrm{p}_{\mathrm{c}} \mathrm{Q}_{\mathrm{s}} \mathrm{C}_{\mathrm{c}}}{\mathrm{C}_{\mathrm{c}}}=\mathrm{b} \text {, then } \mathrm{c}_{\mathrm{c}}=\frac{\mathrm{R}_{\mathrm{n}} \mathrm{r}_{\mathrm{p}}}{\mathrm{Q}_{\mathrm{g}}\left(\mathrm{p}_{\mathrm{c}}+\mathrm{b} \mathrm{p}_{\mathrm{f}}\right)}
\end{array}
$$

where

$C_{f}$ and $c_{c}$ are the concentrations of ${ }^{65} \mathrm{Zn}$ assoctated

with fine and coarse sediment, respectively;

$\mathrm{R}_{\mathrm{n}} \quad$ is the total discharge of ${ }^{65} \mathrm{Zn}$;

$r_{s}$ and $r_{p}$ are the fractions of the discharge of ${ }^{65} \mathrm{Zn}$

that are transported in solution and in association with the sediment, respectively;

$Q_{\mathrm{S}} \quad$ is the total sediment discharge; and

$p_{f}$ and $p_{c}$ are the fractions of the total sediment discharge, by weight, that are fine and coarse sediment, respectively. 
Thus, the discharge of ${ }^{65} \mathrm{Zn}$ associated with the coarse sediment, $C_{c} Q_{c}$, is

$$
C_{c} Q_{c}=\frac{P_{c} Q_{s} R_{n} r_{p}}{Q_{s}\left(P_{c}+b P_{f}\right)}=\frac{P_{c} R_{n} r_{p}}{P_{c}+b p_{f}} .
$$

Similarly, the discharge of the ${ }^{65} \mathrm{Zn}$ associated with the fine sediment, $C_{f} Q_{f}$, is

$$
C_{f} Q_{f}=\frac{p_{f} b R_{n} r_{p}}{p_{c}+b p_{f}} .
$$

Also, (see definitions on p. 99)

$$
R_{S}=\frac{\left(C_{s} Q_{W}\right)_{I}}{\left(C_{f} Q_{f}\right)_{I}}=\frac{R_{n} r_{s}}{\frac{P_{f} b R_{n} r_{p}}{P_{c}+b P_{f}}}=\frac{r_{s}\left(p_{c}+b P_{f}\right)}{r_{p} b P_{f}}
$$

and

$$
R_{c}=\frac{\left(C_{c} Q_{c}\right)_{I}}{\left(C_{f} Q_{f}\right)_{I}}=\frac{\frac{P_{c} R_{n}{ }_{p}}{P_{c}+b p_{f}}}{\frac{P_{f} b R_{n}{ }^{r}}{P_{c}+b p_{f}}}=\frac{P_{c}}{b P_{f}} .
$$

The value of " $b$ " $c$ an be approximated from several different kinds of data by representing the ${ }^{65} \mathrm{Zn}$ concentrations of the coarse and fine parts of the total sediment load with the concentrations associated with a characteristic size In each part, such as the median size. A review of particle-size analyses of suspended sediment at Vancouver (Haushild, $1966, p$, 151) suggests that the median sizes of the coarse and fine sediment in transport are slightly larger than 0.125 and $0.008 \mathrm{~mm}$, respectively. Unpublished data from size separates of bed sediment collected for mineralogical analyses 6 miles below the confluence of the Columbia and Willamette Rivers show that concentrations of ${ }^{65} \mathrm{Zn}$ are about 15 and $44 \mathrm{pc} / \mathrm{g}$, respectively, for these median sizes. Interpolation and extrapolation at mile 60 on the graphs in figure 28 give concentrations of 
about 40 and $200 \mathrm{pc} / \mathrm{g}$ for the median sizes, respective1y. Comparable concentrations from figure 27 are about 24 and $170 \mathrm{pc} / \mathrm{g}$. Although values of "b" computed from each pair of concentrations differ, an average ratio of about five appears to be reasonable.

Based on the findings of Johnson, Cutsha11, and Osterberg (1967), approximately 3 percent of the ${ }^{65} \mathrm{Zn}$ associated with the fine particulate matter might be displaced in the presence of sea water. Assuming this is the case, c (p. 98) equals 0.97 . If the leached ${ }^{65} \mathrm{Zn}$ remained in solution, then $k$ (p. 98) should equal about 1.15 because the ${ }^{65} \mathrm{Zn}$ associated with the particulate matter in transport is about five times greater than that in solution.

The factor $\lambda_{A}$ equals 5.82 curies per day and comes directly from the product of 0.00283 day $^{-1}$ (the decay coefficient of ${ }^{65} \mathrm{Zn}$ ) and 2,059 curies (the amount of ${ }^{65} \mathrm{Zn}$ computed to be in the estuary bed). 


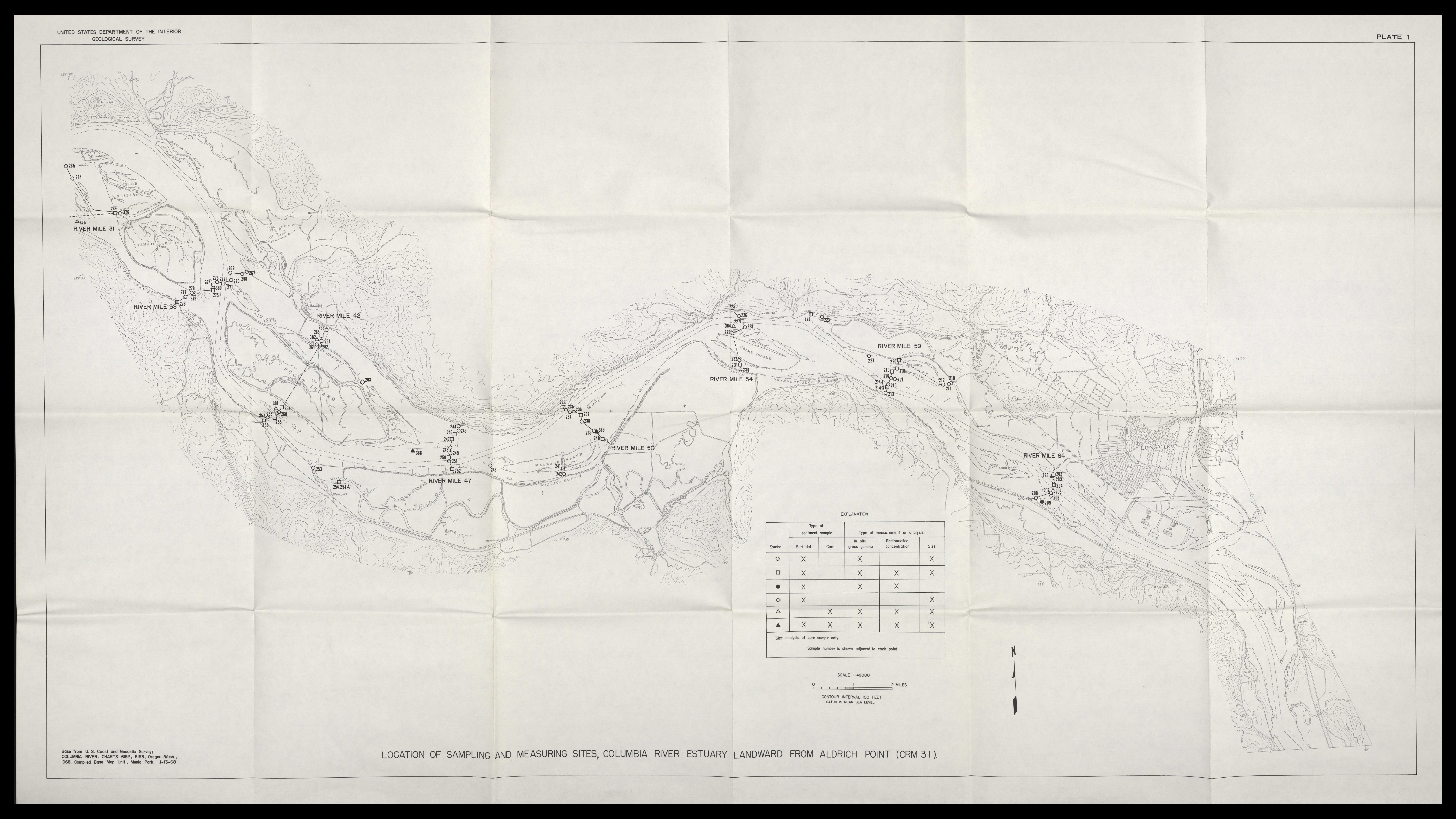





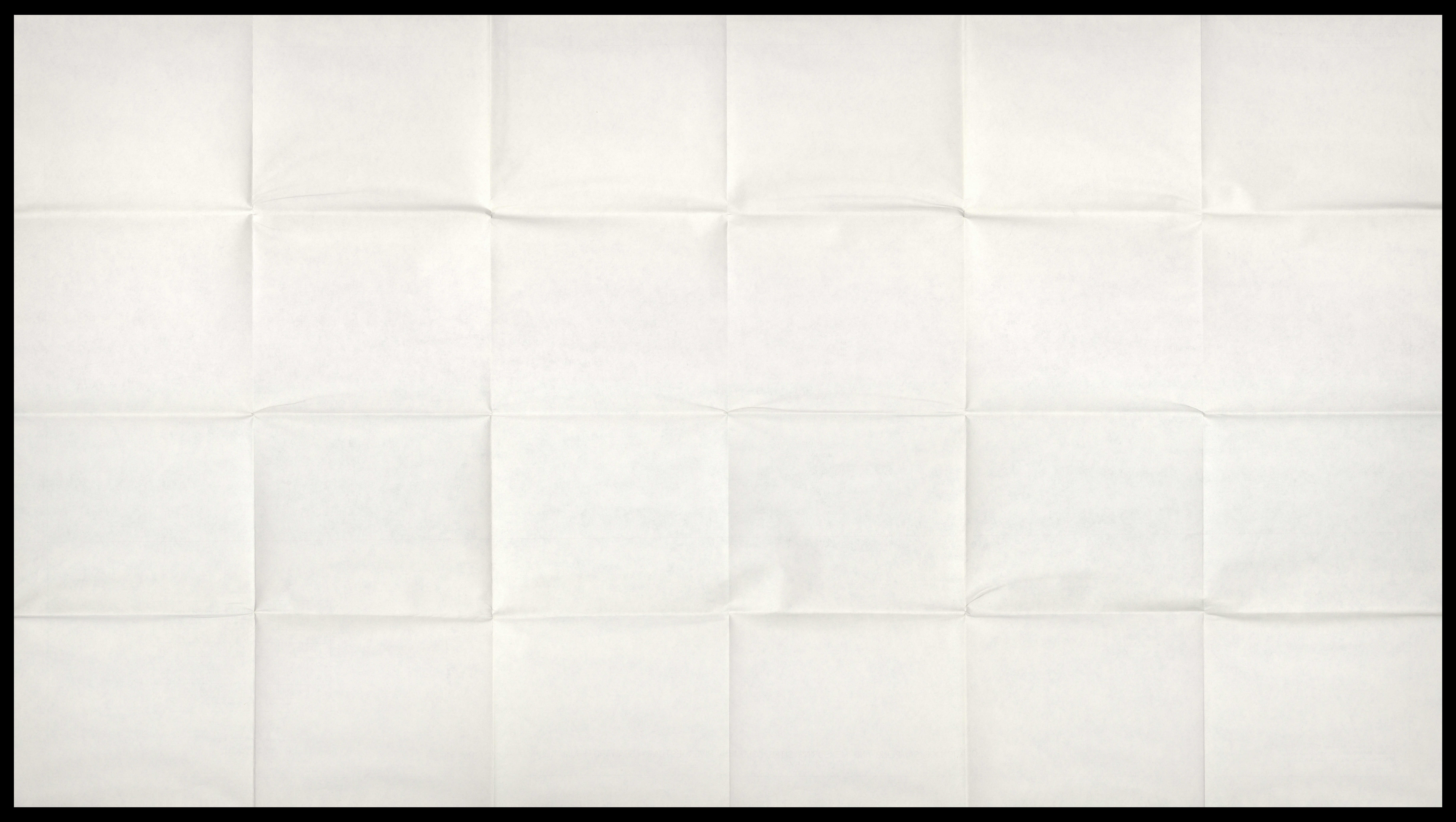

